UNIVERSIDADE DE SÃO PAULO

ESCOLA DE COMUNICAÇÕES E ARTES

MARÍLIA BILEMJIAN GOULART

\title{
Um salve por São Paulo: \\ narrativas da cidade e da violência em três obras recentes
}

São Paulo

2014 


\section{Um salve por São Paulo: narrativas da cidade e da violência em três obras recentes}

Dissertação apresentada à Escola de Comunicações e Artes da Universidade de São Paulo para obtenção do título de Mestre em Meios e Processos Audiovisuais

Área de Concentração: História, Teoria e Crítica

Orientadora: Prof ${ }^{a}$ Dra Esther Império Hamburger

São Paulo 
Autorizo a reprodução e divulgação total ou parcial deste trabalho, por qualquer meio convencional ou eletrônico, para fins de estudo e pesquisa, desde que citada a fonte.

Catalogação na Publicação Serviço de Biblioteca e Documentação Escola de Comunicações e Artes da Universidade de São Paulo Dados fornecidos pelo(a) autor(a)

Goulart, Marília Bilemjian

Um salve por São Paulo: narrativas da cidade e da violência em três obras recentes / Marília Bilemjian Goulart. -- São Paulo: M. B. Goulart, 2014.

166 p.: il.

Dissertação (Mestrado) - Programa de Pós-Graduação em Meios e Processos Audiovisuais - Escola de Comunicações e Artes / Universidade de São Paulo.

Orientador: Esther Império Hamburger Bibliografia

1. Cinema 2. Violência 3. Crime 4. Ataques do PCC I. Hamburger, Esther Império II. Título. 
Nome: GOULART, Marília Bilemjian

Título: Um salve por São Paulo: narrativas da cidade e da violência em três obras recentes

Dissertação apresentada à Escola de Comunicações e Artes da Universidade de São Paulo para obtenção do título de Mestre em Meios e Processos Audiovisuais

Aprovado em:

\section{Banca Examinadora}

Prof. Dr.

Instituição: Assinatura:

Prof. Dr.

Instituição: Assinatura:

Prof. Dr.

Instituição: Assinatura: 
À Perci, Hugo e Leila (in memoriam) que cedo partiram ao longo deste processo.

À Stella e Sérgio, mãe e pai nada comuns. 


\section{Agradecimentos}

Agradeço à Fundação de Amparo à Pesquisa do Estado de São Paulo (FAPESP) pela bolsa de mestrado que permitiu minha dedicação exclusiva a esta dissertação.

Aos funcionários da USP - da equipe de limpeza, segurança, da biblioteca, da secretaria, técnicos e docentes - pelas muitas contribuições e apoios que recebi ao longo desta pesquisa. Muitos nomes me escapariam, por isso um agradecimento geral, amplo e sincero, para não cometer injustiças.

À Esther Hamburger, pela paciência, estímulo e orientação.

À Stella e Sérgio, pelas imensuráveis contribuições em todos estágios da minha vida.

A Pedro, pela ajuda e companheirismo em meio a nossa (momentânea) tortuosa rotina.

A Ricardo, que acompanhou esta trajetória desde a primeira fagulha de ideia até o último ponto do texto - e também a última imagem! Agradecer é uma atitude infinitamente pequena para a gigantesca força recebida. 
A maior parte de nós conhece e teme a tortura e a cultura do terror unicamente através das palavras dos outros. Por isso preocupo-me com a mediação do terror através da narrativa e com o problema de escrever eficazmente contra o terror. (TAUSSIG, 1993, p. 25). 


\section{Resumo}

GOULART, Marília. Um salve por São Paulo: narrativas da cidade e da violência em três obras recentes. 2014. 166 f. Dissertação (Mestrado) - Escola de Comunicações e Artes, Universidade de São Paulo, São Paulo, 2014.

Esta dissertação discute o modo como a cidade de São Paulo, marcada pelos ataques do Primeiro Comando da Capital de maio de 2006, é construída em Salve Geral (Sérgio Rezende, 2009), Inversão (Edu Felistoque, 2010) e Os Inquilinos (Sergio Bianchi, 2009). Distantes dos paradigmáticos títulos cariocas que têm abordado violência e crime nas últimas décadas e em consonância com a polifórmica São Paulo do cinema, Salve Geral, Inversão e Inquilinos constroem diferentes cidades na tela. Em suas distintas opções formais e narrativas, encontramos entre os três títulos possiblidades que escapam de um apelo sensacional do evento. De modo instigante, os três filmes inserem a cobertura dos meios de comunicação em suas diegeses, colocando em pauta as interlocuções midiáticas em torno da violência, reforçando a importância das diferentes narrativas na construção do fenômeno e sugerindo uma postura reflexiva sobre a implicação dos filmes nesse conjunto de narrativas.

Palavras-chave: cinema, crime, violência, cidade, São Paulo, ataques do PCC 


\section{Abstract}

GOULART, Marilia. Around Sao Paulo: narratives of the city and of violence through three recent movies. 2014. 166 f. Dissertação (Mestrado) - Escola de Comunicações e Artes, Universidade de São Paulo, São Paulo, 2014.

This dissertation inquiries the ways in which the city of Sao Paulo, marked by the attacks carried out by the criminal organization PCC (First Command of the Capital) in May 2006, is shown on three recent movies: Time of Fear (Salve Geral, Sérgio Resende, 2009), The Tenants - Don't Like It, Leave (Os Inquilinos, Sérgio Bianchi, 2009) and Inversão (Edu Felistoque, 2010). All three movies strengthen the multiple filmic representations of Sao Paulo, and not only differ from each other, but also when compared to recent movies that deal with urban violence, specially box-office hits shot in Rio de Janeiro like City of God (Cidade de Deus, Fernando Meirelles, 2002) and Elite Squad (Tropa de Elite, José Padilha, 2007). Through its multiple narrative and formal choices, we see among the three movies possibilities that escape a sensationalistic appeal of the event. In an interesting way the three movies not only include the attacks but also the mediatic reverberations, pointing the implication of the many narratives in the building of the phenomenon of violence and encouraging a reflective thought about is own construction.

Keywords: crime, violence, city, Sao Paulo, PCC (First Command of the Capital), attacks of PCC 


\section{Sumário}

Introdução: Ataques, crime e violência - da cidade ao cinema

Crime e violência no cinema recente

Três Salves por São Paulo: narrativas da violência

Capítulo 1. Salve Geral - o dia em que São Paulo parou

Drama, mídia: ação

Cidade-movimento: imensidão

Salve que não ressoa (ou convenção que pouco convence)

Capítulo 2. Inversão

Circum-cidade-mata

Miscelânea: clichê e experimento

Cidade-Selva

Sombras, fantasias e "realidade"

Capítulo 3. Os Inquilinos - os incomodados que se mudem

Uma narrativa do cotidiano

São Paulo-Bairro: cotidiano em conflito

o espetáculo ao lado e o espectador-personagem

Specto

Considerações Finais

Referência Bibliográfica

Referência Filmográfica 


\section{Introdução:}

\section{Ataques, crime e violência - da cidade ao cinema}

Sexta-feira, 12 de maio de 2006 - véspera do aniversário da abolição da escravatura e faltando 48 horas para o Dia das Mães. Após escutas telefônicas levantarem suspeitas de que membros do coletivo de presos Primeiro Comando da Capital (PCC) planejavam ataques contra lideranças políticas do Estado de São Paulo, 765 homens que estavam detidos em diversos presídios são transferidos para a penitenciária II de Presidente Bernardes - de segurança máxima. Segundo os detentos, além de injustificadas, as transferências foram provocativas e praticadas com requintes de crueldade ${ }^{1}$. A ação do governo teve uma reação quase que imediata. Nessa mesma tarde de sexta iniciou-se uma série de rebeliões que se alastraram para dezenas de presídios. À noite, a onda de ataques dá os primeiros sinais na Zona Leste, Zona Sul e Centro, vitimando guardas da GCM (Guarda Civil Metropolitana), da Polícia Militar e Civil. Entre bairros pobres e ricos, "a cada momento surgia a informação de uma nova ação"2 que, confirmada ou não, se cruzava com outras notícias fragmentadas sobre locais atacados, sobre mortos e feridos na capital paulista e em outros municípios ${ }^{3}$.

A onda de ataques que é abordada pelas três narrativas analisadas nesta dissertação

\footnotetext{
${ }^{1}$ Entre os elementos apontados como cruéis estão as excessivas horas no "bonde" - caminhão que realiza as penosas transferências, falta de roupa, cobertor, alimentação e condições de higiene. Marcola apud MARQUES, Adalton. 'Liderança', 'proceder' e 'igualdade': uma etnografia das relações políticas no Primeiro Comando da Capital. Etnográfica, Lisboa, v. 14, 2010, p. 328.

${ }^{2}$ CARAMANTE, André; PENTEADO, Gilmar; CREDENDIO, José; TAKAHASHI, Fábio. PCC ataca e mata policiais após transferências. Folha de São Paulo, São Paulo, 13 mai. 2006. Disponível em: <http:// acervo.folha.com.br/fsp/2006/05/13/15/>. Acesso em: 22 jun. 2014.

${ }^{3} \mathrm{O}$ indulto do Dia das mães - que liberou no dia 13/05 doze mil detentos, é apontado como um dos fatores que possibilitou a onda de ataques: BERTOLOTTO, Rodrigo. Guerra entre PCC e Estado pode se repetir, diz especialista em segurança. Uol Notícias, São Paulo, 12 mai. 2009. Disponível em: <http:// noticias.uol.com.br/cotidiano/2009/05/12/ult5772u3930.jhtm>. Acesso em: 18 ago. 2014.
} 
(Salve Geral - Sério Rezende, 2009, Inversão - Edu Felistoque, 2010 e Inquilinos - Sérgio Bianchi - 2009) configura a maior empreitada contra às forças policiais e carcerárias do Estado de São Paulo. Os ataques se inserem no complexo quadro encontrado nas metrópoles do país que, a partir dos anos 80, têm lidado com as transformações no padrão do crime e da violência urbana. Essas mudanças estão intensamente relacionadas à inserção do país na rota do tráfico ilícito de drogas e armas que configura o "crime-negócio" que, em larga escala, tem atraído e vitimado jovens em situação de pobreza e exclusão. Pouco antes dos anos 80 os centros urbanos do país assistem ao aumento generalizado de roubos e furtos (a residências, veículos e transeuntes), maior organização e incremento de práticas mais violentas no crime - com aumento de taxas de homicídios e uso de armamento com maior poder de destruição ${ }^{5}$. As mudanças se tornam expoentes nas décadas seguintes quando as cidades enfrentam um “(...) complexo dispositivo de produção da violência (...) envolvendo delinquência convencional, tráfico de drogas, grupos de extermínio, corrupção policial e de agentes penitenciários (...)" ${ }^{\prime 6}$. Saindo do âmbito jurídico, dos anos 80 para cá, a problemática se espalhou como uma das principais preocupações da população, disseminando temores e também uma série de novas estratégias de proteção e reação.

Como fenômeno social, a violência urbana, considerada aqui como parte do conjunto formado por essas mudanças no padrão do crime, alavanca rupturas simbólicas que deslancham em mudanças no uso do espaço ${ }^{7}$, como esvaziamento de ruas e disseminação de enclaves fortificados ${ }^{8}$. Além da dimensão física (que fere e vitima indivíduos), a violência

\footnotetext{
${ }^{4}$ ZALUAR, Alba. Violência e crime. In: MICELI, Sergio. O que ler na Ciência Social brasileira (1970 1995). São Paulo: Editora Sumaré/ANPOCS, 1999, p. 41.

${ }^{5}$ KANT DE LIMA, Roberto; MISSE, Michel; MIRANDA, Ana Paula. Violência, Criminalidade, Segurança Pública e Justiça no Brasil: uma bibliografia. Revista Brasileira de Informação Bibliográfica em Ciências Sociais, Rio de Janeiro, $\mathrm{n}^{\circ}$ 50, 2007, p. 49.

${ }^{6}$ Ibid., p. 50.

${ }^{7}$ JAGUARIBE, Beatriz. O choque do real: estética, mídia e cultura. Rio de Janeiro: Rocco, 2007, p. 107.

${ }^{8}$ CALDEIRA, Teresa Pires do Rio. Cidade de Muros: crime, segregação e cidadania em São Paulo. São Paulo: Editora 34, 2000, p. 11-12.
} 
urbana possui uma dimensão discursiva ou narrativa que é tão significativa quanto a física, à qual está profundamente atrelada. Nos mais diversos formatos que assume, as narrativas da violência reconstituem a significação rompida pela experiência da violência9 . No cotidiano, as falas do crime, formadas pelas conversas diárias, comentários, piadas e brincadeiras que têm o crime como tema, ao mesmo tempo em que se contrapõem à experiência de ser vítima do crime, por oferecerem uma reordenação simbólica do universo abalado, fazem também a violência proliferar. As falas do crime justificam estratégias de proteção e reação, que impõem divisões e distâncias e multiplicam as regras de evitação e exclusão. Essas falas produzem explicações simplistas e elaboram preconceitos, fazendo o medo proliferar ${ }^{10}$. Como as falas do crime, as narrativas dos meios de comunicação sobre criminalidade e violência são igualmente parte constitutiva do fenômeno: “(...) o modo como a mídia fala sobre a violência faz parte da própria realidade da violência (...)"11. Assim como as falas do crime, as narrativas dos meios de comunicação (e do audiovisual) fomentam interpretações, sentidos sociais e discursos que circulam no espaço público.

Rio de Janeiro e São Paulo, ao lado de outras metrópoles do país, assistiram ao vertiginoso aumento de crimes violentos e homicídios. Segundo o Mapa da Violência publicado em 2000, de 1989 a 1998, a cidade do Rio de Janeiro enfrentou um aumento de 180,2\% no número de óbitos por homicídio, saltando da $16^{\mathrm{a}}$ para a $5^{\mathrm{a}}$ posição no ranking das capitais com maior taxa de homicídio da população jovem (de 15 a 24 anos) ${ }^{12}$. A cidade de São Paulo, que segundo o mesmo Mapa teve um aumento da taxa de homicídios comparativamente mais modesto $(36,8 \%)$, continuou no topo do ranking de jovens mortos (passando da $7^{\mathrm{a}}$ para a $6^{\mathrm{a}}$ posição). Não apenas a quantidade, mas a qualidade do crime

\footnotetext{
${ }^{9}$ Ibid., p. 39.

$10 \mathrm{lbid}$.

${ }^{11}$ RONDELLI, Elizabeth. Imagens da violência - práticas discursivas. Tempo Social - revista de sociologia, São Paulo, v. 10, 1998, p. 149.

12 WAISELFISZ, Jacobo. Mapa da Violência II: os jovens do Brasil - juventude, violência e cidadania. Brasília: Unesco, 2000, p. 49.
} 
praticado em São Paulo mudou: o crime violento (categoria formada pelos homicídios, tentativas de homicídio, lesão corporal dolosa, estupro, tentativa de estupro, roubo e latrocínio), que representava $20 \%$ do total de crimes cometidos no início dos anos 80 , passa para $36,28 \%$ do total de crimes cometidos no ano de $1996^{13}$.

As duas cidades, que nas últimas décadas têm sido palco de diversos títulos audiovisuais sobre essa problemática urbana, têm muitas peculiaridades na configuração do crime e da violência que enfrentaram e que ainda enfrentam. Entre as diferenças, a evolução do "crime-negócio" ou "organizado", como por vezes é chamado, é um dos fatores a destacar. No Rio de Janeiro a disputa por pontos de venda de drogas entre facções (como Comando Vermelho, Terceiro Comando e Amigos dos Amigos) configura um embate constante nos morros cariocas. De modo diverso, nas últimas décadas as disputas entre facções paulistanas praticamente se extinguiram. Nascido nos presídios, o Primeiro Comando da Capital - personagem central dos ataques - adquiriu uma hegemonia dentro e fora do cárcere.

$\mathrm{O}$ surgimento do $\mathrm{PCC}^{14}$, ao lado do vertiginoso crescimento da população carcerária, (que com a política de pulverização dessa população para presídios longe dos centros urbanos não gerou impacto visual aos citadinos ${ }^{15}$ ) podem ser pensados como reflexos da mudança no padrão e aumento nos índices do crime e da violência. Entre as diversas versões que narram o surgimento do PCC a que se tornou "oficial"16 afirma que a

\footnotetext{
${ }^{13}$ CALDEIRA, Teresa Pires do Rio. Cidade de Muros: crime, segregação e cidadania em São Paulo. São Paulo: Editora 34, 2000, p. 116.

${ }^{14}$ As considerações que se seguem sobre o PCC se baseiam principalmente nas etnografias de Marques (2010) que, com sua experiência em campo investigando o "proceder" da facção, discute o depoimento de Marcola à CPI do Tráfico de Armas e de Biondi (2010) cujo trabalho de campo (feito nas visitas ao marido detido em diferentes presídios) é enriquecido com balanços de diferentes narrativas sobre a facção.

${ }^{15}$ Em 1992 a população carcerária do estado de são Paulo totalizava cerca de 52 mil presos distribuídos em 43 presídios. No final de 2002 passou para quase 110 mil detentos em cerca de 80 unidades.

BIONDI, Karina. Junto e Misturado: uma etnografia do PCC. São Paulo: Editora Terceiro Nome, 2010, p. 66-67.

${ }^{16}$ Segundo Biondi (2010), após o lançamento do livro Cobras e Lagartos, de Josmar Jozino as inúmeras
} 
facção nasceu em agosto de 1993 no Anexo da Casa de Custódia e Tratamento de Taubaté após uma briga travada em uma partida de futebol. O coletivo de presos PCC, também denominado "partido", surge como uma reação às brutalidades do Estado e também para regular as relações entre os presos, diminuindo a enorme quantidade de assassinatos entre eles $^{17}$. Os presos mencionam que, após o surgimento do PCC, o estupro, o uso de crack e a extorsão realizada pelos detentos contra detentos foram extintas, de um estado hobbesiano, no lugar da guerra de "todos contra todos" veio a união do crime ${ }^{18}$.

Entre as políticas do Primeiro Comando da Capital, a "união do crime" é um lema que se mantém mesmo após as inúmeras transformações pelas quais a facção passou. No "proceder" do PCC, isto é, nas "regras" de conduta, os conflitos entre os presos não devem ser resolvidos diretamente pelo embate físico entre os envolvidos, mas devem passar por "consultas públicas" (debates), em que os integrantes do "partido" votam pela punição ou absolvição dos envolvidos. Assim, além da inexistência de disputas entre facções (estimase que o PCC "domine" 90\% das cadeias do estado de São Paulo ${ }^{19}$ ) os debates reduziram drasticamente os homicídios em decorrência dos litígios dos criminosos nas prisões e também nas ruas. Embora as ações que compõem os ataques de maio de 2006 possam ter reverberado independentemente da capilaridade do PCC, elas sugerem à população em geral aquilo que já era conhecido pelos moradores de diversas periferias, isto é, que a presença da facção não se restringe aos presídios. Esses dois fatores que aparecem como possíveis razões para o decréscimo dos homicídios nas últimas décadas ${ }^{20}$ podem também

versões sobre data e ocasião da fundação do PCC relatados pelos seus interlocutores sofreram uma "amnésia coletiva", isto é, foram abandonadas em detrimento da "versão oficial" do livro.

${ }^{17}$ MARQUES, Adalton. 'Liderança', 'proceder' e 'igualdade': uma etnografia das relações políticas no Primeiro Comando da Capital. Etnográfica, Lisboa, v. 14, 2010, p. 321.

${ }^{18} \mathrm{Cf}$ ibid. e BIONDI, Karina. Junto e Misturado: uma etnografia do PCC. São Paulo: Editora Terceiro Nome, 2010.

${ }^{19}$ BIONDI, Karina; FELTRAN, G. S.; DIAS, C.C.N.; MANSO, Bruno Paes; MARQUES, Adalton. Um debate sobre o PCC: Entrevista com Camila Dias, Gabriel Feltran, Adalton Marques e Karina Biondi.

Revista de Antropologia Social dos Alunos do PPGAS-UFSCAR, 2009, p. 158-159.

${ }^{20}$ Ibid., p. 169-172. 
ser pensados como especificidades que, como inspirações das ficções audiovisuais, estimulam particularidades nas tramas paulistanas na comparação com os títulos cariocas - diferenças que serão comentadas a seguir.

De sua fundação para cá, o coletivo de presos oscilou entre a relativa invisibilidade e a ampla visibilidade que se demonstrou perversa. Junto da sistemática ocultação da população carcerária, por muitos anos o poder público negou o poder paralelo que ameaçava sua própria autoridade. A invisibilidade do PCC foi reforçada pela mídia que, muitas vezes, substitui o nome da facção por expressões como "uma facção criminosa que domina os presídios paulistas". De seu lado, no jogo da disputa pela visibilidade, os presos demonstram estratégias para se apropriar das brechas da transmissão "ao vivo": como através das rebeliões que coincidem com o horário dos telejornais vespertinos ${ }^{21}$. A busca pelo reconhecimento por parte das autoridades e também da mídia é explicitado quando, em uma rebelião, os detentos estenderam uma faixa com o nome da facção durante entrevista coletiva concedida pelo Secretário da Administração Prisional; com a faixa, a mídia e o poder público são constrangidas a reconhecer a existência do $\mathrm{PCC}^{22}$. Vale lembrar que a disputa pelo controle da visibilidade (ou da representação) está ligada aos mecanismos de reprodução de desigualdade ${ }^{23}$, que se torna ainda mais complexa tendo em vista os jogos entre mídia, políticos e detentos - cada qual com possiblidades de ação específicas. Aqui, quem fala o que, como e onde, literalmente, reflete a disputa pelo controle da força e reafirma a desigualdade.

Com a megarrebelião de 2001 a tarefa de ocultar a facção que mobilizou 23 mil presos que, simultaneamente, rebelaram 29 presídios se tornou impossível. De modo

\footnotetext{
${ }^{21}$ NODARI, Sandra. PCC: espetáculos promovidos nos horários de exibição dos telejornais. Revista AVAudiovisual, São Leopoldo, v. 5, 2005, p. 5-6.

${ }^{22}$ BIONDI, Karina. Junto e Misturado: uma etnografia do PCC. São Paulo: Editora Terceiro Nome, 2010, p. 72.

${ }^{23}$ Cf HAMBURGER, Esther. Políticas de Representação - Ficção e Documentários em Ônibus 174. In: MOURÃO, Dora; LABAKI, Amir. O cinema do real. São Paulo: Cosac Naify, 2005, p. 197; 215.
} 
derradeiro na disputa pela visibilidade, chegando ao evento que repercute nos três títulos analisados nesta pesquisa, em maio de 2006 a ação mais contundente da facção põe fim à invisibilidade do "partido" e mostra a enorme dimensão daquilo que silenciosamente cresceu: "o que se pensava só existir nas prisões ou nos bairros periféricos ganhou visibilidade, por meio da violência, nas regiões centrais da cidade" 24 .

Segundo Marcola (detento que foi escolhido pela mídia para ocupar o posto de líder da facção), os ataques e as rebeliões surgiram como uma reação descentralizada às provocativas transferências promovidas pelo Estado. Começou com um ligando daqui e outro de lá “(...) com os presos pedindo socorro pros bandidos que estavam na rua, e a coisa foi tomando proporções incontroláveis, justamente por não ter uma liderança (...)”25. Em uma semana, essa reação disseminada e descontrolada resultou em pelo menos 80 presídios rebelados, 300 ataques contra agentes da polícia e do sistema carcerário, contra delegacias, bases e viaturas policiais, bancos e coletivos, resultando num saldo de 90 mortos $^{26}$. Passada essa semana, as rebeliões e os ataques vão gradualmente diminuindo, mas continuarão a ser vistos ao longo de todo o ano até pelo menos o mês de agosto - quando vemos surgir a busca por uma nova estratégia por parte dos membros do PCC. As reinvindicações dos presos são pautadas pela exigência de que o Estado cumpra a Lei de Execuções Penais, o que é bastante compreensível, tendo em vista os diários abusos e constrangimentos para detentos e seus familiares, além de reações desproporcionais contra a população carcerária como a que resultou no Massacre do Carandiru - evento que é recorrentemente citado como a fagulha que provocou o nascimento da facção - e a vingança que se seguiu aos ataques de 2006 vitimando centenas de civis.

\footnotetext{
${ }^{24}$ BIONDI, Karina. Junto e Misturado: uma etnografia do PCC. São Paulo: Editora Terceiro Nome, 2010, p. 77.

${ }^{25}$ Marcola apud MARQUES, Adalton. 'Liderança', 'proceder' e 'igualdade': uma etnografia das relações políticas no Primeiro Comando da Capital. Etnográfica, Lisboa, v. 14, 2010, p. 330.

${ }^{26}$ Dados contabilizados pelo governo. Disponível em: <http://www.ssp.sp.gov.br/noticia/lenoticia. aspx?id=10109>. Acesso em: 20 set. 2013.
} 
Nesse sentido, os ataques podem ser pensados em sua dimensão performática ${ }^{27}$. Com os ataques, o conflito associado à população carcerária, população já marginalizada e que dentro do cárcere tem sua invisibilidade multiplicada, foi trazido à esfera pública. Assim como os ataques às torres gêmeas de Manhattan, com os ataques de 2006, o PCC se apropriou da mídia, mas de um modo desordenado e menos elaborado. Sem seguir as regras mais tradicionais do espetáculo e das convenções narrativas que lhe regem ${ }^{28}$, o PCC se fez ver e ouvir com rebeliões e ataques a ônibus, às forças policiais e carcerárias e através do literal sequestro de um repórter da Rede Globo. Os ataques resultaram em uma surpreendente reação do Estado, que agiu não exatamente contra as ações da facção, mas contra a população da periferia: em apenas um mês, 493 pessoas foram executadas (ao que tudo indica pela polícia e por grupos de extermínio), configurando os chamados "crimes de maio".

Em agosto de 2006, um "salve geral" (como são denominados os comunicados espalhados de modo amplo pelos detentos) faz um balanço reflexivo sobre os meses anteriores. Além do balanço, o comunicado propõe uma estratégia para se fazer notar, se fazer visível, abandonando o uso da violência que, por fim, se voltou contra eles:

Como fazer para lutar e superarmos nossas dificuldades e conquistarmos nossos direitos como presos? Usando as mesmas armas que eles usam contra nós, a propaganda da divulgação, a mídia. Vamos maciçamente nos expressar à Sociedade e mostrar esse lado esquecido e cenário de tantas injustiças e violência [...] Temos que fazer todos entender que não somos esses monstros que a mídia divulga. Precisamos urgentemente mostrar à Sociedade que

\footnotetext{
${ }^{27}$ RONDELLI, Elizabeth. Imagens da violência - práticas discursivas. Tempo Social - revista de sociologia, São Paulo, v. 10, 1998, p. 147.

${ }^{28}$ HAMBURGER, Esther. Visibilidade, visualidade e performance em 11 de setembro de 2011. In: BRASIL, André; MORETTIN, Eduardo; LISSOVSKY, Maurício. Visualidades Hoje. Salvador: EDUFBA, 2013, p. 45.
} 
somos usados pelos políticos e que só queremos o que é nosso por direito, queremos ser tratados como seres humanos e não como animais como somos tratados. (SALVE [...] 2006) ${ }^{29}$.

Todavia, os presos só conseguiram usar a "arma" da mídia mantendo a via da violência: com o sequestro do jornalista da Rede Globo a emissora aceita a exigência imposta pelo PCC para libertar o repórter e exibe vídeo realizado pela facção. Nesse vídeo, um rapaz encapuzado lê um comunicado que contém críticas ao Regime Disciplinar Diferenciado e também um pedido de mudanças no sistema carcerário para que sejam atendidos os direitos dos presos ${ }^{30}$.

Como o "salve" expressa, os ataques foram apropriados pela disputa político partidária: 2006 foi ano de eleição para esferas como governo do estado e presidência da república, e as acusações sobre vínculo entre a facção e partido político acompanharam a disputa. Os ataques também foram ampla e perversamente apropriados pela mídia que, até os dias de hoje, continua a inserir o nome da facção em diversas manchetes aparentemente à cata de polêmica ${ }^{31}$. Diferente do 11 de setembro, em São Paulo não vimos desabar um símbolo (como as torres gêmeas) nem o uso de uma estratégia que se aproxime da dos ataques de Manhattan (como o timing que permitiu as emissoras se posicionarem e transmitirem ao vivo o desmoronamento da segunda torre). De modo distinto, sobre os fragmentados ataques que atingiram policiais, delegacias, bancos e coletivos espalhados

\footnotetext{
${ }^{29}$ Este "salve geral" é citado por Biondi (2010, p. 152). A autora recebeu uma cópia do comunicado lido nas prisões em que realizou campo.

${ }^{30}$ Em agosto de 2006, o vídeo foi exibido pela Rede Globo como forma de resgate para liberar o repórter Guilherme Portanova. Gravação disponível em: <http://www.youtube.com/watch?v=enHhZ9F42Z8>. Acesso em: 20 set. 2013.

${ }^{31}$ Exemplos que apontam o ainda forte apelo da facção são manchetes como "PCC tenta influenciar STF e planeja matar Alckmin" (GODOY, M. O Estado de São Paulo, 12 out. 2013. Metrópole, p. A20); "PCC tem plano para resgate de Marcola e mais 3 líderes presos" (GODOY, M. O Estado... 27 fev. 2014. Metrópole, p. A18); a edição da Carta Capital "Exclusivo: como o PCC planeja dominar o Brasil" (5 mar. 2014); "Black Blocs prometem caos na Copa e contam com PCC" (SANT'ANNA, L. O Estado... 1 jun. 2014. Metrópole, p. A20); e o programa Conexão Repórter (SBT, 3 abr. 2014) com "uma das maiores reportagens já realizadas sobre o funcionamento do PCC".
} 
pela cidade, a mídia constitui seu espetáculo que disseminou o medo pela cidade.

Sem precedente na história da cidade, do estado e do país, a onda de ataques que marcou maio de 2006 adquiriu uma dimensão que se estendeu para além dos assaltos em si. Certamente essa foi a mais larga investida contra a segurança pública e contra o sistema carcerário até hoje vista, mas a ofensiva se potencializou e o que era um evento estilhaçado pela cidade ganhou corpo e passou a reverberar em boatos que circularam em cadeia nacional ao serem "noticiados" 32.

Como em outros eventos midiáticos, junto dos veículos impressos e online, "a TV se torna não apenas o conduíte, mas também o condutor (...) de uma larga reação que dificilmente teria existido da mesma forma se o evento não tivesse sito emoldurado pela TV" ${ }^{33}$. Mesmo sem exibir os ataques sendo cometidos, os telejornais transmitiram um contagiante senso de urgência e do "ao vivo" através das constantes reprises de VTs que exibiam coletivos em chamas e cenários com marcas dos ataques. Além das reprises, repórteres apareciam ao vivo e in loco mesmo sem nada para reportar ${ }^{34}$. Até mesmo o tradicional Jornal Nacional entrou na onda e, ao vivo, das ruas de São Paulo, Willian Bonner apresentou o programa.

Desse modo, a cobertura dos ataques integrou e compôs a experiência vivida. Em maio de 2006 quem estava na cidade de São Paulo experimentou de modo mais ou menos direto as ações do PCC e da polícia. Mas, de modo amplo, os ataques foram largamente

\footnotetext{
${ }^{32}$ Entre boatos e especulações, muitas notícias tiveram que ser corrigidas e, de modo menos acidental, ao menos uma entrevista com membros do PCC foi forjada: o programa Domingo Legal, do SBT, realizou em setembro de 2006 uma entrevista com falsos integrantes do PCC que ameaçavam políticos e apresentadores de emissoras concorrentes. Além do SBT outras emissoras também foram acusadas de veicular falsas gravações telefônicas com membros do PCC em seus telejornais.

33 STAM, Robert. The Carandiru massacre: across the mediatic spectrum. In: ANDERMANN, Jeans; BRAVO, Álvaro. New Argentine and Brazilian Cinema - reality effects. Nova lorque: Palgrave Macmillan, 2013, p. 141.

${ }^{34}$ JUNQUEIRA, Diego. O Limite da notícia - cobertura da violência em São Paulo expõe a frágil fronteira entre jornalismo e sensacionalismo. Negócios da comunicação, São Paulo, out. 2006. Disponível em: $<$ http://portaldacomunicacao.uol.com.br/graficas-livros/22/artigo202405-1.asp>. Acesso em: 19 de ago. de 2014.
} 
vividos através das reportagens e notícias que se misturavam aos boatos e burburinhos sobre rebeliões, ações violentas praticadas ou planejadas que formaram uma enxurrada de informações fragmentadas que inundou o cotidiano paulistano e que, literalmente, parou a cidade. Herdeira das prescrições ficcionais da novela, da função informativa do jornal impresso e das capacidades audiovisuais do cinema ${ }^{35}$, o telejornal, junto aos demais meios de comunicação, foi responsável por produzir um evento à parte e contribuir para a construção e manutenção do clima de medo na cidade.

O ápice da construção midiática do evento aconteceu na segunda-feira (15/05/2006) quando, mesmo após um suposto cessar fogo da facção, a cidade parou: "em pouco tempo cada região de São Paulo tinha sua própria versão para o 'toque de recolher' como (...) a explosão de um shopping, ataques às faculdades, destruição do patrimônio público, saques às lojas, atentados em aeroportos (...)"36. Com os boatos, funcionários foram dispensados, lojas fechadas, ônibus recolhidos e rodízio suspenso: a cidade literalmente parou. A atuação dos media desse dia 15 foi comparada à de Orson Welles em Guerra dos Mundos (programa de rádio transmitido em 1938 pela CBS): "a aproximação entre Welles e a onda de ataques do PCC em São Paulo não é gratuita. Aquela segunda-feira foi o dia menos violento da onda de ataques (...). Foi na segunda, porém, que São Paulo entrou em pânico"37.

Com as enormes repercussões e a intensa participação dos meios de comunicação, o evento histórico se afirma também como evento midiático em que a cobertura da mídia se tornou um fenômeno para além dos fatos. Nesse sentido, o quadro remete também à Sociedade do Espetáculo, discutida por Guy Debord ${ }^{38}$, até mesmo naquilo que parece ambíguo: se por um lado os ataques "desencarnaram", abandonaram a dimensão do

\footnotetext{
35 STAM, Robert. The Carandiru massacre: across the mediatic spectrum. Nova lorque: Palgrave Macmillan, 2013, p. 141 (tradução minha).

36 KAWAKAMI, Tatiana. Toque de recolher do PCC: do boato na web às telas da tv. 2009. Dissertação (Mestrado em Comunicação) - Faculdade Cásper Líbero, São Paulo, 2009, p. 19.

${ }^{37}$ VENCESLAU, Pedro. Medo, mentiras e video-tape. Revista Imprensa, São Paulo, no 213, jun. 2006.

38 DEBORD, Guy. A sociedade do espetáculo. Rio de Janeiro: Contraponto, 2002.
} 
mundo físico para habitar o mundo das imagens (nos VTs que se repetiam ao longo do dia criando um evento à parte do que se passava nas ruas), o mundo das imagens (ou o espetáculo) integra a própria realidade física: o terror narrado pela mídia, o espetáculo midiático, realmente parou a cidade.

\section{Crime e violência no cinema recente}

A partir dos anos 90 uma série de títulos tem se lançado na problemática do crime, principalmente às mudanças que vieram assolar as cidades nas últimas décadas. Esses filmes foram responsáveis por produzir um verdadeiro boom da violência nas telas e por configurar uma vertente que - em relação à temática - ainda demonstra força nos dias de hoje. O surgimento dessa vertente coincide com o início da chamada Retomada Cinematográfica - quando a produção nacional se distancia da cifra próxima do zero e atinge maior vitalidade ${ }^{39}$. Apesar da imprecisão do termo, pois, industrialmente, o cinema nacional nunca se consolidou para poder retomar, ocasionalmente utilizarei o termo Retomada para me referir a essa vertente que surge nos anos 90 e que aborda a violência urbana. Nesse conjunto de títulos são bastantes distintas as narrativas que se passam no Rio de Janeiro e em São Paulo, cidades que têm em comum a expressiva transformação na crescente prática do crime.

Diferente do marcante cenário oferecido pela geografia carioca, que se destaca em filmes dos anos 50 até os dias de hoje, a cidade de São Paulo, que sensibiliza fotogramas desde o precoce ano de $1891^{40}$, não apresenta traço paisagístico marcante ou fisionomias

\footnotetext{
${ }^{39}$ ORICCHIO, Luiz Zanin. Cinema de novo: um balanço crítico da retomada. São Paulo: Estação Liberdade, 2003, p. 26; 29.

${ }^{40}$ A filmagem de Paschoal Segreto (1981) parece ser a primeira realizada em solo paulistano; nela o imigrante registra as manifestações realizadas em São Paulo contra a visita o rei da Itália. A hipótese foi sugerida pelo pesquisador Máximo Barro no curso "Trajetória do Cinema Paulistano" - realizado pelo
} 
recorrentes nas narrativas fílmicas que inspira. A poliformia paulistana está presente em filmes realizados em diferentes momentos como São Paulo Sinfonia da Metrópole (Kemeny \& Lustig, 1929), O Grande Momento (Roberto Santos, 1957), São Paulo S.A. (Luís Sérgio Person, 1965), O Bandido da Luz Vermelha (Rogério Sganzerla, 1968) e Cidade Oculta (Chico Botelho, 1986) e também em produções da última década como O Invasor (Beto Branti, 2001), Carandiru (Hector Babenco, 2003) e Contra Todos (Roberto Moreira, 2004).

A diferença entre as produções de Rio de Janeiro e São Paulo passa também pela repercussão dos títulos. Filmes cariocas que se tornaram emblemáticos nessa vertente como Notícias de uma guerra particular (João Moreira Salles, 1999), Cidade de Deus (Fernando Meirelles, 2002) e Tropa de Elite (José Padilha, 2007), repercutiram no cenário internacional e ainda reverberam em outras produções lançadas no presente. Esses títulos reafirmaram também a cidade do Rio de Janeiro como cenário paradigmático das narrativas que se lançam nessa problemática urbana. De modo distinto, via de regra, além da geografia pouco marcante, a produção paulistana tem chamado menos atenção.

Na comparação entre os filmes cariocas e paulistanos, a discrepância na linguagem pode apontar um caminho para se pensar na diferença de impacto entre as narrativas abrigadas em cada uma dessas cidades. As opções formais ressoam também nas particularidades do crime e da violência praticado nas duas cidades. Diferente das constantes guerras entre as facções que disputam pontos de venda de drogas nos morros cariocas e do confronto entre traficantes e polícia - guerra que se torna ainda mais complexa com a implantação das Unidades de Polícia Pacificadora - "pacificação" tematizada em Alemão (José Eduardo Belmonte, 2014) e 5x Pacificação (Luciano Vidigal, Wagner Novais, Cadu Barcellos, 2012), em São Paulo a hegemonia do PCC configura um embate que, fora da incursão dos ataques, é mais circunspecto. No lugar da disputa realizada pela força (da bala, da faca ou por outros meios) há debates.

Centro de Pesquisa e Formação Sesc-SP - mai. e jun. 2012. 
A despeito dessa hipótese que o contexto que envolve os títulos permite elucubrar, os filmes, bem como a arte em geral, não se detêm nas estatísticas ou nos dados de pesquisas. Como uma cidade e como uma trama imaginária, não devemos tomar o filme "(...) como um documento sobre a cidade, mas sim como um documento da maneira pela qual determinados cineastas, em determinados momentos, viam e representavam a cidade" 41 . Ainda, a "arte é incontroversamente social, não tanto porque ela representa o real, mas porque ela constitui uma declaração historicamente situada, (...) elaborada por sujeitos sociais (...) profundamente imersos em circunstâncias históricas e no contingente social”42. Vale lembrar que as produções ou representações da arte reverberam nas imagens mentais que construímos da cidade e, no recorte considerado, também compõem a ampla teia de narrativas sobre a violência.

Longe de autorizar ou desautorizar a narrativa fílmica através da narrativa da ciência $^{43}$, o que interessa aqui é justamente o modo como os filmes constroem as suas narrativas como elementos verdadeiros e fundamentais para a compreensão dos significados atribuídos à vida na metrópole. Assim, a discussão sobre a produção audiovisual que aborda ataques, crime e violência não busca “(...) verificar se os fatos [que compõem as narrativas] são reais, mas em que consiste a política de sua interpretação e representação"44. Vale destacar que, ao tratar das narrativas audiovisuais, não me refiro exclusivamente à história contada/narrada, mas ao processo formado pela atividade de seleção, organização e disposição do material fílmico para alcançar efeitos específicos ${ }^{45}$.

\footnotetext{
${ }^{41}$ BERNARDET, Jean Claude. O homem na rua: cinema. Cadernos de História de São Paulo, São Paulo, $\mathrm{n}^{\circ} 1,1993$, p. 57.

${ }^{42}$ STAM, Robert. The Carandiru massacre: across the mediatic spectrum. Nova lorque: Palgrave Macmillan, 2013, p. 155 (tradução minha).

${ }^{43}$ Como a história, a produção das ciências sociais pode ser pensada como narrativa que "como o romance (...) seleciona, simplifica, organiza, faz resumir um século numa página (...)". VEYNE, Paul. Como se escreve a história. Lisboa: Edições 70, 1983, p. 14.

${ }^{44}$ TAUSSIG, Michael. Xamanismo, colonialismo e o homem selvagem: um estudo sobre o terror e a cura. Rio de Janeiro: Paz e Terra, 1993, p. 15.

${ }^{45}$ BORDWELL, David. Narration in the fiction film. Londres: Methuen, 1985, p. ix.
} 
De modo geral as divergências entre os títulos paulistanos e cariocas abarcam o tratamento estético e temático. A comparação revela também o contraste entre os espaços, os personagens e seu deslocamento na cidade que marcam as narrativas ambientadas em cada uma das metrópoles. Diferente de certo padrão presente nos títulos cariocas, que localizam a violência no morro e em torno de seus habitantes, a filmografia paulistana alarga os cenários e o leque dos personagens envolvidos nas tramas marcadas pelo crime e violência.

Fora do reduto do morro, a São Paulo dos filmes é mais heterodoxa. Sua paisagem às vezes é composta por uma topografia verticalizada (de morros ou prédios) e, com maior recorrência, por uma gigantesca extensão horizontal que se expande através de ruas, trilhos e avenidas como que ao infinito. Com paisagens centrais, edifícios modernos, marcos históricos e culturais, a capital paulista dos filmes também é composta por construções decadentes e desconhecidas e por cenários periféricos. A periferia mantém a tônica da pluralidade e expressa a diversidade entre ruas asfaltadas e de terra batida, autoconstruções, casas precárias e sem acabamento que estão próximas de lares caprichados e aconchegantes. Os diferentes espaços, vistos de longe, de dentro, de baixo e do alto; da moto, do carro, do trem e do ônibus, reafirmam o cenário múltiplo da cidade partida - que diferentemente dos morros cariocas que cercam as áreas ricas e centrais, se divide e se parte através dos enclaves fortificados e da concentração de serviços em algumas regiões e escassez em outras.

Muitas vezes essas diversas faces da cidade aparecem em um único filme, mas também surgem na comparação entre diferentes títulos, inclusive naqueles que utilizam o mesmo bairro como locação. A Brasilândia de Eles não usam black tie (Leon Hirszman, 1981) é cenário recorrente nessa vertente que aborda violência e crime nas cidades das últimas décadas. Em cada título a Brasilândia aparece com características diferentes, como a topografia horizontal de Contra Todos (Roberto Moreira, 2004) que contrasta com os morros, mais ou menos imponentes, vistos em Os Inquilinos (Sérgio Bianchi, 2009), Antônia 
(Tata Amaral, 2006) e O Invasor (Beto Branti, 2001).

Nessa multiplicidade de espaços o trânsito dos personagens pela cidade é uma característica que atravessa diversos filmes e que marca os três títulos desta pesquisa. Com espaços públicos que raramente aparecem com outro uso que não de passagem, a São Paulo é construída em muitas narrativas como um arquipélago, isto é, uma cidade composta por um território fragmentado onde o deslocamento se dá entre as ilhas (espaços privados) que funcionam como redutos da segurança ${ }^{46}$. Até mesmo em narrativas fortemente conectadas a um bairro - como Contra Todos, Antônia, Inquilinos e Bróder (Jeferson De, 2012) os personagens se deslocam com constância. De modo extremo, em filmes como Os 12 trabalhos (Ricardo Elias, 2007), De Passagem (Ricardo Elias, 2003), Linha de Passe (Walter Salles e Daniela Thomas, 2008) e Inversão (Edu Felistoque, 2010), o trânsito dos personagens é tão intenso que parece conduzir as tramas.

As narrativas paulistanas não se centram apenas em personagens masculinos, jovens negros moradores das favelas. Os filmes sobre crime e violência que se passam em São Paulo incluem pobres e marginalizados: Onde São Paulo Acaba (Andréa Seligmann, 1995), Um Céu de Estrelas (Tata Amaral, 1996), De Passagem, Antônia e Bróder, mas também da classe média/alta: Inversão, O Invasor, Salve Geral (Sérgio Resende, 2009) e Dois Coelhos (Afonso Poyart, 2012). Apesar de larga, a escolha por não se centrar no drama dos pobres não é exclusiva dessa vertente, mas marca títulos paulistanos de outras décadas, como os de Walter Hugo Khoury que expressam o drama da elite que, apesar das boas condições de vida, vivem e se relacionam mal.

Vemos também nas narrativas paulistanas uma maior presença de famílias nucleares e de mulheres que aparecem em diversos títulos situados em São Paulo como protagonistas.

\footnotetext{
${ }^{46}$ A noção de cidade-arquipélago é desenvolvida através da análise de $O$ Invasor pensada em contraponto à cidade-máquina dos anos 60 de São Paulo S.A.. XAVIER, Ismail. São Paulo no cinema: da coesão da cidade-máquina à corrosão da cidade-arquipélago. Sinopse: Revista de Cinema, São Paulo, v. 11, 2006b.
} 
Sérgio Rezende, realizador carioca, declara que, durante sua pesquisa para Salve Geral, se impressionou com tantas figuras femininas que exercem forte papel no universo do crime. Com sua descoberta o diretor decide "(...) construir o filme em torno dessas mulheres, personagens inéditos em nossa dramaturgia" 47.

As muitas imagens de São Paulo presente nos títulos dessa filmografia podem ser pensadas em paralelo ao que se passa com a cidade física que, seguindo o ritmo do capital privado se move numa engrenagem de eterna renovação, vai se destruindo e reconstruindo, reforçando continuamente sua paisagem que abriga extremos contrastes. Comandada pela especulação imobiliária que se impõe sobre a própria noção de cidade, numa dominação prepotente, dinâmica e feroz que a transforma sem parar "em ruidoso construir-destruir ela é para todo brasileiro, nas palavras de Caetano Veloso, 'o avesso do avesso do avesso' "48. Esse constante destruir-construir, conforme o "mil vezes recomeçar" de Carlos de São Paulo S.A., faz com que a experiência do cineasta se aproxime da do bandeirante, desbravando esses espaços sempre novos ${ }^{49}$. Mesmo quando debruçados sobre "o mesmo" (como nos filmes analisados neste trabalho, que se situam na cidade de São Paulo no ano de 2006), o espaço urbano paulistano mantém sua multiplicidade, ou melhor, sua "particular tradição do não-tradicional" ${ }^{50}$.

A diversidade de classes e "tipos" presente nos filmes se conecta também com a pluralidade da metrópole cuja representação seria pouco convincente se centrada em um único núcleo, seja o nicho do luxo, seja o do lixo. Em sua variedade de perfis, os personagens circulam através dos mais diversos meios que vão do carro importado ao trem, percorrendo os "vários mundos" de São Paulo. As recorrentes imagens de trânsito encontram eco na

\footnotetext{
${ }^{47}$ REZENDE, Sérgio \& ANDRADE, Patrícia. Salve Geral. São Paulo: Imprensa Oficial, 2009, p. 13 (grifo meu).

${ }^{48}$ MACHADO, Jr., Rubens L. R. São Paulo, uma imagem que não pára. Revista D'Art, São Paulo, nº 9/10, 2002, p. 60.

49 Ibid. Idem.

${ }^{50}$ Ibid. Idem.
} 
configuração dessa megacidade partida: com “(...) arranha-céus, escritórios high-tech e favelas, metrôs sofisticados e altas taxas de mortalidade infantil (...) São Paulo tornou-se um dos melhores símbolos de consumo industrial pobre, mas moderna, heterogênea e profundamente desigual" ${ }^{51}$. Extremamente excludente, a cidade ao concentrar riquezas e distribuir precariedade constrói uma “(...) 'ditadura do movimento' no cotidiano da população que utiliza ou frui a cidade, a partir de um ir e vir constante de carros, ônibus, metrôs, vans, trens, pés, carroças. Estar em São Paulo é estar sempre indo ou voltando para/de algum lugar" 52 . Da mesma forma, como veremos, os três títulos apresentam cenários bastante diversos, do bairro periférico ao centro, a cidade é marcada também pelos espaços exclusivos ao trânsito (como grandes avenidas como a 23 de Maio e o Viaduto do Anhangabaú). Além do trânsito intenso que marca os três títulos, duas das narrativas que serão analisadas nesta pesquisa não se restringirão aos limites da cidade, e suas tramas nos levam também ao Paraná e à mata (Salve Geral e Inversão).

A filmografia que tem São Paulo como cenário se diferencia da linguagem que marca as obras cariocas de maior repercussão. As narrativas paulistanas parecem oferecer um espetáculo menos vibrante e não apresentam muitas semelhanças com a linguagem encabeçada por Cidade de Deus, que influenciou outros filmes de sucesso, como Tropa de Elite. Essa linguagem é marcada pelo intenso trabalho sobre as cores na pós-produção (alterando saturações e temperaturas) e pela montagem fragmentada que articula curtos e instáveis planos captados pela câmera na mão. Essa câmera mais solta, que foi lema do Cinema Novo ("uma ideia na cabeça e uma câmera na mão"), não tem nada a ver com a proposta de sinalizar através dos elementos estéticos as condições de filmagem e do país. Longe disso, a câmera na mão nas ficções dessa vertente da Retomada abandona a alegoria e passa a assumir um significado mais literal.

\footnotetext{
${ }^{51}$ CALDEIRA, Teresa Pires do Rio. Cidade de Muros: crime, segregação e cidadania em São Paulo. São Paulo: Editora 34, 2000, p. 48.

${ }^{52}$ ROLNIK, Raquel. São Paulo. São Paulo: Publifolha, 2001, p. 77-76.
} 
No conjunto de títulos da última década, via de regra, o balançar intenso e a instabilidade da imagem (que são produzidos pela câmera na mão e também pela montagem) simulam a intensidade da tomada, ou mais precisamente, o embate na circunstância da tomada e a postura do sujeito-câmera ${ }^{53}$ que, em coerência com a situação, não tem espaço para se preocupar com o foco ou com a estabilidade da imagem. Essa câmera trêmula que, pelo menos desde a cobertura da Segunda Guerra Mundial, se tornou sinônimo de uma tomada real, não mediada ou ensaiada ${ }^{54}$, remete ao estilo do programa Aqui Agora (1990) e opera como um índice da aventura e do real perigo da gravação in loco.

\section{Três Salves por São Paulo: narrativas da violência}

A pluralidade de cenários e personagens paulistanos se mantém nos três títulos analisados nesta pesquisa: Salve Geral, Inversão e Os Inquilinos apontam para diferentes tratamentos do urbano e dos ataques do PCC que, junto de seus personagens, adquirem sentidos específicos em cada trama. Nos três filmes os ataques aparecem respectivamente como elemento climático e central da história, ponto de partida do qual a narrativa se distancia e também como o drama que permeia o cotidiano dos personagens durante o decorrer da trama. Em cada um dos filmes, figuras arquetípicas da vida urbana contemporânea como o trabalhador, a classe média, o empresário, o bandido e a polícia se entrelaçam de maneira a construir certas São Paulo(s). Essa pluralidade permite a discussão sobre as diferentes formas como o cinema (re)elabora os ataques, construções que nem sempre passarão pelo espetáculo. Se a colagem nesse evento de ampla repercussão

\footnotetext{
${ }^{53}$ Sobre a intensidade da tomada e o sujeito-câmera ver RAMOS, Fernão. Cinema e Realidade: alguns aspectos estruturais da imagem-câmera e sua particular intensidade. In: XAVIER, Ismail. O cinema do Século. Rio de Janeiro: Imago, 1996.

${ }^{54}$ WINSTON, Brian. A maldição do 'jornalístico' na era digital. In: MOURÃO, Dora; LABAKI, Amir. O cinema do real. São Paulo: Cosac Naify, 2005, p. 17.
} 
pode sugerir o desejo de embarcar na visibilidade dos ataques, esse hipotético anseio aqui elucubrado não se consumou. Diferente do que se passou com os ataques - e mantendo certa consonância com a filmografia paulistana, os três títulos repercutiram de forma discreta.

As multiplicidades que o estudo comparativo traz à tona ecoa na pluralidade da cidade e de seus habitantes que foram tocados e que tocaram de diferentes formas os ataques. Narrativa de ação, linguagem que flerta com o experimental e poética que remete ao cinema moderno: através dessas formas o corpus analisado constrói múltiplos pontos de vista sobre a São Paulo que esteve sob ataques em maio de 2006.

De modo interessante, veremos nos três filmes não apenas os ataques (e outros crimes) serem cometidos no interior da trama, mas também a cobertura midiática dessas ações que aparecem com força nas três diegeses. Vale lembrar que a presença dos media nas ficções recentes que abordam a violência e o crime não é rara e surge em títulos como Um céu de estrelas (Tata Amaral, 1996), Como nascem os anjos (Murilo Salles, 1997), Cidade de Deus (Fernando Meirelles, 2002), Tropa de Elite 2: o inimigo agora é outro (José Padilha, 2010) e também em Ônibus 174 (José Padilha, 2002) - documentário que, como os três títulos analisados aqui aborda um evento de ampla visibilidade midiática e, na comparação com o evento, repercutiu pouco.

Ao inserir os discursos midiáticos em suas tramas, Salve Geral, Inversão e Inquilinos lançam luz sobre um importante aspecto na dinâmica crime/violência-cidade: as narrativas do crime e da violência que, além das falas do crime, abarcam as diversas narrativas audiovisuais, dos media ao cinema. Essas narrativas, conjunto no qual os próprios filmes se inserem, se apresentam como elemento sumamente responsável pelo nosso contato diário com a criminalidade e com a violência. Além disso, as narrativas são também parte constitutiva do próprio fenômeno da violência. Ao incorporar, de modo mimético ou crítico, outras narrativas em sua composição, os três títulos encorajam uma (auto)reflexão 
sobre o seu modo de narrar filmicamente a violência. Como veremos nos capítulos específicos, a tríade cidade, crime/violência e mídia nem sempre resulta no espetacular ou no sensacional, mas será também potente na produção da crítica.

Em Salve Geral acompanhamos Lúcia e Rafa, mãe e filho que compõe uma família de classe média que enfrenta o agravamento de sua decadência financeira após a prisão de Rafa. Com a detenção, nos aproximamos, junto com os personagens, do universo do PCC dentro e fora das cadeias, onde eles se envolverão com os membros do "partido" ao lado dos quais Rafa atuará nos ataques. Das três tramas essa é a que mais se concentra nos ataques que surgem na metade final da narrativa, agravando conflitos e motivando o giro final. Salve Geral é construído através da estrutura narrativa e decupagem mais clássicas, que no campo da linguagem se combina com o estilo do filme de ação de Hollywood e também com uma estética que remete à cobertura jornalística. $\mathrm{O}$ intenso trânsito dos personagens marca o desenvolvimento da narrativa e constrói uma São Paulo formada por "cartões postais" (Banespinha, Anhangabaú e Avenida Paulista) que se misturam à multiplicidade de espaços mais "anônimos" ("Jardim Copacabana" - bairro fictício e São Rafael).

De modo distinto, Inversão é marcada por alguns clichês (da narrativa policial e do filme noir) e por propostas formais levadas ao extremo, como a literal inversão da imagem do filme, que sugere sua vinculação com o cinema experimental. Em Inversão os ataques apenas pontuam o início da trama, motivando uma mudança na rotina de Carlão, policialnarrador que passa a ajudar a Delegada Juliana na investigação do sequestro que conduz a narrativa. Longe da colagem no evento anunciado nos primeiros minutos do filme e da reiteração do real (exaltado pela trilha e pelo off), o experimento da linguagem e parte da pouca sutileza configuram um interessante comentário acerca do urbano e sobre as relações na cidade. Se os ataques têm pouco destaque ao longo da trama, eles são importantes pra constituir a barbárie e o clima literalmente noir da cidade que é enfatizado com sons e 
imagens. Tanto a busca para resolver o caso, quanto o sequestro não são bem-sucedidos. Em paralelo aos sequestradores que se veem presos na mata, acompanhamos os policiais em uma busca desesperançosa na cidade, aprisionados em um deslocamento contínuo por espaços que se repetem e que não apontam saídas ou soluções. Como os personagens, a São Paulo de Inversão (composta pela periferia e por locais mais centrais como as avenidas 23 de maio, Vergueiro e 9 de Julho) é "feia, suja e má".

Colado na rotina de Valter ao lado da esposa Iara e dos filhos Fernanda e Diogo, Inquilinos é construído com um ritmo mais vagaroso e uma linguagem marcada por uma poética do cotidiano. Apesar do constante trânsito diário entre casa, trabalho e escola nos extremos da cidade, a São Paulo de Inquilinos é centrada no bairro periférico (locação da Brasilândia que aparece como uma paisagem "qualquer"). Além do Ceasa, local de trabalho que pode ser reconhecido na tela, aqui não há imagens paradigmáticas de São Paulo. Sob a aparente harmonia do bairro o conflito latente na vizinhança é expresso e exponenciado com a chegada dos jovens e barulhentos inquilinos. No cotidiano que se expressa também pelas imagens e ritmo da trama, Valter vaga em meio aos ataques e membros do "partido" sempre acompanhado pelas notícias, boatos e especulações sobre casos e temores de violência que, vez ou outra, se confirmam.

Em cada uma dessas três construções fílmicas, o crime e a violência (praticada, narrada, imaginada, etc.) surgem de formas bastante singulares. Além das diferentes São Paulo(s) construídas e dos personagens articulados, no campo da linguagem, chama a atenção o modo como a violência é desenvolvida em cada um dos longas. No cinema "são muitas as estéticas da violência, com diferentes éticas e consequências: afirmativas, reativas, resistentes elas podem ser sintoma e expressão de formas de viver, valorar e pensar" 55 , podendo ser trabalhadas como um dos recursos a desarticular ou a reforçar

\footnotetext{
${ }^{55}$ BENTES, Ivana. Estéticas da Violência no Cinema. Interseções: Revista de Estudos interdisciplinares, Rio de Janeiro, ano 5, 2003. Edição especial, p. 8.
} 
estereótipos, encaminhar leituras que naturalizem ou que problematizem e questionem as ações mostradas. As opções nas construções fílmicas colocam em pauta também a questão de como tratar de temas sangrentos sem reproduzir o sensacionalismo.

As cenas de agressão podem ser construídas de modo gráfico, através da imagemviolência em que a ação violenta é construída com imagens literais da violência praticada (a chamada "violência explícita") e também com recursos estilísticos em que a linguagem é considerada violenta (como a montagem rápida e fragmentada e a câmera instável) ${ }^{56}$. Por outro lado, diferente da violência sensorial, as cenas de agressão podem ser construídas através de recursos da montagem e da composição do quadro que sugerem a ação, como em cenas de Os Fuzis (Rui Guerra, 1964) e ainda em opções singulares, como a tela preta de Ato dos Homens (Kiko Goifman, 2006). As opções atreladas à sugestão ou à construção sensorial da violência não indicam os significados que serão produzidos; ambas podem ser usadas para reforçar ou desconstruir preconceitos relacionados à violência. Sem pressupostos de antemão sobre a linguagem, interessa a esta pesquisa investigar quais são os modos como se narra a violência.

Em Salve Geral as ações violentas aparecem através de imagens literais em sequências que são, muitas vezes, fervilhantes nos moldes do filme de ação. Em Inversão, nas cenas de agressão, predomina um tratamento que não endossa a ação e que, através do experimento no campo da linguagem, traz à tona o tormento do ato. De modo bastante peculiar, Inquilinos explicita a ausência de imagens literais das ações violentas, formando um espectro, isto é, uma massa que - sem se atualizar em imagens literais da agressão segue Valter nos mais diversos espaços. Dessa ausência emerge com potência esse espectro da violência que ganha força e permanece ao longo de toda a narrativa. Além de vitimar

\footnotetext{
${ }^{56}$ HIKIJI, Rose. Imagem-Violência: mímesis e reflexividade em alguns filmes recentes. 1998. Dissertação (Mestrado em Antropologia) - PPGAS-FFLCH. Universidade de São Paulo, São Paulo, 1999. Hikiji (1999) discute a presença da violência não apenas como tema, mas na própria forma, como "imagemviolência". Parece haver poucos casos nas narrativas pós-retomada que lidam com violência urbana que se afastem das "imagens-violência".
} 
personagens que rodeiam a família de Valter, o espectro é eficiente na construção do clima sufocante que se espalha por todos os lados, cresce e se torna insuportável.

As diferenças entre os três títulos sugerem uma proximidade com as distinções entre um cinema de ação e um cinema de "vidência" propostas por Deleuze através das definições de imagem-ação e imagem-tempo - inspiradas na elaboração de Bazin sobre um cinema atento aos planos-sequência, a profundidade de campo e a filmagem em locação ${ }^{57}$. $\mathrm{Na}$ passagem da imagem-ação para imagem-tempo - que, segundo Deleuze, é uma evolução rumo às imagens puramente óticas e sonoras $^{58}$, ocorre o declínio do esquema sensório-motor (isto é, o esquema estruturado entre ação-reação). Assim, "diferente de um fio condutor ou da forte conexão que ligava os acontecimentos uns aos outros no cinema de ação, as ligações, os encadeamentos entre as imagens se tornam agora fracos, aparecem agora enfraquecidos, como se existissem por acaso" $" 59$.

$\mathrm{Na}$ análise dos três filmes passaremos da narrativa que segue um modelo mais clássico atrelado ao esquema sensório-motor da imagem-ação, onde os ataques são o cerne da trama (Salve Geral), a um que lança mão de experimentos e construções inusitadas em uma cidade amarelada e doentia onde os ataques ajudam a construir seu literal clima noir (Inversão). E por último, a narrativa que se aproxima do cinema moderno (ou "cinema de vidente" da imagem-tempo), onde os personagens assistem aquilo que se passa à sua volta (Inquilinos). No conjunto das análises, veremos assim diferentes sentidos para o urbano e múltiplas interpretações do evento e da vida na cidade sob ataques.

Bastante distinto do sentido que a palavra "salve" possui no dialeto dos detentos que, possivelmente, com o "salve geral" espalharam os ataques pela cidade, a gíria popular

\footnotetext{
57 BAZIN, André. A evolução da linguagem cinematográfica. In: O cinema: ensaios. São Paulo: Brasiliense, 1991.

58 DELEUZE, Gilles. Para além da imagem-movimento. In: Cinema 2: A imagem-tempo. São Paulo: Brasiliense, 1990.

${ }^{59}$ MACHADO, Roberto. Deleuze e a crise do cinema clássico. In: PESSOA, Fernando; BARBOSA, Ronaldo. Do abismo às montanhas. Vitória: Fundação Vale, 2010, p. 205.
} 
"salve" significa tanto uma saudação quanto uma indicação de aproximação, de encontro. Nesse sentido coloquial, cada um dos filmes "dá um salve" à cidade, vai a seu encontro. Através desses diferentes encontros esta dissertação busca discutir os modos como a cidade, marcada pelo "salve" do crime e da violência é percebida, imaginada e temida, ao menos, no campo audiovisual. 


\section{Capítulo 1}

\section{Salve Geral - o dia em que São Paulo parou}

Lançado em outubro de 2009, esse é o primeiro dos longas abordados neste estudo que faz referências aos ataques do PCC e, do trio de filmes analisados, é o que mais se centraliza na organização dos criminosos e nos lances cometidos. Diferente de Inversão que, como veremos, parte dos ataques para então se afastar deles, aqui as ações do PCC serão parte constitutiva e central da trama. Sérgio Rezende, que assina a direção e o roteiro, acumula em sua filmografia experiência com biografias de personalidades nacionais e defende que "o nosso cinema é mais forte quando fala da própria realidade" acompanhar os ataques através da cobertura da Rede Globo, o diretor decidiu filmar o que denominou "11 de setembro de São Paulo"2. A pesquisa para a elaboração do roteiro incluiu entrevistas realizadas junto da corroteirista Patrícia Andrade com agentes policiais, jornalistas e promotores, além da consulta ao farto material de imprensa ${ }^{3}$. Esse não é um filme-denúncia, nos alerta Rezende, que enfatiza ainda que, durante o processo de pesquisa para o roteiro, não teve nenhum contato com os criminosos ${ }^{4}$ - precaução que pode ter levado em conta as complicações enfrentadas por João Moreira Salles por ter se aproximado do traficante Marcinho VP. Como veremos a precaução de Rezende se reflete no filme: apesar de focar o universo carcerário, um certo distanciamento marca a relação com esse meio que é bastante pautada pelo olhar da classe média.

\footnotetext{
${ }^{1}$ Disponível em: <http://www.rua.ufscar.br/site/?p=1587>. Acesso em: 25 jul. 2013.

2 "Guardadas as devidas proporções, foi o 11 de setembro de São Paulo". Disponível em: <http://g1.globo.com/Noticias/Cinema/0,,MUL925243-7086,00-CINEASTA+DIZ+QUE+VAI+FILMAR+O +DE+SETEMBRO+DE+SAO+PAULO.html>. Acesso em: 10 jun. 2014.

${ }^{3}$ REZENDE, Sérgio \& ANDRADE, Patrícia. Salve Geral. São Paulo: Imprensa Oficial, 2009.

${ }^{4}$ Reportagem do portal G1 - citada na nota 2 deste capítulo.
} 
Ao inserir a classe média na trama, Salve Geral se esquiva do recorte centrado em personagens marginalizados que marca a filmografia carioca. Como em Inversão, aqui também "está tudo dominado", pois o crime não respeita as fronteiras sociais, é praticado por pobres, por aqueles com maior poder econômico e também por policiais. Mas as classes não aparecem do mesmo modo: ao aproximá-las em situações em que interagem, vemos reproduzida a lógica dos privilégios em relações desiguais entre classe média e presos. A desigualdade desponta tanto nas ações da narrativa (isto é, nos privilégios de Lúcia e Rafa no decorrer da trama), quanto na abordagem do filme que, tendo Lúcia como personagem central, se cola no seu ponto de vista e nos convida a nos identificarmos com ela.

Em sua construção, Salve Geral se aproxima bastante dos preceitos clássicos, tanto no desenvolvimento da narrativa quanto na linguagem. No campo da linguagem, o estilo clássico ora aparece com a decupagem e montagem mais estáveis, ora com a instabilidade que remete aos filmes de ação nos moldes de Hollywood ${ }^{5}$ que, em sua instabilidade fervilhante, marca as convenções do espetáculo. Além dos preceitos clássicos, Salve Geral articula também a cobertura midiática que aparece através das imagens de arquivos e encenações que emulam a aparência do arquivo. Além da linguagem e da trama construídas, Salve Geral se distancia bastante de Inversão e Inquilinos pelo esquema da grande produção que articula em larga escala figurantes, cenários, locações, pesado maquinário cinematográfico e efeitos especiais usados nas cenas de ação. Coproduzido pela Globo Filmes e Toscana Audiovisual, e distribuído pela Sony Pictures e Downtown Filmes, Salve Geral foi escolhido para representar o país no Oscar de 2010. O longa tem no elenco atores globais (como Andrea Beltrão, Bruno Perillo e Juliano Cazarré), do teatro (Denise Weinberg, Lee Thalor

\footnotetext{
${ }^{5}$ A seguir serão discutidas as especificidades do filme de ação através da análise de Bordwell (2008) acerca dos filmes de Hollywood. Apesar de Bordwell diferenciar cinema de ação de Hollywood e cinema de ação de Hong Kong, a partir desse trecho não será feita mais referência a Hollywood quando tratar do cinema de ação, pois, como gênero, o cinema de ação se insere no modelo clássico da indústria de Hollywood. Todavia, dentro da indústria cinematográfica dos EUA há uma diferenciação na decupagem e na montagem que será comentada a seguir.
} 
e Giulio Lopes) e, na equipe, nomes como o produtor Joaquim Vaz de Carvalho e o músico Miguel Briamonte - que compôs e gravou a trilha original com uma orquestra.

Mesmo com a forte estrutura de produção e tendo a Globo Filmes como coprodutora, que basicamente se encarrega de promover e divulgar o filme em sua grade de programação, o longa não repercutiu, seja em termos de público ou crítica. Salve Geral produziu debates apenas em torno de seu lançamento como rememoração do dia em que São Paulo parou pela ação de um estado ou poder paralelo (como o PCC é por vezes evocado pela mídia) ${ }^{6}$ e na indicação ao Oscar. Talvez pela excessiva colagem no evento que inspira o filme - evento esse que pode ter sido esgotado pela larga cobertura midiática que recebeu -, estabelecendo uma relação que é pautada especialmente pelos fatos noticiados e por esse olhar marcadamente de fora, o filme não produziu maiores diálogos com a crítica, com o público ou com outras produções.

Drama, mídia: ação

Em Salve Geral acompanhamos Lúcia e Rafa - mãe e filho que constituem uma família de classe média, no início alheia ao universo do crime e da violência, mas cujo processo de decadência será acirrado com a prisão de Rafa. O filme se inicia com a mudança do apartamento na região central que, com sua fachada modernista remete à cidade em sua melhor forma, para uma casa no "Jardim Copacabana" - bairro da periferia ficcionado no longa. Nos primeiros planos o declínio da família é expresso de forma física com a descida do piano que é retirado do apartamento. Através dos quadros extremamente ritmados que seguem o eixo vertical da corda, grade, prédio, janela, olhar, mãos e piano, é

\footnotetext{
${ }^{6}$ Como nas reportagens disponíveis em <http://terramagazine.terra.com.br/interna/0,,Ol1004801El6578,00-Vou+te+matar+diz+Marcola+ao+chefe+do+DEIC.html $>$ e $<$ http://www.revistaforum.com.br/ blog/2013/10/ok-a-policia-o-pcc-e-um-modelo-de-seguranca-publica-falido/>. Acesso em: 19 ago. 2014.
} 

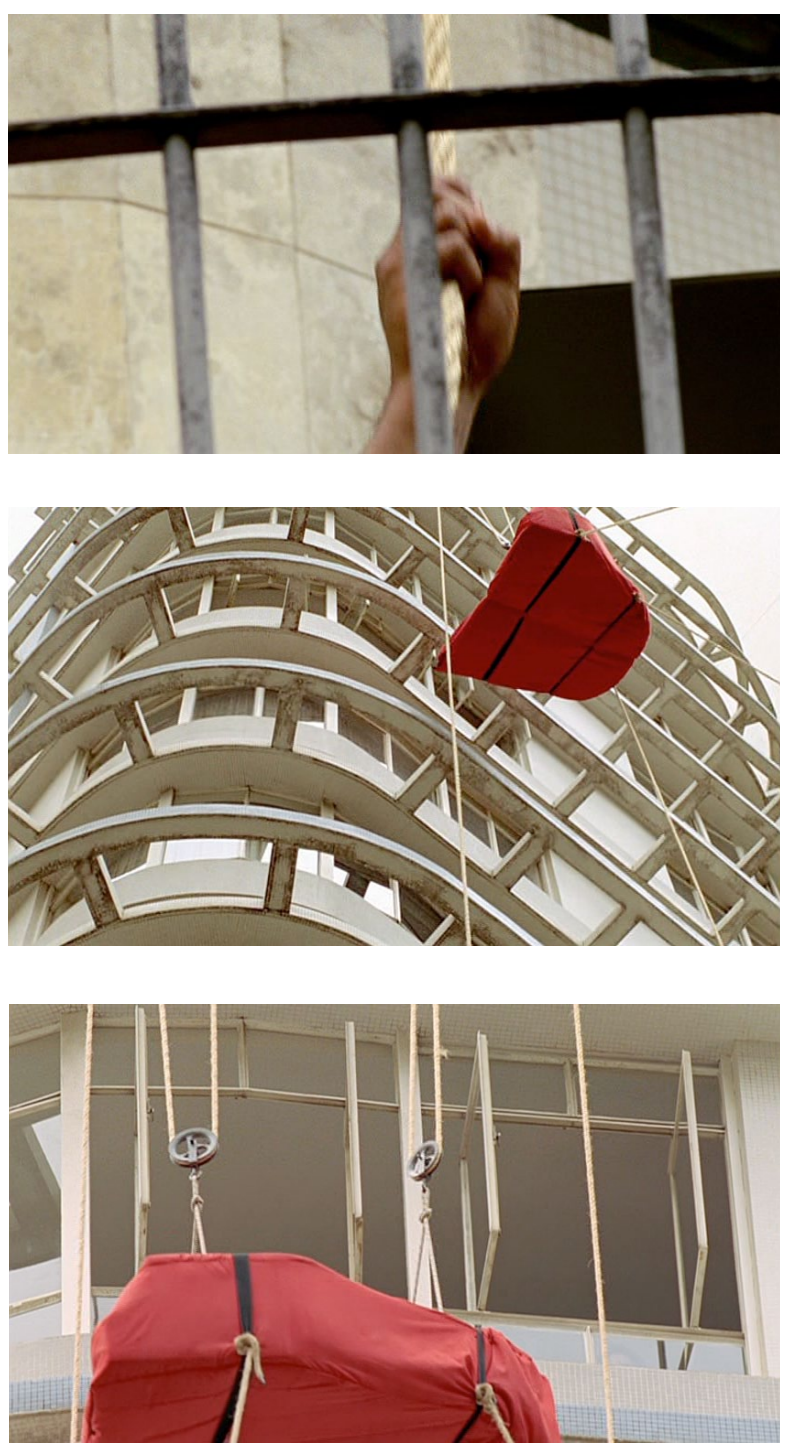

Figuras:

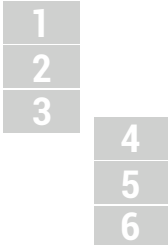

Primeiros planos do filme enfatizam o movimento vertical do piano. A descida do instrumento mimetiza a decadência dos personagens que se inicia.
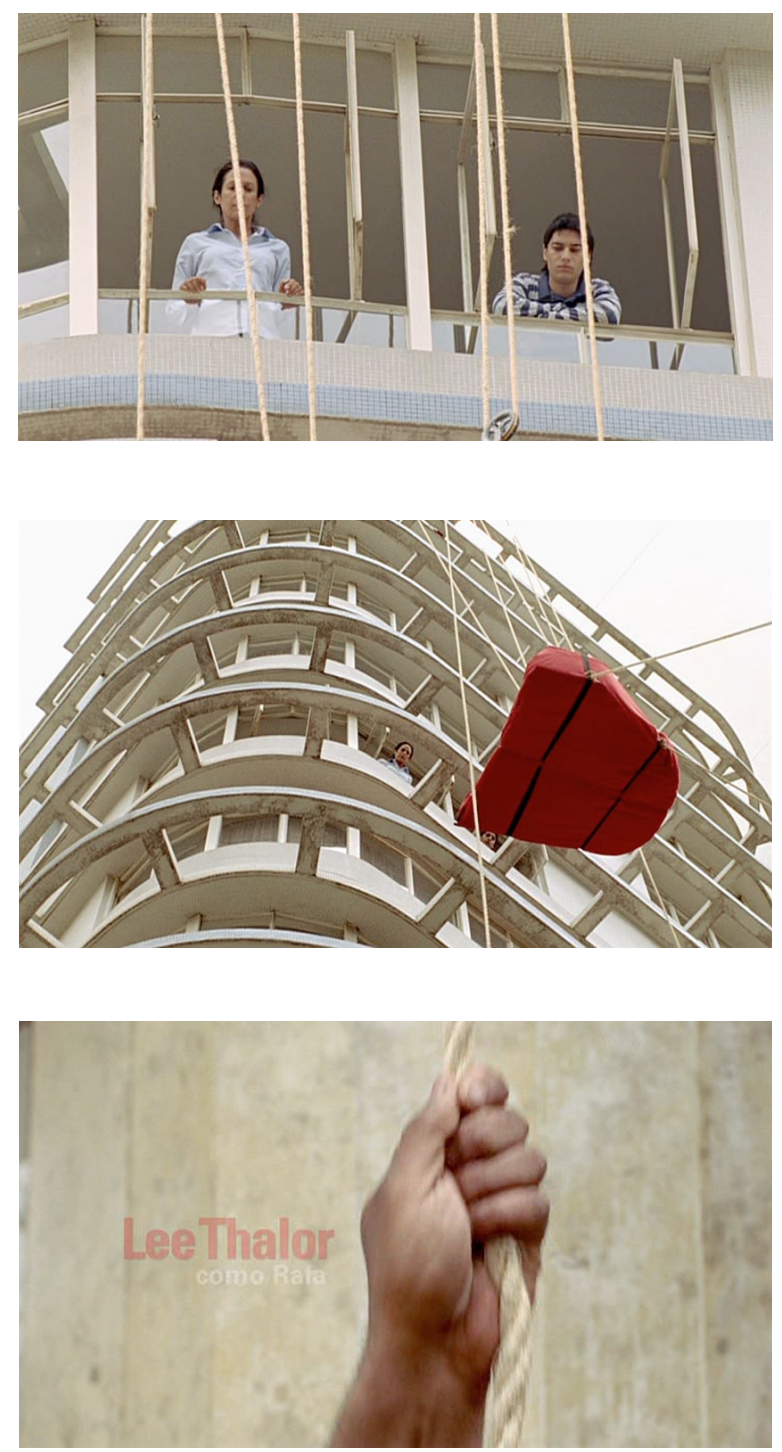
construída uma rima visual que antecede e anuncia o deslocamento na cidade.

Como veremos, essa verticalidade, que aqui é exacerbada, contrastará com o restante do filme: os personagens descem para não mais subir. A seguir passamos para a vista aérea do centro de São Paulo e atravessamos a paisagem dominada por prédios onde se destacam a Catedral da Sé e o prédio do Banespa. Por baixo percorremos o túnel do Anhangabaú e, novamente do alto, a Avenida Paulista que, enquadrada literalmente de cima para baixo, parece uma maquete. O deslocamento percorre o eixo horizontal da gigantesca cidade até chegar à periférica nova casa. Esse movimento que inaugura a trama mimetiza a mudança que é geográfica e também social.

No deslocamento o piano de cauda tem bastante destaque: ele nos introduz à família (o instrumento coberto pela vibrante capa vermelha aparece antes dos personagens) e sua entrega no novo lar encerra a sequência introdutória. A escolha de destacar esse objeto não é fortuita: além de ser instrumento de trabalho (Lúcia é professora de piano) ele simboliza o status social da família que, com a decadência, terá que se separar dele. Mas, mesmo quando Lúcia se separa do piano, o classicismo do instrumento não se separa do filme, pois é recorrente na banda sonora. Junto dessas primeiras imagens somos apresentados também à música tema do longa: Slavonic Dance No. 2 (do tcheco Antonín Dvorák), música clássica que, ao longo do filme, voltará como som extradiegético executado por uma orquestra, e também como trilha diegética tocada por Lúcia em seu piano e por uma dupla em um concerto que a personagem assiste. Como nessa sequência inicial, Slavonic Dance (ou a "Dança Eslava") imprimirá harmonia e certa melancolia nos demais trechos em que retorna mesmo quando na tela vemos uma ação bruta (como o assassinato do juiz que será comentado a seguir). Como discutirei ao fim, a música-tema se aproxima de Lúcia e, como ela, a canção contrasta com o ambiente onde a trama se passa.

Logo no início do filme, a tentativa de se restabelecer após a morte do marido é rapidamente abalada. No primeiro dia após a mudança, precisamente no Dia das Mães, por 
um "golpe do destino", Rafa mata uma jovem durante uma briga no racha que participava e é preso. Reforçando o tom do drama familiar e o ponto de vista do filme, que se concentra no da família de classe média, após ressaltar o desespero de Lúcia com a prisão do filho, somos introduzidos junto com Rafa no universo carcerário.

Com essa premissa, paralelamente, nos aproximaremos do PCC dentro e fora das cadeias onde Lúcia e o filho têm de enfrentar e se adaptar às mudanças. Transferido com a "liderança do partido"7 , Rafa dividirá a cela com Xis - entusiasmado membro da facção. Mesmo sem estar de acordo com a cartilha do PCC, Rafa se integra ao novo ambiente e se conforma com as regras como condição de permanecer bem e, principalmente, vivo na cadeia. Desnorteada e sem lecionar, pois perdera os alunos com a mudança para a periferia, Lúcia procura a ajuda de Ruiva. A personagem que, literalmente, tem cabelos vermelhos, assessora a facção e, com sua exímia experiência, passa a aconselhar Lúcia sobre trâmites e trambiques no sistema penal e judiciário. Ruiva também oferece a Lúcia pequenos trabalhos ou "favores remunerados" que garantem o dinheiro necessário para manter privilégios do filho na cadeia e que inserem cada vez mais Lúcia no universo do crime.

A história se desenvolve seguindo o modelo da narrativa clássica: a trama é conduzida pela meta perseguida por Lúcia com a forte relação causa-efeito ${ }^{8}$ ou, conforme Deleuze, através da ação-reação (ou situação-ação-situação) que representa a grande forma da imagem-ação que caracteriza o cinema clássico. A situação (prisão de Rafa) toma por completo a personagem, que reage - Lúcia se aproxima de Ruiva e do PCC -, numa (re)

\footnotetext{
${ }^{7}$ A existência de liderança no PCC é intensamente questionada pelos antropólogos - ver Biondi (2010), Marques (2010) e Biondi; Feltran; Marques (2009).

${ }^{8}$ A relação causa-efeito é para Bordwell a base da narrativa clássica, modelo que, para Thompson, é movido pela meta perseguida pelo protagonista apud DANTAS, Luiz Augusto. Roteiro cinematográfico: narrativa clássica, estudo e aplicação. 2010. Tese (Doutorado em Ciências da Comunicação) - CRT-ECAUSP. Universidade de São Paulo, São Paulo, 2010, p. 72.
} 

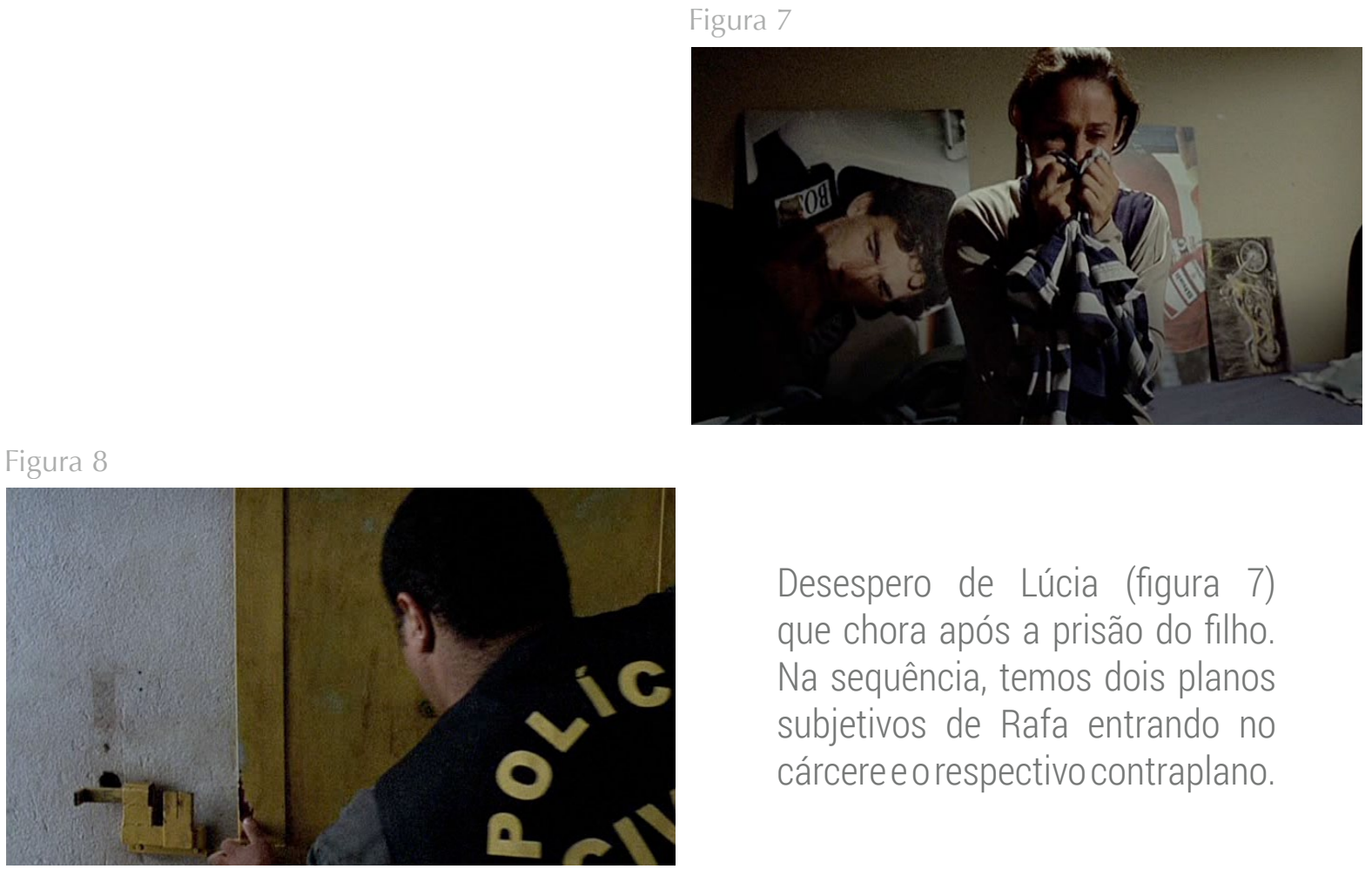

\section{Desespero de Lúcia (figura 7) que chora após a prisão do filho. Na sequência, temos dois planos subjetivos de Rafa entrando no cárceree o respectivo contraplano.}
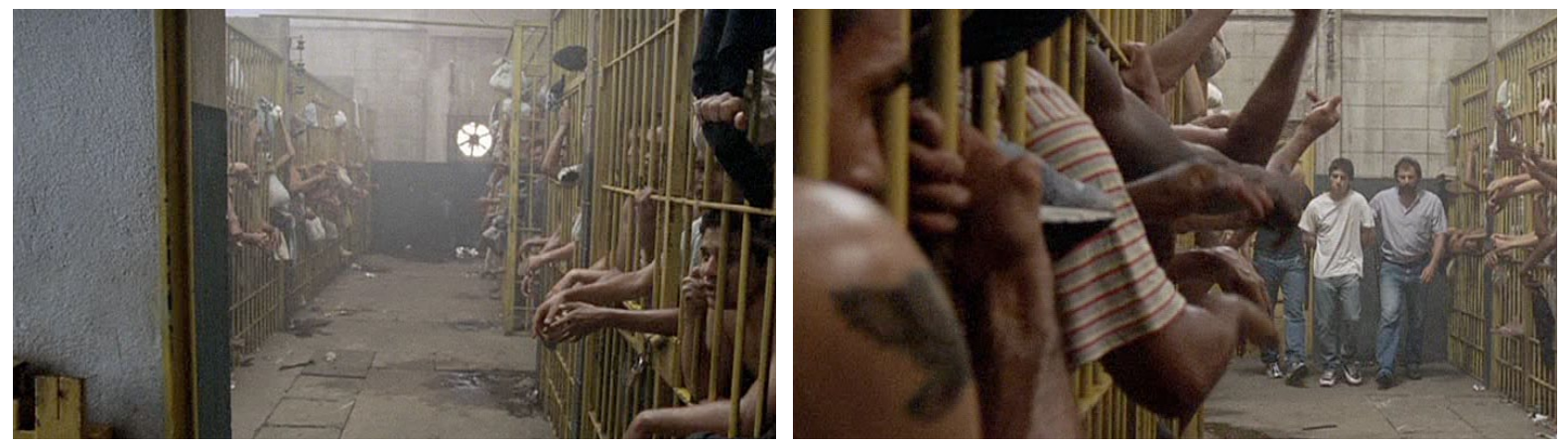

Figura 9

Figura 10

ação que cria uma nova situação ${ }^{9}$. A cada ação uma reação sempre é delimitada de acordo com a nobre meta da personagem de proteger o filho. Nesse esquema, a prisão de Rafa motivará a inserção de Lúcia no mundo do crime, isto é, no universo do PCC.

Com os "favores remunerados", entre encomendas e recados aos presos, veremos a ingênua professora de piano gradualmente adquirir agilidade e expertise no meio criminal. Além das mudanças no corte de cabelo e figurino, esses "favores" vão modificando Lúcia, que vai perdendo sua inocência. Em seu segundo "favor", Lúcia vai ao presídio de Avaré consultar se Professor é favorável ou contrário à ideia de executar o juiz que não autorizou

\footnotetext{
${ }^{9}$ DELEUZE, Gilles. Cinema 1: a imagem-movimento. São Paulo: Brasiliense, 1985, p. 178-179.
} 
sua transferência. Marcando a mudança da personagem, a cena em que Lúcia dirige na estrada rumo ao presídio remete ao motivo visual e sonoro da cena de Psicose (Hitchcock, 1960), quando Marion Crane foge da cidade com os 40 mil dólares da imobiliária onde trabalha. Se como Marion, Lúcia se move rumo ao crime, diferentemente da personagem estrangeira, a paulistana encontrará um par romântico, se integrará ao PCC e, ao fim, sairá viva.

Ao saber do assassinato do juiz que encontrara durante a consulta ao Professor, Lúcia volta ao presídio, dando início ao ardente relacionamento com o galante e culto detento. Inicia-se também uma integração mais plena dela com o partido: Lúcia não mais titubeia, passando a fazer "favores" cada vez mais complexos em São Paulo e também em Foz do Iguaçu. Assim, na cadeia e do lado de fora, mãe e filho restabelecem a harmonia ao lado do PCC para que - de acordo com a estrutura clássica - tenham suas trajetórias novamente atiçadas: primeiro com o assassinato de Professor e então com a onda de ataques, quando nos presídios e nas ruas "o salve [para atacar] é geral"10.

Na narrativa, a importância da cobertura midiática, que será exacerbada com os ataques, surge com o assassinato do juiz. A sequência desse assassinato é construída de modo perturbadoramente bela. Partimos da loja onde Lúcia vendera seu piano. Com alegria de rever o instrumento, ela executa a música tema do filme. Em continuidade sonora a trilha segue na cena seguinte em que, na saída de casa, o juiz é morto. Além do violino que, na passagem entre os espaços, acompanha a melodia do piano, o som do cantar de pneus torna a trilha ainda mais dramática. A seguir, Lúcia volta a ser conectada à outra cena através do televisor que, mantendo a continuidade agora através da imagem, exibe o juiz executado.

Além de surgir como som e como imagem através do televisor, a mídia aparece

\footnotetext{
${ }^{10}$ No "glossário de termos nativos" de Junto e Misturado, a expressão "Salve Geral" é definida como "comunicado a ser amplamente divulgado". BIONDI, Karina. Junto e Misturado: uma etnografia do PCC. São Paulo: Editora Terceiro Nome, 2010, p. 244.
} 

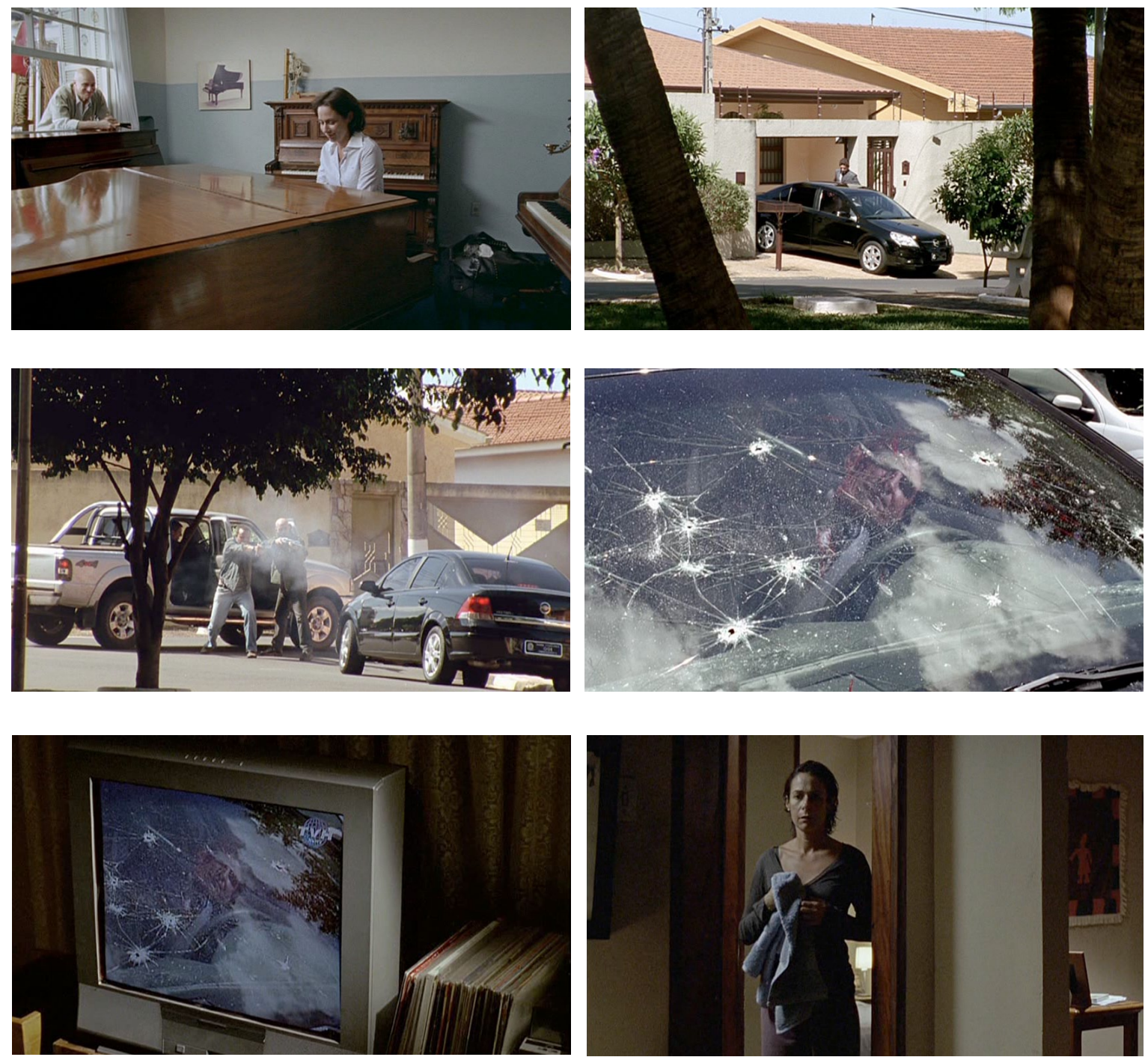

Figuras:

\begin{tabular}{|l|l|}
\hline 11 & 12 \\
\hline 13 & 14 \\
\hline 15 & 16 \\
\hline
\end{tabular}

Da loja de piano (figura 11) passamos à casa do juiz (12) e ao assassinato (13 e 14) e, em continuidade visual, à casa de Lúcia (15 e 16).

ao longo de todo o filme como estratégia manipulada pelos presos e pelo poder público. Antes dos ataques a mídia será manipulada pelos membros da segurança pública e do sistema penitenciário que reconhecem o poder dos meios de comunicação para melhorar sua imagem e ganhar votos; "é sangue e mídia", pois "bandido morto é igual a voto" diz o Delegado Raul a D’Ávila - responsável pelo presídio onde Rafa e a maior parte dos "líderes" do PCC estão. A empreitada é posta em prática com a emboscada armada contra Tirso - preso que garante sua condicional entregando criminosos ao Delegado. 
Descumprindo o acordo feito com Tirso, ao invés de prender os criminosos e exibir a ação na mídia, a emboscada vira um banho de sangue. Pouco antes de ser assassinado por haver traído o partido, Tirso assiste Raul vitoriosamente falar à TV que a inteligência da polícia deu um duro golpe na facção ao interceptar assaltantes que morreram no confronto. Do mesmo modo, após encontrarem explosivos que, estrategicamente, foram denunciados por Ruiva, a primeira reação do Secretário da Segurança Pública é convocar a imprensa.

Com os ataques, os meios de comunicação também se tornam ferramentas para os membros do PCC: para manter o pânico e abalar ainda mais a imagem do Estado, Ruiva pede para um "irmão" ligar para uma repórter e dizer que há uma bomba no aeroporto. Após o acordo com o Secretário de Segurança Pública, um dos detentos caçoa ao dizer que, para espalhar o "cessar fogo" com a velocidade que se quer, precisaria acessar a cadeia nacional de rádio e televisão. Se, por um lado, ambos os grupos reconhecem o poder da mídia para promover seus interesses (seja o de melhorar sua imagem e obter votos, seja o de acuar o governo), por outro, os presos não têm o mesmo acesso e espaço na mídia que os membros da segurança pública e, diferentemente do que se passou na vida real (com o sequestro do repórter comentado na introdução), em Salve Geral os membros do PCC não falam diretamente às emissoras.

Com o início da série de ataques - motivados pela transferência da "liderança" à "tranca dura" (presídio de segurança máxima), a mídia se torna ainda mais presente na narrativa e, além de ser uma estratégia, surge com constância como veículo que exibe rebeliões e ataques em notícias que incidem sobre, e que também são apropriadas pelos personagens. As reportagens do rádio e da TV irão também costurar ações que se

\footnotetext{
${ }^{11}$ De modo curioso, no longa, os que deveriam ser "irmãos" são chamados de "primos". No léxico do PCC, diferente dos "irmãos" (presos filiados e batizados pelo PCC) o "primo" é o preso que, apesar de não pertencer ao PCC, convive, respeita e compartilha as normas do partido. MARQUES, Adalton. 'Liderança', 'proceder' e 'igualdade': uma etnografia das relações políticas no Primeiro Comando da Capital. Etnográfica, Lisboa, v. 14, 2010.
} 
desenvolvem em diferentes locais, como o assassinato do juiz que é conectado a Lúcia para os olhos do espectador - pela montagem que salta da loja de pianos para a rua e então para sua casa -, mas também para os olhos da personagem que assiste a notícia na TV.

Além da linguagem que será discutida a seguir, as reportagens do rádio e da TV têm aqui um papel que, em alguns momentos, remete ao do narrador e em outros aparece como elemento que move a ação, que informa espectadores e também os personagens que são afetados, motivados e impulsionados pelas notícias. É ao assistir à notícia da TV que Lúcia se dá conta de sua participação na execução do juiz. A seguir, é a reportagem da TV que a informa sobre os ataques que se iniciam após a soltura de Rafa no indulto do Dia das Mães. Além da TV, o áudio do rádio surge nos veículos narrando o estado da cidade e o desenvolvimento das rebeliões, contribuindo assim para construir o clima de caos que, após a onda de ataques, se instaura na cidade.

Como narrador na figura "voz de Deus", o áudio do aparelho de rádio ligado no carro de Lúcia surge como uma voz over colocada sobre as imagens do filme. Como imagens de cobertura, vemos engarrafamentos, ruas desertas, lojas baixando as portas, pontos de ônibus lotados e pessoas correndo (situações que se integram às ações da personagem) e que reforçam o jargão do "pânico" Assistir a sequência e do "caos que se espalhou pela cidade". Na resolução que vimeo.com/102768383 antecede o desfecho do filme esse cenário - em certa medida produzido pelas próprias notícias - opera como antagonista: como trocar dólares com a cidade parada pelos boatos de bombas e toque de recolher?

Mas os personagens não são apenas passivos receptores das notícias. Além de atuarem naquilo que é noticiado (ataques, assassinato, emboscada), os personagens interagem com as reportagens. Além das reações que as notícias provocam, como a discussão de Lúcia com a irmã e o descontentamento de Ruiva com o fim dos ataques, de modo instigante, as imagens da TV são utilizadas em calorosa discussão entre os representantes da Segurança 
Pública do Estado. Nessa cena, a fala do Delegado Raul opera como uma narração sobre as imagens transmitidas pelo televisor ligado na sala de reunião. Exaltado com D'Ávila que não quer negociar com os presos, Raul aponta para o televisor. As imagens de ônibus em chamas, viaturas, base policial, vidro quebrado e rebelião que o aparelho exibe continuam junto à fala do personagem: "297 ataques de bandidos, 23 policiais mortos, 100 ônibus incendiados, 70 presídios rebelados e você é contra? A cidade parada, a população em pânico, o governo contra a parede e ele é contra? Com certeza ele tem uma proposta melhor pra fazer do que negociar".

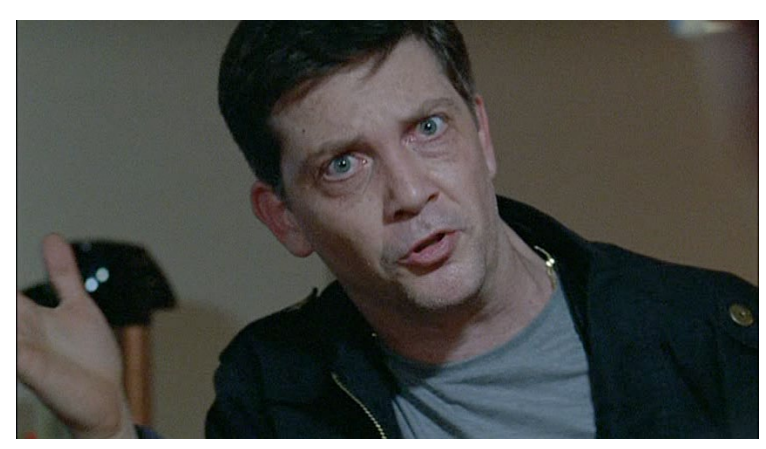

Figura 17

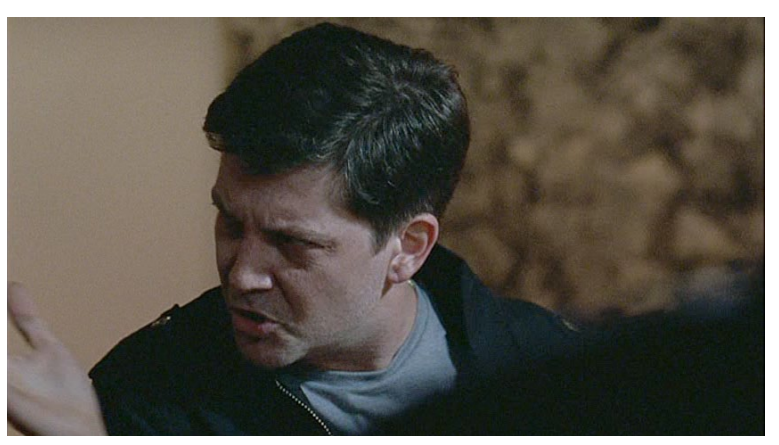

Figura 18
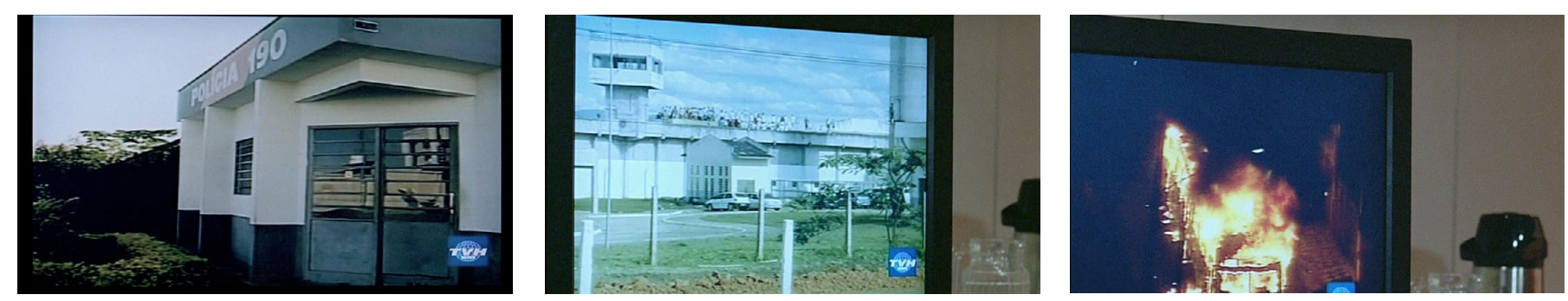

Figuras 19, 20 e 21

Figuras 17 a 22: Delegado Raul começa sua fala exaltado, apontando à $T V$, que exibe as imagens 19, 20 e 21.

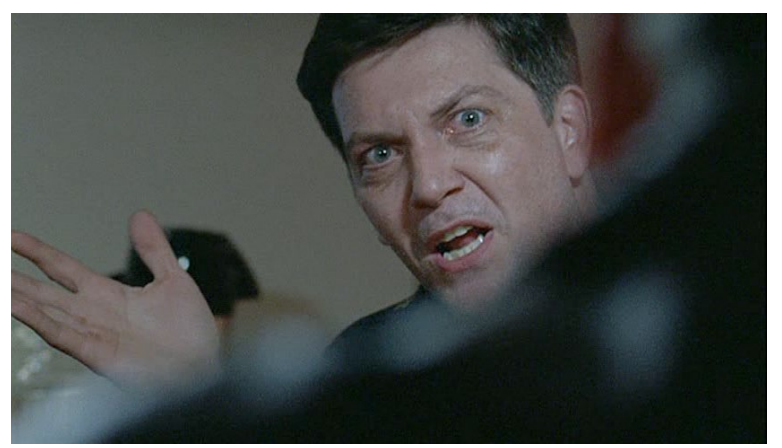

Figura 22 
A fala lançada sobre as imagens opera como a narração do rádio, mas invertendo a relação, pois agora é o personagem quem confere sentido às imagens da mídia. Contribuindo para o tom de urgência, aqui e nas demais reportagens, o filme se apropria do ritmo da TV. Essa união imagens-fala de Raul remete ao estilo do programa Brasil Urgente (ao qual os personagens de Inquilinos assistem e é parodiado em Tropa de Elite 2), tanto pela forma enérgica com que o personagem se pronuncia, exigindo que o Estado atue, quanto pelo conteúdo que nos apresenta o caos produzido pelo crime. Junto ao jornal trazido pelo Secretário e da presença desse televisor na sala de reunião, a cena reforça a importância da mídia nas considerações do Estado (a reunião se inicia com o Secretário lançando um jornal na mesa e dizendo "sinceramente não sei mais o que fazer, isso nunca aconteceu em São Paulo"). A cena reforça também a importância da mídia como parte da narrativa em uma intensa relação entre reportagens e trama. A integração é reiterada com as imagens que fecham a cena - figuras 23 a 27 abaixo. Nelas, como que em um degradê, passamos da textura rústica e ruidosa para a fotografia mais limpa que predomina no filme.

Com a impossibilidade de percorrer as coberturas dos ataques realizadas pelos telejornais ${ }^{12}$ é impossível identificar todas as imagens de arquivo. Todavia não é essencial reconhecer o que é documental e o que é encenação: o que se destaca no filme é o intenso desejo de manter o código das reportagens, mesmo quando claramente são emuladas. A busca por manter o código do telejornal se expressa nas reportagens que explicitamente fazem parte da ficção, como naquelas em que os personagens aparecem (o juiz assassinado, as entrevistas de D'Ávila e Raul), na abertura do telejornal que Lúcia assiste e também no final da sequência de imagens abaixo. Nessa sequência o plano do ônibus em chamas (figura 26) nitidamente foi produzido para o filme, pois o modelo do veículo é antigo e não corresponde aos coletivos que circulavam na cidade em 2006. Nessa reprodução, o

\footnotetext{
12 Dos contatos que fiz para acessar o material de telejornais tradicionais (que, como comentarei, são mimetizados e incorporados pelo longa) a única reposta obtida foi a negativa da Rede Globo.
} 

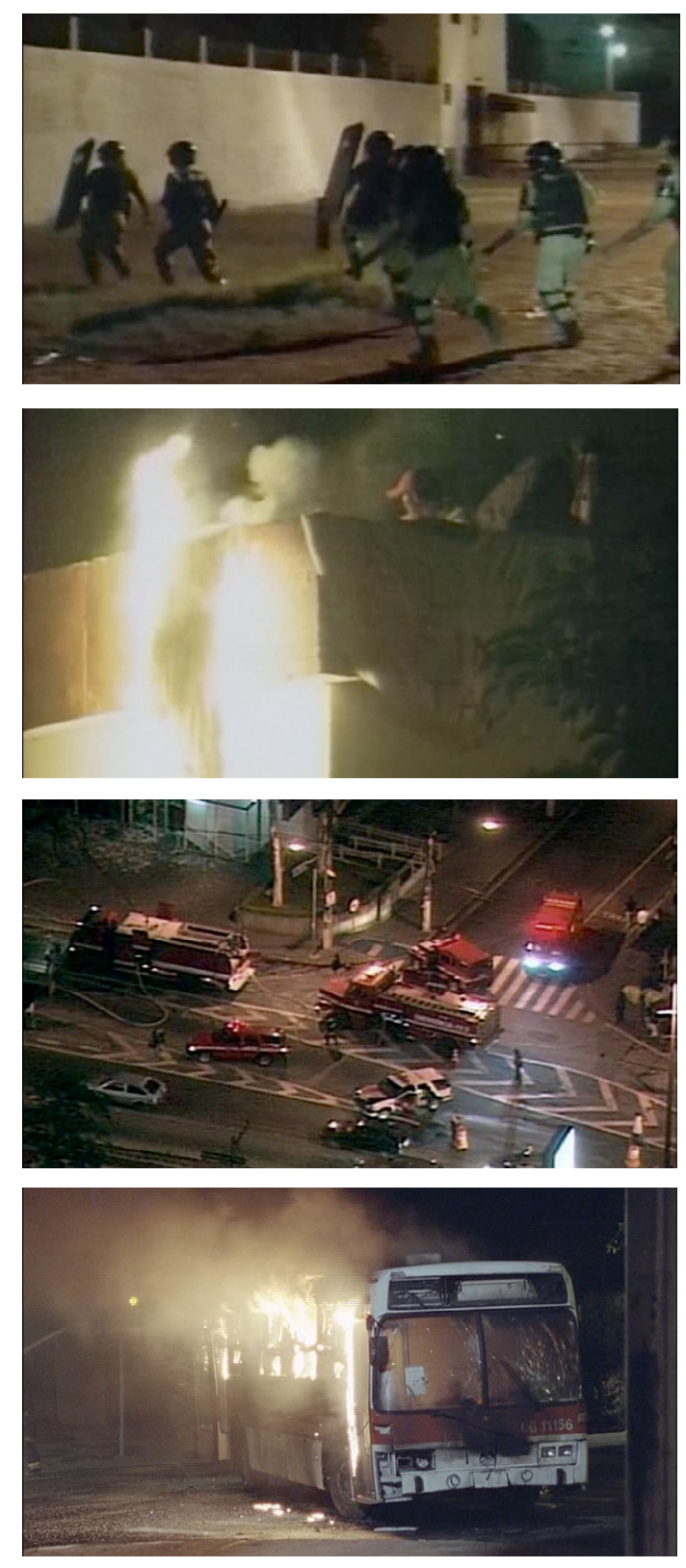

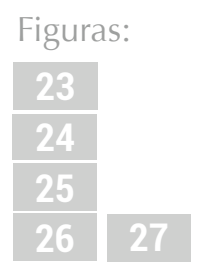

\section{Evolução da textura ruidosa das imagens - que parecem ser de arquivo (23 e 24) aos planos que foram feitos para o longa (25 a 27$)$.}

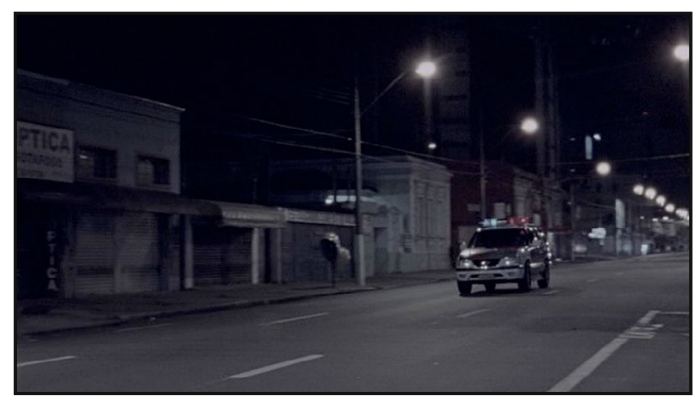

enquadramento remete às imagens vistas em reportagens, como na foto abaixo que foi veiculada em maio de 2006. Em outros momentos (como na figura 27), a limpeza da imagem também sugere sua emulação.

Assim, nas reportagens e em alguns planos em que vemos a rebelião no presídio central da trama, fica clara uma intensa inspiração iconográfica do filme que incorpora signos e enquadramentos que remetem às imagens que povoaram a mídia (mais especificamente os veículos tradicionais) no período. 


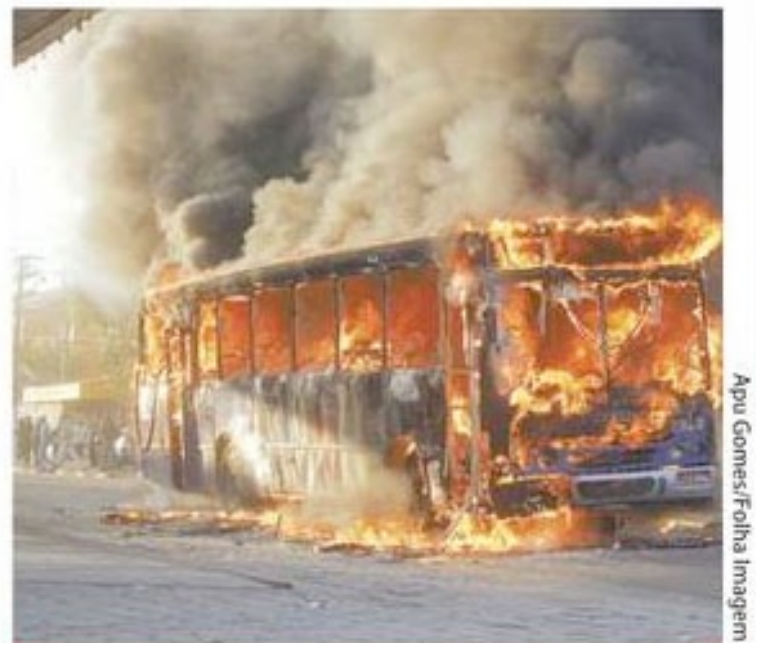

Coletivo em chamas (foto publicada pelo jornal Folha de São Paulo em 16/05/2006).

Figura 28

Mais do que aumentar o efeito de realidade da ficção através da incorporação das reportagens e de seus signos, ao se apropriar das imagens e dos códigos das notícias, Salve Geral aponta para o fato de que “(..) as duas formas de representação [meios de comunicação e ficção] existem como parte de um continuum (...)"13, de uma relação contínua que é constituinte do cotidiano onde ela se estabelece. Em Salve Geral a continuidade se mantém mesmo com o contraste das linguagens que caracterizam cada forma de representação (isto é, linguagem clássica da ficção e certa convenção midiática), contraste esse que será discutido a seguir.

Além da aproximação com as imagens veiculadas no período, o filme aponta também para uma forte conexão com as informações transmitidas pela cobertura midiática entre ações do PCC, estado da cidade, evolução do conflito, negociações, crise na segurança pública e reação "paraestatal" (como na sequência em que o áudio do rádio opera como narrador). Mesmo quando não há presença literal da mídia, através dos sons e imagens das reportagens, Salve Geral retoma discursos que povoaram os meios de comunicação

\footnotetext{
${ }^{13}$ STAM, Robert. The Carandiru massacre: across the mediatic spectrum. In: ANDERMANN, Jeans; BRAVO, Álvaro. New Argentine and Brazilian Cinema - reality effects. Nova lorque: Palgrave Macmillan, 2013, p. 143 (tradução minha).
} 
Figura 29

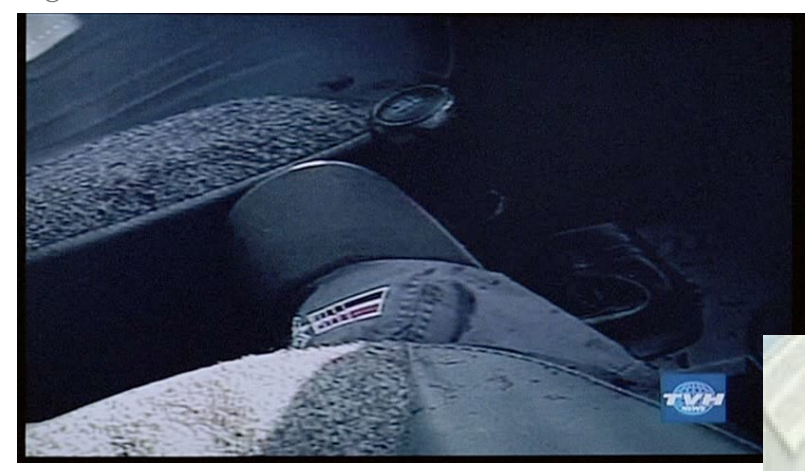

Figura 29 (à esquerda) imagem de reportagem vista no filme, e abaixo foto publicada no site da Folha de São Paulo, em 13/05/2006.

Vidro estilhaçado em imagem exibida como reportagem no filme (figura 31), e à direita vidro estilhaçado publicado em reportagem da Folha de São Paulo, em 15/05/2006.

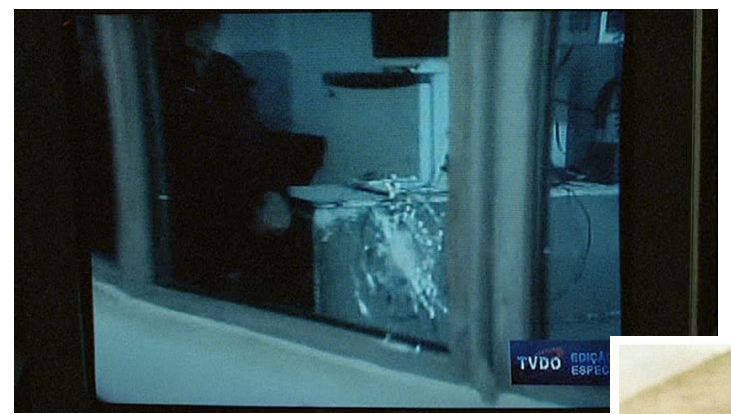

Figura 31

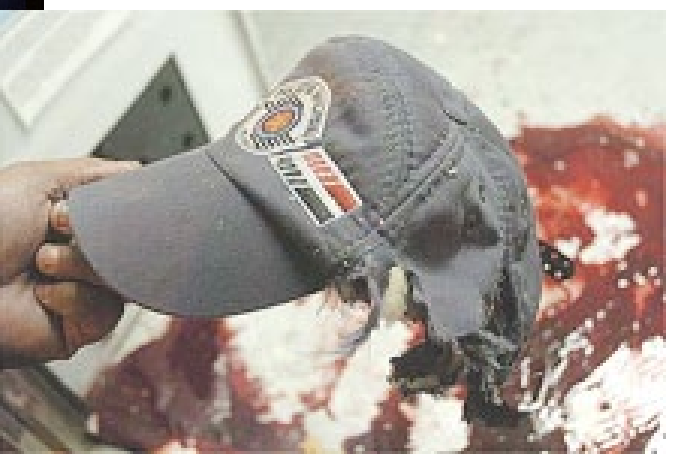

Figura 30

Figura 32

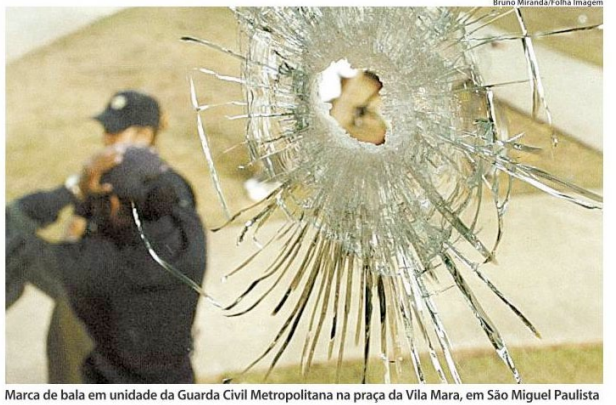

Figura 34
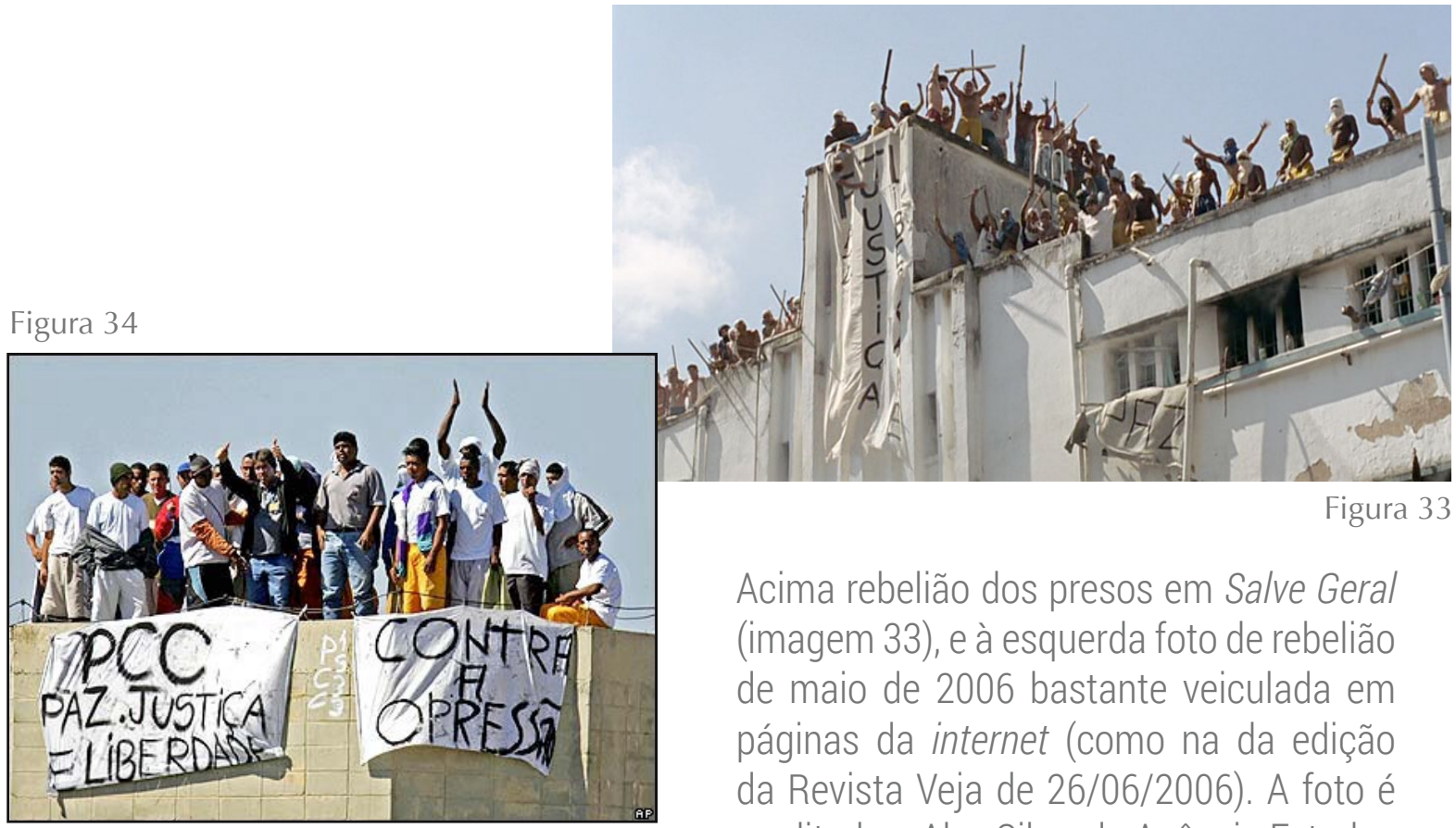

Figura 33

Acima rebelião dos presos em Salve Geral (imagem 33), e à esquerda foto de rebelião de maio de 2006 bastante veiculada em páginas da internet (como na da edição da Revista Veja de 26/06/2006). A foto é creditada a Alex Silva, da Agência Estado. 
na época e que, à exaustão, ressoaram o caos formado pelo maior engarrafamento da história da cidade, pontos de ônibus lotados e toques de recolher. Desse modo, além da inspiração iconográfica, vemos também certa relação mimética entre filme e aquilo que a mídia narrou sobre a evolução e desfecho dos ataques.

Os ataques aparecem na narrativa através da cobertura da mídia e também pela ação dos personagens. Os dois modos contrastam pela textura da imagem e também pela posição na qual somos colocados em contato com os ataques. Através das reportagens, os ataques são mostrados em uma postura distanciada - que remete ao posicionamento do telejornalismo convencional. Na fotografia, o ruído, a granulação e coloração distinguem esses trechos daquilo que predomina no filme. No segundo modo, quando vemos os personagens praticando os ataques, impera uma linguagem do filme de ação.

Mantendo o continuum, as duas linguagens se alternam e se conectam na sequência em que os ataques eclodem. Impulsionando o clímax, na metade final do filme, a sequência começa com a transferência de detentos após a polícia descobrir os explosivos que seriam detonados na Bolsa de Valores (a ordem teria partido do presídio). Com as imagens dos prisioneiros caminhando para os "bondes", veículos que os transportarão, se inicia a trilha "Presos transferidos", composição original do filme $e^{14}$ que já aparecera durante a rebelião no Distrito Policial no início da trama. A trilha tem diferentes momentos, mais e menos intensos. Com variações no volume, ela continuará por quase oito minutos entre as diversas ações paralelas de presos, Ruiva, D’Ávila, Lúcia (que se prepara para receber e buscar o filho) e Rafa que, liberado com o indulto do Dia das Mães, é convocado para ajudar nos ataques. Num crescente que antecipa que algo está para acontecer, a música tem seu momento mais forte em frente à delegacia, cena que é a mais intensa nos moldes do filme de ação.

\footnotetext{
${ }^{14}$ Trilha original "Presos transferidos", composta por Miguel Briamonte para o filme. Disponível em: <https://soundcloud.com/miguelbriamonte>. Acesso em: 10 jun. 2014.
} 
Diferente da decupagem clássica e branda que predomina no primeiro trecho do filme, marcada por planos estáveis articulados com fluidez e certa invisibilidade pela montagem, nas cenas de ação que se tornam mais frequentes com os ataques, a estabilidade é colocada de lado em uma composição alinhada aos filmes de ação. Esse estilo é marcado pela abundância de movimentos (do quadro e no quadro) que, pela velocidade e pela forma abrupta como se dão os cortes, produzem choques, ou sobressaltos entre as imagens articuladas e, mantendo o tom do gênero, buscam o êxtase. A perseguição em Máquina Mortifera (Richard Donner, 1987) exemplifica o esquema que “(...) busca o máximo senso de movimento, com ações fluindo através de cada imagem; comumente, nenhum movimento será completo em um plano. A montagem é rápida, criando em média planos de dois segundos e meio"15.

Como na cena do racha, em que Rafa comete o assassinato que o leva à cadeia, e da emboscada a Tirso, os ataques também surgem na trama através da composição frenética. De volta ao primeiro ataque do filme, sua cena dura menos de um minuto e é composta de trinta e seis planos. Os curtos fragmentos - com média inferior à descrição de Bordwell (o menor dura apenas nove quadros, aproximadamente 1/3 de segundo), mostram plano e contraplano do ataque e são repletos de tiros, fumaças e explosões. Em alguns curtos momentos a câmera na mão se move nervosa à procura da ação, produzindo imagens que contêm pouca nitidez e inteligibilidade, mas que, no conjunto dos fragmentos, expressam uma cena extremamente fervilhante.

A linguagem clássica que predomina no longa nos lança no universo fílmico como que através de uma janela ${ }^{16} \mathrm{e}$, nos momentos de ação intensa, nos coloca por alguns instantes como que no interior do conflito, e então experimentamos o balançar e o choque das

\footnotetext{
${ }^{15}$ BORDWELL, David. Aesthetics in Action - Kung-fu, Gunplay, and Cinematic Expression. In: Poetics of Cinema. Nova lorque: Routledge, 2008, p. 397 (tradução minha).

${ }^{16}$ XAVIER, Ismail. O discurso cinematográfico: a opacidade e a transparência. São Paulo: Paz e Terra, 2005.
} 
explosões, a visão pouco nítida, fragmentada e instável que corresponderia à experiência da ação em que a não fluidez seria potente para produzir o êxtase. Essa montagem volta a aparecer em outros ataques e fugas que, na banda sonora, se aproximam também do estilo de ação pelo constante cantar de pneus, estrondos e também pela proximidade da trilha (a mencionada "Presos transferidos") que, de modo genérico, remete a outros filmes de ação.

Após a série de quatro ataques (tiros contra delegacia, coquetéis molotovs lançados a veículos e caçamba, disparos contra policiais militares e incêndio de coletivo), passamos à reportagem da TV cujo som da chamada se conecta com os violinos que encerram a trilha de "Presos transferidos" a qual se manteve durante toda a sequência. Em frente ao televisor Lúcia assiste a reportagem sobre os ataques e fica ainda mais preocupada com Rafa, que ainda não dera sinais após o indulto. Com o início dos ataques a mídia aparecerá com intensidade no desenrolar da trama e, nessa sequência, a passagem da intensa ação para a reportagem reforça as diferenças entre as duas linguagens - das notícias e da ficção nos moldes do filme de ação.

A construção dos ataques através da TV difere da intensidade das cenas que nos lançam no interior da ação e também da fluidez da decupagem clássica. Além da textura mais rústica e da coloração que varia do azul ao amarelado, as imagens das notícias contrastam com o restante do filme pela posição distanciada que mantêm em relação ao que noticia. Essa posição se assemelha ao estilo da cobertura midiática que nos apresenta conflitos e ameaças de modo distanciado - distância física (pelo enquadramento) e temporal (pois exibe marcas do que se passou). Apesar de em sua dinâmica o telejornal ser mais imediato que o cinema, fora flagrantes e casos excepcionais (como o desmoronamento da segunda torre do World Trade Center e das cenas captadas por cinegrafistas amadores) a equipe da TV chega depois da ação, isto é, as câmeras não estão a postos quando a ação eclode. Além disso, a reportagem que vai ao ar é editada e narrada de modo a explicar o que se passou. De modo inverso, a posteriori o cinema pode reconstituir a ação e, como aqui, nos lançar 
em seu interior.

A linguagem midiática (re)produzida no filme seque o padrão do jornalismo e telejornalismo convencionais em que o conflito nos é apresentado com certo recuo que não chega a estragar o jantar: menos sensorial e direta, a violência é principalmente narrada e contada ${ }^{17}$. Apesar dos altos índices de violência fatal "existe uma tradição brasileira, trágica, de silêncio visual sobre a violência" 18 que prevalece na grande imprensa que, diferente do que podemos encontrar em veículos populares, não exibe corpos mutilados, nem se afilia ao formato inaugurado pelo programa Aqui Agora (1990), com a característica câmera trêmula que, literalmente, corre atrás da ação.

Como nessa tradição jornalística que apresenta os conflitos em um tratamento mais "brando", nas reportagens inseridas na diegese do filme, os ataques aparecem como um testemunho tardio do confronto ${ }^{19}$ através dos vestígios da ação que ocorrera, como fragmentos de vidro quebrado, boné da PM, vidro e parede furados por bala e bombeiros apagando fogo. Assim, as reportagens contrastam com o restante do filme pela textura ruidosa, coloração e também pelo posicionamento distanciado.

Nesse continuum entre drama, ação e reportagem, a mídia aparece como uma das vozes que enunciam no filme, remetendo à definição de Nichols para "voz do documentário". Nessa acepção a voz compreende a maneira como se organiza o material que o filme nos apresenta, “(...) algo semelhante àquele padrão inatingível, formado pela interação de todos os códigos de um filme (...)" ${ }^{20}$. Se no documentário a voz carrega fortes implicações éticas e é composta por narração (de sujeito dentro ou fora de quadro, ou com

\footnotetext{
${ }^{17}$ BENTES, Ivana. Estéticas da Violência no Cinema. Interseções: Revista de Estudos interdisciplinares, Rio de Janeiro, ano 5, 2003. Edição especial, p. 4.

${ }^{18}$ SALLES, João Moreira. Imagens em conflito. In: MOURÃO, Dora; LABAKI, Amir. O cinema do real. São Paulo: Cosac Naify, 2005, p. 85.

19 Ibid. Idem.

${ }^{20}$ NICHOLS, Bill. A voz do documentário. In: RAMOS, Fernão. Teoria Contemporânea do Cinema: Documentário e Narratividade Ficcional. São Paulo: Senac, 2005, p. 50.
} 
Figura 35

Figura 36
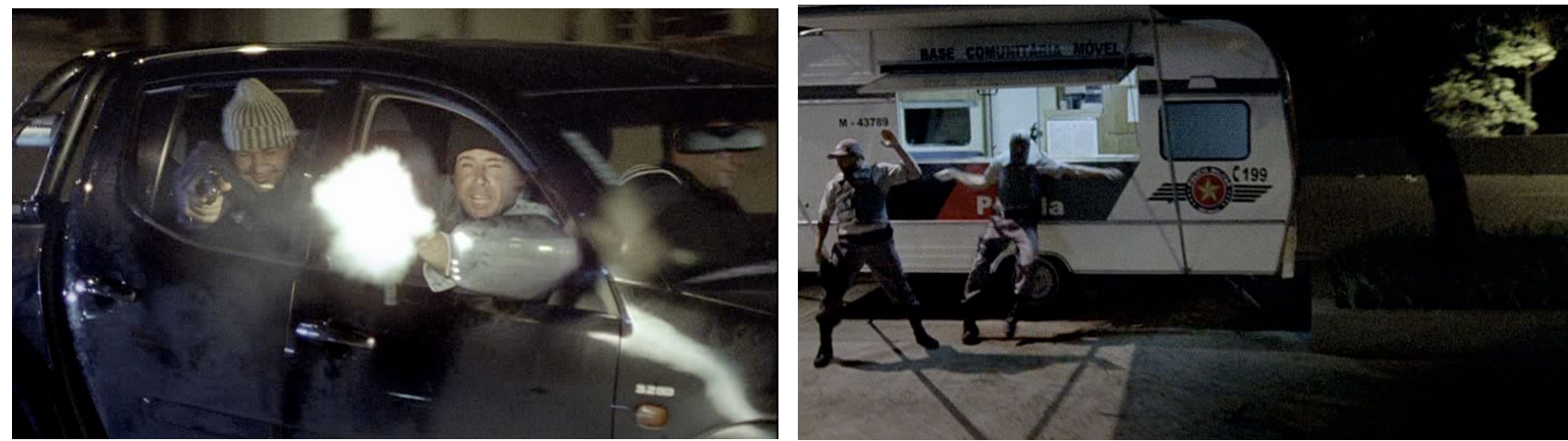

Figura 37

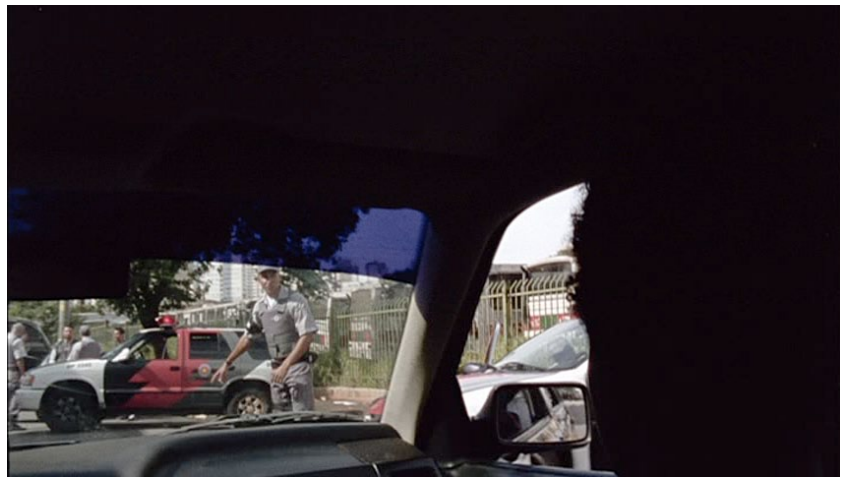

Figura 38

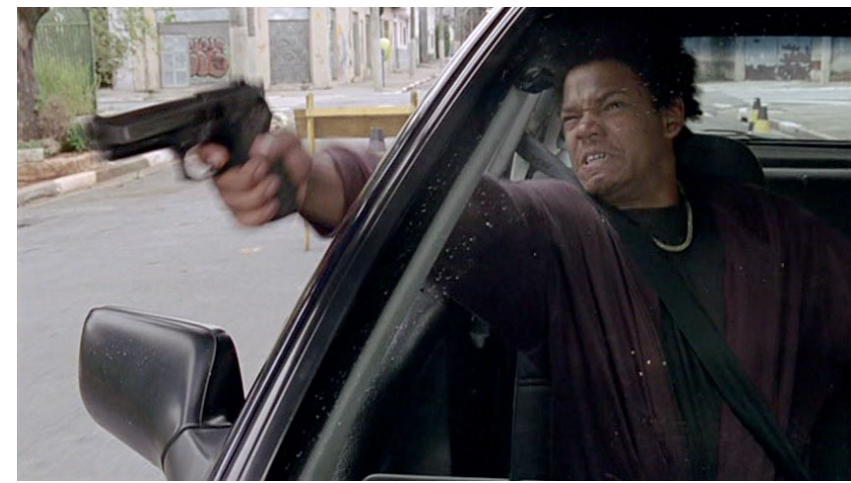

Figura 39

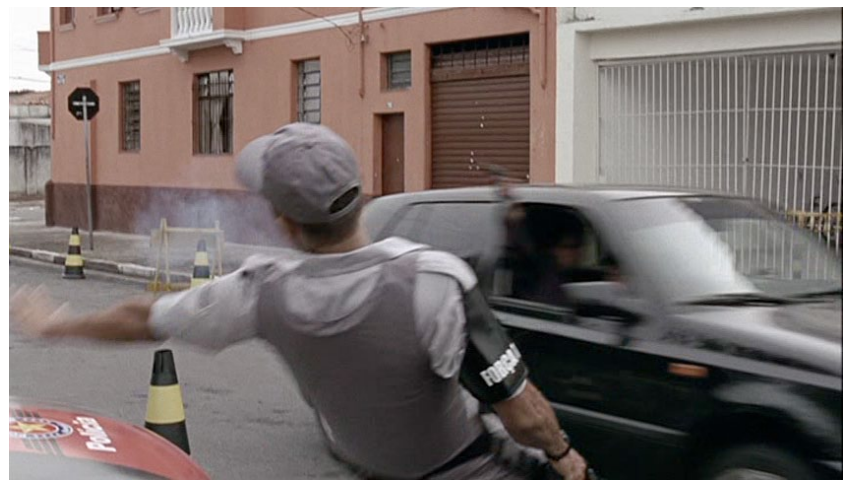

Figura 40

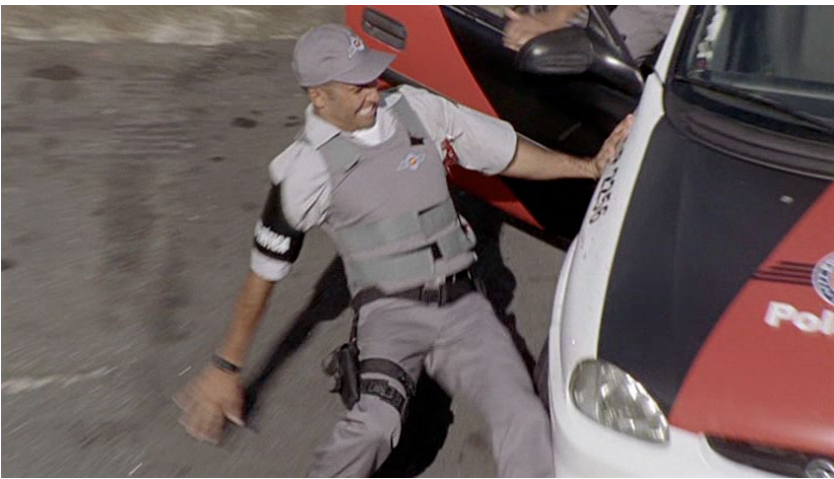

Imagens de ataques sendo cometidos nos moldes do "filme de ação". Imagens 35 e 36: passageiros metralham policiais na base comunitária. Imagens 37 a 40: Xis atira em policial dando início à fervilhante fuga conduzida por Rafa. 
Ao lado: imagens (41 e 42) da reportagem assistida por Lúcia que carregam a textura do telejornalismo e contrastam com as imagens do restante do filme pelo "ruído", pelo distanciamento físico e temporal em relação à ação e pela coloração (aqui) azulada.

Figura 41
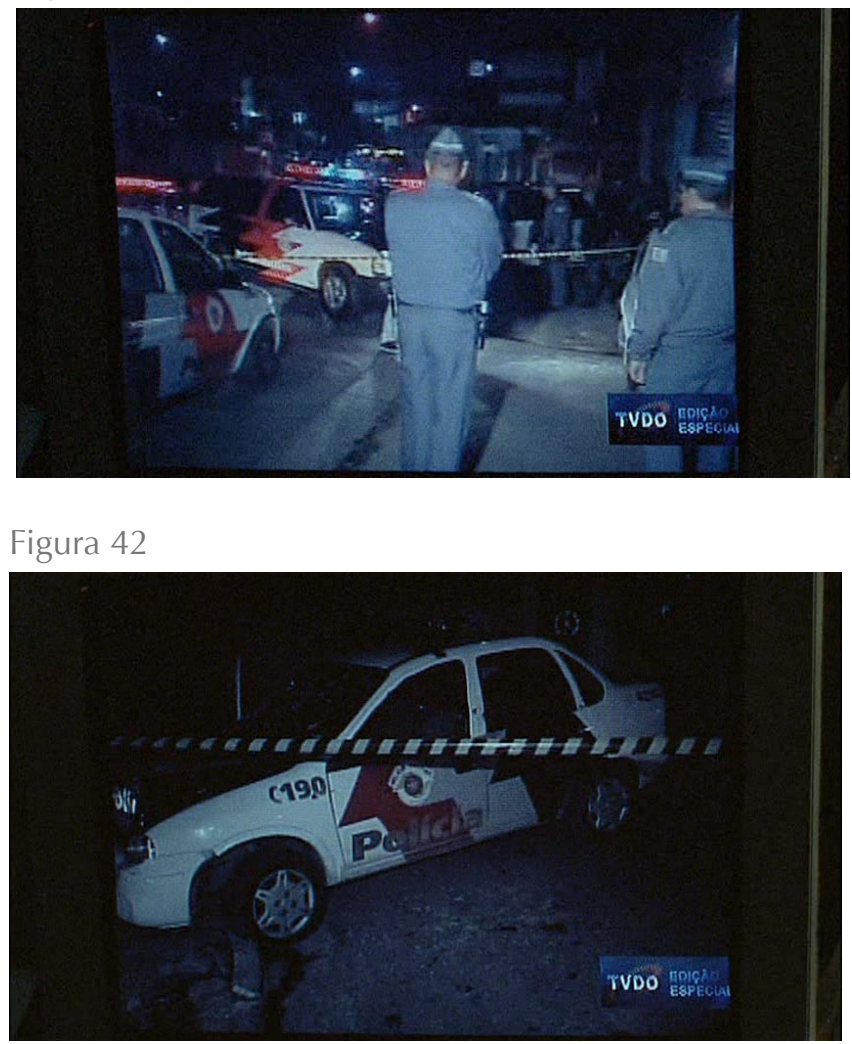

a "voz de deus"), trilha, fotos, entrevistas, que podem ser trabalhadas em uma postura reflexiva, interativa, e também através da performance, nessa ficção a voz é a totalidade dos elementos articulados: trilha, imagens e ações combinados na montagem. Integrando o corpo do longa, as reportagens compõem o material fílmico, sua voz, imprimindo seu código, seu modo de narrar que conferem a tônica do filme.

Vale destacar que nessa integração a mídia não surge como elemento que se impõe sobre os personagens (como veremos em Inversão), nem como entidade etérea que paira na diegese: em Salve Geral os personagens atuam naquilo que é noticiado e dão sentido ao que é exibido. Dentro do caos reportado (Lúcia no engarrafamento), participando ativamente da notícia (assassinato do juiz, boato e ataques) e aparecendo ainda "dentro" do televisor (depoimentos de Raul e D’Ávila), é construída uma integração plena entre mídia, personagens que transitam nas duas representações e, por fim, trama - fortemente calcada nas reportagens. 
Como discutido na introdução, os ataques de maio de 2006 se espalharam pela cidade (e pelo estado) e não focaram em um símbolo como o World Trade Center de Manhattan - atingido nos ataques do 11 de setembro que seguiram as convenções do espetáculo. Semelhante ao que fez a mídia na cobertura dos ataques de 2006, Sérgio Rezende pôde, com o cinema, reconstituir o fenômeno como espetáculo. À cata do sensacional (do "11 de setembro de São Paulo"), com recursos audiovisuais, os ataques articulados em meio ao drama familiar nos conduzem para dentro da ação onde o frenético surge através dos inúmeros tiros, explosões e fugas. Assim, as ações fragmentadas que eclodiram na cidade e vitimaram policiais, são recriadas de acordo com as regras do espetáculo, mais especificamente do filme de ação. Como na imagem-ação, a forte conexão entre ação-reação motivada pela nobre meta perseguida por Lúcia, personagem com quem somos convidados a nos identificar, tudo se torna razoável e palatável. No final ou ao longo de todo o filme “(...) a grande missão, santifica ou pelo menos absolve o herói por tudo que ele teve de fazer (...)"21

$\mathrm{Na}$ maior parte das vezes, a ação violenta dos ataques e de outras cenas, como a emboscada e o racha, é mostrada através da imagem literal da ação que exibe a violência explícita (rara no telejornalismo). Assim, o flagrante desse "11 de setembro" que Rezende parece buscar é reconstruído nas cenas de ação enquanto as reportagens do filme aparecem em consonância com aquelas que foram exibidas em 2006, isto é, não flagraram nada. Além da imagem literal, a violência aparece também através da linguagem, isto é, da montagem frenética e fragmentada. Na comparação entre os três títulos, apenas Salve Geral trabalha com essa violência explícita e sensorial que recria o evento como espetáculo cinematográfico: as ações espalhadas, difíceis (praticamente impossíveis) de serem capturadas pelas reportagens se tornam cenas de ação, repletas de luzes (das explosões, dos tiros) e com embates que contém uma alta carga de adrenalina.

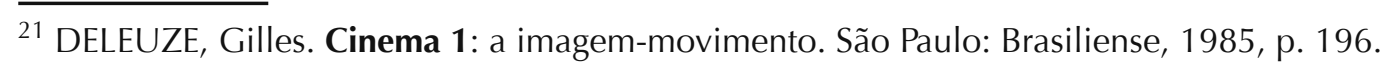


Em Salve Geral, o movimento marca e constrói a cidade fílmica. Da paixão de Rafa (apelidado de Piloto ${ }^{22}$ na cadeia) por automóveis, ao constante deslocamento de Lúcia entre visitas e favores, o trânsito figura também entre os elementos que movimentam a narrativa, além de ser fundamental na caracterização da cidade.

\section{Cidade-movimento: imensidão}

Na trama, que pode ser resumida como a aproximação de Lúcia e Rafa para dentro e então para fora da facção criminal, o movimento dos personagens também aparece de modo literal. Após a mudança inicial, que marca a decadência da dupla em literal movimento para baixo e então para as margens da cidade, o trânsito dos personagens é intenso, revelando (ou construindo) uma cidade imensa. Além de abrir o longa, o deslocamento da família também fecha o filme. Agravado pelo assassinato de Professor, após Rafa ser baleado durante os ataques e Ruiva (que adquire aspecto demoníaco) se instalar na casa de Lúcia, veremos a derradeira cisão da protagonista com o PCC. O afastamento, que também ocorre literalmente, é concluído com sucesso, mas claro, não sem antes enfrentar antagonistas que adiam a resolução e que são um a um vencidos pela heroína que vai se tornando madura para a ação final ${ }^{23}$.

Com o início dos ataques a paisagem por onde os personagens transitam se torna escura (cresce o número de cenas noturnas) e caótica: congestionamento, transeuntes correndo, lojas fechando e coletivos queimando formam a paisagem do trecho final. Os planos de engarrafamento vistos do alto se assemelham às imagens das diárias reportagens

\footnotetext{
${ }^{22}$ Na terminologia do PCC, "piloto" é uma posição política exercida pelos presos - em especial, os "pilotos" levam as demandas dos presos aos funcionários do sistema carcerário. BIONDI, Karina. Junto e Misturado: uma etnografia do PCC. São Paulo: Editora Terceiro Nome, 2010, p. 111.

${ }^{23}$ Como no esquema da imagem-ação descrito em DELEUZE, Gilles. Cinema 1: a imagem-movimento. São Paulo: Brasiliense, 1985, p. 196.
} 
paulistanas, mas se distanciam do código midiático que impera no filme pela limpeza e pela coloração da fotografia. No congestionamento de carros e na confusão de transeuntes correndo vemos Lúcia que, em meio ao caos, tem que colocar em prática a ação que permitirá que ela e Rafa escapem dali. O engarrafamento criado pelos ataques e boatos é vitoriosamente percorrido por Lúcia que irá subornar um policial para soltar o filho e atirar em Ruiva que tentara lhe enforcar. Ao fim do filme, após resgatar Rafa, mesmo sem destino, os dois seguem o trânsito e partem para longe do pandemônio urbano e da perseguição da polícia que rastreia Ruiva e executa jovens para reverter o "placar" de mortos entre policiais e cidadãos. Fechando o longa, com um banal diálogo familiar, Lúcia e Rafa reestabelecem a união e continuam o trânsito, se afastando da confusão urbana.

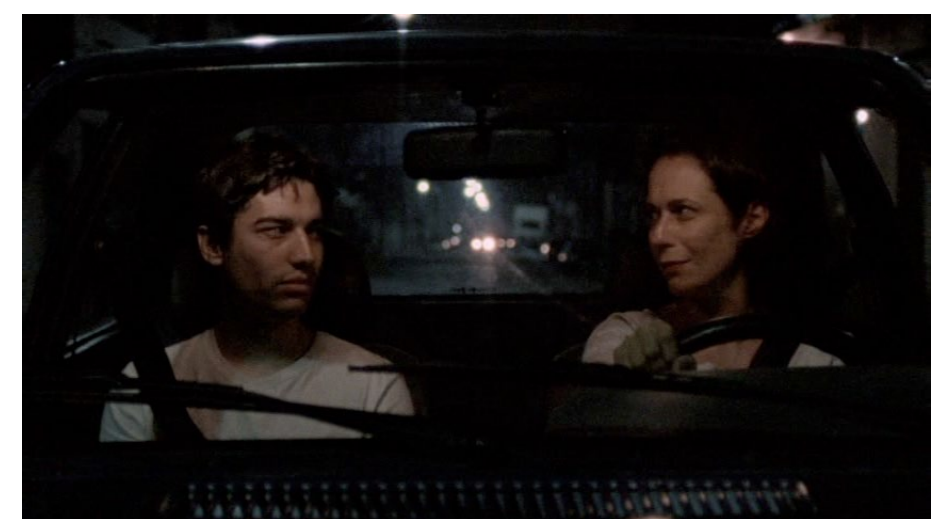

Figura 43 - plano e diálogo final de Salve Geral:

Rafa: mãe?

Lúcia: o quê?

Rafa: para onde a gente vai?

Lúcia: não sei.

Rafa: tô com fome

Figura 43

\section{Após a fala de Rafa, Lúcia abre um sorriso que sugere 0 restabelecimento da harmonia familiar.}

O constante trânsito dos personagens cria uma cidade gigante e também plural. A estrutura do filme entre ações que correm em paralelo também aumenta o senso da imensidão e pluralidade da cidade, pois com os cortes saltamos para ambientes distintos: do presídio ao galpão, do salão à cela, da loja de pianos à casa do juiz, da casa de Lúcia ao centro. Se os muitos espaços exibem a segmentação social e geográfica, os personagens 
não se limitam a permanecer em apenas um núcleo, mas circulam por todos. A cidade percorrida pelos personagens é composta tanto por localidades centrais e conhecidas (Avenida Paulista, praças Roosevelt e da República), quanto por espaços menos conhecidos ou inventados (como o ficcional Jardim Copacabana para onde se mudam, a fachada do presídio onde Rafa permanece detido e a região do salão-célula de Ruiva). Lúcia é levada por Ruiva para bairros pobres, como a região repleta de autoconstruções com materiais precários por onde circulam no início da aproximação entre as personagens.

A mudança da família para a periferia inaugura também o sentido horizontal do deslocamento que será mantido em todo o longa. Após a descida do piano, a mise-en-scène dos personagens percorrendo a cidade é essencialmente horizontal. Apesar dos diversos planos aéreos que marcam o filme e que serão comentados a seguir, muitas vezes as imagens do alto reiteram a horizontalidade da cidade ao enquadrar malhas viárias que se estendem na imensidão do urbano. De cima a câmera também irá achatar a personagem que se torna minúscula e se move pelas ruas.
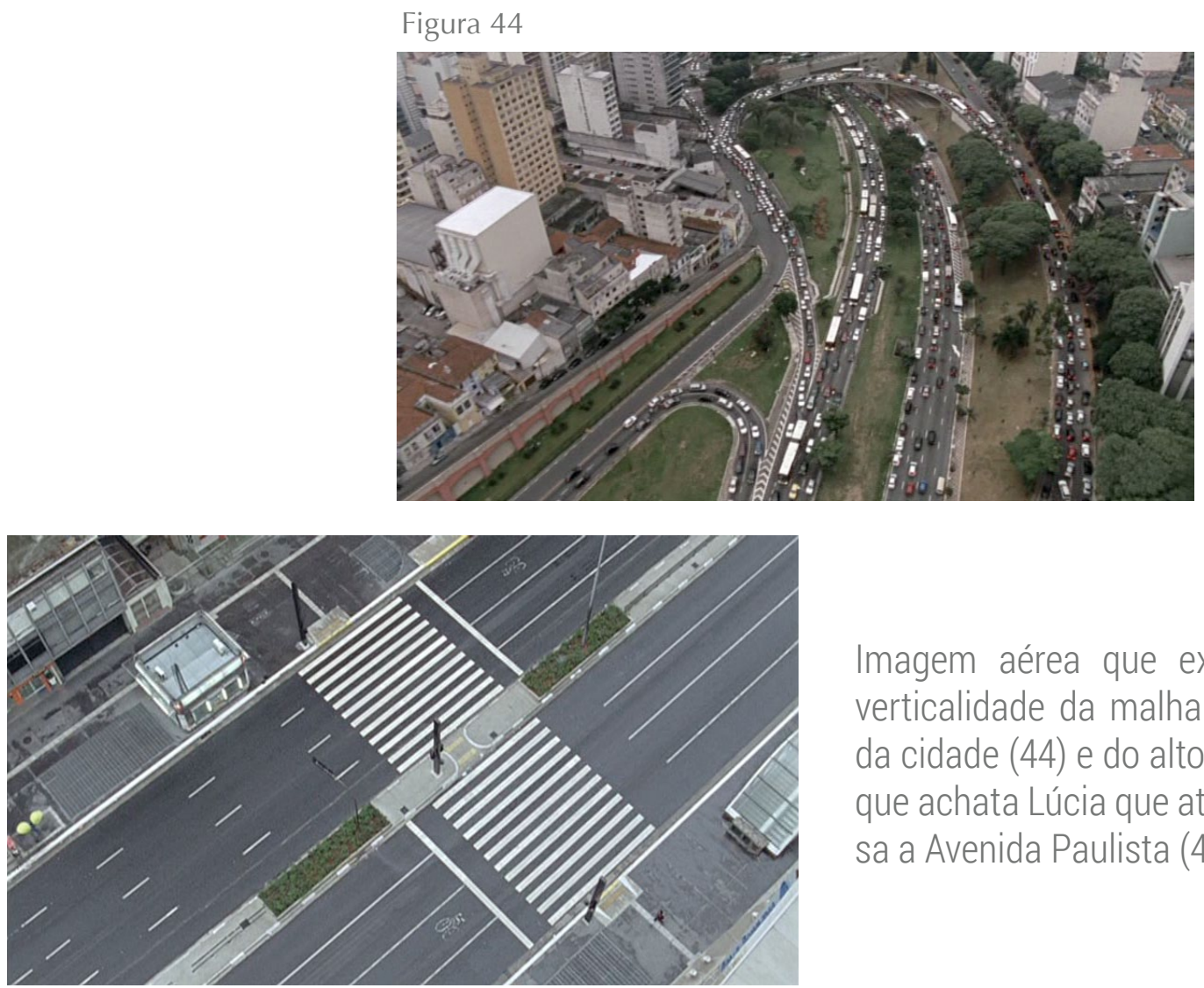

Imagem aérea que exibe a verticalidade da malha viária da cidade (44) e do alto plano que achata Lúcia que atravessa a Avenida Paulista (45). 
A São Paulo de Salve Geral é, em grande medida, a cidade do trânsito, do deslocamento horizontal entre espaços diferentes e contrastantes. Todavia, mesmo com os inúmeros viadutos que figuram ao longo dos deslocamentos, o filme não constrói algo semelhante à cidade-arquipélago de Invasor, comentada na introdução: aqui, como Giba e Anísio de Invasor, os personagens são os temidos, não os que temem. A cidade é palco dos ataques, os presos tomam as ruas que, com o apavoramento da população, são exclusivamente deles e dos policiais. Após saírem com o indulto do Dia das Mães, Rafa e Xis permanecerão no espaço público da rua, mas basicamente dentro do carro (durante a onda de ataques os personagens chegam a dormir no veículo).

Além de ser o cenário dos múltiplos deslocamentos, a cidade é também espaço de algumas permanências e, por vezes espelha o estado interno dos personagens e também a evolução da narrativa. Além do constante ir e vir, em alguns momentos há uma forte interação entre a paisagem urbana e a crise que os personagens enfrentam que, com o eco no cenário, tem sua dramaticidade reforçada (figuras 46 e 47).

Fora das ruas, São Paulo é construída pelas residências (casa de Lúcia e apartamento da irmã), pela "célula" do PCC acoplada em um salão de cabelereiro e pelos pátios, celas e setores administrativos das cadeias. O presídio carioca Frei Caneca forneceu o cenário para a principal cadeia da trama, onde Rafa e as "lideranças" do PCC permanecem detidos e onde muitas cenas acontecem. A escolha de filmar em um presídio desativado em outra cidade, ao invés de reconstituir o presídio em cenário (como em Carandiru), é defendida pelo diretor que acredita que, aproveitar o cenário real do presídio, "altera profundamente o trabalho, porque somos seres humanos sensíveis. A cela de Rafa, por exemplo, tem a parede inteira com pinturas de armas. Ali, a realidade é mais poderosa que a imaginação" e "ainda que o talento dos cenógrafos seja capaz de reconstruir aquilo tudo, no estúdio falta essa matéria sutil da própria vida" 24 . Essa intenção de deixar o que chama de "matéria

${ }^{24}$ Disponível em: <http://cinema.uol.com.br/ultnot/2009/03/12/ult4332u1036.jhtm>. Acesso em: 25 jul. 


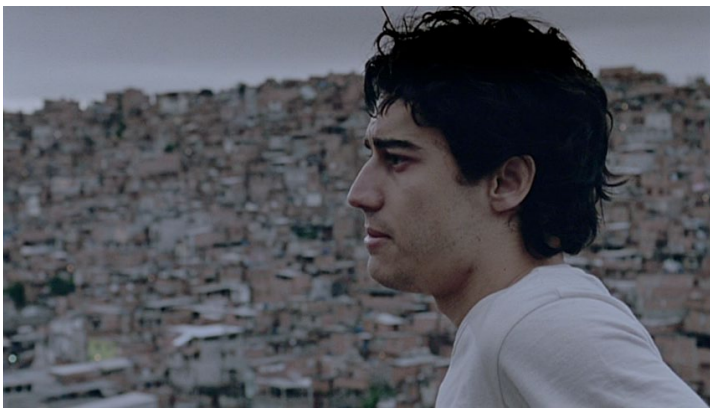

Após o primeiro dia dos ataques Rafa fuma em silêncio, encarando e sendo encarado pelo vasto morro coberto por casas. Ao lado, Lúcia, após discutir com a irmã, caminha na deserta Avenida Paulista.

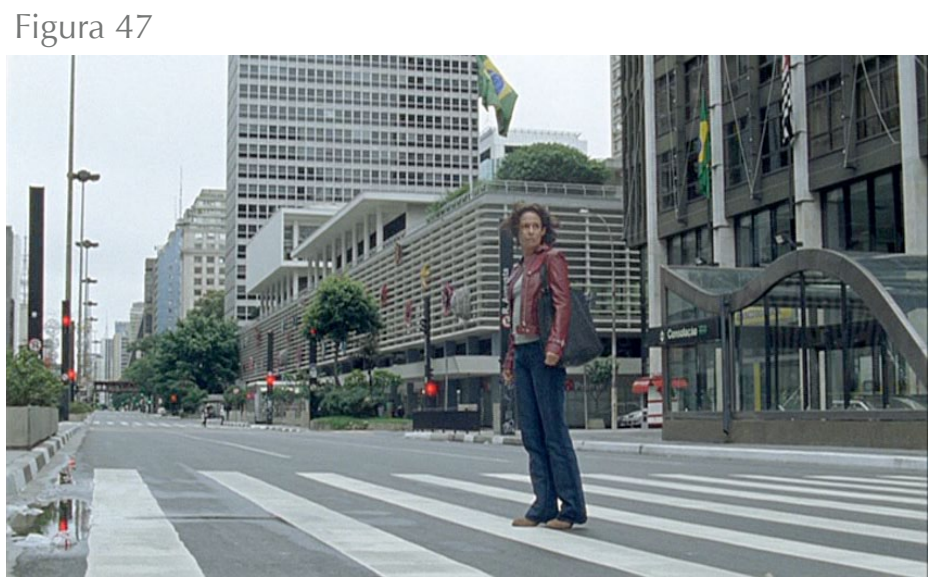

sutil da própria vida" presente nos cenários reais é abafada pela intensa afiliação do filme com os preceitos do cinema clássico - convenção em que a "própria vida" abordada parece estar em segundo plano ao ser lançada em sua rígida fôrma.

Contrastando com a busca do diretor pelo "cenário real" acima referido, locações de Campinas e Paulínia formam grande parte da cidade de São Paulo construída na ficção. Nas ruas, além das cenas de perseguição e ataques, as paisagens genéricas de muitas ações parecem ter sido filmadas no interior paulista. Nos cenários internos, a casa de Lúcia foi construída em estúdio e a antiga sede da Prefeitura de Paulínia se tornou banco, delegacia e hospita ${ }^{25}$. A discrepância entre a importância do cenário real do presídio e o cenário de São Paulo (em parte) construído pode apontar que, para o diretor, em sua imensidão a cidade não tem uma identidade. Apesar dessa possível interpretação de que o filme aposte na identidade genérica da cidade, o longa demonstra uma preocupação de autentificar a São Paulo da ficção - preocupação desnecessária, pois de fato o múltiplo-cenário é eficiente

\footnotetext{
2013.

${ }^{25}$ Além dos extras veiculados junto ao DVD de Salve Geral, a referência ao cenário é mencionada na reportagem disponível em: <http://cinema.uol.com.br/ultnot/2009/03/12/ult4332u1036.jhtm>. Acesso em: 19 ago. 2014.
} 
na construção da pauliceia. Através dos marcos da cidade e dos planos aéreos, coerente com o conceito de transparência, o longa busca a "direção de arte invisível"26, isto é, uma direção de arte que não pareça construída, mas sim como elemento que já estava lá, que precede e independe do filme.

Além dos locais emblemáticos da cidade que figuram no filme (como Avenida Paulista, Banespinha, Praça da República), os inúmeros planos aéreos parecem muitas vezes cumprir a função de construir uma unidade à multiplicidade de locações. Se algumas vezes os planos aéreos surgem com o deslocamento, mais ou menos dramático das personagens, em outras eles aparecem para sinalizar a mudança de cenário nesse universo urbano. Como planos genéricos, as tomadas aéreas não têm um sentido geográfico no longa. Por exemplo, após voltar da cadeia onde não encontra Rafa (que teve que servir à facção), Lúcia para no corredor de sua casa e sua imagem se funde com vista aérea da cidade. A seguir, passamos para a cela onde presos passam o "salve". O plano aéreo (que reaparece em outra sequência), não expressa muito em termos de localização ou de deslocamento, não

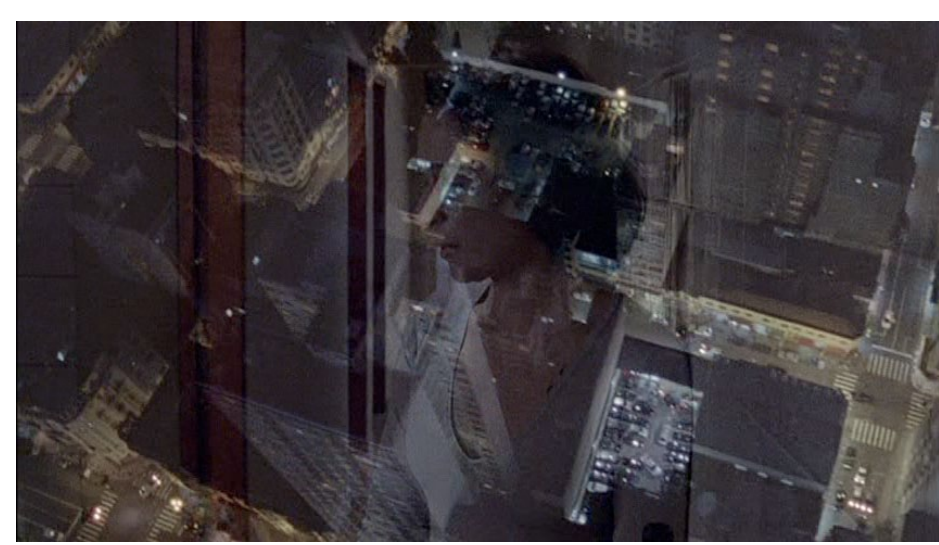

Figura 48

Plano aéreo genérico - 0 mesmo plano aparece unindo espaços distintos na trama.

identifica qual lugar esse plano

sobrevoa e não constrói uma relação que aponte que saímos do espaço "a" (casa de Lúcia que fica em tal bairro) rumo ao espaço "b" (presídio situado em tal localidade). Como um plano genérico, essa vista retorna conectando cenas que se desenvolvem em outros

\footnotetext{
${ }^{26}$ A definição é trazida por Ludmila Machado no desenvolvimento de sua tese de doutorado (intitulada "O Rio de Janeiro no cinema: apropriação e construção da imagem na cidade") - pesquisa em andamento no programa de Pós-graduação em Meios e Processos Audiovisuais (ECA- USP).
} 
espaços (a delegacia e salão-célula de Ruiva), novamente reforçando o espaço de São Paulo construído no filme. Assim, as múltiplas cidades-locação (São Paulo, Paulínia, Campinas e Rio de Janeiro) compõem a São Paulo do filme que convence como sendo uma cidade só.

\section{Salve que não ressoa (ou convenção que pouco convence)}

Se pelo título (e mais especificamente pelo subtítulo) poderíamos supor que Salve Geral se centra no "dia que São Paulo parou" - nos primeiros minutos já revemos essa premissa: trata-se do drama de Lúcia e Rafa, desencadeado pela prisão do jovem que os leva para junto do PCC. Trata-se de uma reconstrução daquilo que antecede os ataques e também de sua evolução que é bastante pautada pelo que foi narrado pela mídia. Como veremos em Inversão, Salve Geral também se cola nos ataques (que aqui aparecem ao longo de todo o filme). Em ambos os casos a abordagem dos ataques sugere a possível intenção de adquirir um pouco da (enorme) visibilidade que o evento teve. Em Salve Geral, como em Inversão e nos exemplos cariocas de Ônibus 174 (José Padilha, 2002) e Última parada 174 (Bruno Barreto, 2008) - que tratam do sequestro do ônibus no Rio de Janeiro -, a tentativa de reconstrução de evento midiático através das produções para o cinema não se realiza plenamente. Nenhum dos filmes chegou perto do impacto do evento a que se referem. Diferentemente das repercussões intensas das reportagens, o pouco impacto desses títulos incita a hipótese de que, excessivamente noticiado, o evento possa ter tido sua força esgotada com a cobertura midiática. Mesmo criando o que a mídia não captou através das cenas de ação, Salve Geral não conseguiu recuperar a força das ações.

A incursão para dentro do PCC guiada pela família da classe média gera uma estranheza. Muitas podem ser as razões para isso, mas a multiplicidade de cenários e elementos da trama apontados como inverossímeis (como a professora de piano que se 
apaixona pelo presidiário ${ }^{27}$ não parecem figurar com importância no rol de razões. De modo inverso, a relação mimética com aquilo que surgiu na mídia parece ser um dos elementos que enfraquece o filme. Isto é, justamente a pouca inventividade da trama, que se pretende verossímil (uma verossimilhança que tem como parâmetro a mídia), é o que faz com que o "salve" não ressoe, "não cole".

Para além da verossimilhança da trama, o filme nos apresenta um retrato que oscila entre uma caricatura dos policiais, da classe média e dos presos (caricaturas marcadas pelos exageros nos trejeitos, gírias e sotaques paulistanos e cariocas). Fora Lúcia e Rafa, o filme vai pouco além dos dados que lhe inspira. Muitos eventos da trama ecoam em eventos noticiados: a emboscada feita pela polícia em São Bernardo do Campo que resultou na execução de treze suspeitos (em junho de 2006), a exoneração do Secretário de Presídios de São Paulo - que, como D'Ávila, não quis negociar com os presos e a ameaça de bomba no aeroporto - boato espalhado por Ruiva após a trégua dos líderes (que no mundo real também se confirmou como boato após a primeira onda de ataques - em 16/05/2006). Além dos eventos da narrativa, a relação mimética do filme com as reportagens é exaltada no subtítulo: a expressão "o dia que São Paulo parou" ressoou em jornais e telejornais como no caderno especial intitulado "guerrilha urbana", que em letras garrafais anuncia "Medo de ataques para São Paulo" (publicada pelo jornal Folha de São Paulo, em 16 de maio de $2006^{28}$ ). Fundamentado principalmente na mídia, o que Salve Geral nos traz é o caos, o pânico, lugares comuns das reportagens.

Diferente do processo de realização de Cidade de Deus, Tropa de Elite e Invasor, para construir um filme que submerge no universo dos presos, Salve Geral não busca o ponto de vista dos detentos nem através da pesquisa que origina o roteiro, nem na estruturação do

\footnotetext{
${ }^{27}$ LOPES, Laura. Os sete erros de "Salve Geral". Revista época (on line), 18 out. 2009. Disponível em: $<$ http://colunas.revistaepoca.globo.com/menteaberta/2009/10/08/os-sete-erros-de-salve-geral/>. Acesso em: 10 jun. 2014.

${ }^{28}$ Página C1 disponível em: <http://acervo.folha.com.br/fsp/2006/05/16/15/>. Acesso em: 20 jun. 2014.
} 
filme. Além da construção dos ataques e da facção pautada pelas notícias e reportagens que são apropriadas numa relação mimética, Salve Geral se distancia do universo carcerário a partir dos personagens centrais e também da forma fílmica. Somos introduzidos e guiados ao universo do crime através dos personagens de classe média externos ao PCC que se inserem nesse meio em decorrência da decadência. Assim, Lúcia e Rafa passam a partilhar o espaço, a conviver (e no caso dela a flertar) com esse "outro" (presos e criminosos). Mas a distância entre eles se mantém e, assim que possível, Lúcia e Rafa se distanciam. A desigualdade entre classe média e presos é reforçada pelos inúmeros privilégios que Lúcia e Rafa encontram ao longo da narrativa: ela não passa pela revista íntima, rapidamente encontra ajuda de Ruiva, e se reestabelece no campo financeiro e afetivo; diferente de Xis, Rafa é poupado da execução e, mesmo sem ter direito, consegue o indulto que, como a fuga do hospital, é obtido através do suborno financiado por Lúcia. Assim, se as classes estão em relação, essa relação permanece pautada pela desigualdade.

A forma fílmica também reforça a distância com o universo carcerário. Fortemente ligada à Lúcia, a clássica música-tema e também as trilhas originais (como "Presos sendo transferidos" - que se associa ao universo cinematográfico, aos soundtracks) reforçam a intensa conexão do filme com o universo da classe média, do qual os realizadores também fazem parte. Apesar do diretor ressaltar sua descoberta sobre a presença feminina no universo carcerário (mencionada na introdução), de modo curioso, Lúcia não pertence à ele, mas, como os realizadores, vem de fora e, seguindo o modelo do cinema clássico, vai se transformar, reagir e modificar a situação em que é lançada.

Junto com os personagens, o filme adota também a postura da classe média - não em sua forma mais reacionária, mas uma classe média atomizada, um tanto indiferente que, nas palavras de Lúcia, "não quer ser juiz de nada". Colado no drama da narrativa, como Lúcia, o filme esboça um discreto posicionamento sobre o evento como se também buscasse se esquivar do julgamento, que inevitavelmente produz. Ao fim, diferente dos 
anônimos executados pela polícia para "reverter o placar" de mortos, como que em um "salve-se quem puder", apenas Lúcia e Rafa escapam.

Ao inserir as personagens de classe média no universo do crime, junto ao PCC, o filme aponta que está "tudo dominado" e nos recorda que, se nenhuma prática criminal pode ser compreendida isoladamente, a facção ou o crime-negócio - que lida com o comércio ilegal de drogas e armas, muito menos. Sua prática envolve muito mais figuras que apenas os detentos, pois atravessa todas as classes sociais e é vinculada a negócios lícitos e ao governo, passando, por exemplo, por “(...) fazendeiros, empresários dos setores imobiliários e de transportes, comerciantes ao longo das rotas de distribuição de seus produtos ilegais até funcionários do sistema de justiça encarregados de reprimir tal atividade econômica ilegal, porém muito lucrativa."29

Todavia, o comentário é abafado pelo drama: Lúcia e Rafa se aproximam da facção por uma fatalidade e, assim que possível, se afastam do PCC e de seu universo. A relação da família de classe média com os detentos é pontual, submetida ao seu drama. Em Salve Geral parece não haver real interação entre os protagonistas, meio e conflito (ataques) em que são inseridos. Apesar do contato intenso, Lúcia e Rafa permanecem estranhos ao ambiente carcerário do início ao fim. A amizade com Xis é marcada pelos "olhares tortos" de Rafa, e pelo fascínio e devoção do amigo ao PCC; a relação amorosa de Lúcia se dá justamente com o detento mais afastado e que só se relaciona com ela, o Professor, personagem que se destaca do universo prisional que é criado no filme. A prisão de Rafa e os ataques fornecem o conflito que impulsiona a trama, motivam as cenas de ação fervilhantes, mas não se impõem sobre a estrutura rígida da narrativa que poderia ser lançada sobre algum outro conflito ligado a outro grupo que não o PCC (as Farcs, o Taliban, Comando Vermelho), sem grande prejuízo ao funcionamento da trama.

\footnotetext{
${ }^{29}$ ZALUAR, Alba. Paradoxos do crime-negócio global no Brasil. In: FLEURY, Sonia; SUBIRATS, Joan; BLANCO, Ismael. Respostas locais a inseguranças globais: inovação e mudança no Brasil e Espanha. Barcelona: CIDOB, 2008, p. 152.
} 
A evolução do drama (família que tem que se habituar ao ambiente do crime, a mãe que se sacrifica pelo filho que ao final é salvo por ela) no fundo não é profundamente marcada pelos ataques e pelo PCC, mas se impõe sobre o cenário e sobre os eventos.

Como contraponto a Salve Geral, que se constitui como drama familiar em torno de um evento real que fornece o conflito exigido para o funcionamento do roteiro, além de Inquilinos que trata dos ataques a partir do cotidiano, Se Deus vier que venha armado (Luís Augusto Dantas, 2013) aborda o PCC, os ataques que voltaram a eclodir em 2012 e o conflito entre facção, polícia e periferia. Apesar de ataques e conflito entre PCC, periferia e polícia serem elementos fundamentais, caros à caracterização dos personagens, do ambiente e da trama, eles não são explicitados e não funcionam como o principal leitmotiv da narrativa. Nela, Damião, detento que sai às ruas com o indulto do Dia das Mães, é convocado para participar dos ataques, mas sua ação é interrompida por uma lance menos espetacular e mais corriqueiro: o assassinato do irmão, cometido sem qualquer razão por um policial. O título toma emprestado o nome da música que fecha o filme, composição do grupo Pavilhão 9 (banda que, com seu nome, relembra o pavilhão onde ocorreu o Massacre do Carandiru) - apontando assim, conexões que imprimem em sua forma um pouco do universo que o filme aborda.

Seja pelo ponto de vista da classe média do filme, seja pelas linguagens utilizadas (que oscilam entre o clássico - da decupagem estável à do filme de ação e o distanciamento da mídia), pela trilha original que se alinha à tradição erudita e do cinema, e que é alheia ao evento ou pela colagem com as matérias, o longa pouco convence. Tal como na crítica que recebeu por Canudos (1997), Rezende parece novamente ter produzido um filme que, dando mais ênfase a trama constituída sobre "uma estética bem comportada, cartesiana e previsível" ${ }^{30}$, apostando na força dos elementos que reforçam a conexão do filme com os

\footnotetext{
${ }^{30}$ ORICCHIO, Luiz Zanin. Cinema de novo: um balanço crítico da retomada. São Paulo: Estação Liberdade, 2003, p. 56.
} 
dados do real e informações da mídia pintados com fiel cenografia, deixa o significado do contexto e as implicações sociais em segundo plano.

Nesse sentido, a crítica sobre tramas que pouco bebem do meio em que se passam estão em sintonia com a posição de Nichols com relação ao docudrama. Pela intensa conexão de Salve Geral com os ataques que são reconstituídos na narrativa, podemos pensar o longa na chave do docudrama, definido como um filme de ficção que tem em sua base um evento ou contexto real. Para Nichols, docudramas apenas salpicam a realidade histórica (através de roupas, veículos, locais e figuras conhecidas) para embelezar um mundo imaginado pelo diretor. Nessa lógica, serão problemáticas todas as formas de docudrama, já que o gênero inevitavelmente organizará todos os aspectos da História (desde décor e figurino ao diálogo e ação) para que sirvam à história narrada, esvaziando todo o contexto e implicações históricas que estão submetidos às regras da narrativa ${ }^{31}$. Apesar de ver exagero na visão de Nichols (pois encontrarmos a realidade salpicada até mesmo nos filmes mais fantásticos e surreais e nem todo filme que explicitamente se refere à História irá reduzi-la à história) e do autor parecer considerar apenas docudramas de Hollywood e desconsiderar interessantes casos como Cathy Come Home dirigido por Ken Loach para a BBC - a crítica de Nichols encontra alguns ecos em Salve Geral. Como vimos, Salve Geral não vai a fundo nos espaços (seja cadeia, cidade ou delegacias) e nem aborda os ataques para além do que a mídia noticiou.

Todavia, para além da "base real", a contrapelo, a potente presença da mídia revela uma questão que a consulta nos arquivos de reportagens não fomenta: a relação dos personagens com as notícias. Além de serem a base da pesquisa, as notícias compõem o material fílmico, constroem e costuram as cenas, aparecendo dentro da trajetória dos personagens, motivando e impulsionando ações que se combinam com as notícias; e mais:

\footnotetext{
${ }^{31} \mathrm{NICHOLS}$, Bill. Representing Reality: Issues and Concepts in Documentary. Bloomington: Indiana University Press, 1991.
} 
a mídia opera em sentido duplo, isto é, não apenas se impõe sobre os personagens, mas é também apropriada por eles.

Como uma das vozes do filme, como narrador ou significada pela fala de Raul, a mídia aparece plenamente integrada à narrativa. A despeito do contraste das reportagens com a linguagem clássica, a passagem das notícias para as cenas de ação ajuda a construir o sentido de continuidade entre ficção e notícias, que é estabelecido no filme. A mídia aparece também motivando ações e reações, como uma ferramenta e termômetro para a imagem política e estatal. Essa relação com a mídia aparecerá de outro modo e com outras implicações em Inquilinos que, muito distante desta cobertura e da violência que aparecem com voz e cara (isto é, som e imagem), explicitamente alterando o fluxo da narrativa.

O pouco contágio entre personagens e meio e a centralidade dos ataques são postos de lado no longa que é analisado no próximo capítulo. Em Inversão as características do urbano se prolongam nos personagens e os ataques serão apenas mencionados no início e ao fim da narrativa. Apesar da presença pontual, os ataques serão importantes para construir a cidade e a atmosfera áspera e oblíqua na qual o filme se desenvolve. Longe da estrutura clássica, o constante trânsito dos personagens de Inversão - que se movem sem os nobres propósitos de Lúcia - é um tanto desenganado. 


\section{Capítulo 2}

\section{Inversão}

Dirigido por Edu Felistoque e lançado em maio de 2011, Inversão apresenta o sequestro do empresário Mendonça, que é encabeçado pela dupla de empresários David e Mila. Em paralelo, seguimos a investigação do crime realizada pela Delegada Juliana junto com os policiais Carlão e Ariovaldo. Diferente da centralidade de Salve Geral, os ataques aparecerão como o ponto de partida da narrativa que desloca a dupla policial para a sessão antissequestro. Apresentados por cartela e pela narração de Carlão no início do filme, o contexto dos ataques ou, mais precisamente, a forma como a narração define esse contexto (que será comentada a seguir) ajuda a caracterizar a cidade turva, oblíqua e áspera construída no filme.

Dos três filmes selecionados para esta pesquisa Inversão é o título menos conhecido. Distribuído pela California Filmes, o longa permaneceu em cartaz por um curto período no Cinesesc. O filme teve como filhote mais popular o seriado Bipolar, composto por 12 episódios que foram exibidos pelo Canal Brasil (2010), pelo Sunday TV(2012) e pela Warner (2014). O seriado mantém alguns personagens do longa (como o narrador Carlão) e o cenário de São Paulo, mas em outras feições. Além de ser bastante centrado na delegacia (espaço que, no filme, só vemos o exterior), a série reduz consideravelmente o trânsito na cidade, que aparece um pouco menos inóspita. O seriado - que deve ser lançado em uma versão para o cinema em 2015 (com o título de Insubordinados) difere também da postura mais contundente e abandona as experimentações audiovisuais que vemos no longa.

Em sua construção Inversão combina elementos que remetem ao cinema policial, ao noir, ao videoclipe e também recursos comuns a seriados investigativos - sugerindo, 
por um lado, que pensemos no filme como uma teia de pastiche. Por outro lado, em alguns momentos, nos deparamos com construções bastante singulares que sugerem a proximidade (estética) de Inversão com o cinema experimental, em especial pelo trabalho da câmera (enquadramento e movimento), da fotografia (iluminação, coloração e foco) e também da montagem (que, por vezes, expressa tormentos internos dos personagens). Na elasticidade do termo, o cinema experimental é pensado aqui de modo literal, isto é, um cinema de experimentação formal ${ }^{1}$ que destoa do que é correntemente feito. Nessa concepção a afiliação estética com o experimental é reiterada também pela distância entre Inversão e filmes paradigmáticos da vertente da Retomada que abordam a violência urbana. Além de se afastarem dos experimentos estéticos, os títulos dessa vertente têm sido alinhados ao realismo (ou "novos realismos" e ainda "hiperrealismo" - como o expoente Cidade de Deus chegou a ser associado) ${ }^{2}$.

Para além dos termos classificatórios, no campo da linguagem, a distância de Inversão com Cidade de Deus, Tropa de Elite e seus filhotes é intensa nas cenas de agressão. Nesses momentos, Inversão privilegia o transtorno mental dos personagens, através de um grafismo que não enfatiza a imagem literal. No filme essas cenas se distanciam das imagens que reiteram a ação apresentada de modo fervilhante que, em diversos títulos da Retomada, se tornam ainda mais excitantes através da reprodução da intensidade da tomada por meio da câmera na mão, dos curtos planos e cortes abruptos - construção mencionada na introdução.

\footnotetext{
${ }^{1}$ MACHADO, Jr., Rubens L. R. O Pátio e o cinema experimental no Brasil: apontamentos para uma história. In: CASTELO, Branco \& ALENCAR, Edwar. História, cinema e outras imagens juvenis. Teresina: EDUFPI, 2009.

2 Por exemplo, Ivana Bentes fala do "novo realismo latino-americano" em: BENTES, Ivana. Estéticas da Violência no Cinema. Interseções: Revista de Estudos interdisciplinares, Rio de Janeiro, ano 5, 2003. Edição especial. Feldman menciona o "apelo realista" como tendência geral da produção audiovisual contemporânea em: FELDMAN, Ilana. O apelo realista. FAMECOS, Porto Alegre, nº 36, 2008. Nagib discute os aspectos realistas do filme Cidade de Deus em paralelo ao realismo do livro homônimo de Paulo Lins em: NAGIB, Lúcia. A língua da bala - realismo e violência em Cidade de Deus. Novos Estudos São Paulo, v. 67, 2003.
} 
Ao lado da montagem pouco usual de alguns momentos, Inversão é composto também por clichês, bordões sobre a cidade, o feminino e também de linguagem, com "lugares comuns" do gênero policial que não surgem aqui com a ironia ou como desconstrução, não fazem emergir a crítica ou a "nova imagem", isto é, a imagem-tempo deleuzeana. Alguns elementos do filme recebem uma "mão pesada", como efeitos que se repetem à exaustão. De modo extremo, a imagem do filme é invertida - tornando o título literal ao espelhar a imagem gravada, isto é, colocando o que originalmente estaria do lado direito no lado esquerdo do quadro e vice-versa. Assim, entre lugares comuns, exageros e experimentos, a análise busca pensar quais são os significados construídos a partir dos experimentos formais salpicados nesse filme que, em muitos momentos, irá reforçar clichês e reiterar noções "lugar-comum". Como veremos a combinação de estilos e o espelhamento dos personagens que a trama promove, aliada ao constante trânsito pela cidade, constrói uma São Paulo perturbada que se estende e se espelha também na mata de onde, após a queda do avião, os sequestradores buscarão sair.

Ao abordar o sequestro realizado por empresários, Inversão se aproxima do conterrâneo Invasor (Beto Brant, 2001), cujo foco não exclusivo na periferia e a abordagem de personagens pertencentes a classes sociais diferentes foi notado pela crítica $^{3}$. Invasor e Inversão (e também Salve Geral, que se centra na classe média em decadência) se distanciam assim do recorte que predomina na vertente da Retomada, que aborda crime e a violência urbana, em especial dos títulos cariocas, que com recorrência se concentram em cenários pobres e personagens marginalizados. Como em Invasor, essa conjuntura tangencia a trama, pois aqui são "os bacanas" - como declara o narrador - que vão praticar o crime e atrair a atenção da polícia, da mídia e da narrativa. Também próximo de Invasor, há aqui a negação do modelo heroico maniqueísta em que toda brutalidade do herói é sempre

\footnotetext{
${ }^{3}$ Como por Bentes (2003, p. 6-7) e ORICCHIO, Luiz Zanin. Cinema de novo: um balanço crítico da retomada. São Paulo: Estação Liberdade, 2003, p. 178.
} 
justificada por uma nobre causa. Em ambos os filmes os personagens estão como que contaminados pela podridão que impera na cidade; não há “(...) personagem positivo neste retrato agudo da metrópole e do país. Ninguém é herói ou sequer anti-herói. (...) No final, nenhum 'raiozinho de sol', (...) Não há aplausos, não há lágrimas. Apenas perplexidade"4 com esse quadro de uma sociedade prestes a ruir.

O movimento da narrativa remete a preposiçãolatina circum quesignifica movimento em torno/em volta de. Circum está na raiz de circunferência (do latim circumferentia) e aparece em expressões como circunavegação, que designa a viagem marítima que ocorre em torno de um espaço, seja ele ilha, continente ou a Terra. Do mesmo modo, circum marca Inversão tanto como movimento (trânsito) quanto como forma (de círculo): em contínuo deslocamento por espaços que se repetem, os personagens parecem presos nesse circum na cidade e em torno dela, isto é, na mata que separa o urbano do mar. A circulação não tem sua importância como deslocamento de um lugar a outro, pois praticamente não há pontos de chegada, apenas movimento incessante com pequenas e desesperançosas permanências no bar e no carro.

\section{Circum-cidade-mata}

Inversão começa com uma animação que apresenta atores/personagens através da trajetória de uma bala disparada por um revólver que percorrerá espaços da cidade que se dissolvem na mata. Em alto contraste, as imagens da sequência de abertura são marcadas pela rígida oposição claro/escuro que, com a ausência de tons intermediários, formam densas sombras. Assim como nessa animação, em que a bala conecta todos os personagens da cidade à mata, a narrativa promoverá a aproximação e espelhamento dos dois núcleos,

\footnotetext{
${ }^{4}$ Ibid., p.180.
} 
isto é, dos policiais e sequestradores. A relação é reforçada pela banda sonora que merece breve discussão introdutória, pois, além dos "atores músicos" (Wander Wildner e Túlio Dek), a trilha desempenha importante papel na narrativa.

A trilha sonora, integralmente composta para o filme, foi dirigida pelo músico Diogo Poças e premiada no Brazilian Film Festival of Toronto. No conjunto, as músicas de autorias variadas são bastante ecléticas, passando pelo trip hop, rap, pelas guitarras pesadas e por sons eletrônicos 5 . Aqui, na animação de abertura, a música tema do filme, composta por Diogo Poças e Alexandre Grooves, remete aos sons do estilo trip hop e reforça o espelhamento dos núcleos através dos antônimos associados na letra ("partido e inteiro", "inverso e reverso" e "último e primeiro")

Após a cartela "maio de 2006 - São Paulo estava sendo atacada por uma organização criminosa" o off de Carlão (que dirige à noite pelas ruas da cidade - figura 17) descreve o estado de São Paulo parado pelos "chorumes", como diz: "36 horas ligado, a ordem era toda a polícia na rua (...) os 'chorumes' estavam atacando, botando fogo em ônibus, banco, ‘sentando o dedo' na polícia (...) Autoridade de quatro, sensacionalismo, pânico, clima de terror. Realidade". Longe de caracterizar os ataques negativamente, Carlão complementa: "pra mim esse clima é bom, eu vendo segurança". Nesse trecho, planos relativamente fechados - que deixam ver pouco da totalidade do espaço - exibem fragmentos da vida urbana: pés de transeuntes, veículos, bares e ponto de ônibus abarrotado de passageiros. Essas imagens reforçam o clichê da cidade que não para e contrariam o clima de pânico anunciado pela fala.

A voz do personagem contextualiza os eventos que se seguem. Os ataques do PCC, que constituem a parte central de Salve Geral e penetram no cotidiano da vida familiar

\footnotetext{
${ }^{5}$ A trilha sonora está disponível em: <http://www.felistoquefilmes.com/inversao/Trilha.html>. Acesso em: 16 jul. 2014.

6 "Inverso, reverso, o último e o primeiro/Sou só eu sozinho, não só quem eu sou/Partido, inteiro, refeito, colado, sou só mais um cachorro atrás do próprio rabo" - primeiros versos de "Tema Inversão" música tema do filme (composição de Diogo Poças e Alexandre Grooves).
} 
em Inquilinos, aqui servem como uma espécie de "gancho" para uma trama que sugere a corrupção e a promiscuidade que marcam as relações da elite paulistana e também dos policias, personagens que são aqui equiparados. A sequência se fecha com o letreiro "baseado em alguns fatos reais" e com uma frase que encarna a fala do diretor repetida agora pelo narrador-personagem: "no dia seguinte o meu negócio ia começar a ser prejudicado por outra realidade. Só que essa realidade não vem da periferia não, vem da classe média. Falida"7. Apesar de mencionar a classe média, o alvo da crítica se volta contra a elite, afinal, sequestrado (Mendonça) e sequestrador (David e, possivelmente, Mila) são proprietários de empresas.

O filme é integralmente estruturado em montagem paralela que alterna mata (onde os sequestradores irão cair) e cidade, onde os policias investigam o crime. Antes de consumar o crime, a preparação do sequestro também surge através de ações paralelas entre os sequestradores. Mila aciona David e os demais membros do grupo: Luís, personagem relativamente agressivo e viciado em cocaína, e Marcão - que, como David, é um dos mais sóbrios. O quarteto se passa por assessores de Bertan, empresário com quem Mendonça se reuniria. O trajeto para o sequestro atravessa uma característica paisagem paulistana: o obelisco do Ibirapuera e o congestionamento da Avenida 23 de Maio (anunciado pela narração de Carlão: "trânsito 'foda', paranoia total"). A tensão do engarrafamento, agravada pelas sirenes da viatura policial que surge atrás do veículo dos sequestradores, é dissolvida quando o carro dos mesmos deixa a viatura passar e então a segue, se desvencilhando assim do congestionamento.

Após escaparem do trânsito, se inicia o rap "Inversão" (composição de Túlio Dek). Vemos então uma pequena sequência que remete a um videoclipe. Parte da letra

\footnotetext{
${ }^{7}$ Em algumas entrevistas, Felistoque declara que sua motivação para realizar o filme foi, em grande medida, falar da classe média que, segundo ele, está falida. Disponíveis em: <http://blogeucinema. blogspot.com.br/2011/05/entrevista-edu-felistoque-fala-de-seu.html $>$ e $<$ http://almanaquevirtual.uol. com.br/ler.php?id=21778\&tipo=1 ?ENTREVISTA+COM+EDUARDO+FELISTOQUE,+DIRETOR+DE+INVE RSAO+\&PHPSESSID=69c8d4c020831 ede4b934893fab7df62>. Acessos em: 26 jul. 2013.
} 
desse rap havia surgido na cartela sobre os ataques ("inverteram o meu mundo, 'tá' tudo invertido, não sei se eu sou ou se não sou culpado"). Mais do que a música tema que aparece na animação inicial, este rap, que será comentado ao final, encarna de modo mais direto uma postura narrativa. O refrão irá repetir algumas vezes "impressionante, como tudo se inverte/ pode ser que eu erre, pode ser que eu acerte" e nas imagens, planos que exibem e reexibem a malandragem dos sequestradores, isto é, seguir a viatura policial para escapar do engarrafamento. Junto à repetição do refrão, a reiteração de um veículo atrás do outro surge com o efeito que dá destaque à sequência de carros (viatura seguida por sequestradores). Do ponto de vista dramático ou narrativo, as imagens expressam pouco e parecem estar mais em função da duração da música que faz coro à crítica proposta por Felistoque, isto é, ao contrário do que supostamente seria esperado, são os empresários que cometem o crime.

Após chegarem ao escritório de Mendonça, o grupo se separa: David e Mila convidam Mendonça para almoçar, Luís mantém o vício no banheiro, e Marcão se passa por motorista e aguarda a todos na garagem. Nesse local, Marcão encontra Ari, seu amigo de longa data e que, por uma infeliz coincidência, é segurança de Mendonça. No banheiro e na garagem vemos as primeiras imagens que, por conta da montagem pouco usual, sugerem a proximidade do filme com o cinema experimental. Tanto o uso da cocaína quanto os assassinatos que Marcão cometerá, privilegiam um estado perturbado dos personagens em uma construção que, longe da transparência e da arte invisível, remetem a uma arte que é visível.

No banheiro, durante pequenos trechos, a montagem salta de um plano para outro, às vezes de um lugar a outro (pia e vaso), produzindo um choque pela quebra de continuidade e compondo uma intensa aceleração na ação - aceleração que remete a videoclipes de música eletrônica (como Omen, do conjunto britânico Prodigy, dirigido por Dugdale). A quebra na continuidade é bastante rápida, cada plano dura apenas um 
frame, e é acentuada por um flash de luz branca, efeito que volta a aparecer quando vemos Luís cheirar a carreira de cocaína sobre o vaso sanitário. Nesse momento o flash branco é lançado sobre o quadro congelado que recebe um sutil zoom in acompanhado de um som metálico. O efeito, formado pelo conjunto de elementos (flash, zoom, still e som metálico) remete a uma espécie de "efeito-destaque" que, comumente, surge em seriados policiais/ investigativos (como o norte-americano CSI) em momentos em que se enfatiza, se destaca uma importante pista da trama. Esse "efeito destaque" foi usado para enfatizar a sequência de veículos da cena-videoclipe, destacando a viatura seguida por sequestradores, e retornará uma série de vezes ao longo do filme.

Na garagem, Marcão mata dois seguranças de Mendonça e terá de assassinar Ari. Como nos demais assassinatos que compõem Inversão essas ações são montadas de modo inusitado. Marcão se afasta do grupo de sequestradores e se aproxima de dois seguranças que estavam em um canto da garagem. Batimentos cardíacos, vozes invertidas, trilha de suspense. Com um flash de luz passamos para o topo da garagem de onde vemos, em curto fragmento, Marcão apontar uma arma contra os seguranças. Os planos, que duram apenas alguns frames, são intercalados com a tela preta e flashes brancos, disparados junto ao som de um discreto tiro - convenção sonora que representa o disparo de uma arma com silenciador. Como na cena do banheiro, em que a alteração promovida pela droga extravasa nas imagens, aqui - de modo mais intenso -, a montagem privilegia o estado subjetivo do personagem em detrimento da ênfase na literal ação, isto é, a agressão cometida.

Ari desconfia de Luís e pede para que todos desçam do carro. Frente a frente, Marcão e Ari apontam suas armas um para o outro. Após o Ações paralelas dos flashback em que revê o momento em que encontrara o amigo, Marcão dispara antes e, com Ari morto, os sequestradores seguem. Matar o amigo marca profundamente o personagem sequestradores no escritório, banheiro e garagem: que caminhará para sua degradação. 


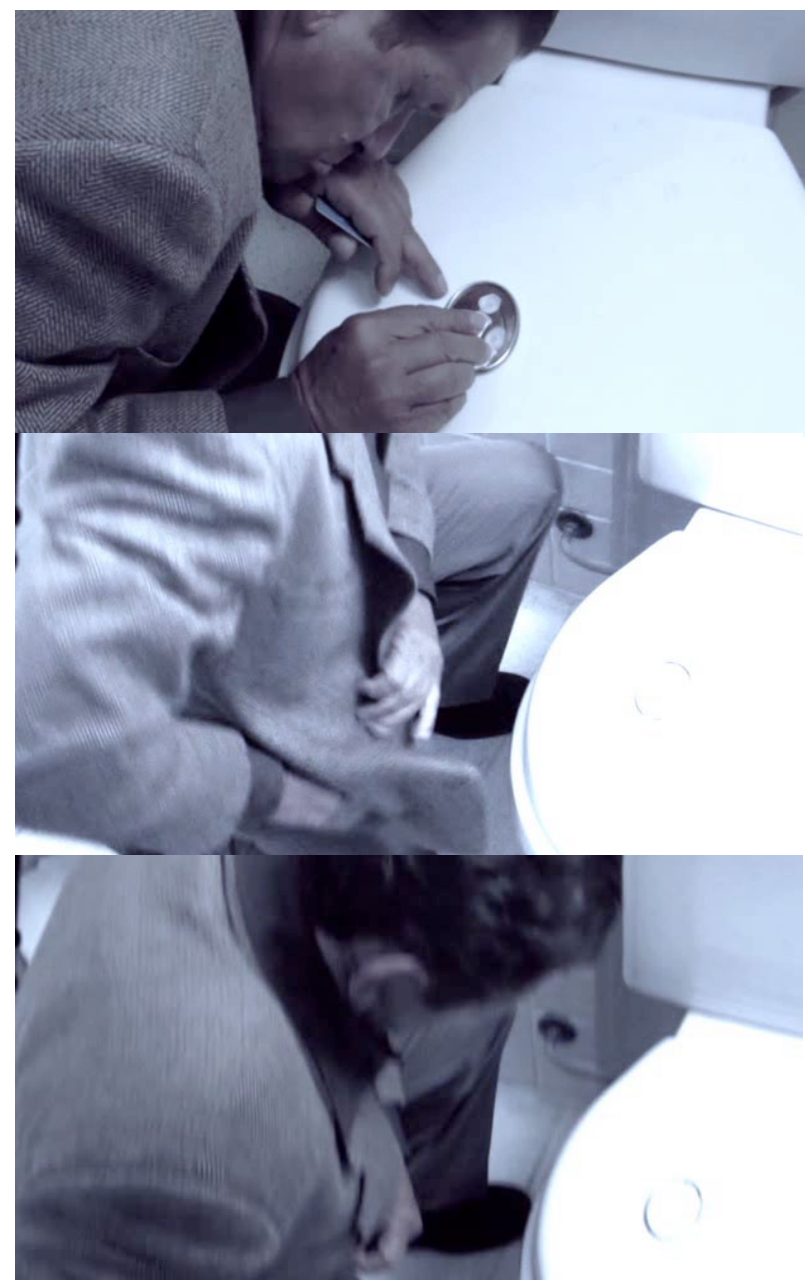

Trecho de descontinuidade entre os planos - cada figura corresponde a um frame que, vistos em sequência, produzem "pulos" entre as imagens - (figuras 1 a 3).

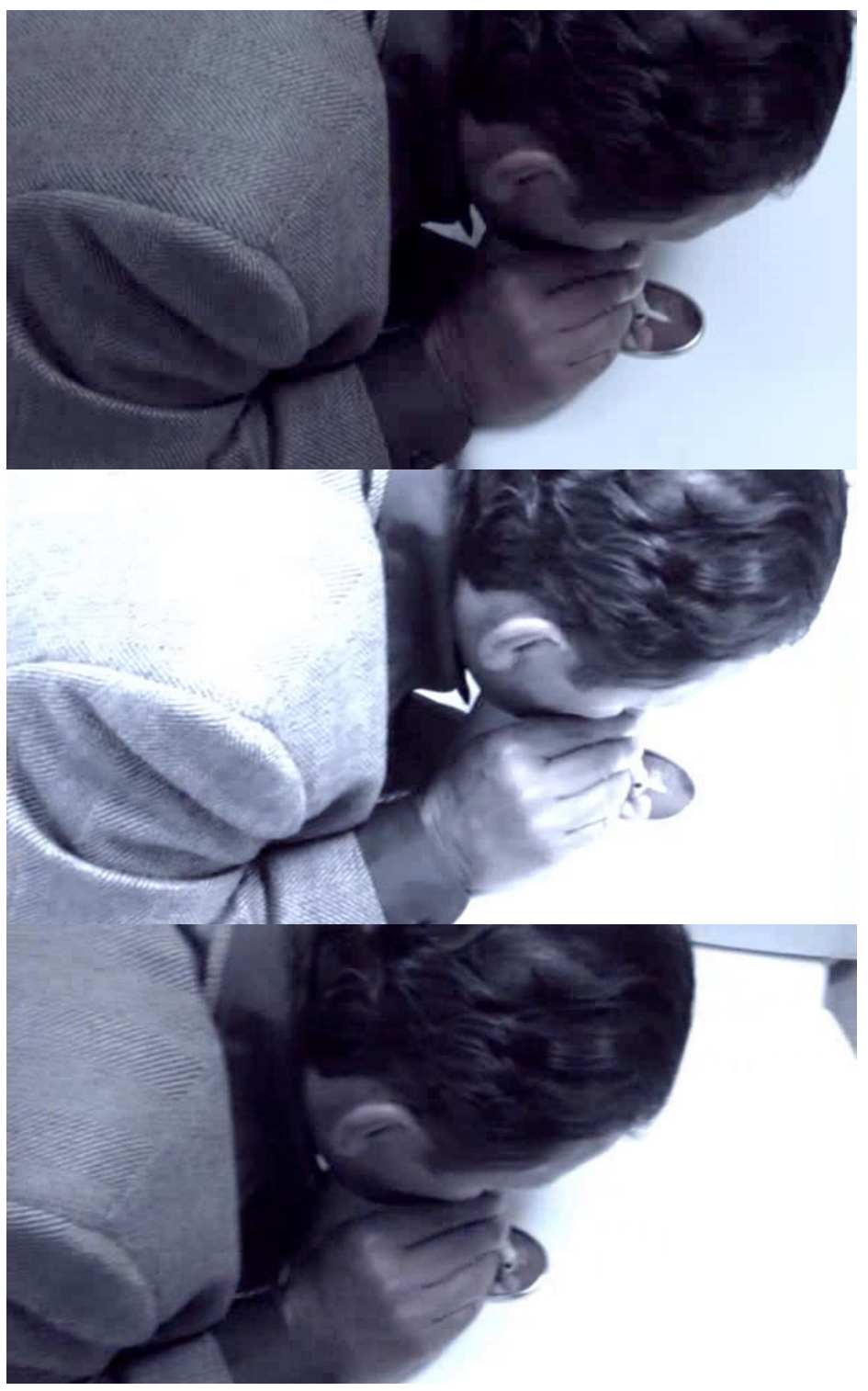

Figuras 7 e 8: com a montagem descontínua Luís "salta" do vaso sanitário para a pia.
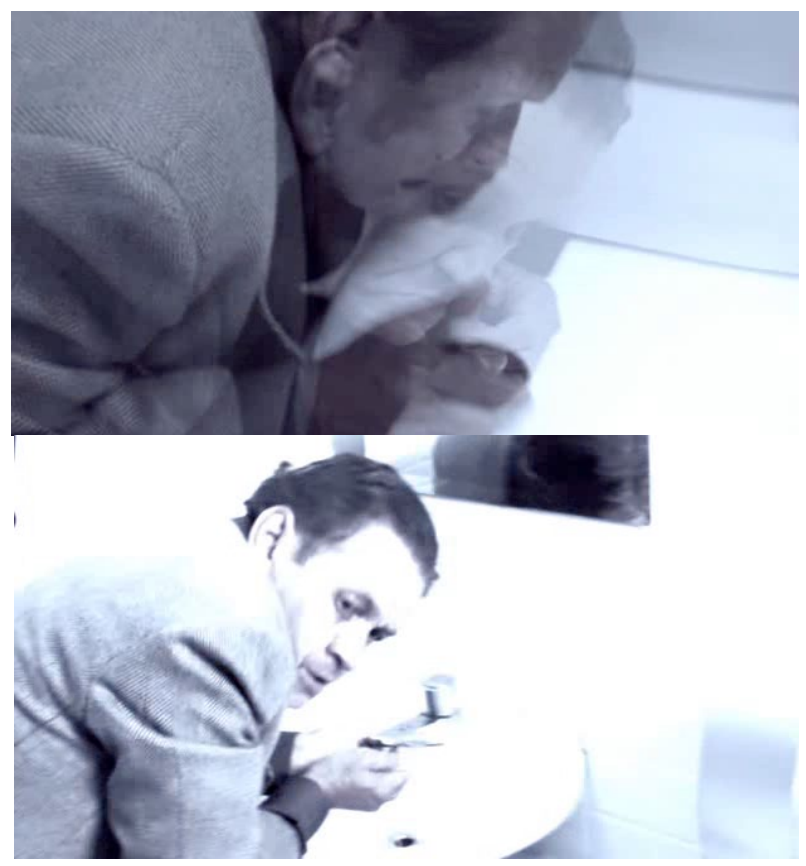

0 primeiro quadro (figura 4) é congelado, recebe Figuras: flash branco (figura 5) e leve zoom in (figura 6).

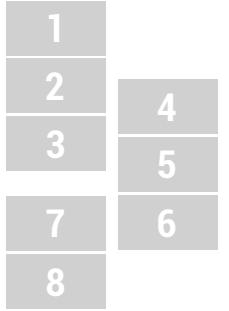




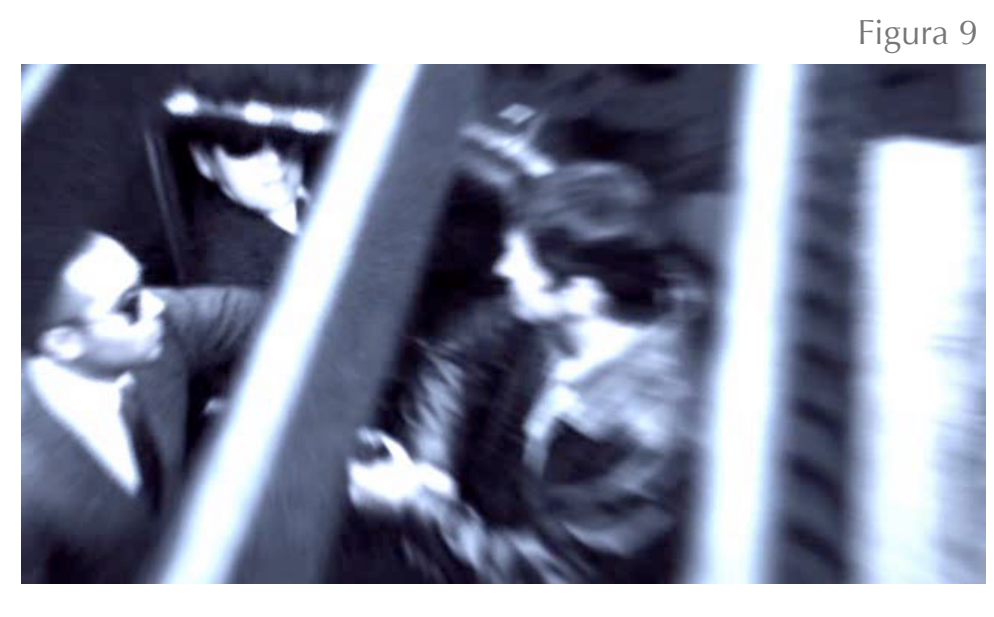

\section{Marcão mata seguranças de Mendonça. 0 plano ao lado é intercalado com tela preta e intenso flash branco.}

O sequestro continua desastroso, mas agora por intermédio da religião. Os sequestradores desistem de seguir para o cativeiro e partem para a pista de decolagem onde o avião os levaria para longe da cidade. Em paralelo, Darcy (namorado de Luís) decide se vingar do adicto amante que desaparecera junto à droga. Darcy e Luís são ligados na narrativa através da corrente com medalhão que ambos usam, objeto que será decisivo na resolução do filme. No terreiro, Darcy faz "trabalho pra danar" e então a montagem alterna planos do avião na chuva e imagens no terreiro: tambores, velas, galinha e batucadas, e com o sincrético chocalho que, junto aos sons vocálicos remete à sonoridade indígena, rimam com os raios e ajudam a construir a queda do avião (o tambor cessa com o raio instantes antes do avião começar a cair).

Após a queda, somos apresentados ao trio policial. Som e imagem de sirene, planos da cidade e então, do bar onde vemos Ariovaldo e a seguir Juliana. "Feio, sujo, mal", assim a trilha que beira o estilo eletrônico (composição de Diogo Poças e Zé Nigro) introduz o trio formado por Carlão, seu parceiro Ariovaldo e pela Delegada Juliana. A jovem delegada que conduz a investigação do sequestro nos é apresentada pelo off de Carlão: "despreparo total na Polícia Civil e, nessa mata de concreto, fez um pouso forçado - como os bacanas [sequestradores]".

A busca pela solução do caso e pela saída da mata que se seguirá durante a maior parte do filme é marcada pela desesperança e hostilidade. Em ambas as trajetórias os 
personagens circulam por espaços que se repetem, ou que se assemelham bastante, e que não apontam saídas ou soluções. Os poucos momentos que esboçam a possibilidade de saída rapidamente se convertem em crises. Na cidade, o trânsito marca a investigação dos policiais que transitam entre avenidas movimentadas e vias com aparências mais genéricas, entre locais mais ricos (edifícios comerciais e interiores da casa e do escritório de Mendonça) e também por espaços mais pobres que abrigaria um suposto cativeiro e onde buscam um culpado. A periferia é caracterizada por planos da emaranhada fiação elétrica, fachadas de casas, janelas e varais que, pela simplicidade, se opõem aos prédios e centros comerciais.

Figura 10

Emaranhado de fios e varal (figuras 10 e 11) elementos que se repetem na caracterização dos locais periféricos.

Abaixo, plano que incorpora o olhar dos transeuntes (figura 12).
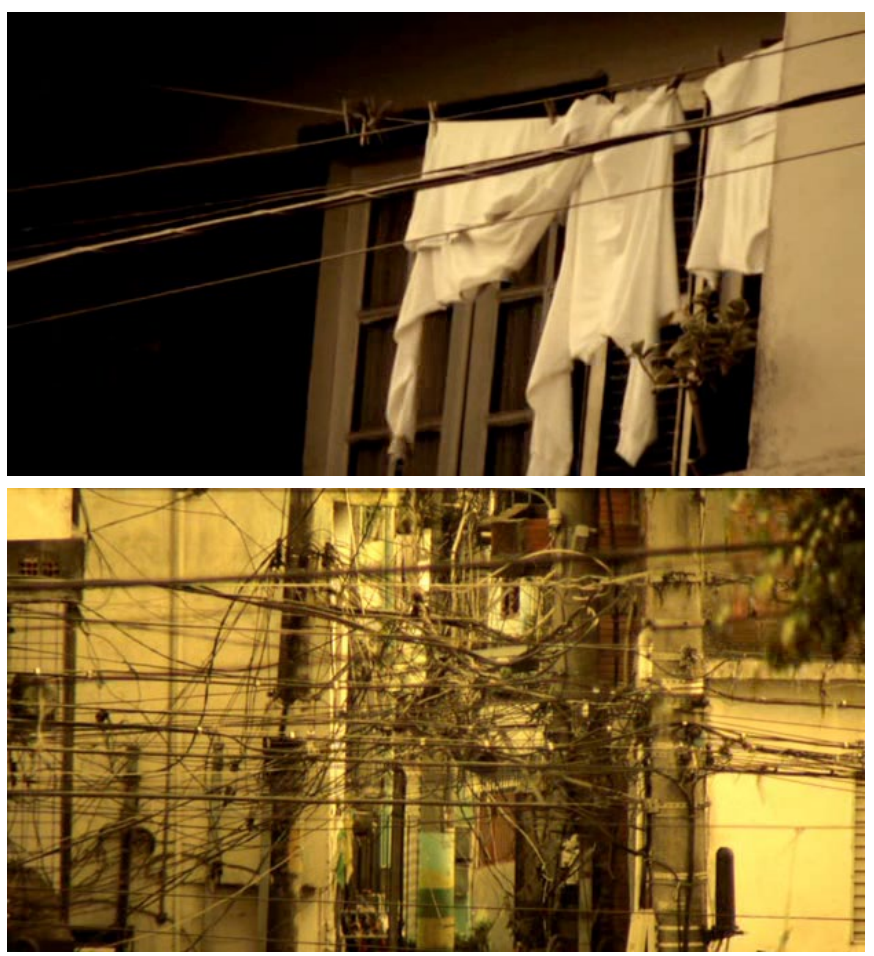

Figura 11

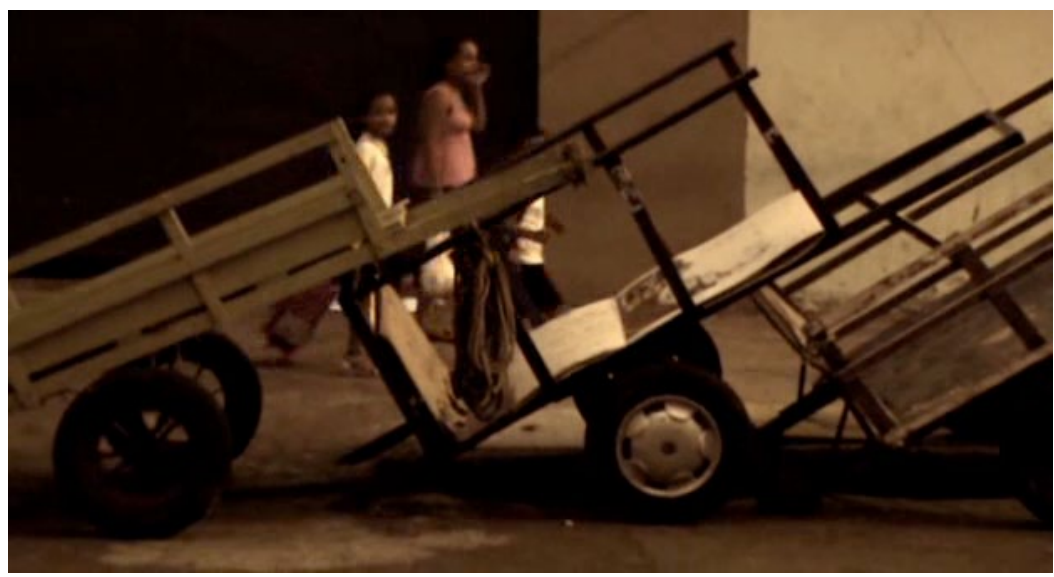


Figura 13

Figura 14
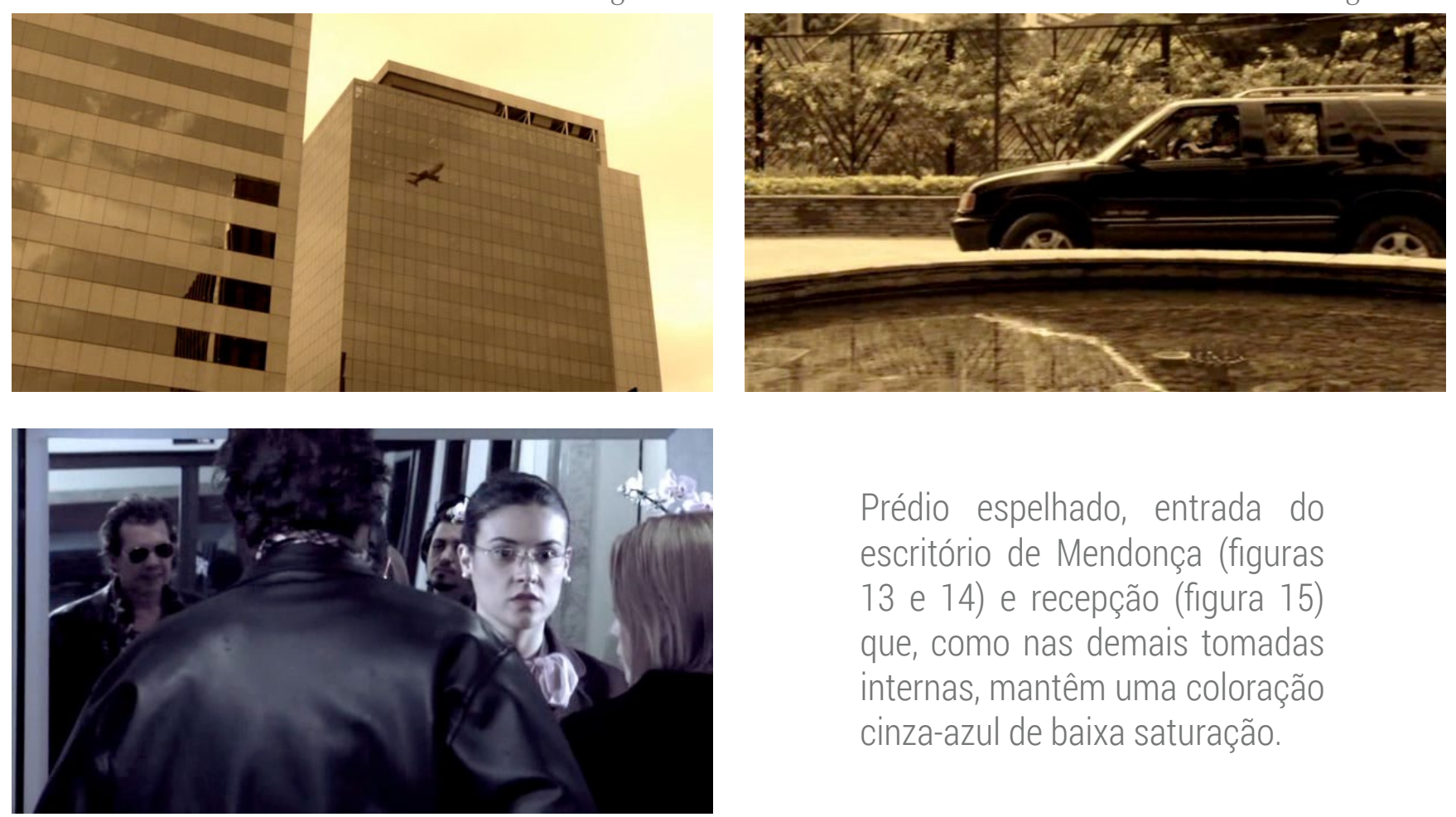

Prédio espelhado, entrada do escritório de Mendonça (figuras 13 e 14) e recepção (figura 15) que, como nas demais tomadas internas, mantêm uma coloração cinza-azul de baixa saturação.

Figura 15

$\mathrm{Na}$ periferia algumas tomadas carregam certo aspecto documental: por vezes os transeuntes olham diretamente à câmera, remetendo a uma relação não orquestrada e certa abertura ao contingente (recurso que é mais frequente em documentários do que em ficções). No cenário periférico encontramos o bar que, assim como o carro, é um dos poucos locais de permanência. Em comum, todas as tomadas externas na cidade e também nos bares têm uma coloração amarelada, às vezes com uma saturação bastante baixa que beira o preto e branco. Contrastando com o calor da tonalidade amarela, nas tomadas internas predomina uma coloração cinza-azul também de baixa saturação.

Na mata, o trânsito desenganado será bastante semelhante. Como em Salve Geral, em Inversão não são os marginalizados que protagonizam o crime. Subindo na escala social, aqui são os empresários que, desde o início da narrativa, encabeçam sem titubear a ação planejada. A elite de Inversão é hostil, se digladia e se entredevora sem sinal de confiança ou solidariedade, seja entre os pares-capangas (que se veem em situação delicada após a queda do avião), seja com Mendonça. A suposta vítima do sequestro que, mesmo conseguindo 
fugir, se junta aos sequestradores e aponta o caminho de saída é, de todos os que estão presos na mata, o único que consegue se manter calmo e sóbrio. De modo curioso, só conhecemos o rosto de Mendonça aos 42 minutos do filme quando ele consegue retirar o capuz colocado pelos sequestradores (figura 19). Antes do sequestro, o enquadramento terá a mesma função do capuz, pois exibe apenas boca, braços e sapatos do personagem, ocultando assim a imagem completa de seu rosto. Ao escapar por alguns instantes dos sequestradores e arrancar seu capuz, Mendonça recupera o pleno olhar (mesmo encapuzado ele espiava através de buraco no tecido) e assume de vez o protagonismo do filme: sabendo manipular o restante do grupo, ele será o único que sairá vivo da mata.

Como Lúcia em Salve Geral, a Delegada Juliana também passará por uma intensa transformação ao longo do filme, mas aqui o sentido de sua mudança é rumo à deterioração. Juliana é literalmente pressionada pelos repórteres que lhe abordam na saída da delegacia e também pelo chefe que quer que ela resolva imediatamente o caso e que irá ameaçá-la em constantes telefonemas. Nesse ambiente, os valores que defende no começo se desintegram. Diferentemente de sua postura no início, quando reprime Ariovaldo por receber propina, e também Carlão que, como ele, age de modo violento, a delegada acaba por se integrar aos abusos dos colegas. O ápice da mudança vem quando Juliana tem um acesso de desespero no carro após ser inquirida de modo sufocante pelos repórteres. Carlão e Ariovaldo buscam "resolver seu problema": encontram um estuprador que assumiria a autoria do sequestro. Juliana é levada a esse homem na mais longa e grotesca cena de agressão do filme: após vomitar e dar um tiro para o alto, ela inscreve com um canivete (rasgando a testa do estuprador) o número 213 - artigo de estupro no código penal.

$\mathrm{Na}$ mata, as relações vão se tornando mais ásperas. Os sequestradores agridem constantemente Mendonça, mas também brigam entre si e alguns personagens vão imergindo no delírio. Além de Luís, que parece afetado pelo vício e pela droga, Marcão não supera o fato de ter matado Ari e é atormentado por inúmeras visões que surgem como 
flashbacks. Por um momento, ao encontrarem o mar, a esperança aparece para o grupo. Todavia, em um anticlímax, a chegada ao mar precipita o desfecho negativo do sequestro. Marcão se agacha sobre as rochas e fita a água; com jaqueta, arma e sapatos, ele pula no oceano para não mais voltar. A desesperança contamina os demais e novamente a religião altera a trajetória da narrativa.

Após o "trabalho" do início, que resulta na queda do avião, Darcy é conectado à trama através da TV, que exibe uma reportagem sobre o sequestro, a qual o incita a procurar Juliana. Na esperança de encontrar Luís, Darcy entrega à delegada a carta deixada pelo namorado que indicaria o endereço do cativeiro. Em um ataque de raiva e na evolução da personagem rumo à aspereza, Juliana repele Darcy: "tira essa 'bicha' daqui". No trecho final do filme, Darcy volta a procurar Juliana e deixa com ela sua corrente para que a entregue a Luís, quando encontrá-lo. Desistindo de revê-lo e também de se vingar, Darcy volta ao terreiro para desfazer o "trabalho" anterior. Em paralelo às velas, à galinha e aos tambores (instrumentos que, como na queda do avião, estendem seu som na ação que interfere), em frente ao mar, Luís obriga Mendonça a colocar sua corrente, abençoando de vez a sorte desse personagem.

Após receber a corrente Mendonça acirra a crise entre os personagens. David e Luís trocam tiros e caem. Pouco antes de morrer, vemos e ouvimos pela primeira vez o estado mental, o passado e as motivações de David através de um flashback em forma de transe que, como um "flashback antes da morte" (moment-before-death flashback), condensa o passado e a memória em uma colagem regida pela força do inconsciente ${ }^{8}$.

O transe se inicia com a repetição de duas falas de Mendonça ("é preciso pedir licença para entrar na mata" e "esse seu pesadelo vai acabar"). Percebemos então que David, que era visto caído sobre rocha em frente ao mar, não está mais na mata, mas sim em um parque (Parque Trianon). Mantendo o circum mesmo durante o transe, David

\footnotetext{
${ }^{8}$ TURIM, Maureen. Flashbacks in Film: memory \& history. New York: Routledge, 1989, p. 52.
} 
caminha por pontos da cidade como o canteiro central da Avenida Paulista e em calçadas movimentadas. Além das fusões e das alterações nas velocidades, as imagens são oníricas: enquanto David anda em direção à câmera, carros e pessoas que habitam o mesmo quadro fazem o movimento contrário, se deslocando em ré, para trás. A paisagem urbana se alterna com trechos dele andando na mata, rostos dos demais personagens e plano em que o transe se iniciou. O off continua e agora nos apresenta pela primeira vez seu passado através de um diálogo imaginário com Mendonça "eu quebrei a mais antiga empresa da família", "eu precisava de dinheiro (...) eu precisava mostrar para a família que eu não sou um inútil...", "como eu pude confiar nelas?". Condizendo com o clima do transe, o que é dito fica pouco claro, em especial pela mixagem que combina diversas falas, sussurros e eco. Continuamos assim alheios ao passado desse personagem.

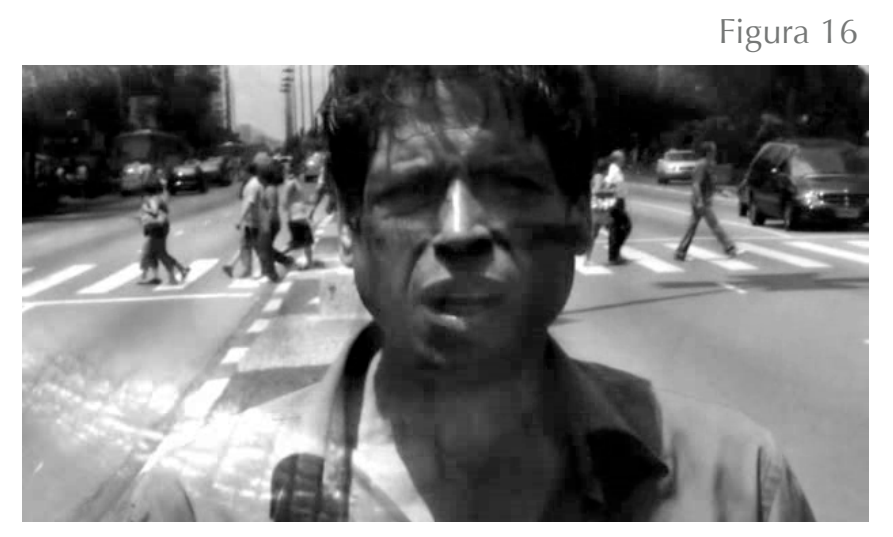

Flashback-transe de David personagem caminha no canteiro da Avenida Paulista. Sobre sua imagem é sobreposto o plano da boca de Mendonça (figura 16).

Entre as diferentes funções desempenhadas, os flashbacks que se avolumam ao longo da trama (ao todo são 19) têm intensas implicações no desenvolvimento da narrativa, apontado a tragédia ou o triunfo dos personagens. De modo curioso, à exceção de Luís, os personagens que terminam bem não têm flashbacks (Carlão e Ariovaldo) ou quando têm, se relacionam de modo peculiar com as lembranças - como acontece com Mendonça. Além de David e Mila - que também terá seu moment-before-death flashback, outros dois 
personagens que declinam (Marcão com a morte e Juliana com o desolo) também são atormentados pelas reminiscências. Matar o amigo, agredir o estuprador, ser ameaçada pelo chefe, ser pressionada pelos repórteres e explodir de raiva, vão assombrando e construindo os estados perturbados dos personagens.

De forma distinta dos personagens atormentados pelos flashbacks, Mendonça se relaciona com certa frieza e de modo calculista com suas memórias: rever as agressões sofridas na mata e sua filha dormindo com Mila não o desestabilizam. Ainda dentre suas lembranças, ele se recorda de uma palestra e de um manual sobre sobrevivência na mata flashbacks que serão os únicos externos à cronologia das ações do filme e que justificam sua escolha por permanecer junto aos sequestradores (o manual diz "a chance de sobrevivência junto à alguém, não importa quem, é muito maior"). As lembranças dão o tom e o caráter das ações de Mendonça: estrategicamente, ele se mantém calmo e consegue se vingar de todos.

Após flashback de Mila, um pouco menos delirante que o de David, Mendonça a mata e atravessa o trecho de mar onde Marcão se afogara. A seguir o vemos sair da delegacia junto ao trio policial. Como ocorrera ao longo do filme, em sequências anteriores, a mídia aparece cercando a saída da delegacia, assediando e sufocando os personagens. No carro com o trio policial Mendonça sorri e conta uma história inventada sobre o desfecho do sequestro, história essa que se torna ainda menos provável quando Juliana percebe que ele utiliza uma corrente idêntica a que Darcy lhe entregara. Contrariando a feição preocupada de Juliana, Carlão abre um sorriso ao ouvir a mentira. Diferente de Juliana, que termina desolada na companhia da corrente e de um copo vazio, Carlão e Ariovaldo, integrados ao esquema da ilegalidade e deveras astutos nesse meio, se tornam seguranças de Mendonça. De volta ao escritório o empresário encomenda a morte de um sobrevivente (Waltinho, interpretado por Túlio Dek) que ajudou no sequestro. O filme se encerra com Mendonça ministrando uma palestra sobre como sobreviver na mata. 


\section{Miscelânea: clichê e experimento}

Em sua construção, Inversão combina clichês e iconografias de diferentes gêneros e formatos, como o policial, noir, videoclipe (descrito no início) e também construções que flertam com o experimental, como as montagens subjetivas e o transe onírico de David. O estilo policial com leve inclinação ao noir é marcado pela intensa presença de duas importantes iconografias do gênero: o carro (onde os policiais transitam) e o meio urbano. Nas primeiras imagens, o motivo - personagem que nos fala em off enquanto dirige pelas ruas da cidade noturna - e a baixa saturação da cor, que beira o preto e branco, remetem à imagens de filmes noir. Ainda, o rosto do personagem visto no retrovisor terá uma aparência ligeiramente deformada em decorrência do pouco foco e pelo intenso contraste claro/escuro (como na figura 17 - em que quase não há meio tom). Os contrastes sobre os rostos que marcam a animação do início aparecem em outros momentos exaltando e exteriorizando o tormento dos personagens em imagens que remetem às distorções do expressionismo - proximidade que será comentada a seguir.
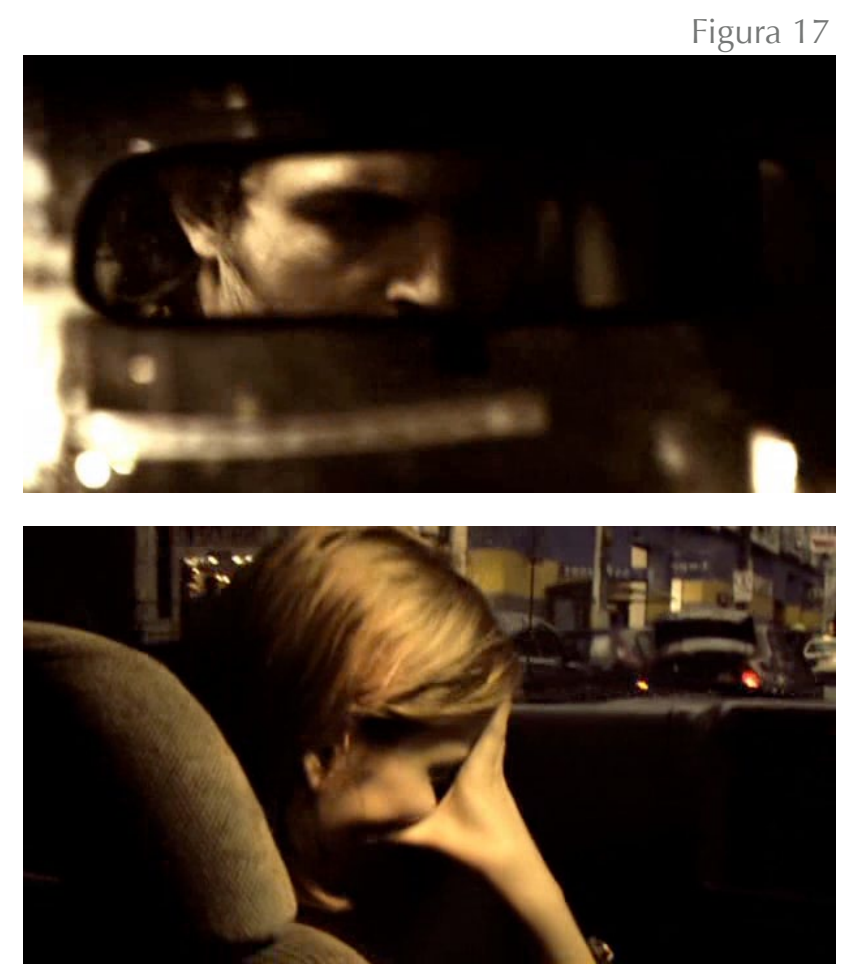

Carlão ao volante no início do filme (figura 17). Aolado, Juliana se desespera pela pressão dos repórteres e do chefe para que resolva o caso (figura 18).

Figura 18 
Mendonça atordoado na mata, no momento em que consegue escapar, e Luís, após a queda do avião (figuras 19 e 20).
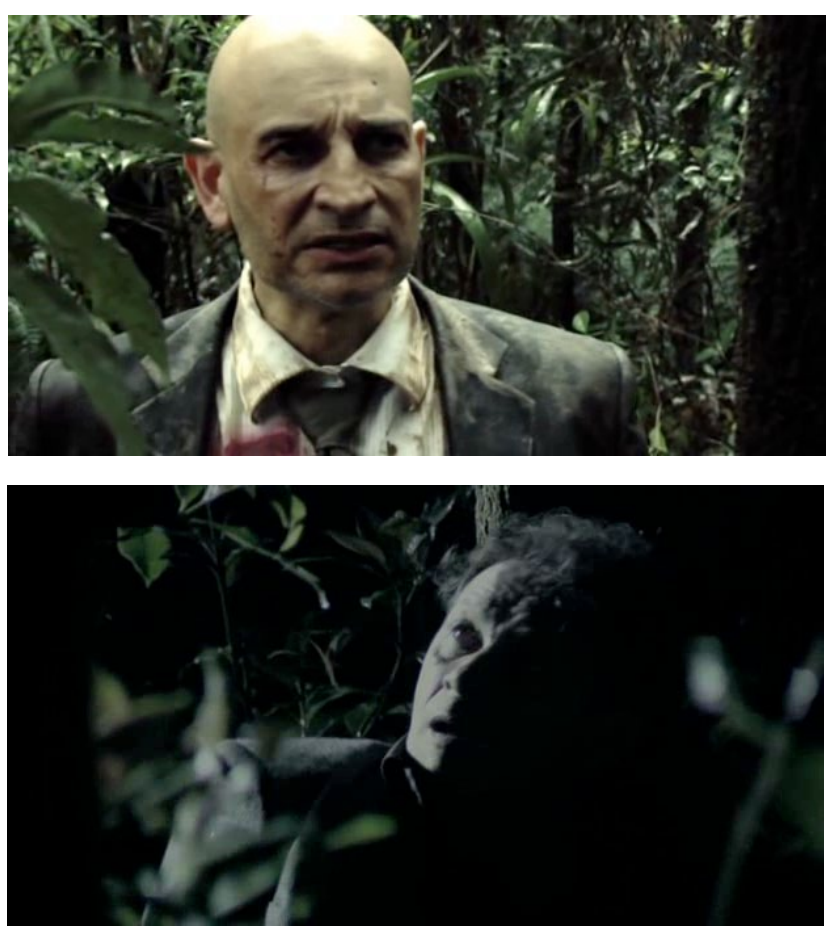

Figura 20

A aproximação do gênero policial poderia ser um dos caminhos para pensarmos nessa referência às sombras expressionistas e também à montagem subjetiva - que pode ser associada ao experimental. Segundo Colin Arthur (1990), nos Estados Unidos o gênero policial funcionou como um catalizador das ideias avant-garde. Com a popularização da teoria freudiana nos anos 30, junto dos filmes noir produzidos no país, muitas tramas apresentam personagens presos em sonhos, pesadelos, histeria e loucura, não sendo raro encontrar exemplos que se aproximam de correntes avant-garde entre os policiais estadunidenses ${ }^{9}$. Mas Inversão vai além, pois não se encerra na aproximação dos gêneros cinematográficos (policial e noir) ou das reminiscências estéticas do expressionismo e do surrealismo. O filme também mistura em seu caldo uma série de clichês entre efeitos que se repetem e lugares-comuns do cinema policial (constante presença do carro, o policial frio, a urbe noturna), da cidade de São Paulo e de gênero (feminino versus masculino). Junto a esses clichês, alguns elementos do filme surgem com certa "mão pesada".

\footnotetext{
${ }^{9}$ McARTHUR, Colin. O filme policial. Lisboa: Horizonte 1990, p. 13; 69.
} 
Nesse sentido, os flashbacks e o "efeito destaque" (descrito na cena de Luís no banheiro e que volta em inúmeros momentos ao longo do filme) são "pesados" e muitas vezes constroem redundâncias. Se do ponto de vista formal podemos dizer que todo filme é a sucessão de fatias de tempo e de fatias de espaço"10 e se a manipulação do tempoespaço (através de elipses, cortes e raccords) é um elemento fundamental no cinema, em Inversão essa manipulação é evidenciada pela montagem paralela, pelo "efeito destaque" (que congela o quadro) e pelo constante uso do flashback. O flashback que, de modo simples, pode ser definido como uma imagem ou um segmento que representa uma ação passada, tem implicações e usos bastante variados ${ }^{11}$.

Em Inversão, encontramos o flashback como ilustração de fala, recordação didática, explicação sobre o passado, "revelação" de incidente e memória subjetiva de um personagem. Em sua maioria, os flashbacks são de baixa amplitude, pois apresentam lembranças internas, que recordam aquilo que se deu dentro da cronologia da narrativa (que dura cerca de cinco dias). Nesse sentido, o retorno no tempo também permanece preso no circum da narrativa, são poucos os flashbacks que extravasam o momento no qual a trama se iniciou.

$\mathrm{Na}$ forma, os flashbacks se diferenciam das imagens do presente narrativo por estarem em preto e branco e, muitas vezes, serão acompanhados do "efeito destaque". Além de aparecerem juntos, flashbacks e "efeitos destaque" são próximos em sua forma e

\footnotetext{
${ }^{10}$ BURCH, Noel. Práxis do Cinema. Lisboa: Editora Estampa, 1973, p. 12.

${ }^{11}$ Entre as principais funções desse retorno do tempo fílmico, encontramos o flashback como a narração de uma história dentro da história (um personagem ou narrador interrompe o desenvolvimento do filme para contar uma história anterior); ilustração de fala (como em diversos filmes de julgamento em que falas dos personagens são acompanhas das imagens que as confirmam); recordação didática (reapresentando ao espectador elementos vistos anteriormente no filme); explicação sobre o passado do personagem; revelação de incidente omitido na narrativa (omissão em geral com objetivo de gerar suspense); e, por fim, a memória subjetiva de um personagem (que traduz um estado emocional, muitas vezes um estado perturbador, beirando ou já como patologia). TURIM, Maureen. Flashbacks in Film: memory \& history. New York: Routledge, 1989.
} 
significado. Ambos os recursos constantes em Inversão lembram os momentos em que se introduz um detalhe revelador da trama nos filmes policiais e nos seriados investigativos (o congelamento do quadro pode ser pensado como analogia à fotografia da investigação). Se esteticamente os recursos que deveriam anunciar uma novidade estão próximos das narrativas investigativas, no campo expressivo, em Inversão eles constroem uma redundância.

O retorno no tempo, o congelamento e a evidência - construídos com ar de suspense pela imagem que perde a cor, para, receber flash e zoom - têm seus sentidos esvaziados ao "revelar", evidenciar e reiterar o que já conhecíamos, informações que, em alguns casos, redundam também no diálogo. Por exemplo, durante a investigação o trio policial encontra o furgão onde os sequestradores fugiram. Após Ariovaldo contar a descoberta para Juliana (novidade para eles, mas não para nós espectadores que assistimos a fuga), revemos a imagem do furgão partindo. Do mesmo modo, anunciando uma novidade, outros flashbacks e destaques reiteram o que já sabíamos: vimos o corpo de Ari ser colocado no porta-malas, sabemos que a filha de Mendonça se relacionava com Mila, que os sequestradores seguem os policiais na Avenida 23 de Maio, que Luís deixou um bilhete para Darcy e que ele entregara sua corrente para Juliana. Assim, a repetição do mesmo efeito ("destaque") e os inúmeros flashbacks que apresentam informações já conhecidas, geram certo esvaziamento das imagens e produz um esgotamento da linguagem que é utilizada à exaustão. Ambos os elementos ("efeito destaque" e flashback) podem ser colocados no rol da "mão pesada" do filme.

Mesmo reiterando e repetindo o que já conhecemos, parte dos flashbacks também aparecem em Inversão com outro sentido. Como memória subjetiva de um personagem, em alguns casos, o flashback não surge para narrar parte da história ou para revelar determinado dado, mas para construir (audiovisualmente) o estado interno dos personagens. Essa construção do flashback como exploração psicológica dos personagens foi e tem sido largamente usada no cinema, aparecendo em momentos bastante distantes, 
como nos melodramas de Griffith e nas vanguardas europeias. Influenciados tanto pelas investigações filosóficas sobre a memória (em especial desenvolvidas por Bergson e Proust) quanto pelos estudos da psicanálise, as obras dos avant-garde se distanciam da representação de um mundo objetivo e se aproximam mais de uma imersão no estado psicológico do personagem - mergulho no qual o flashback tem papel de destaque ${ }^{12}$.

Como comentado, os flashbacks associados à memória caracterizam os personagens e são decisivos no desenvolvimento da trama de Inversão. Eles atormentam e conduzem o desolamento de Juliana e, de modo extremo, a morte de Marcão. É com Marcão que temos o primeiro flashback, quando o revemos cumprimentar Ari; a ação foi vista há cerca de três minutos e reaparece instantes antes dele matar o amigo. O cumprimento e a imagem do disparo contra Ari reaparecerão como flashbacks outras três vezes durante a permanência de Marcão na mata. Se, como nos outros casos, a reiteração não agrega nenhuma nova informação (sabemos que eles eram amigos e que Marcão o matou), as repetições do cumprimento e do disparo, associadas aos sons e planos da mata e do céu coberto pela vegetação que é assombrada por flashes, diferem do esvaziamento de sentido comentado acima, pois criam um quadro mental de angústia crescente que evolui para um estado patológico, beirando o delírio. Ter assassinado o amigo não é para Marcão uma memória qualquer, mas uma recordação que constrói e evidencia uma memória obsessiva, traumática, que foge do controle do personagem e que desestabiliza seu presente.

Se os flashbacks em si são um tanto "comportados" (isto é, apenas repetem em preto e branco trechos do passado), as recordações de Marcão surgem junto de indicações de delírio e alucinações: o personagem ouve ruídos, atira contra a mata e com o flashback revemos ele atirar no amigo. Os flashbacks de Marcão aparecem retomando um passado que o assombra, representando sua obsessão com a ação cometida e uma voz que é interna

12 Ibid., p. 68. 
e não externa ${ }^{13}$. O tormento chegará ao limite, levando-o à morte. Fitando o mar, Marcão tem seu último flashback de quando colocara o corpo do amigo no porta-malas. Após pular no oceano o personagem é visto apenas em uma sequência futura, morto, do outro lado da travessia. Como assombração, a memória traumática o desestabilizou e o levou ao seu fim. Com esse personagem, a reiteração do passado com a repetição do flashback não esgota a linguagem, pois é através da reapresentação da mesma ação que se constrói o quadro perturbado do personagem, expressando seu estado psicológico e justificando sua ação final - o suicídio.

Como os flashbacks de Marcão, as imagens que compõem as agressões privilegiam um estado subjetivo dos personagens em detrimento de um êxtase produzido pela ação fervilhante, como no formato do filme de ação discutido em Salve Geral. Assim, vemos o disparo de Luís contra o piloto e do personagem contra David, todavia, o tiro é rápido, exibido através de um plano estável. Mais longa que a ação, os sons e as imagens de tormentos (raios no céu e sons perturbados) enfatizam um estado interno em detrimento de destacar a ação em si. No extremo de não ressaltar a imagem literal da agressão o assassinato de Mila é construído com uma tela preta e som de tiro. A única cena de agressão que é exibida com destaque é a de Juliana contra o estuprador, que assumiria o sequestro. A construção beira o grotesco, vômito, pau-de-arara, corpo nu do estuprador e o close em sua testa que é rasgada pela delegada. A cena expressa a submersão de Juliana no universo da dupla policial, mas ela vai mais fundo que eles, pois não se limita ao modus operandi da dupla que é violenta com suspeitos para arrancar informações. Juliana ultrapassa o "limite profissional" e afundará em sua angústia.

Desse modo, tanto na evidência da agressão de Juliana quanto na discrição da ação (assassinatos vistos ao longo do filme), o que se privilegia é o perturbado estado

\footnotetext{
${ }^{13}$ Como o hauting of the past que, segundo Turim, representa certa obsessão do personagem com o passado, obsessão esta que às vezes é patológica. Com a subjetividade focalizada, temos pensamentos no lugar de uma história narrada e, assim, a voz é interna em vez de externa. Ibid., p.33.
} 
interno dos personagens. O caso mais expoente surge com o primeiro assassinato dos seguranças em que a montagem é de uma construção ímpar, que se distancia intensamente da representação das aparências exteriores que compõe a tendência geral na lógica da transparência de diversos realismos ${ }^{14}$. Sem ter sua força na figuração da ação, as cenas de agressão são potentes para criar a tensão e apreensão das situações e, ao lado de outros elementos, construir a atmosfera turva do filme.

Como nos espaços que serão comentados a seguir, os rostos marcados pelas sombras e as cenas que privilegiam os tormentos remetem ao expressionismo não necessariamente pela aparência, mas, principalmente, pela operação de traduzir simbolicamente, através de linhas, formas e volumes - e aqui através da montagem - a mentalidade dos personagens e seu estado de ânimo, em uma construção plástica de seus dramas ${ }^{15}$.

Com esse quadro heterodoxo, voltamos à reflexão do início: o que o filme expressa com sua miscelânea? Mas antes, faz sentido pensar Inversão na chave do cinema experimental? Como pensar a mistura das construções que remetem às práticas das vanguardas com clichês e iconografias de gêneros que aparecem aqui sem a ironia ou o sentido de desconstrução vistos em filmes como Pierrot le fou (Godard, 1965) e O Bandido da Luz Vermelha (Rogério Sganzerla, 1968)? Essa ambiguidade entre linguagem que experimenta novas formas e elementos mais tradicionais (aqui clichês e bordões que repetem fórmulas) remete ao antigo conterrâneo São Paulo, a sinfonia da metrópole (Kemeny \& Lustig, 1929). Com fotografia sofisticada junto do estilo institucional, a sinfonia paulistana poderia marcar o início do experimentalismo cinematográfico do país ${ }^{16}$. Mesmo estando sintonizado com o moderno quadro das vanguardas artísticas que compõem as sinfonias das cidades, o filme

\footnotetext{
${ }^{14}$ XAVIER, Ismail. O discurso cinematográfico: a opacidade e a transparência. São Paulo: Paz e Terra, 2005.

${ }^{15}$ MITRY, Jean. Futurismo, expressionismo y cine. In: Historia del cine experimental. Valencia: Fernando Torres, 1974.

16 MACHADO, Jr., Rubens L. R. O Pátio e o cinema experimental no Brasil: apontamentos para uma história. Teresina: EDUFPI, 2009, p. 9.
} 
de Kemeny e Lustig abandona a reflexão sobre as consequências trágicas da modernidade e é marcado pelo intenso elogio à incipiente modernidade paulistana, configurando assim, um filme "moderno e parnasiano"17.

Do mesmo modo, apesar de não se alinhar às práticas da vanguarda e de não questionar o estatuto da arte, estilisticamente Inversão pode ser pensado na chave do experimental um experimento que, ao associar clichês e efeitos que se repetem e se esvaziam, se torna bastante singular. Inversão parece acreditar nessa miscelânea de estilos e referências na construção da trama policial que mantém também lugares-comuns para além dos gêneros cinematográficos (mulher frágil que sofre no ambiente masculino, cidade sempre cheia etc.), mas que, pelos exageros - talvez não intencionais - desenvolve um curioso comentário acerca dos personagens na cidade.

\section{Cidade-Selva}

A cidade é construída com alguns bordões afirmados nos offs de Carlão ("trânsito 'foda', paranoia total", "quando a gente precisa de [um] suspeito vai à periferia") e também através de imagens. As vias congestionadas por onde circulam grandes volumes de carros e as calçadas repletas de transeuntes remetem a uma imagem de São Paulo extremamente povoada, que, apesar de nunca parar, é sempre difícil de ser percorrida. Entre os espaços que constroem a cidade de Inversão há locais característicos, como a Avenida 23 de Maio, Avenida 9 de Julho, a Rua Vergueiro, o Obelisco do Ibirapuera, a Avenida Paulista e o Parque Trianon. Há também os cenários periféricos, comentados no início, que são marcados por emaranhados de fios e por certa espontaneidade dos passantes. A cidade é amarelada, um amarelo que remete à fotografia envelhecida, mas que também pode ser

17 Ibid. Idem. 

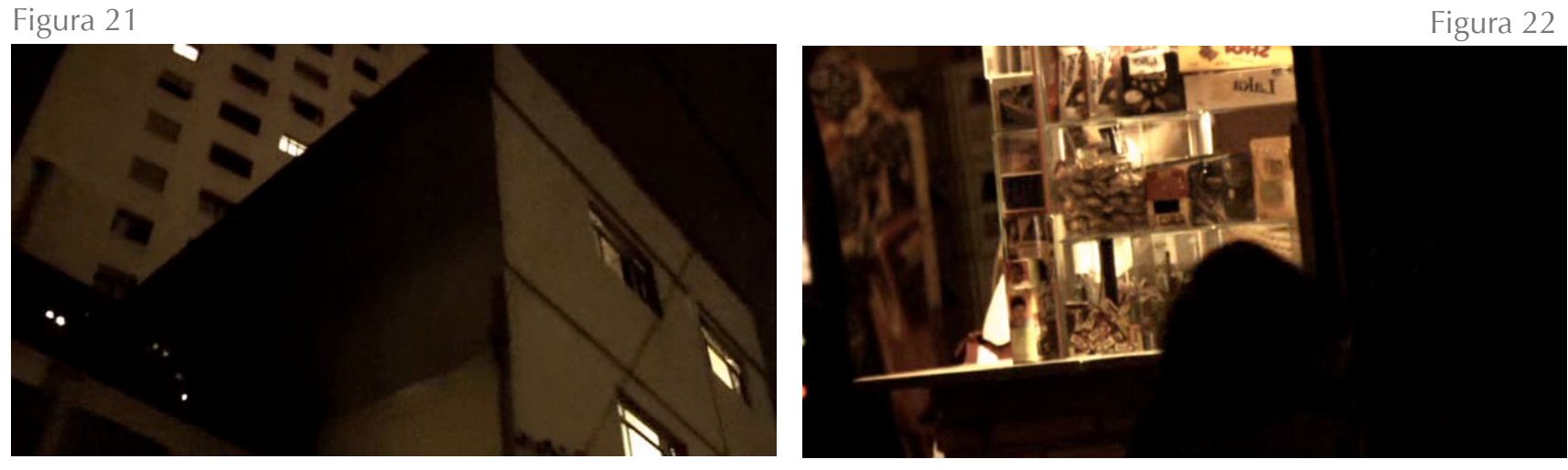

A cidade recortada e distorcida de Inversão (imagens 21 à 24).

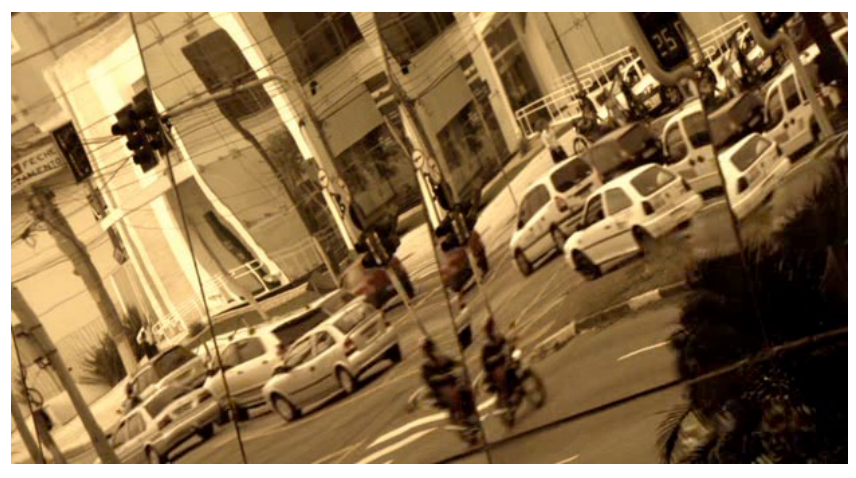

Figura 23

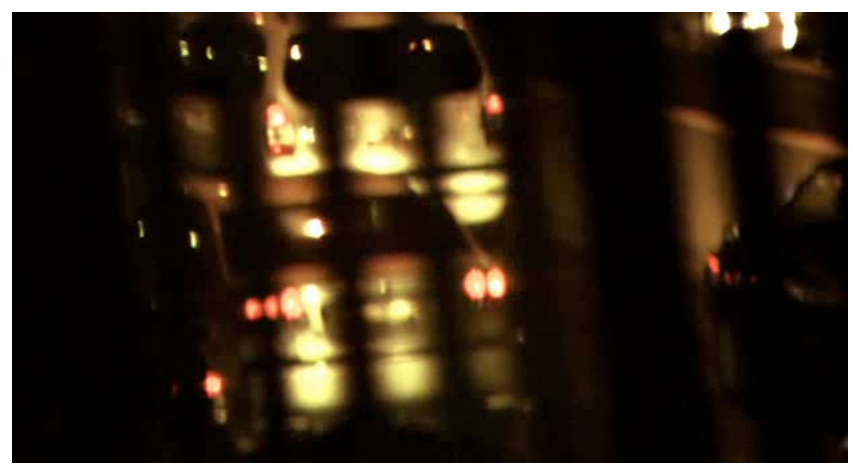

Figura 24

associada ao amarelo da doença, de um estado febril. Como os personagens - muitas vezes bastante recortados e enquadrados em ângulos oblíquos - os espaços da cidade também aparecem com formas distorcidas.

A cidade é áspera e parece ser acolhedora apenas para aqueles que têm astúcia, conhecem e jogam com a ilegalidade e sabem se mover nos inóspitos e sombrios ambientes, como Carlão, Ariovaldo e também Mendonça que, sobrevivendo à mata e aos sequestradores, retorna vitorioso à cidade. A distorção dos rostos dos personagens marcados pelas sombras ecoa na distorção dos espaços: como os personagens a cidade é "feia, suja e má". O ambiente urbano de Inversão remete à cidade do gênero policial: é “(...) uma espécie de extensão da violência e da brutalidade de seu mundo"18. Mas aqui a extensão da violência não se restringe ao concreto, chega à mata onde a hostilidade do

${ }^{18}$ McARTHUR, Colin. O filme policial. Lisboa: Horizonte 1990, p. 29. 
meio na luta do homem contra a natureza não se equipara à agressividade dos personagens que lutam entre si. Não se trata de edificar urbano versus mata, as oposições são diluídas pela analogia entre os espaços. Aqui, a mata equivale à cidade: ambos são locais ásperos, com contrastes intensos e formas distorcidas, ambientes hostis que abrigam sentimentos e ações semelhantes.
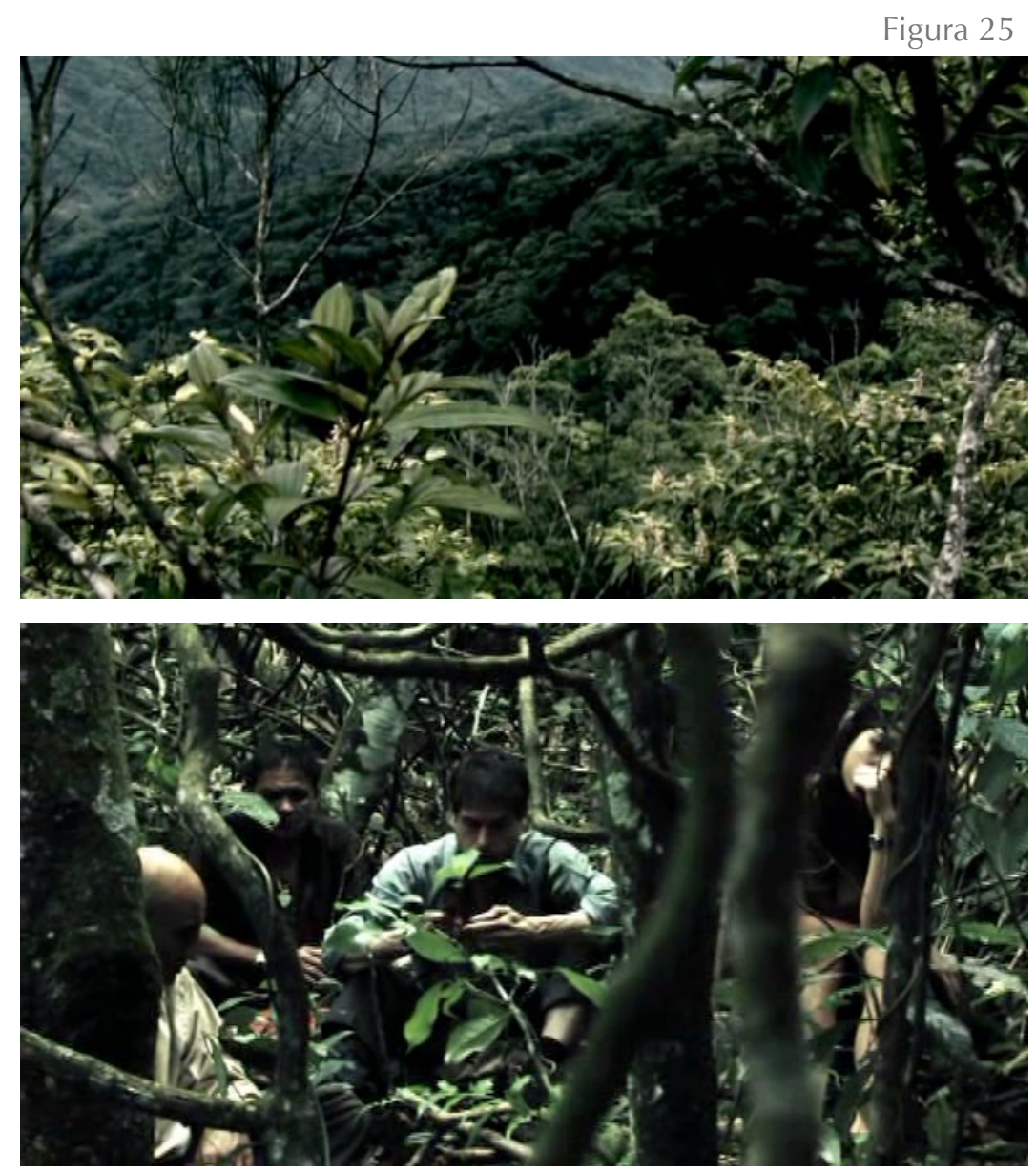

Galhos e troncos com contornos retorcidos. 0 contraste claro/escuro se mantém na fotografia esverdeada da mata (figuras 25 e 26).

Figura 26

O cenário da mata poderia sugerir alguma referência ao seriado Lost - que também é repleto de flashbacks que, diferentemente do que vemos em Inversão, são exteriores ao tempo inicial da trama e nos trazem o passado dos personagens. Mas a proximidade entre o longa aqui analisado e a série se encerra na coincidência da paisagem natural onde os personagens se veem presos. Na trama de Lost há espaços para solidariedade, romances e outras histórias que não apenas conflitos. Em Inversão, a permanência da mata 
é permeada apenas pela aspereza das relações e do cenário (além dos galhos retorcidos, quando finalmente encontram o mar, os personagens se deparam com uma praia que, no lugar da característica areia das praias brasileiras, é coberta de pedras sobre as quais tudo se precipita).

Após a realização do sequestro, para além do elemento divino ("trabalhos" de Darcy), as ações paralelas entre cidade e mata não interferem uma na outra. Se essa estrutura narrativa não aponta para uma teia de causa-efeito, ela parece tecer metáforas e construir semelhanças entre os dois grupos de personagens. Vemos se alternarem sequências em que os policiais são violentos com suspeitos; sequestradores agem de modo violento tanto com Mendonça quanto entre si, em que Juliana está angustiada e pressionada para resolver o caso; Marcão está desolado à beira da loucura por ter assassinado o amigo; Ariovaldo é autoritário, Mila também; Juliana busca se adaptar à nova função, os sequestradores ao novo ambiente. Tanto policiais quanto sequestradores circulam por espaços que se repetem em trajetos onde há pouca esperança de saída.

Sem uma teia de causa-efeito, o paralelismo constrói e reforça equivalências: dos dois lados há desesperança entre personagens violentos, correndo contra o tempo para sobreviver. Cidade e mata, certo e errado, bom e mal, a despeito do antagonismo dos termos, a narrativa de Inversão tece equivalências entre os personagens que, se à primeira vista estariam em lados opostos, se aproximam pelas ações que enfrentam e parecem moralmente lado a lado. No fim do filme, os grupos não apenas se encontram, mas se penetram: Carlão e Ariovaldo passam a ser seguranças de Mendonça e abandonam o grupo "policial", deixando Juliana, que não participa do jogo e termina sozinha e desolada.

Não sabemos sobre o passado nem sobre o presente dos personagens cuja individualidade é pouco explorada, inclusive na direção de arte (por exemplo, as poucas casas em que penetramos, de Juliana e Mendonça, contêm apenas objetos essenciais). Para além do rendimento econômico - da propina arrecadada pelos policias e do montante 
que seria exigido como resgate de Mendonça - não conhecemos a motivação de nenhum dos personagens que, quando surge com o flashback-transe de David, é pouco inteligível. Despossuídos de individualidade, os personagens são como o arquétipo da elite empresarial e da polícia.

De ambos os lados o esquema racional de ação-reação é frágil: os personagens agem como que guiados por um instinto agressivo que, sem demais caracterizações, não promove nossa identificação com nenhum deles. O desenvolvimento do filme ocorre em torno de uma andança febril das figuras que flertam com a loucura e, nos casos em que não se integram ao jogo, serão consumidos pela desilusão (Juliana) ou pelo delírio (Marcão).

A cidade-selva de Inversão remete ao "mundo originário" da imagem-pulsão. O mundo originário não é como o espaço-qualquer, desconectado dos meios determinados, mas possui intensas relações com o meio histórico e geográfico que lhe serve de veículo e de inspiração. A partir dos comportamentos que se desenrolam nesse meio histórico, o mundo originário extrai suas pulsões:

Dir-se-ia que o mundo originário só aparece quando se sobrecarrega, adensa e prolonga as linhas invisíveis que recortam o real, que desarticulam os comportamentos e os objetos. As ações se superam rumo a atos primordiais que não as compunham, os objetos rumo a pedaços que não os reconstituirão, as pessoas rumo à energia que não as "organizam". A um só tempo: o mundo originário só existe e opera no fundo de um meio real, e só vale por sua imanência a este meio, cuja violência e crueldade revela (...) (DELEUZE, 1985, p. 159).

De modo semelhante, os traços da cidade e dos personagens parecem preservar e adensar a aridez do meio que também dá forma às relações. Na cidade-mata os personagens são levados a participar do jogo da ilegalidade e da traição. Ainda na proximidade com a 
imagem-pulsão, o modo agressivo dos personagens remete também aos "bichos humanos" que integram o naturalismo, como Deleuze caracteriza esse estilo.

O urbano não oferece outra saída que não seja a loucura aos que estão fora do esquema, aos que não sabem se locomover em meio às suas sombras. Como as lembranças que, majoritariamente, se encerram nos cinco dias da trama, a narrativa também desenha seu círculo que aprisiona o fluxo dos personagens, pois apenas a morte extravasa as possibilidades entre as trajetórias policial e empresarial delimitadas no início.

\section{Sombras, fantasias e "realidade"}

Apesar do reiterado apelo ao real - ressaltado pelo rap, pelas cartelas ("baseado em fatos reais" e "maio de 2006 - São Paulo estava sendo atacada (...)") e pelos offs de Carlão, Inversão se afasta do evento que nos apresenta no início (os ataques do PCC) e também das convenções que marcam o realismo. Diferente de Salve Geral que tem os ataques como substrato da trama, em Inversão é curiosa a forma enfática com que os ataques surgem no início para voltar apenas junto aos créditos finais através de outra cartela ("os ataques à cidade de São Paulo terminaram... por enquanto"). No filme a menção aos ataques será importante na construção de seu clima literalmente noir, mas a referência também é cara à reiteração da "realidade" na qual a narrativa se move, realidade essa que, para espanto do narrador, não vem da periferia.

No paralelo entre Invasor e Inversão comentado no início deste capítulo, o rap, que surgirá também em Inquilinos, é um elemento que aponta a singularidade dos títulos. Em Invasor o rap surge em especial com o rapper Sabotage, "personagem real", que viveu em favelas como a do Canão e do Boqueirão e que foi vítima da violência urbana (dois anos após o lançamento do filme, Sabotage foi assassinado). A inserção do rap e do músico em 
Invasor foi elogiada pela crítica por trazer uma "carga documental" à ficção - comentário que, no geral, ignora o aspecto poético da música. Em Inversão, o rap - que também é acompanhado do rapper Túlio Dek - soa um tanto deslocado do estilo.

O tom brando da composição de Túlio Dek, músico com trajetória bastante distinta da dos rappers do país (Túlio conheceu o rap quando morava em Los Angeles), se distancia daquilo que predomina nos raps nacionais. No país, via de regra, o gênero representa o testemunho daqueles que estão no "olho do furacão", no centro das mais contundentes problemáticas urbanas ${ }^{19}$. Com a rejeição ao estrelismo perpetuada pelos rappers brasileiros, cada jovem pobre se vê como um potencial rapper "(...) capaz de contar sua vida no ritmo repetitivo e opressivo, nas rimas obrigatórias, às vezes preciosas, às vezes brutais, executando a dança que não autoriza alegria nenhuma, sensualidade nenhuma" ${ }^{20}$. Em São Paulo, o hip hop está entre os movimentos de periferia que são articulados como resposta à segregação e à violência que atinge, de modo mais contundente, os jovens dessas regiões. Caracteristicamente os "manos" falam sobre a periferia, para a periferia, na periferia, local onde criam uma das mais potentes críticas à desigualdade social, à injustiça e ao racismo já articuladas no país ${ }^{21}$.

De modo diverso, em Inversão o rap faz coro à voz do diretor, à sua crítica à classe média, que, como vimos, se dirige à elite. Assim a música se distancia da tradição do rap nacional que aborda o "real [que] domina a periferia, em suas faces extremas", isto é, com a droga, a morte e a violência como destino inexoráve ${ }^{22}$. Como certo deslocamento (ou "inversão") dessa tradição se produz um dos ruídos do filme: contrariando as características

\footnotetext{
${ }^{19}$ MARICATO, Ermínia. As testemunhas da cidade oculta: Racionais MC. In: Metrópole na periferia do capitalismo - ilegalidade, desigualdade e violência. São Paulo: Hucitec, 1996, p. 107. ${ }^{20}$ KEHL, Maria Rita. Radicais, Raciais, Racionais: a grande fratria do rap na periferia de São Paulo. São Paulo em Perspectiva [online], 1999, p. 95.

${ }^{21}$ CALDEIRA, Teresa Pires do Rio. Hip-Hop, Periphery, and Spatial Segregation in São Paulo. Urban Traumas. The City and Disasters, Barcelona, 2004, p. 261.

22 KEHL, Maria Rita. Radicais, Raciais, Racionais: a grande fratria do rap na periferia de São Paulo. São Paulo em Perspectiva [online], 1999, p. 103.
} 
que marcam o estilo musical no Brasil, a "realidade" exaltada pelo rap (e também pelo filme) é ligada à elite. O rap, cuja letra surge junto da cartela que fala sobre os ataques e que retorna na "cena-videoclipe", expressa sua função narrativa tributária do "real" aclamado pelo longa. Como o filme, a música narra a inversão construída pela trama, isto é, contrariando o que o longa afirma como sendo o esperado, a prática do crime não vem dos mais pobres, mas da elite - classe que trai no interior da família e que leva a concorrência a consequências extremas:

Impressionante como tudo se inverte

Pode ser que eu erre, pode ser que eu acerte

Inverteram o meu mundo, "tá" tudo invertido

Não sei quem é amigo, não sei quem é bandido

Não sei se sou, ou se não sou culpado

Só sei que na minha mente, "tá" tudo embaralhado

A ganância me leva a perder os meus valores

Sinto esse fardo, ao vivo e a cores

Tá tudo tramado, tudo foi mandado

Me perco entre ratos e aliados

Com olhos cansados, corpo baqueado

Para sair a salvo nem que seja a nado

Como essa canção, outro rap também terá explicitada sua função narrativa. A composição "Loki" (de Diogo Poças e Elly Pretoriginal) surge junto com Waltinho (personagem interpretado por Tulio Dek); se o rap mencionado acima pode ser associada à Mendonça, a letra de "Loki" sugere as características do personagem-cantor que auxilia nos bastidores do sequestro: "tinha um perfil acima de qualquer suspeita, a cor da pele 
clara e um rosto para o crime (...) um laranja nesse time, otário malandrão, seu perfil para o crime". Diferente das trilhas originais de Salve Geral, as de Inversão não estão atreladas à tradição musical do cinema (dos soundtracks) e de modo mais explícito e textual (através da letra) expõem o papel narrativo da canção.

Semelhante ao que vemos em Invasor, Inversão aponta para uma contaminação entre personagens, trama e estado devastador da cidade. Nesse sentido São Paulo é uma locação ideal para esse tipo de narrativa: “(...) enquanto metrópole periférica [e] caótica, típica do capitalismo tardio, [São Paulo] constitui [um] terreno propício para a atualização do thriller policial e seus enredos recheados de chantagem, conspiração, ganância, assassinatos e um pessimismo generalizado"23. Em Inversão esse enredo contamina paisagem e personagens que surgem com aspectos disformes e doentios e, nessa operação, os elementos que experimentam no campo da linguagem têm importância fundamental.

Inversão constrói um quadro amplamente patológico que se estende dos personagens aos ambientes (e vice-versa) - a sinuosidade do urbano-selva se prolonga do cenário às relações que abriga. Os personagens parecem se mover e agir guiados como que por um estado doentio que remete ao sonambulismo das figuras do expressionismo. Se num primeiro instante a aclamação pelo real parece contrastar com os experimentos, com a imersão nas fantasias, sombras e alucinações, o paralelo com o expressionismo pode ajudar a equacionar melhor a questão.

A referência ao expressionismo não ocorre apenas pelas sombras e assombrações, mas, em especial, pela ação de traduzir plasticamente angústias e dramas e por realizar, a partir dos exageros, um comentário sobre o contexto que envolve o filme. Essa operação acontece em Inversão, em especial através do enquadramento, iluminação e também da montagem, elementos que expressam tormentos subjetivos e uma cidade doentia.

\footnotetext{
${ }^{23}$ NAGIB, Lúcia A utopia no cinema brasileiro: matrizes, nostalgia, distopias. São Paulo: Cosac Naify, 2006, p. 166.
} 
Diferente dos cenários construídos no início do expressionismo (como em O gabinete do Doutor Caligari, Robert Wiene, 1920), aqui são os espaços da cidade que oferecem à câmera o tecido que será distorcido. Espelhando a cidade e seus personagens, a mata aparece também retorcida nas formas de galhos e folhas, ambiente perturbado pelos ruídos que repõem a aspereza do urbano.

Além da semelhança nessa operação plástica, o exagero na caracterização dos personagens (apenas maus e violentos) e da cidade (sem alívio para a sua aridez) remete também às deformações do expressionismo ${ }^{24}$. Tanto sequestradores quanto policiais aparecem com poucas nuances. Construídos de modo um tanto caricato através do sadismo e das ações ilícitas, violentas e abusivas, os policiais e os sequestradores adquirem contornos grotescos e desproporcionais, o que se intensifica por não terem sua individualidade, passado e motivações desenvolvidas. Esse traço exagerado no cenário oblíquo e áspero e nas personalidades agressivas remete às deformações expressionistas que não buscavam construir fantasmagorias formais, mas revelar "as atitudes definitivas"25. Do mesmo modo, como no comentário sobre a paisagem que remete ao mundo originário, Inversão mantém apenas os traços mais agudos da cidade e dos personagens que são exagerados. Esses traços surgem aqui como as essências de São Paulo e da elite definidas pelo filme.

Associado aos experimentos da linguagem e da relativamente incomum história, Inversão ilustra a gama de tramas que os ataques de maio de 2006 puderam inspirar. No próximo capítulo, em Inquilinos, os ataques também receberão um destaque menos direto em construção bastante instigante e crítica sobre a própria constituição fílmica. Os ataques aparecem como parte de um cotidiano da periferia que é afetado e invadido pelo crime e pela violência urbana - que, como em Inversão, não surge com a espetacularidade de Salve Geral.

\footnotetext{
${ }^{24}$ MITRY, Jean. Futurismo, expressionismo y cine. Valencia: Fernando Torres, 1974.

${ }^{25}$ Idem.
} 


\section{Capítulo 3}

\section{Os Inquilinos - os incomodados que se mudem}

Dirigido por Sérgio Bianchi e realizado no mesmo ano de Salve Geral (2009), Os Inquilinos - os incomodados que se mudem traz uma abordagem quase que inversa dos dois títulos anteriores: sem se centrar em policiais, criminosos ou detentos, Inquilinos se foca na família afetada em seu cotidiano pela chegada dos novos vizinhos, que parecem romper com a harmonia familiar ao trazer para a casa ao lado as ameaças anunciadas pela TV e pelas fofocas. Como em Inversão, os ataques (do PCC) não surgem aqui em primeiro plano, mas sim como parte da paisagem da São Paulo construída pelo filme. Em Inquilinos a violência, cuja prática não será sequer sugerida pela montagem ou pelo grafismo, aparece ralentada nas diversas frestas do dia a dia como um espectro com contorno às vezes mais, às vezes menos, concreto. Escrito por Beatriz Bracher e Bianchi, o roteiro foi inspirado em um conto de Vagner Ferrer - aluno do programa Educação para Jovens e Adultos. No elenco, atores com trajetória na TV e no cinema, como Cássia Kiss, Ana Carbatti e Marat Descartes - ator que ficará marcado pelo estilo de personagem inerte que parece inaugurar aqui.

Na comparação com os outros dois filmes e também com relação a diversos títulos da vertente recente que aborda a violência vivida nas metrópoles do país, Inquilinos apresenta um tratamento ímpar e instigante da problemática. No lugar de imagens literais que exibem a ação violenta, as narrativas sobre a violência (que no filme são formadas pelos sons da TV, diálogos, fofocas e especulações dos personagens) surgem com uma posição central sob a forma de espectro, isto é, como uma massa que segue os personagens nas mais distintas situações. 
Sem estrutura de agressão ou provocações contundentes temperadas com cinismo, Inquilinos parece destoar da filmografia de Bianchi que, caracteristicamente tem poupado a poucos, lançando críticas e provações diretas contra as mais diversas classes sociais, contra o espectador e até mesmo contra si, realizador que filma "despossuídos". Como veremos, mesmo sem a agressividade e o tom do cinema de confronto que caracterizam a filmografia do diretor ${ }^{1}$, Inquilinos é marcado pela ironia, provocação e ambiguidade, que em outra tonalidade imperam no filme e continuam a ecoar no desencanto e na impotência diante do inexorável.

Com uma linguagem mais poética e sutil, Inquilinos se estrutura em torno do cotidiano de Valter entre trabalho, escola e o ambiente familiar ao lado da esposa Iara e dos filhos Fernanda e Diogo. Em sua forma e conteúdo, Inquilinos se distancia tanto da linguagem mais frenética dos expoentes Cidade de Deus e Tropa de Elite (e também das sequências de ação vistas em Salve Geral) quanto das produções paulistanas nas quais a violência cobre de modo áspero toda a superfície diegética, como em Um Céu de Estrelas, Contra Todos e Invasor - filmes nos quais as agressões e ameaças entre os personagens se estendem por todos os lados.

Longe do esquema da narrativa clássica de Salve Geral, Inquilinos não se estrutura em torno de uma meta perseguida pelo personagem. O longa dirigido por Bianchi também se distancia da andança febril vista em Inversão. O extremamente interligado binômio cotidiano/espectro da violência em que pendulam medo e a curiosidade fomenta o mistério e move a trama do filme. Sem grandes acontecimentos, buscas ou ações, o que impera na narrativa de Inquilinos é um ritmo vagaroso do cotidiano, permeado pelo clima de suspense que se insinua através de ruídos, rumores e olhares para o outro lado do muro, construindo e desconstruindo expectativas que são filtradas pelo peculiar olhar de Valter - personagem-

\footnotetext{
${ }^{1}$ VIEIRA, João Luiz. O cinema provocação de Sérgio Bianchi. Programadora Brasil, Rio de Janeiro, nº 2, 2008.
} 
espectador - que vai se tornando cada vez mais acuado.

A janela (do latim januella, diminutivo da palavra janua [porta]), desfaz a parede, interrompe o fechamento do espaço privado $^{2}$ e conecta Iara/Valter aos inquilinos por meio dos olhares que lançam ao lado. Como veremos, a janela é um elemento importante na configuração espacial, da mise-en-scène e também na construção do suspense que se insinua. A força da janela articula ainda uma crítica (que não deixa de ser autorreferida) acerca do espetáculo.

Apesar da aparência mais amena e das ações corriqueiras que predominam na trama, é justamente sobre a superfície do cotidiano que o filme retoma o tom distópico da filmografia de Bianchi. Por meio das trilhas, imagens, diálogos e da montagem, Inquilinos desenvolve comentários irônicos e ácidas críticas, em especial, acerca da sociabilidade em uma cidade onde paira o espectro da violência, isto é, essa massa composta por ações vistas, contadas, imaginadas ou reportadas que, como uma nuvem, cobre as diversas situações do dia a dia.

\section{Uma narrativa do cotidiano}

Ao som dos repetidos primeiros acordes de Un Grand Sommeil Noir (composição de Ravel para poema de Verlaine) o filme se inicia com um quadro coberto de cima a baixo por casas de alvenaria. Sem reboco, o tom alaranjado das casas contrasta com o verde da solitária árvore que resiste no centro da imagem; ela se torna ainda mais só quando, através de uma fusão, o quadro se abre e as casas se multiplicam na tela (figura 1). Apesar da abertura do plano, continuamos literalmente sem perspectiva: a imagem é chapada, não há chão nem céu. Fundindo-se sobre esse "muro de casas", o horizonte surge apenas no

\footnotetext{
2 JORGE, Luís Antônio. O desenho da janela. São Paulo: Annablume, 1995, p. 21.
} 
quadro seguinte, sobre o topo do morro, onde as feições

e cores das habitações

são mais diversificadas.

Passamos então para a

rua onde algumas crianças

brincam e, com a grave

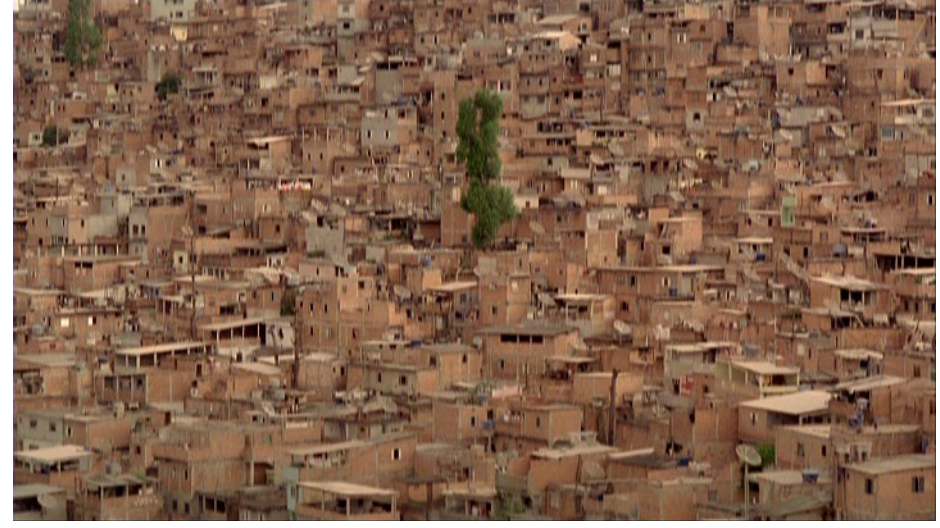

Figura 1

Muro de casas que abre o filme.

trilha de suspense que se

inicia, as (literalmente) sombrias formas adquirem um tom soturno. Com um travelling, nos aproximamos da casa onde, saberemos depois, reside a família de Valter. Do lado de fora, somos atraídos para o lar pela discussão que parece recrudescer lá dentro. Todavia, a tensão e o suspense se dissolvem quando, dentro da casa, vemos Fernanda em frente à TV assistindo à cena que se desenrola na novela. Logo ao lado, na cozinha, Iara conta para Valter o caso da vizinha que apanhou do marido.

A contragosto Fernanda sairá da frente do televisor para jantar com os pais e com o irmão. Indagada sobre o livro que leu para a escola, ela conta: "é a história de uns homens maus, que chegam a uma cidadezinha calma e bagunçam tudo. No final eles morrem e todo mundo fica feliz". A história do livro, que sintetiza de modo genérico diversas narrativas, dos westerns aos filmes policiais, também remete e anuncia a estrutura de Inquilinos (que, todavia, terá um desfecho diferente). Resumido assim, sem referência de tempo ou espaço, a história do livro introduz a problemática do filme com um tom universal, ao mesmo tempo em que banaliza e cria uma tensão com a referência à São Paulo de 2006 que o filme faz.

O jantar logo será interrompido pelos sons de buzinas e berros, primeira expressão dos novos vizinhos, isto é, dos inquilinos que acabaram de chegar. Eles atraem a curiosidade de todos: primeiro das crianças que, rapidamente, correm para a janela da sala (figura 38) e 
sobre o sofá espiam a rua da frente. A seguir Valter vai até o portão e então Iara introduz a privilegiada vista da vidraça da cozinha de onde espia o novo vizinho que, sem camisa, se exibe no quintal ao lado (figuras 35 e 36). A conversa entre Iara e Valter sobre os vizinhos é interrompida pelos estrondos e gritos que vêm do lado de lá e que reforçam a desconfiança preliminar do casal. Ao som de Assistir a sequência uma reportagem sobre ataques a ônibus, Valter tranca a porta e cerra as janelas. Senta-se então ao lado de Iara, em frente à TV, para assistir à escabrosa matéria de (José Luiz) Datena sobre uma criança violentada e morta. Essa matéria marca os personagens e será melhor discutida mais à frente.

De modo interessante esses primeiros minutos anunciam importantes questões da narrativa, em especial, a centralidade das janelas e a importância do espaço onde vivem os personagens que, sob a aparente harmonia, contém uma tensão latente. A sequência anuncia também a forma como a (virtual) violência que circunda a trama será construída durante todo o filme. No lugar da imagem literal da agressão, Inquilinos constrói um espectro formado por falas, boatos, notícias e imaginários dispersos no cotidiano que fascina e convida os personagens a conjecturar, bisbilhotar e narrar casos uns aos outros. Como nessa primeira sequência, o encadeamento entre ações, imaginários, insinuações e discursos (dos diálogos e sons da TV) continuará em toda a narrativa.

Com um ritmo suave, o filme se estrutura em torno da rotina de Valter entre casa (em um bairro periférico genérico ${ }^{3}$ ), trabalho (Ceasa, Zona Oeste) e escola (Valo Velho, Zona Sul) onde ele termina os estudos. Sem uma meta perseguida pelo personagem, a narrativa se passa nesse constante trânsito entre a mesa de café da manhã ao lado de Iara e dos filhos, a caminhada até o ponto do ônibus com o vizinho Francisco, o turno de trabalho no Ceasa, a caminhada do ônibus até a escola (figuras 6 a 8), a sala de aula e,

\footnotetext{
${ }^{3}$ Como comentarei a seguir, apesar de muitas proximidades com algumas características da Brasilândia (bairro da Zona Norte paulistana onde boa parte do longa foi rodado) a narrativa constrói um bairro periférico genérico, pois não nos oferece nenhuma informação sobre sua localidade.
} 
novamente, a rua do bairro e a mesa de casa onde janta (como na série de figuras na página 119). Apesar do intenso e diário deslocamento entre zonas extremas da cidade, os trajetos serão na maior parte das vezes omitidos. Além das elipses, o Ceasa e a escola aparecem apenas durante os turnos de trabalho e aula, reforçando assim a centralidade do bairro na narrativa - cenário único dos finais de semana. Nas folgas, Valter permanece no bairro que é exclusivamente composto pela rua de frente de sua casa e pela rua de cima onde Francisco mora (os espaços do bairro estão esquematizados no Anexo I). Nessas duas ruas, Diogo e Fernanda brincam, Valter lava o carro e ajuda a transportar o armário do amigo. Na rua de frente surgirão também fagulhas com os inquilinos. Aos finais de semana, além da sala e da cozinha que marcam a rotina dos dias úteis, o quintal dos fundos da casa da família de Valter aparece também como lugar de permanência e de conversas.

Nesse dia a dia as suspeitas sobre quem são os novos vizinhos vão crescendo. A chegada dos inquilinos que passam a morar na casa do fundo do quintal de Seu Dimas (antigo morador com quem, há muito, a família de Valter divide o muro), atualiza e se mistura com os perigos narrados pela TV, pelos diálogos e pelas constantes fofocas, alimentando um quadro repleto de suposições. A "estranha" rotina dos jovens que não saem para trabalhar, e fazem ruídos tardios e festas barulhentas que despertam o casal, nutre a crescente curiosidade e a atenta imaginação dos personagens.

O desejo de saber sobre os jovens e misteriosos vizinhos é compartilhado por todos, mas vivido em especial por Valter e, principalmente, por Iara que atualiza os boatos sobre a violência, a vizinhança e também sobre os inquilinos. Iara pressiona Valter à ação e instiga sua suspeita sobre um hipotético caso com os jovens ao lado. Com investidas mais enérgicas, Iara constantemente fala e reclama dos novos moradores e esboça grande deleite nas miradas lançadas através da janela para o outro lado do muro, olhar que, por vezes, será também simpaticamente devolvido por um dos inquilinos (eles não têm nome). Com suas falas, olhares e insinuações que provocam a imaginação do marido e a seguir com 
reclamações que o impelem à ação, Iara parece protagonizar mais que Valter - personagem que mais assiste do que age sobre aquilo que se passa à sua volta.

Apesar de o pequeno muro separar os terrenos, a fronteira entre os espaços (o da família e o dos inquilinos) é fortemente construída através da janela. Ao mesmo tempo em que constitui a fronteira que separa os dois ambientes, a janela também os coloca em contato. $\mathrm{O}$ papel das janelas e a relação que os personagens têm com elas remete à "janela para o mundo" - expressão que dá conta do anseio renascentista com a invenção da perspectiva linear e que reverbera no cinema e na televisão, metáfora que aqui é literal: é de fato a janela da casa que lhes dá acesso a esse "outro mundo". Como uma fresta no muro, a janela permite que o olhar atravesse a fronteira entre as duas casas, alcançando o outro lado do muro, atingindo a outra cena, isto é, a dos inquilinos, que interessa à família e a nós espectadores. Como em Janela Indiscreta (Hitchcock, 1954) - e como em uma infinidade de filmes, é a hipótese do crime que adensa a atração exercida pelo outro lado. Como magistralmente explorou Hitchcock (principalmente em Janela Indiscreta e também em Vertigo [Um corpo que cai] - 1958), a exterioridade do olhar permite a maquinação do prazer voyeurista e a construção do fascínio pela imagem que se exibe - esquema nuclear do dispositivo olhar/cena do cinema ${ }^{4}$. Em Inquilinos, além de estruturar o espaço fílmico e boa parte da relação entre Iara/Valter e os inquilinos, a janela é um elemento importante na crítica que o filme irá construir acerca das espetacularidades que discutirei mais à frente.

Além dos olhares lançados através da janela, o casal consuma sua curiosidade com os diários diálogos e também através da imaginação, onde Valter conjectura hipóteses e se expressam com mais nitidez os temores e os desejos do personagem. Entre o medo da traição da esposa e a ameaça dos inquilinos, Valter colocará em prática seu desejo de reação apenas em sua imaginação.

\footnotetext{
${ }^{4}$ Em narrativas clássicas a dialética entre aparente absorção (da cena) e real exibição surge junto da lição moral e contenções puritanas. XAVIER, Ismail. O olhar e a cena: melodrama, Hollywood, Cinema Novo, Nelson Rodrigues. São Paulo: Cosac Naify, 2003, p. 19.
} 
Diferente do que vemos em Salve Geral e também das experimentações de Inversão, a violência em Inquilinos se manifesta de um modo que não passa pela grafia e que é construída de forma menos material ou "palpável". Embora seja um elemento central da narrativa, que está presente na maior parte das sequências e que adquire contornos sufocantes, a violência não se expressa no filme através de imagens ou da linguagem fílmica. Sem aparecer como imagem-violência ${ }^{5}$, mas como um espectro formado pelo desenho de Diogo, brincadeira das crianças na rua, pelas notícias, boatos e pela ficção dentro da ficção (novela e livro resumido por Fernanda), a violência surge com potência, se instaurando nas entranhas do cotidiano e, algumas vezes, irrompendo como "extraordinário" na rotina dos personagens.

Como uma sombra, o espectro da violência composto pelas ameaças, conversas, notícias e imaginação, segue Valter nas mais distintas situações e em todos os ambientes por onde circula. Em casa, o espectro surge com os barulhos noturnos dos inquilinos, pela novela, pelo livro resumido por Fernanda, com o desenho que Diogo faz para a escola, nas prazerosas falas de Iara, pela TV, na imaginação de Valter e também pela potencial ameaça dos inquilinos que se insinua do outro lado. Longe de ser um reduto que se opõe aos perigos da rua, o espaço privado é o microcosmo onde ocorre a intersecção das ameaças de fora que, sem se consumarem em ação, penetram, simbólica e potencialmente, o lar pelo áudio da TV, ruídos dos vizinhos e falas que, constantemente, evocam e atualizam suposições e casos violentos. A não reação de Valter e a ausência da imagem-violência e da estrutura de ação-reação sugerem a proximidade do filme com a imagem-tempo deleuzeana que será abordada a seguir.

Fora de casa, o atrito surge no bairro como um contingente que, desde a primeira sequência, já é esperado. Nas poucas cenas de trânsito (são apenas quatro no intenso

\footnotetext{
${ }^{5}$ HIKIJI, Rose. Imagem-Violência: mímesis e reflexividade em alguns filmes recentes. 1998. Dissertação (Mestrado em Antropologia) - PPGAS-FFLCH. Universidade de São Paulo, São Paulo, 1999.
} 
deslocamento diário) o espectro da violência e o clima de ameaça também estão presentes. No trajeto de Valter, os cenários dos ataques do PCC aparecem com bastante lirismo em dois momentos em que, junto da banda sonora extradiegética, expressam e endossam o sentimento do personagem e constroem a atmosfera da sequência. Os coletivos tomados pelas chamas e a blitz policial surgem ao som de "A morte do leiteiro" (Drummond) que, declamado com doçura pela professora, confere às imagens um tom brando, conectando os ataques à melancolia do texto que antecipa o que saberemos na cena seguinte: como o leiteiro, Evandro também não se redimiu da noite e foi morto. No trecho final do filme, ao som do majestoso Piano Quintet de Schnittke ${ }^{6}$, o fogo que queima o ônibus já não é tão intenso: os pequenos focos de chama que ardem no coletivo já bastante detonado e as batidas policiais constroem um cenário avassalado por onde o personagem se move. $\mathrm{O}$ ritmo lento do ônibus onde Valter atravessa o cenário destruído alonga o trajeto e faz coro à tristeza do personagem com a tragédia que se confirma.

Além dos ataques, os percursos de Valter são assombrados por pesadelos. Primeiro sonha que Iara flerta com um dos inquilino e, ao fim, com o cão que pula para o outro lado do muro e retorna com um braço decepado. Assim como as demais imaginações de Valter, ambos os pesadelos são construídos com imagens fundidas, com velocidade reduzida, que criam um clima onírico em que vemos a contaminação da mente do personagem pelas histórias e insinuações que compõem o espectro e que não cessam em nenhum lugar. Essa contaminação é sugerida pelo constante encadeamento do espectro (falas, notícias, ruídos etc.) e principalmente pelos momentos em que os pesadelos surgem: o primeiro após ouvir a história do Bartolomeu - "o baixinho da cantina" - que mata o traficante que ameaça dormir com sua esposa e o segundo na manhã seguinte à última festa na casa ao lado, noite em que Valter estava bastante apreensivo com Dimas.

\footnotetext{
${ }^{6}$ Alfred Schnittke compôs a música após a morte de sua mãe e, nessa cena, a canção reforça a tragédia do assassinato de Dimas.
} 
Ao longo da trama, junto aos atritos com os inquilinos, o espectro da violência vai ganhando força. Apesar de impelido e pressionado pela esposa para que aja e contenha os ruidosos vizinhos, a grande ação de Valter será receber uma pedrada de crianças, acidente que enfim contém a festa na casa ao lado e inspira orgulho no filho. O sangrento incidente é a primeira imagem de agressão que vemos no âmbito real da narrativa, isto é, fora da imaginação de Valter e aparece para anunciar a mudança que virá; deixando o lugar quase que exclusivo dos boatos, imaginação, ruídos e falas, a violência surgirá de modo mais concreto no fluxo da narrativa.

Na escola, o espectro da violência aparecerá primeiro com o alerta da diretora sobre as faltas em dias de ataques e então, de modo mais sólido retorna com o poema. Além de "A morte do leiteiro", na noite em que se segue a da pedrada, a calorosa discussão sobre "Uma nova poesia" (Ferréz) é encerrada com uma estrondosa explosão vista pela janela da sala de aula. Do lado de fora, membros do PCC armados com fuzis distribuem comida aos alunos. De volta a casa, Iara e Valter são acordados pelo inquilino que termina com as dúvidas do casal ao gritar: "Você precisa voltar e matar o maluco?".

Assim, o espectro se materializa como ação e sai do exclusivo espaço da TV, fofocas e imaginação. Após a pedrada, as chamas intensas no ônibus trazem os ataques reportados pela TV para o caminho percorrido por Valter. Depois, a morte de Evandro e, ao fim, a tragédia que, anunciada no início parecia apenas mais uma em meio a tantas suposições, se confirma: Dimas é assassinado pelos inquilinos. Mesmo com a confirmação de que os inquilinos são criminosos e com a morte de Evandro e de Dimas, a violência como imagem permanece como uma manifestação pontual que se insinua através das manchas de sangue. Ainda que continue sem aparecer em imagens, a violência, como espectro e ameaça constantemente presente no encadeamento das cenas, adquire contornos sufocantes. $\mathrm{O}$ ápice do sufocamento promovido pelo espectro é vivenciado por Valter após a prisão dos inquilinos, quando as especulações e boatos se multiplicam entre adultos e crianças, na rua 
e em casa.

Mantendo o tom do filme, não veremos nem o assassinato ser cometido nem o corpo de Dimas. Mesmo assim, nossa imaginação é intensamente povoada pelas incessantes e brutais falas das vizinhas, de Iara e das crianças que, por todos os lados, comentam o assassinato, narrando em detalhes o estado do corpo e a crueldade dos assassinos. Valter que, durante o dia, tentara em vão se esquivar das tétricas descrições que lhe rodearam, não encontrará paz também na cama onde Iara continua: "Dizem que ele 'tava' todo cortado Valter, Seu Dimas todo fatiado, arrancaram o nariz dele, tiraram os dedos". Asfixiado com a fala, Valter se levanta e parte para o outro lado do muro. Essa será a única cena em que ele atravessa a fronteira e parte para o espaço da "outra cena" e será também o único momento em que a nossa visão se descola explicitamente do olhar do personagem. Após ver o cenário do crime (a casa de Dimas), Valter se dirige ao local onde moravam os criminosos. A ação é interrompida quando Valter percebe que é observado por Iara que o espia da janela da cozinha. Essa é a primeira vez que nós e Valter vemos o contraplano da janela de sua casa. Do outro lado do muro, da posição onde se encontravam os inquilinos, Valter recebe o enorme e interessado sorriso de Iara. Após esse plano, passamos para a manhã do dia seguinte, sem saber o que Valter viu na casa ao lado, se é que viu algo.

Figura 2

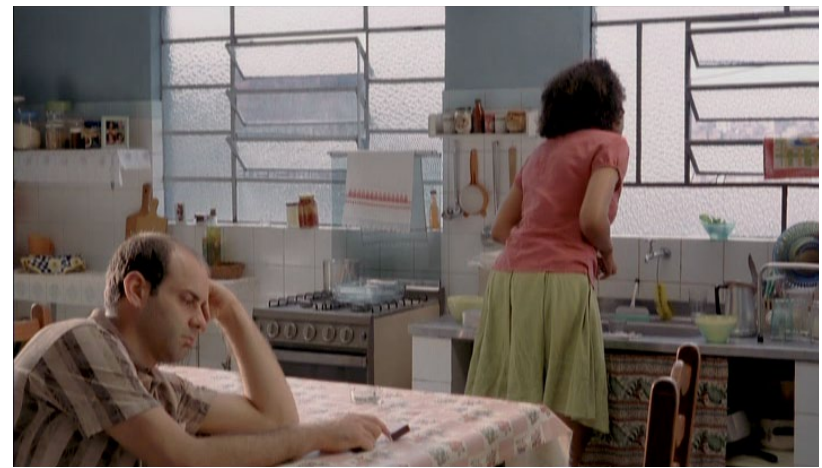

Figura 3

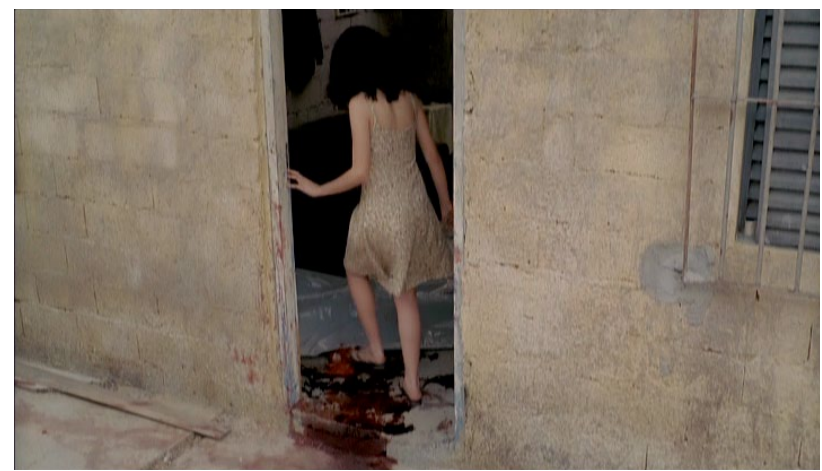


Nessa sequência final, a cena que fecha o filme é de grande brutalidade. No dia em que se segue ao assassinato de Seu Dimas, na saída ao trabalho, Valter passa por Consuelo - ex-mulher de Dimas que esfrega o chão na porta ao lado, limpando o sangue com impassibilidade. A imagem é duplamente violenta: à quantidade de sangue que ela esfrega se soma a indiferença de seus gestos e de sua fala que, num diálogo vazio, um tanto automático, pergunta sobre as crianças e a esposa. Torcendo o pano em que escorre sangue, ela

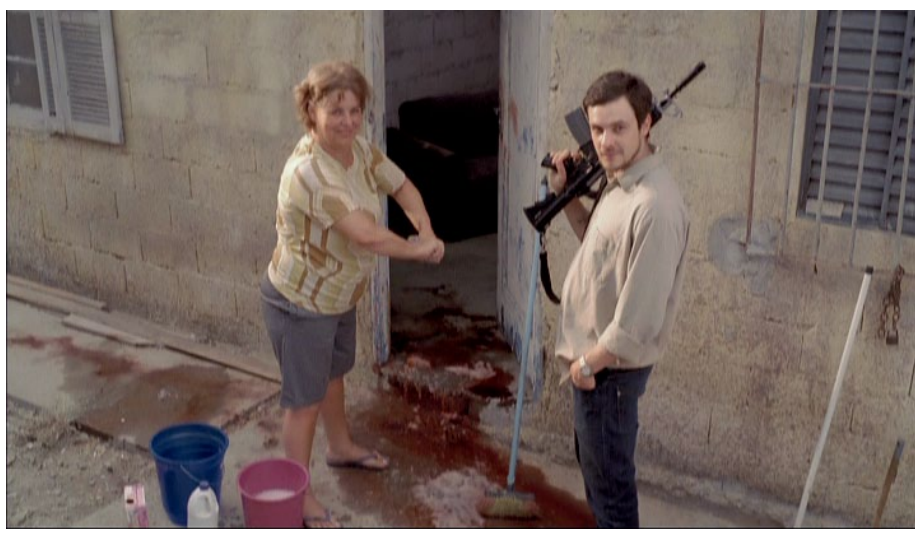

Figura 4

Valter encontra com Consuelo e inquilino na saída de casa.

sorri e diz: "Sujeirada 'né’? 'Tá'

chegando pessoal novo. Agora o jeito é esfregar, limpar, lavar". Vemos que o pessoal novo, assim como o inquilino que não fora preso (que acompanha Consuelo, sorri e pisca pra Valter), são membros do PCC e agora, desfilam com fuzis.

Sem reação - entre a paralisia e o horror, Valter se vira e segue o caminho para o trabalho, se distanciando ao longo da rua. Seguindo o percurso inverso da primeira sequência, a câmera acompanha o personagem que se mistura à pequena multidão que caminha no mesmo sentido que ele ao longo da rua de cima. Com o enquadramento que remete ao do início, voltamos a ouvir Un Grand Sommeil Noir, que, após os primeiros acordes em voz grave, continua "un grand sommeil noir; tombe sur ma vie" (um longo sono negro; cai sobre minha vida). Reiterando a circularidade, sem indicação de melhoras e sem horizonte (como muitos enquadramentos), o filme se encerra e, perante o conflito com os vizinhos, com ironia o subtítulo ecoa "os incomodados que se mudem". 


\section{São Paulo-Bairro: cotidiano em conflito}

A São Paulo de Inquilinos é composta pelo bairro onde os personagens vivem, pelo local onde Valter trabalha e estuda e pelos discretos trajetos entre esses três ambientes. Do alto, o ambiente de trabalho nos é apresentado pelo plano aéreo no qual os galpões do Ceasa estão rodeados pela eclética paisagem urbana composta por uma camada de árvores e outra de prédios e, ao fundo, um arborizado morro (figura 5). No interior, o vestiário, o galpão onde Valter carrega caixas de maçã e o escritório do chefe compõem os espaços do turno de trabalho. Pela terra, a placa do coletivo nos informa que estamos na Zona Sul. Valter desce no que parece ser o ponto final da linha "Pinheiros-Valo Velho", caminhando até a escola através da rua de terra batida e, então, por paisagens entre casas e vendas com sinais de autoconstrução que caracterizam os espaços periféricos (figuras 6 a 8).

Figura 5
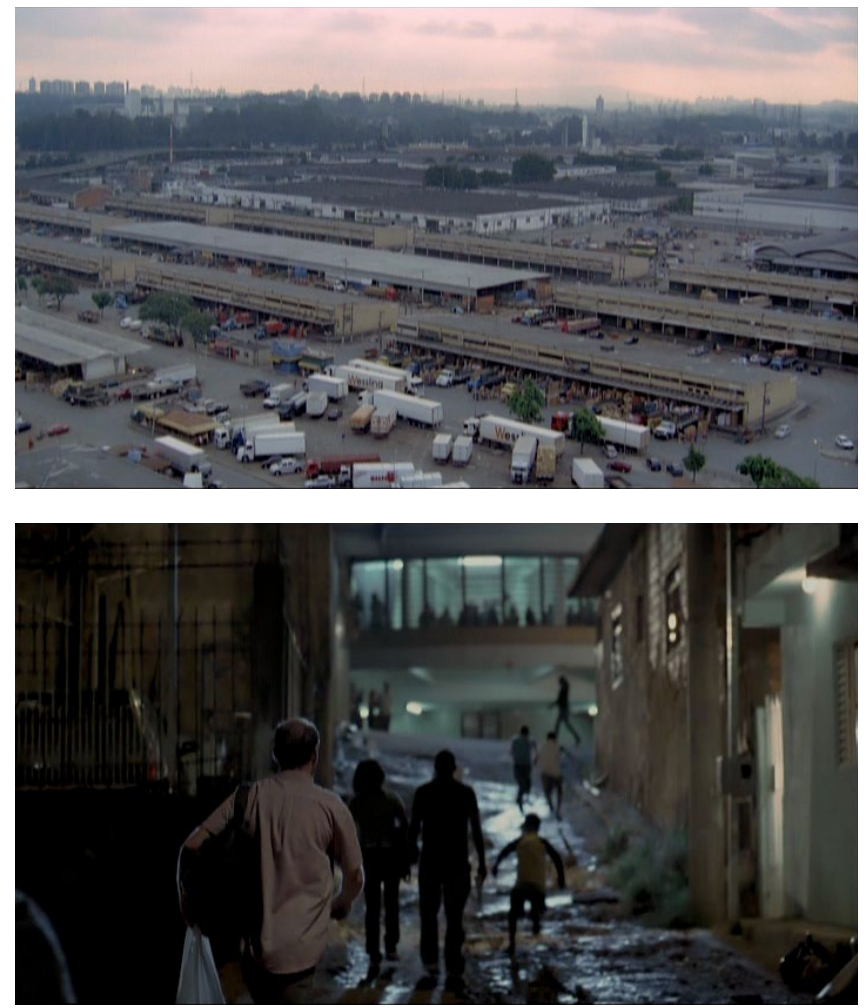

Figura 7
Figura 6
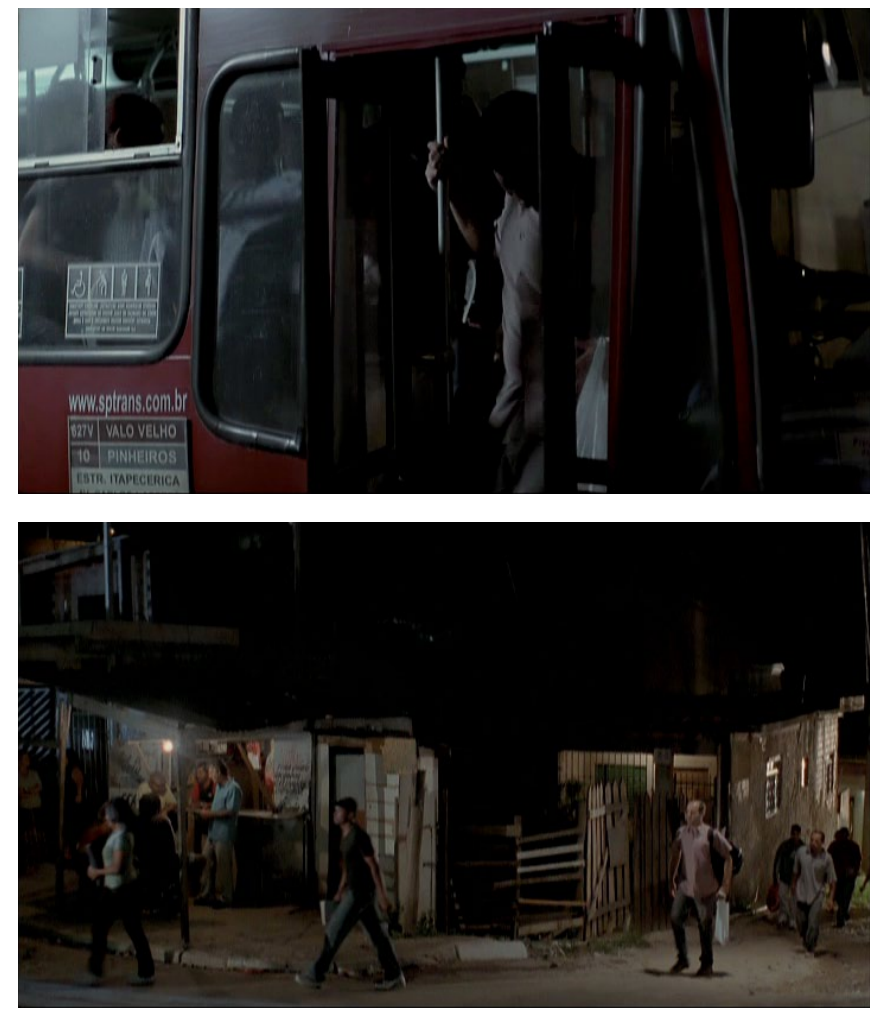

Figura 8 
A caminhada para o ponto de ônibus no bairro e do ponto de ônibus para a escola ajuda a construir as elipses que omitem os trajetos e também a reforçar o sentido do constante deslocamento diário. Por vezes a caminhada matinal ao ponto é imediatamente seguida pela chegada à escola (de noite) ou por sua volta a casa no fim do dia. A imensidão da cidade fílmica surge não através das distâncias literalmente percorridas pelos personagens - como no constante trânsito por viadutos, estradas e avenidas vistos em Salve Geral -, mas através das diversas elipses e dos planos emblemáticos que indicam pontos extremos da cidade. Diferentemente dos dois filmes anteriores, aqui não há cartões-postais paulistanos nem avenidas conhecidas (como Paulista, 9 de Julho e 23 de Maio). O constante ir e vir de Valter que passa de uma periferia a outra pode ser pensado como uma das características que confere identidade à cidade de São Paulo vista em Inquilinos.

De modo diferente do Ceasa, apresentado com plano aéreo, e do Valo Velho, informado pela placa do ônibus, o bairro onde a família vive não tem sua localização identificada e surge no filme como uma região genérica. $\mathrm{O}$ bairro escolhido para abrigar a maior parte das filmagens - onde a equipe literalmente construiu a casa da família de Valter - tem relativa recorrência no cinema paulistano. Sem uma fisionomia marcante como a dos morros cariocas, nos anos 80, com feições bastante distintas das décadas seguintes, a Brasilândia foi o cenário principal em Eles Não Usam Black Tie (Leon Hirszman, 1981) e nos anos 2000 aparece em diversos títulos da vertente da Retomada que abordam a violência urbana. Além de Inquilinos, o bairro é o espaço principal de Contra Todos (Roberto Moreira, 2004) e Antônia (Tata Amaral, 2006), e aparece também em uma cena de Invasor (Beto Branti, 2001). A intensa topografia acidentada e acentuada (a Brasilândia é composta por uma série de morros e sub-regiões) e a relativa proximidade do bairro com a região central podem ser pensadas como alguma das razões para a recorrência do bairro como locação. Mesmo com a reincidência do bairro em diferentes tramas, de acordo com a imensidão e pluralidade da região, a Brasilândia terá, em cada filme, uma feição diferente. Apesar 
do anonimato do local no filme, a narrativa preserva características do bairro, como o contraste entre as classes populares e as sub-regiões que abriga.

Além de fornecer a estrutura, o cotidiano (fortemente atrelado ao bairro) confere o compasso do filme não apenas pela sucessão de ações, mas também através da forma fílmica. Com os sons do dia a dia que permeiam as trilhas clássicas e se combinam com elas, com enquadramentos e movimentos de câmera estáveis (tanto na composição quanto na duração), e com a tonalidade pastel presente na casa e em figurinos da família de Valter, se configura um clima que, a despeito do espectro da violência constantemente presente, é (vigorosamente) ameno.

Além das ações que se repetem, o modo como elas nos são mostradas reforçam a noção do cotidiano rigorosamente ligado ao bairro e a casa: a volta de Valter para o lar pela mesma ladeira em enquadramentos que se assemelham ou parecem manter a continuidade, as despedidas e chegadas no portão e os tardios jantares ao lado de Iara em planos parecidos constroem imageticamente a repetição diária que dá ritmo e que move a trama. As elipses que omitem os trajetos corroboram também com o ritmo dilatado e com a construção da importância do bairro na narrativa. O bairro, composto pelo lar da família, pela casa ao lado - disponível ao olhar e pelas ruas da frente e do lado, é o espaço central da narrativa, a locação da maior parte das cenas, onde o filme se inicia e termina. Em Inquilinos, a construção espacial do bairro e também da casa são elementos importantes às críticas articuladas no filme.

Na casa, a sala e a cozinha serão os cenários mais explorados (os quartos e banheiro aparecem de modos bastante discretos). Tanto na sala quanto na cozinha as janelas figuras caras à construção da narrativa, à configuração espacial e da mise-en-scène - terão bastante destaque e dominarão algumas cenas. Na cozinha, onde a família toma o café da manhã e onde Valter janta ao lado de Iara (refeições que se avolumam no longa) o destaque para a janela com a vista para o quintal ao lado será recorrente (como nas figuras 19 a 

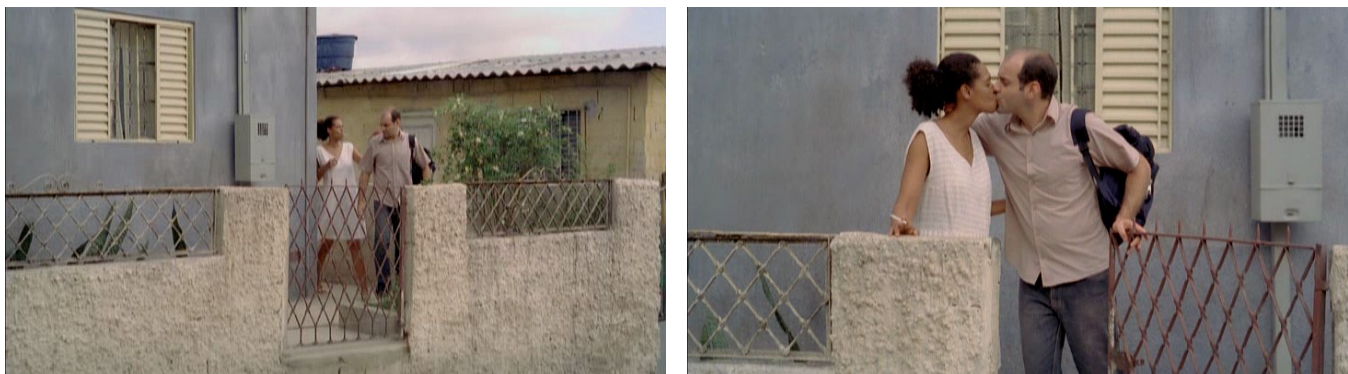

Figuras:
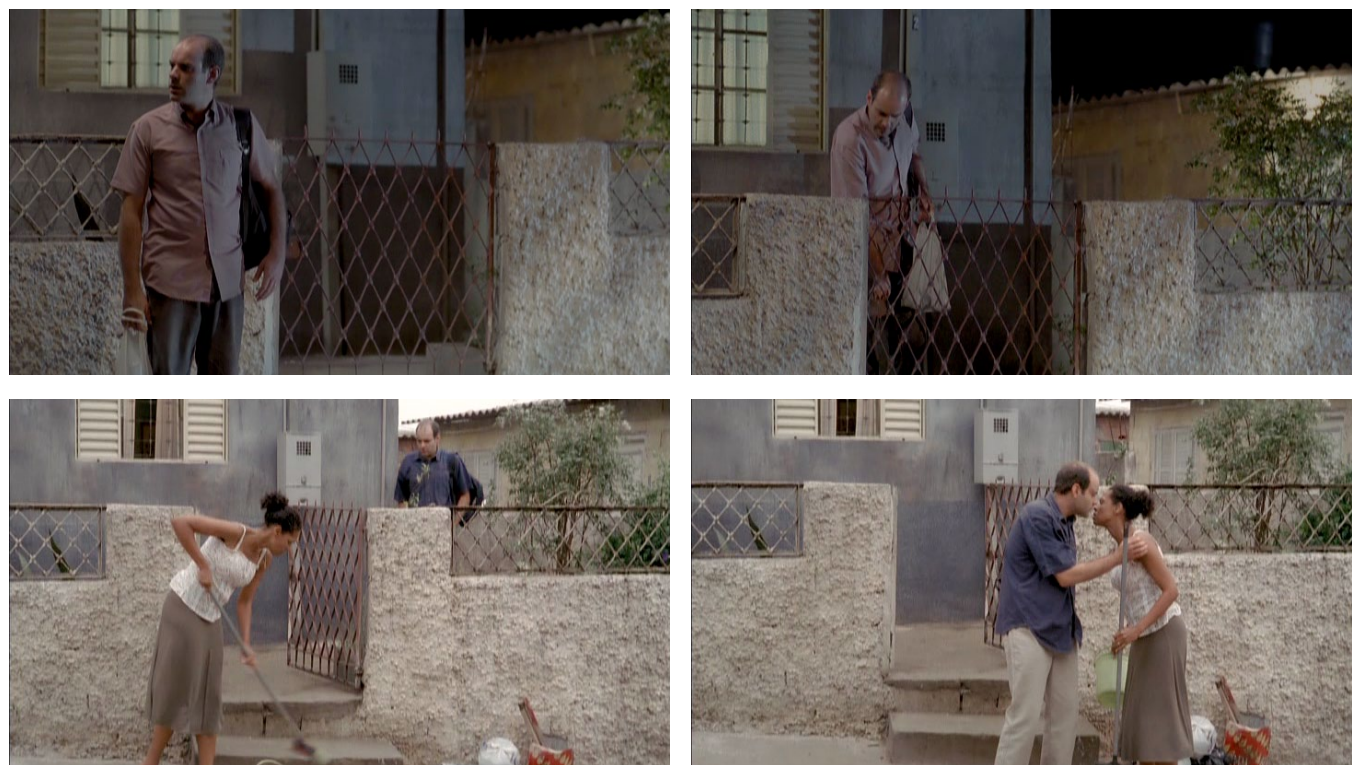

Acima: Valter sai na primeira manhã (figuras 9 e 10). No meio, a volta na segunda noite (figuras $11 \mathrm{e}$ 12). Abaixo, a manhã seguinte à revelação de que os inquilinos mataram alguém (figuras 13 e 14).

De cima para baixo: Valter volta da escola na segunda noite (figura 15) e antes da festa em que recebe a pedrada (figura 16) - parece haver continuidade entre os planos. De dia, a volta para casa após o jogo de Diogo (figura 17) e, ao final, quando corre para casa com a notícia sobre a morte de Seu Dimas (figura 18).
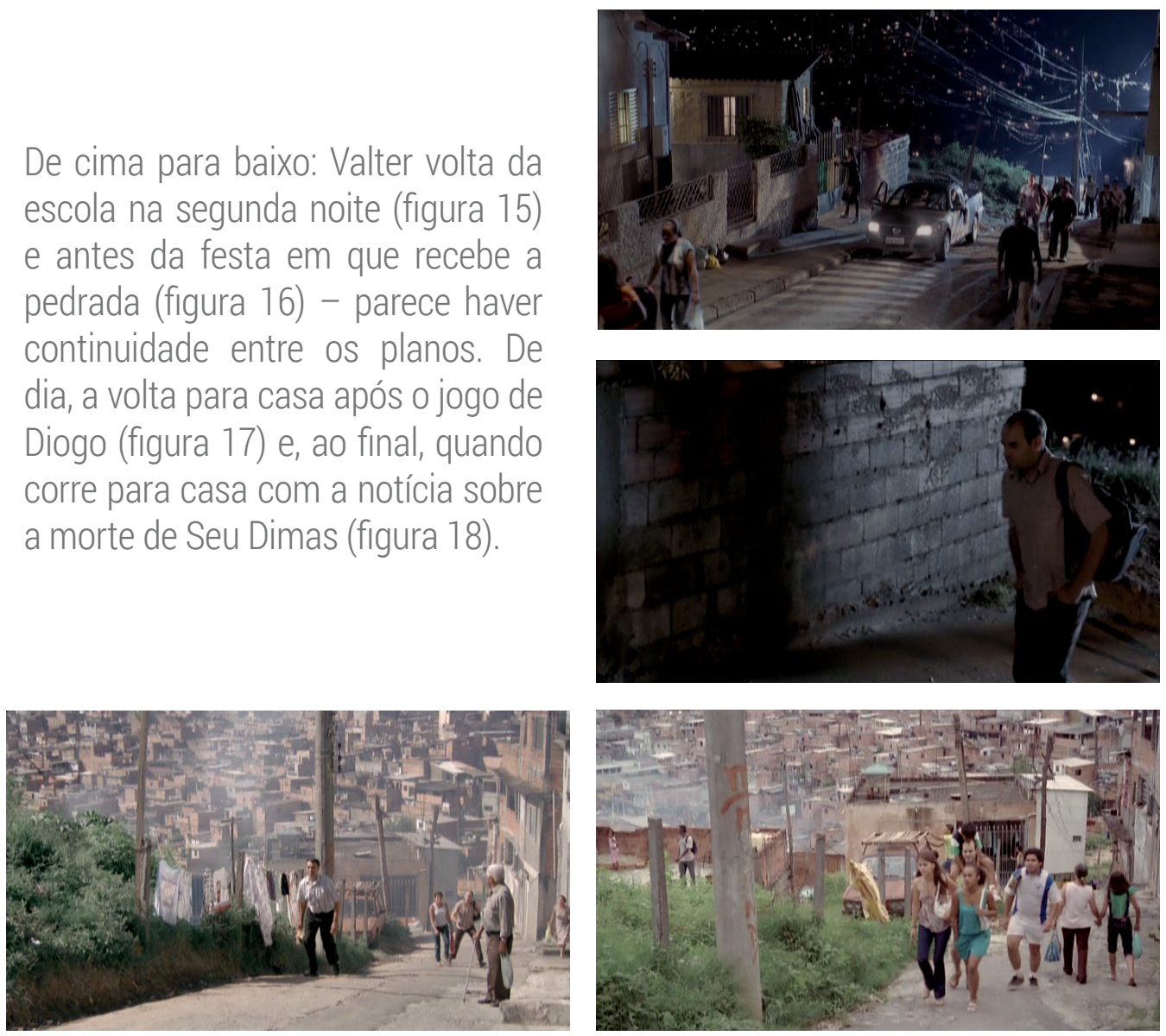
Figuras: A rotina no jantar, respectivamente, 1920 na segunda noite (figuras 19 a 22), $21 \quad 22$ \begin{tabular}{l|l|l}
23 & 24 \\
\hline
\end{tabular} no primeiro final de semana (figuras 23 e 24) e durante a festa que Valter \begin{tabular}{|l|l|}
\hline 25 & 26 \\
\hline 27 & 28 \\
\hline
\end{tabular} é impelido a terminar (figuras 25 a 28).
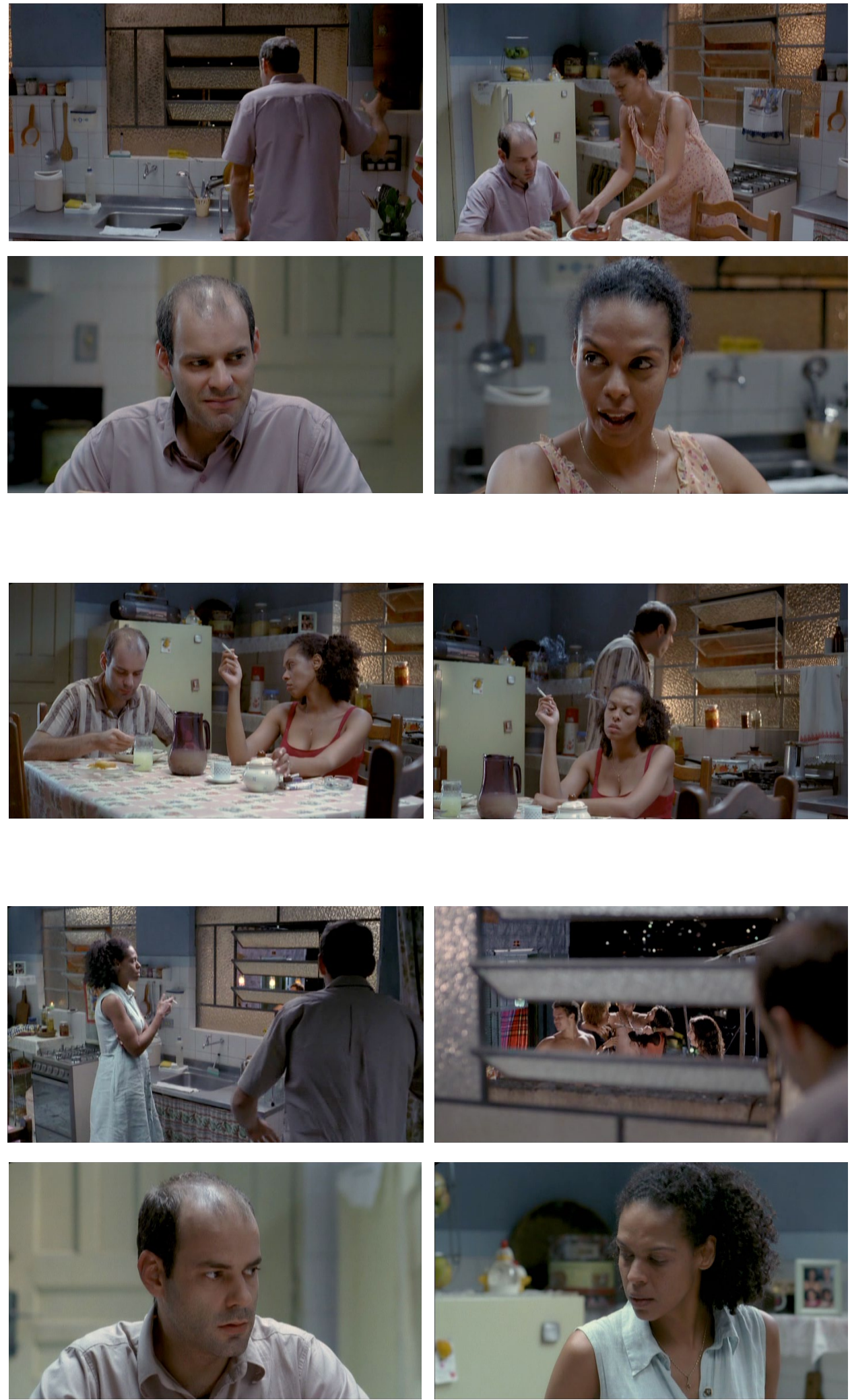
28). A janela chama Valter e Iara à ação (de espiar) e marca também seus movimentos e posições: não raro os personagens dão as costas para a câmera. Na sala, além da janela para a rua da frente - que oferece a vista para observarem os inquilinos que lhes despertam tarde da noite, a TV se constitui também como outra janela que transporta a família para outras cenas.

Nesse dia a dia (que é ação e linguagem) junto ao atrito que se anuncia com os novos vizinhos, o modo como os enquadramentos no bairro são constituídos expressam uma tensão que, sob esse ambiente acolhedor, se estabelece com o entorno. A chegada dos inquilinos não rompe com uma suposta harmonia vivida no bairro, mas representa $\mathrm{e}$ exponencia uma tensão latente entre os locais habitados pelos personagens centrais (casa, rua da frente e do lado) e a região que lhes envolve. Presente nos diálogos, essa tensão também se expressa com as imagens. As casas sem reboco que formam a primeira imagem do filme (que, de modo genérico, remetem às habitações irregulares, às favelas) não possuem qualquer referência sobre sua localidade na geografia construída no longa. Apresentada

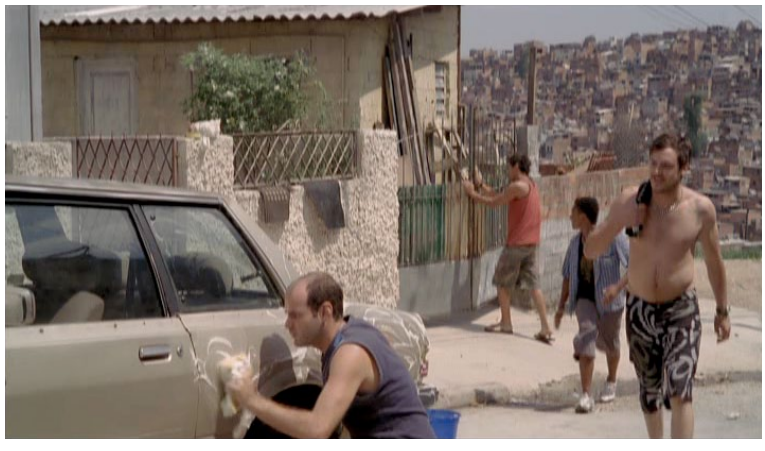

Figura 29

Valter lava o carro em frente

à sua casa - ao fundo a paisagem começa a se revelar. junto aos acordes do "longo sono negro" (Ravel/Verlaine), essa paisagem inicial contrasta bastante com as coloridas e diversificadas habitações que constituem a vizinhança de Valter (isto é, as casas da parte de cima da rua e da rua ao lado). Se num primeiro olhar poderíamos supor que o plano inicial não tem qualquer relação com o aprazível bairro, ao longo do filme, gradualmente, a fragmentada paisagem se completa e entendemos que o morro do início é a vista que podemos ter da rua de Valter, que também é cercada, desde a casa ao lado (de Seu Dimas) até a parte mais baixa, por casas sem acabamento. Pouco a pouco 
a vista começa a se revelar em planos como o da figura 29.

Como grande parte das tomadas externas diurnas no bairro se fecha nos limites das habitações (como nas figuras 32 a 34), essa paisagem que envolve a casa de Valter surge na maior parte do filme com bastante discrição, até que, sugerindo a ligação entre os personagens e esse espaço, após o plano dos inquilinos descendo a rua (figura 32) emerge a imponente paisagem do morro (figuras 30 e 31). A despeito do relevo da Brasilândia, a inclinação do bairro é relativamente pouco explorada através da rua em que Valter sobe e da paisagem ao fundo que vai se revelando (figuras 15 a 18; 30 e 31).

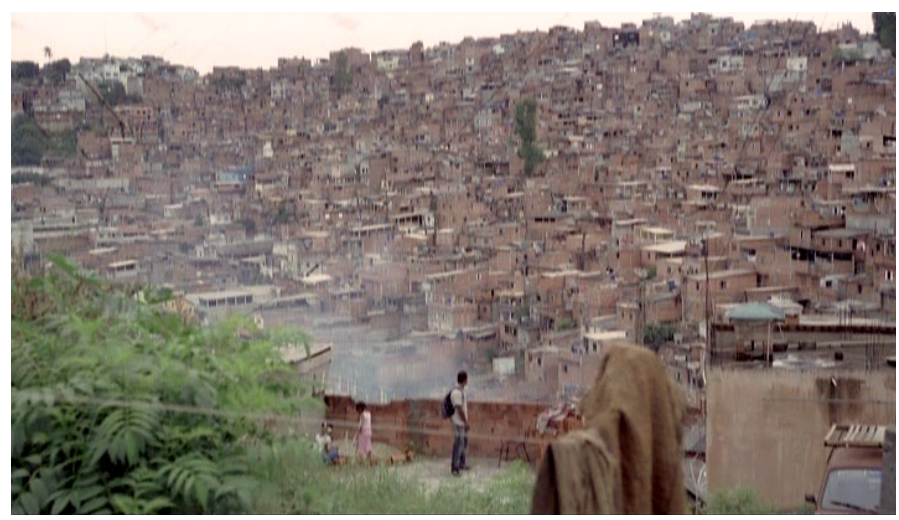

\section{Parte baixa e entorno do bairro: a vista da rua de Valter é a paisagem do primeiro plano do filme.}

Figura 31

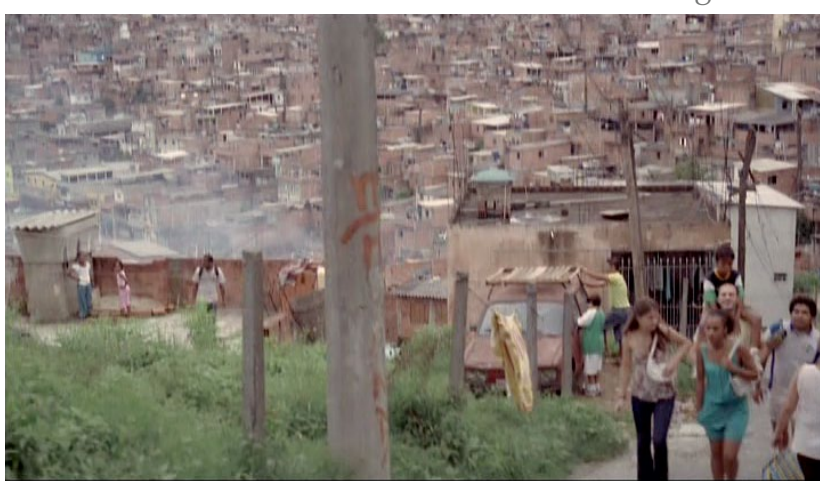

Ao mesmo tempo em que o recorte do quadro reforça a importância da casa e das ruas que lhe tangenciam, ele também isola e destaca o espaço de seu entorno, fechando o universo fílmico e resumindo o bairro nessa pequena vizinhança que está no topo do morro. Com os outros locais que aparecem pontualmente no turno da aula e do trabalho, a São Paulo de Inquilinos é formada especialmente por esse recorte no bairro. Essa construção também remete a uma São Paulo que se centra num reduto e ignora o entorno com o qual contrasta (como a famosa paisagem dos edifícios de luxo do bairro do Morumbi 
cercada pela imensa favela do Paraisópolis que lhe envolve). Como caso mais extremo e exacerbado da segregação, os enclaves fortificados formados por condomínios como os do Morumbi, centros comerciais e empresariais, separam os grupos sociais de modo explícito e transformam a qualidade do espaço público ${ }^{7}$.

O contraste entre as paisagens da vizinhança de Valter e da favela surge também nos diálogos em que a favela aparece como uma ameaça e como o espaço de onde deriva o mal. Conforme conta Iara, na favela ao lado foi encontrado o corpo da criança morta e violentada, mencionada na reportagem de Datena; é desse local de onde, supõem, vieram os inquilinos. A favela é também o local onde o casal teme que as crianças se aproximem. Apesar de estar ao lado, a favela - assim como os inquilinos - simbolicamente representam o mais distante de suas identidades; "isso daí é outra gente", fala Iara ao se referir aos festeiros e novos vizinhos.

Figura 32

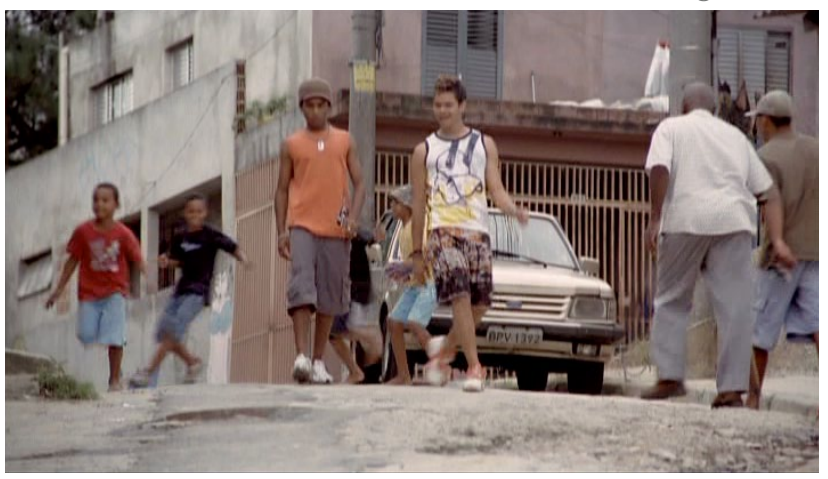

Figuras 32, 33 e 34 que, como os enquadramentos das saídas e retornos de Valter para casa (figuras 9 a 14), são fechados nos limites das habitações, revelando pouco do conjunto do bairro.
Figura 33

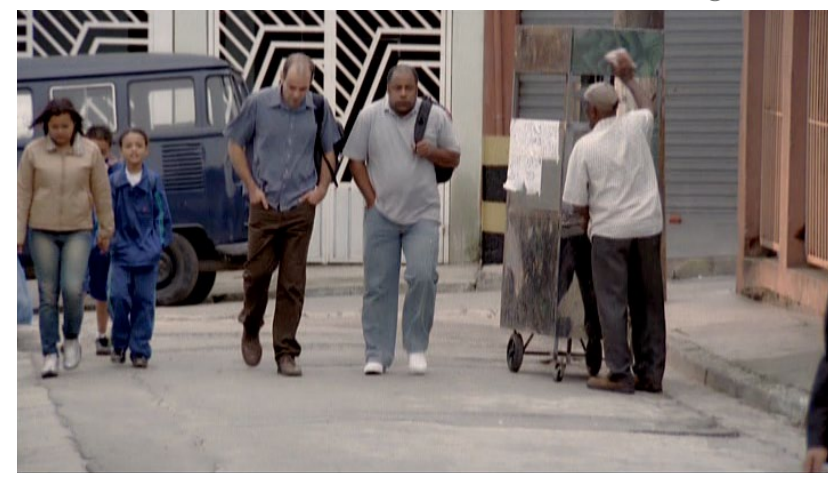

Figura 34

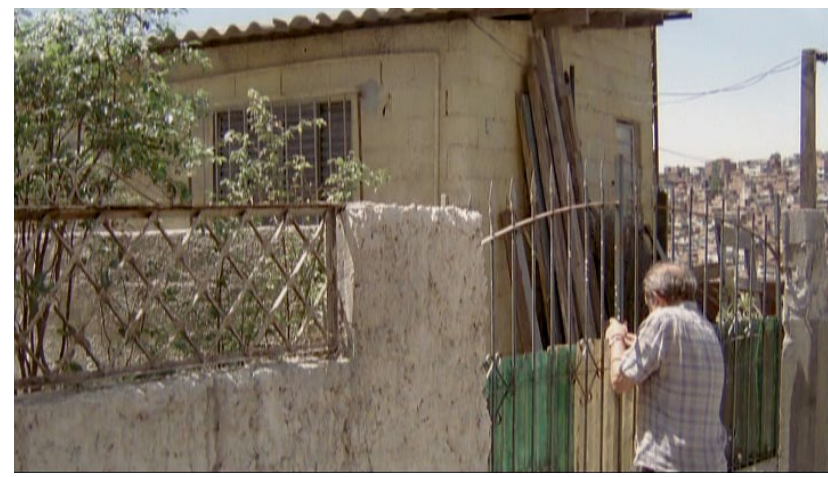

${ }^{7}$ CALDEIRA, Teresa Pires do Rio. Cidade de Muros: crime, segregação e cidadania em São Paulo. São Paulo: Editora 34, 2000. 
Mais do que um conflito entre vizinhos (temática que poderia sugerir a proximidade entre Inquilinos e Som ao Redor - Kleber Mendonça Filho, 2012 ${ }^{8}$ ), a chegada dos inquilinos dá visibilidade à tensão entre "nós" (família com quem podemos nos identificar) e "eles", um outro indesejado e temido. Além de se expressar pelas falas e olhares e pelo recorte (composição) dos quadros, esse conflito surge também com a trilha Un Grand Sommeil Noir que, sintomaticamente, ouvimos na primeira e na última imagem do filme. Corroborando com a interpretação de que o "longo sono negro" do poema surge desse outro indesejado (a favela da primeira imagem, os inquilinos que permanecem ao final), também ouvimos a música quando Valter imagina que sua esposa flerta com um dos novos vizinhos.

A escolha de não se centrar na favela pode apontar para a intenção de se esquivar do cenário que, muitas vezes, é apropriado de modo sensacionalista para mostrar "o pior do pior". Mais do que isso, a escolha permite colocar em pauta o conflito e o preconceito vividos também entre a camada mais pobre da população que, como a classe empresarial de Inversão não é solidária com seus pares, mais ou menos pobres. O recorte nessa família cercada pela favela também permite problematizar as diferenças no estrato popular que não surge aqui homogeneizado. Apesar de o casal estar um degrau acima na pirâmide social, eles sofrem de uma violência estrutural associada à desigualdade e à exploração (expressa nas discussões em sala de aula e nos diálogos com o chefe de Valter que não assina sua carteira de trabalho). Mesmo assim, Valter e Iara perpetuam também a segregação pelas falas que são endossadas pelo recorte do quadro que segrega bairro e favela. Se a ação de elaborar preconceitos e marcas de distinção social é comum a todas as classes, a proximidade física pode tornar a segregação simbólica ainda mais intensa: "as depredações mais explícitas

\footnotetext{
${ }^{8}$ A aproximação entre os títulos foi sugerida por Cléber Eduardo no debate "Deslocamentos e espaços na produção independente: novos segmentos estilísticos no cinema brasileiro" (mai. 2014) - atividade organizada pelo Grupo de Estudos História da Experimentação no Cinema e na Crítica. Todavia, diferentemente do conflito entre a vizinhança de classe média do Recife que se agride (Som ao Redor), aqui há uma distinção social expressa nas próprias edificações: os vizinhos não são do mesmo estrato social.
} 
e veementes surgem quando a proximidade e a ameaça da mistura aumentam" ${ }^{\text {. Nesse }}$ sentido, o recorte no quadro e as falas operam como refinamentos que mantêm a percepção da diferença.

\section{0 espetáculo ao lado e o espectador-personagem}

Apesar de indesejado e às vezes temido, o outro (como construção) e a violência virtual geram um fascínio. A forte atração, o medo e a curiosidade sobre os inquilinos, histórias, notícias e boatos sobre a violência são compartilhados entre adultos e crianças, mas se expressam de modos mais intensos com Iara, personagem que, sintomaticamente, deixa a casa apenas uma vez para ir com Fernanda à festa do outro lado da rua. Se seu lugar é dentro da casa, a TV, as fofocas e a janela são seu acesso ao mundo: inaugurando a privilegiada vista da janela da cozinha, Iara é quem mais se interessa pelos rumores (que vêm) de fora.

Seu olhar ao outro lado do muro contém um misto de vigilância (ou bisbilhotagem) e sedução, insinuando uma relação dúbia que, apesar de não se realizar, corrobora com a imaginação de Valter. Após a prisão dos vizinhos, quando Valter passa para o outro lado do muro, ele vê da perspectiva dos inquilinos a figura de voyeur sensual da esposa atraída e fascinada pela outra cena. A hipótese de que, em sua ausência, Iara flerte com os inquilinos atormenta Valter e torna a figura dos jovens vizinhos ainda mais ameaçadora e incômoda ao insinuar que a invasão ocorra também na sua relação conjugal.

A outra cena que tanto atrai Valter, Iara e nós é diametralmente oposta à rotina familiar: é a cena dos jovens que não trabalham, fazem festa, "levam mulher"; é cena do

\footnotetext{
${ }^{9}$ CALDEIRA, Teresa Pires do Rio. Cidade de Muros: crime, segregação e cidadania em São Paulo. São Paulo: Editora 34, 2000, p. 75.
} 


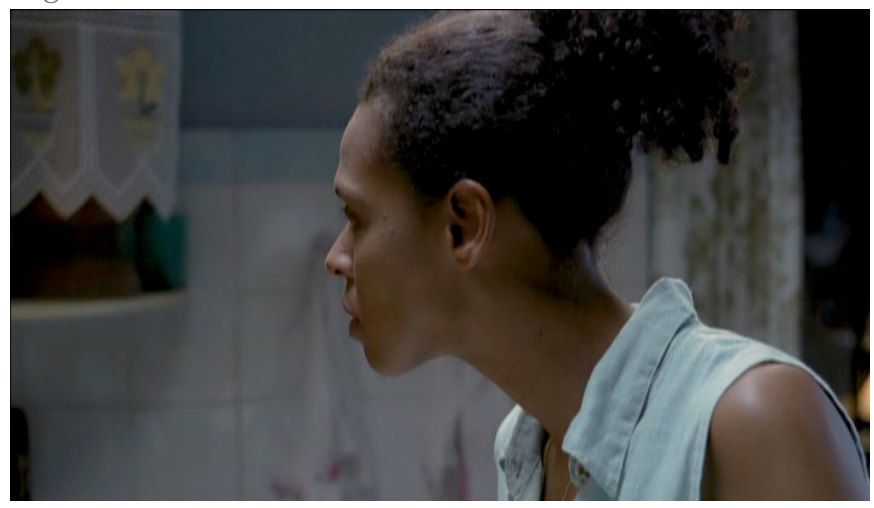

Figura 36

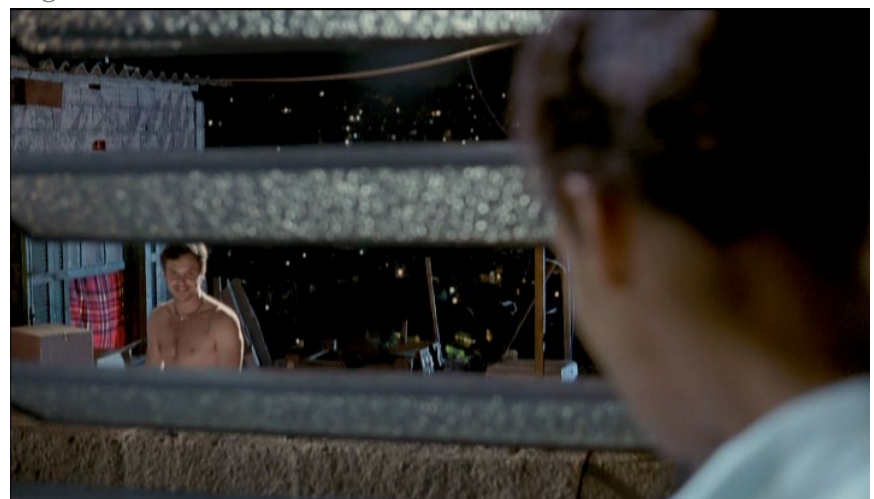

lara inaugura o olhar para o quintal ao lado onde o inquilino se exibe sem camisa, num misto de vigilância e sedução.

crime. Se o fascínio pela outra cena e a explicitação das regras do jogo do olhar e da cena remetem a Hitchcock (em especial em filmes como Janela Indiscreta e Vertigo [Um corpo que cai]), contrariando aquilo que, com recorrência, é apontado como padrão - e que reaparece nos filmes do diretor britânico, aqui o olhar fascinado é feminino e a figura que seduz e que se oferece como objeto do olhar é masculina.

Além de Iara, ao longo da trama são inúmeros os momentos em que vemos os demais personagens posicionados como espectadores (extremamente) interessados com o que se passa lá fora, na casa ao lado e, às vezes, com aquilo que é transmitido pela TV. A TV e a janela (meios pelos quais Valter, Iara e os filhos se relacionam com o que se passa ao redor de sua casa e na cidade), reproduzem as "janelas para o mundo" - perspectiva consagrada na pintura e que se manteve na foto, na TV e também no cinema. Essas janelas de diferentes naturezas colocam em pauta a dinâmica do espetáculo e problematizam também a nossa posição de espectadores, em especial, de notícias e narrativas de violência. 
Figura 37

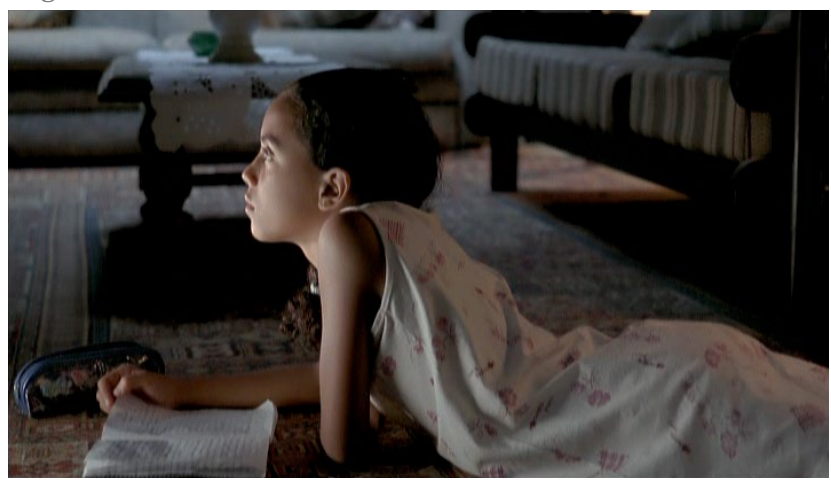

Figura 39

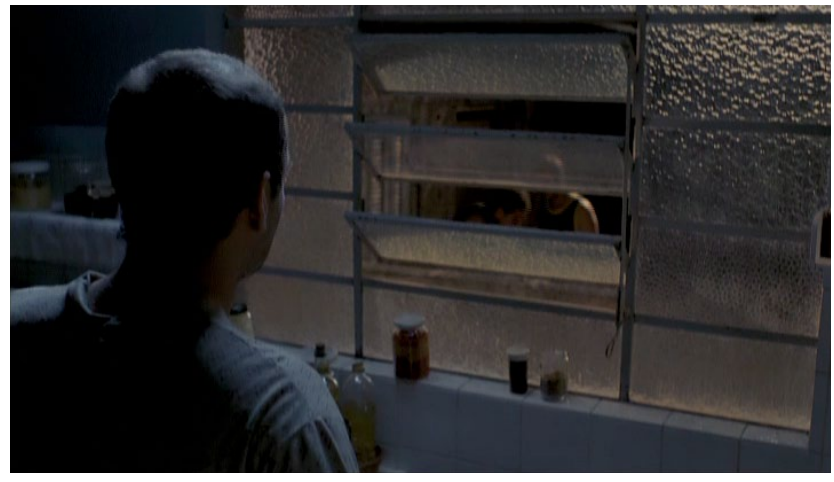

Figura 38

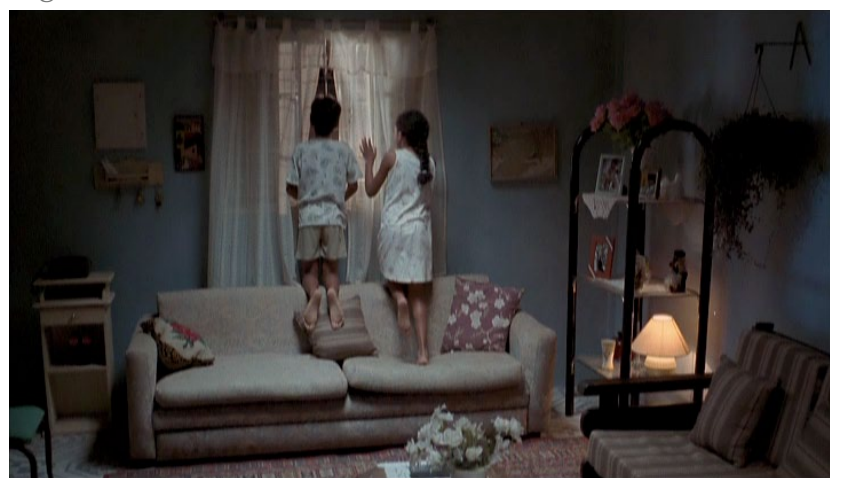

Figura 40

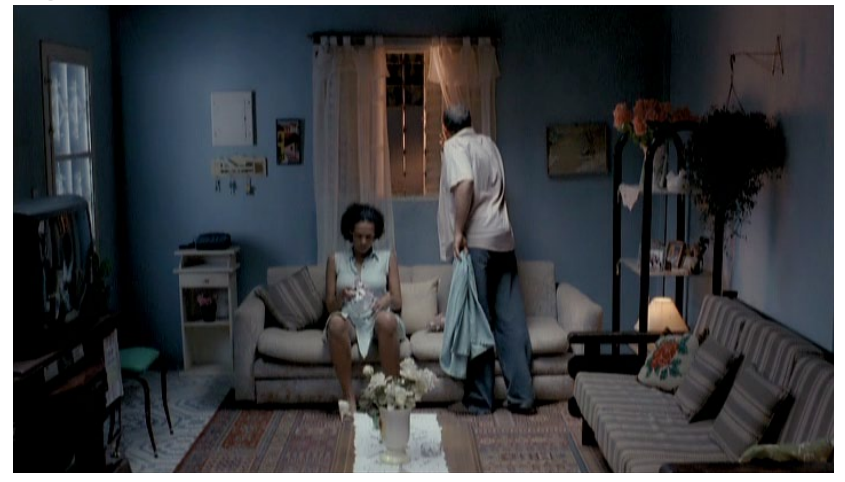

Em diversos momentos os personagens aparecem como espectadores que assistem ao que se passa na TV (figura 37), mas, principalmente, a outra cena que as janelas Ihes oferecem (figuras 38 a 40).

Fundada sobre regras matemáticas, a perspectiva renascentista ofereceria uma imagem "correta, ordenada, hierarquizada, mensurável e harmônica"10 do mundo, criando a ilusão de profundidade numa superfície plana que introduz a contiguidade do espaço da representação e do espectador. Assim, o quadro se abre como uma janela para o mundo ${ }^{11}$ e a perspectiva aparece em seu sentido original pleno, isto é, como "ver através". A janela é a moldura, mas também é a posição que delimita o campo da visão e situa o espectador ${ }^{12}$.

No cone visual da representação, o olho do espectador representa o vértice que se une

\footnotetext{
10 JORGE, Luís Antônio. O desenho da janela. São Paulo: Annablume, 1995, p. 56.

11 Expressão de Alberti, um dos responsáveis por sistematizar a perspectiva. Cf Jorge (1995).

12 JORGE, Luís Antônio. O desenho da janela. São Paulo: Annablume, 1995, p. 56.
} 
à base da pirâmide (a imagem vista) através dos feixes de luz ${ }^{13}$. A noção de colocar o espectador diante dessa janela que se abre para o mundo, de transportá-lo para além de sua capacidade física marcou também a fotografia cujo surgimento foi proclamado como a objetivação tecnológica do princípio de representação renascentista. Cinema e TV (que também seguem o esquema de representação) são, ainda nos dias de hoje, referidos como "janelas para o mundo".

Nesse sentido, os constantes olhares lançados pelos personagens aos inquilinos remetem à geometria do olhar e da cena - herdeira da perspectiva renascentista e que, portanto, antecede o cinema, mas que nele se consolida, instituindo socialmente uma forma de olhar ${ }^{14}$. Essa geometria - que se insere na tradição do espetáculo -, compreende a concepção espacial em que espetáculo e plateia encontram-se separados por uma fronteira que pode ser pensada como uma moldura, justamente a janela que dá acesso ao mundo, ou melhor, à cena que se desenvolve para o olhar do espectador ${ }^{15}$.

Como que dialogando com essa tradição, é literalmente a janela que oferece a Iara e Valter o meio para que, com privilégio, possam observar os jovens. Todavia, distante do "efeito janela" que coloca o espectador na posição de voyeur diante de um mundo autônomo que é percorrido por um olhar astuto ${ }^{16}$ e sem corpo em sentido pleno ${ }^{17}$, que salta no espaço e no tempo rumo aos pontos de vista mais privilegiados, em Inquilinos a janela não é uma metáfora, mas sim uma condição física do campo visual do casal.

\footnotetext{
13 Ibid. p. 46.

${ }^{14}$ XAVIER, Ismail. O olhar e a cena: melodrama, Hollywood, Cinema Novo, Nelson Rodrigues. São Paulo: Cosac Naify, 2003, p. 11.

${ }^{15} \mathrm{Ibid}$. p. 62. Apesar das aproximações entre o esquema olhar-cena na pintura, no teatro e no cinema, essa semelhança não significa uma simples e necessária evolução rumo à representação realista coroada com o cinema. Ao longo da história, cada esquema de visualidade esteve (e está) essencialmente conectado às mudanças no estatuto do observador que correspondem às alterações sociais, discursivas, tecnológicas e institucionais. (Cf CRARY, Jonathan. Técnicas do observador: visão e modernidade no século XIX. Rio de Janeiro: Contraponto, 2012, p. 13; 15; 110).

${ }^{16}$ XAVIER, Ismail. O discurso cinematográfico: a opacidade e a transparência. São Paulo: Paz e Terra, 2005, p. 22.

${ }^{17}$ XAVIER, Ismail. O olhar e a cena: melodrama, Hollywood, Cinema Novo, Nelson Rodrigues. São Paulo: Cosac Naify, 2003, p. 37; 45.
} 
Como no quadro que se abre para o mundo, a vista das janelas da casa dá acesso a outra cena. Esse acesso é trabalhado em Inquilinos com certa ironia, pois, distante do olhar sem corpo da decupagem clássica, os personagens veem, mas não veem muito e é justamente a dificuldade de visão que confere boa dose do mistério do filme. Colados (em especial) no ponto de vista do casal, nosso olhar de espectador não penetra o outro lado do muro, a intimidade e os mistérios dos inquilinos; permanecemos presos junto às limitações físicas de Valter, com quem compartilhamos os conhecimentos e desconhecimentos sobre o mundo que lhe cerca.

Assim como o casal vemos apenas fragmentos de ações que pouco revelam sobre a principal suspeita da família. Cercados de mistérios e suposições, mesmo com a confirmação de que são de fato criminosos, essa "aura" em torno dos inquilinos permanece ao longo de todo o filme. Além de ser fundamental na estruturação do universo fílmico, essa posição aponta para uma construção dos inquilinos que é bastante singular. Sem nome, passado ou motivações, como na história do livro que é resumido por Fernanda - em que os bandidos eram maus simplesmente porque eram maus -, apenas sabemos que os jovens locatários são maus, bagunceiros e ponto. Essa visão distanciada dos inquilinos corrobora com o instigante mistério, mas também reforça a distância entre "nós" (família de Valter) e "eles" (inquilinos) - essa "outra gente" da favela que se parece com a figura do criminoso recorrentemente construída pela mídia.

À disposição da vista, mas nunca sujeitos do olhar (ou do ponto de vista que nos é oferecido pelo filme), surgindo em função da mirada de Valter e Iara - ou inversamente, chamando por ela através dos estrondos e ruídos -, os inquilinos constroem como que uma cena dentro da cena e, através da janela, se oferecem como espetáculo ao olhar dos personagens e, por consequência, ao nosso olhar que também está fascinado por essa outra cena. Apesar das aproximações com o esquema do espetáculo, longe da rígida separação entre os que observam e os que são observados, em Inquilinos espectador e espetáculo estão 
lado a lado em espaços contingentes que se invadem pelos sons e olhares e, diferente da garantida segurança do espectador cinematográfico, a família de Valter está sob o potencial risco de ser tomada pela violência que observam e temem. Mas, permanecendo como espectadores, não intervindo na outra cena, ao fim, o casal e seus filhos sairão ilesos.

A geometria tradicional do espetáculo se rompe também quando o espetáculo (inquilinos) se mostra e devolve o olhar aos interessados espectadores-personagens. Diferente de uma cena que se apresenta absorvida em si, os inquilinos se mostram conscientes de sua espetacularidade e, além de devolverem o olhar num misto de sedução e interação com a curiosidade de Valter/Iara, eles se exibem ao olhar e gritam aos vizinhos como que assumindo o "real exibicionismo de sua cena"18, reforçando o significado original do espetáculo, isto é "fazer ver", "deixar-se ver"19. Diferente do sujeito acuado pela mira do olhar vigilante, espetáculo e vigilância se sobrepõem ${ }^{20}$ : sabendo que são espiados, os inquilinos se exibem - sugerindo uma sedução pelo olhar. Nessa combinação, o antigo pesadelo do panóptico se atualiza como forma de entretenimento em que "(...) a figura da vigilância contínua e opressiva se traveste de uma amena cumplicidade de voyeur e exibicionista" e, invertendo o sentido da vigilância, passamos de objeto a sujeitos do olhar em um sistema em que somos convidados a tudo ver ${ }^{21}$.

Num tom crescente, a postura de voyeur é coletivizada e exacerbada no trecho final do filme. Para acompanhar a prisão dos inquilinos os moradores se aglomeram em frente a casa de Dimas e à plateia, um dos inquilinos grita "Ae" cachorrada, vem lamber o

\footnotetext{
${ }^{18}$ Ibid., p. 18.

${ }^{19}$ CHAUÍ, Marilena. Simulacro e poder: uma análise da mídia. São Paulo: Perseu Abramo, 2006, p. 14.

${ }^{20}$ Crary desenvolve o argumento contra a rígida separação entre espetáculo e vigilância defendida por Foucault ao analisar aparelhos ópticos do início do século XIX. Apesar de surgirem como instrumento de investigação da visão, campo que será importante na regulação e no controle do corpo, os mesmos aparelhos (em especial o fenacistoscópio e o esteroscópio) se tornaram populares objetos de entretenimento (Cf Crary, 2012, p. 26).

${ }^{21}$ XAVIER, Ismail. O olhar e a cena: melodrama, Hollywood, Cinema Novo, Nelson Rodrigues. São Paulo: Cosac Naify, 2003, p. 10.
} 
sangue que sobrou aqui, 'tá' fresquinho! (...) Vocês querem ver o 'coro comendo, né'?" A seguir, o entretenimento constituído pelo olhar lançado ao outro lado do muro é dividido com as vizinhas que vêm conhecer o privilegiado ponto de vista do casal. $\mathrm{Na}$ cozinhacamarote, bastante impressionadas com a vista ("Nossa, parece que a gente 'tá' lá dentro", diz Fátima), entre susto e o medo, o deleite com a fofoca é comum a todas que, com certo frenesi, compartilham o que sabiam ou imaginavam, e se deliciam também com a detalhada narrativa e com o teatro de Iara. Essa postura de voyeur que se acentua e generaliza (postura que parece haver sido autorizada com a confirmação do crime), configura um fascínio de dimensão gigantesca e doentia, que faz do espectro da violência um elemento bastante incômodo e sufocante.

\section{A plateia-vizinhança se posiciona em frente a casa de Dimas para assistir a prisão dos inquilinos (figuras 41 e 42).}

Figura 41
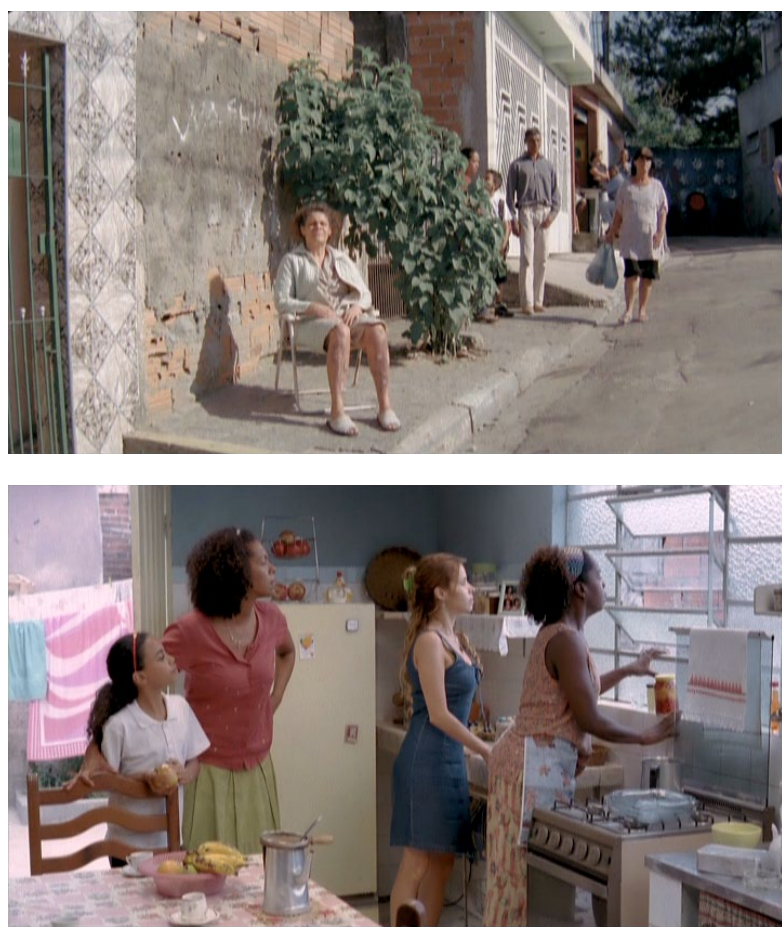

Figura 43
Figura 42
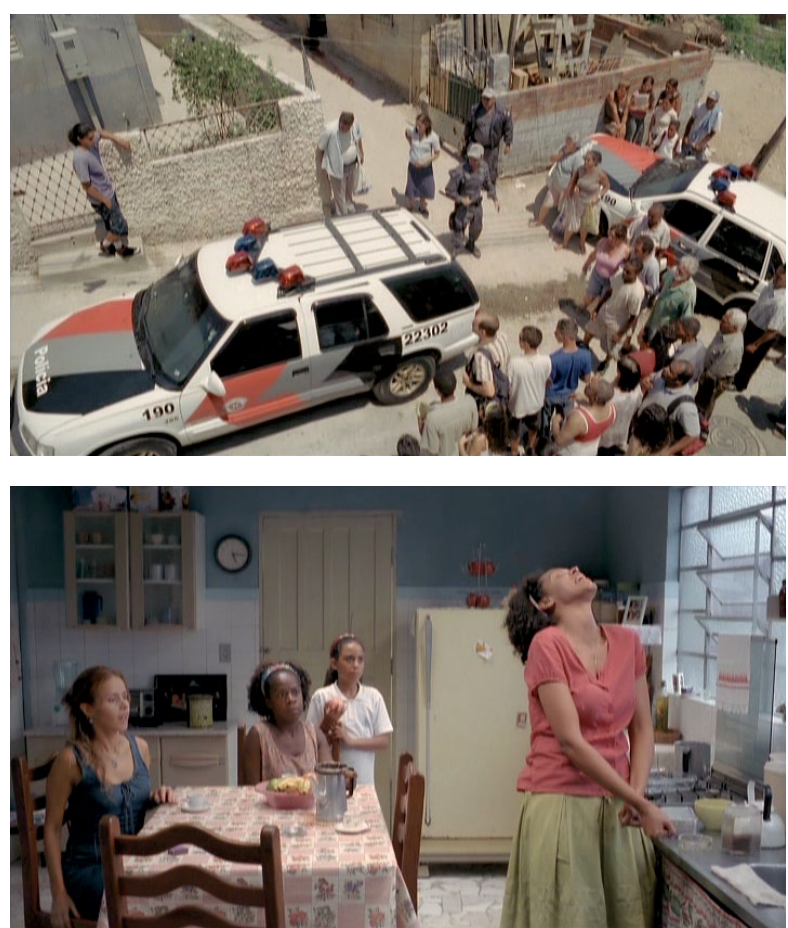

Figura 44 
Seguindo a analogia entre personagens e espectadores (ou receptores, para abranger a mídia de modo amplo) o grito do inquilino à plateia-vizinhança se dirige também à nossa posição diante dos filmes e das notícias sobre violência. Como o olhar do casal que motiva a exibição dos inquilinos, as narrativas e notícias de violência respondem, em grande medida, à curiosidade voyeurista do público pelos episódios de violência. Numa relação que se retroalimenta, o grande interesse dos espectadores por essas notícias, expresso pelos índices de audiência e pelo largo e destacado espaço ocupado por essas notícias, acaba por fomentar a exploração dos eventos pela mídia, para quem crime e violência representam importantes matérias-primas do conteúdo noticioso e que são apropriados de modo comercial (como na disputa por audiência) e político (corroborando com a construção da opinião pública e também convocando atores sociais, políticos e instituições a se posicionarem e agirem $)^{22}$.

Além de se apresentarem como espetáculo, a construção dos inquilinos a partir desse olhar que - apesar de próximo - vem do outro lado do muro e pouco conhece de fato dos sujeitos que observa, remete também à figura genérica do criminoso que, recorrentemente, aparece na mídia. Diferente do que é comum às narrativas mais clássicas, em que tanto heróis quanto violões têm objetivos, com frequência nos media aquele que é citado como responsável pelo crime, como os inquilinos (e como os personagens do livro de Fernanda) não aparece com motivações psicológicas ou sociais, nem com passado ou presente. Sem ponto de vista e sem direito a se expressar, é apresentado como um personagem cruel que, junto de seus crimes, surge como epifenômeno, isto é, brota espontaneamente sem se agregar a nada (a não ser às demais notícias sobre crime e violência que geram um círculo de significados $)^{23}$.

\footnotetext{
${ }^{22}$ RONDELLI, Elizabeth. Media, representações sociais da violência, da criminalidade e ações políticas. Comunicação \& Política, Rio de Janeiro, v.1, n 2, 1995, p. 98.

${ }^{23} \mathrm{Ibid}$., p. 99. Ainda segundo Rondelli, apesar de terem aparência de epifenômenos, os eventos, ao serem narrados pela mídia, criam um circuito de produção de sentidos (RONDELLI, 1998).
} 
Há certa simetria entre a relação de voyeur da família com os inquilinos e com a posição dos personagens em frente da TV. Como outra janela, o televisor parece se tornar menos interessante com a chegada dos inquilinos que trazem as ameaças das notícias à casa ao lado e também quando os perigos anunciados pelas reportagens transmitidas na TV aparecem do lado de cá da tela (como com os ataques a ônibus vistos nos trajetos, e com os assassinatos de Evandro e Dimas). Mesmo perdendo na disputa de interesse dos personagens, a TV, junto às falas, é um importante elemento na produção do espectro da violência e também no desenvolvimento da crítica à mídia e ao modo como nos relacionamos com as narrativas sobre a violência.

O televisor, nosso primeiro contato com o lar e com a família de Valter, tem presença marcante na casa. Posicionado ao lado da porta de entrada, o aparelho é muitas vezes inferido pelo som e pela posição dos personagens sentados no sofá. Se na janela eles se posicionam de costas para a câmera, ao assistirem à TV, por vezes, os personagens aparecem de frente (figuras 45 e 46) como que espelhando nossa postura de espectador.

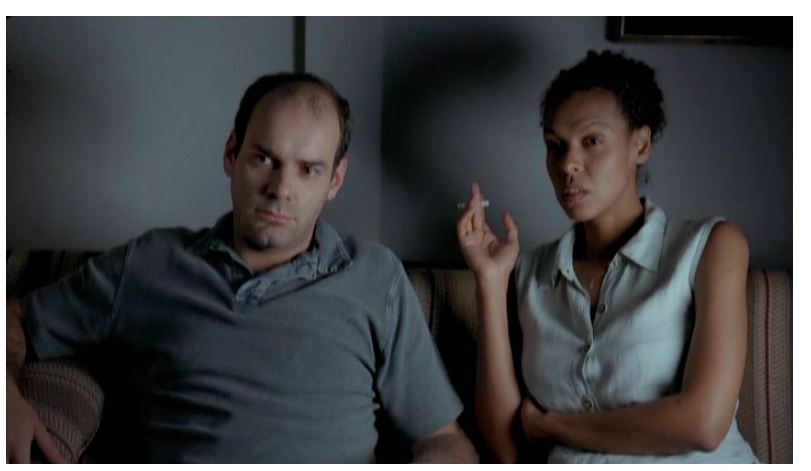

Figura 45

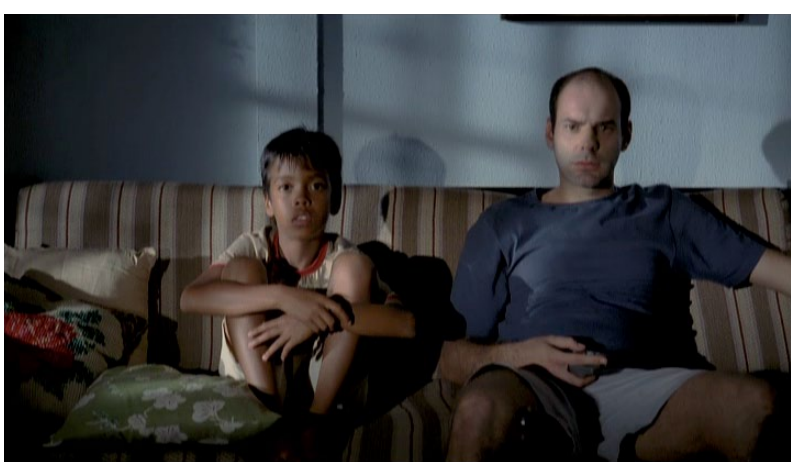

Figura 46

Valter e lara assistem à reportagem de Datena no início do filme e, ao fim, Valter e Diogo assistem à partida de futebol. 
Postados no sofá em frente da TV, os personagens assistem ao jogo de futebol e à novela, mas, na maior parte das vezes, o televisor exibe notícias sobre os ataques do PCC e outros crimes, em narrações recheadas de detalhes escabrosos que, em sua quase totalidade, não são acompanhadas das imagens da reportagem. Um dos poucos momentos em que as imagens transmitidas pelo televisor aparecem para nós será na reportagem de Datena citada no início, que convém detalhar.

Na primeira cena, após a chegada dos inquilinos, Valter fecha as janelas e a porta e se senta ao lado da esposa para assistir à reportagem apresentada por Datena que se inicia: "A polícia encontrou o corpo da menina de oito anos, Maria Elisângela Aparecida que estava sumida há dois dias. Maria Elisângela, de oito anos, vocês ouviram

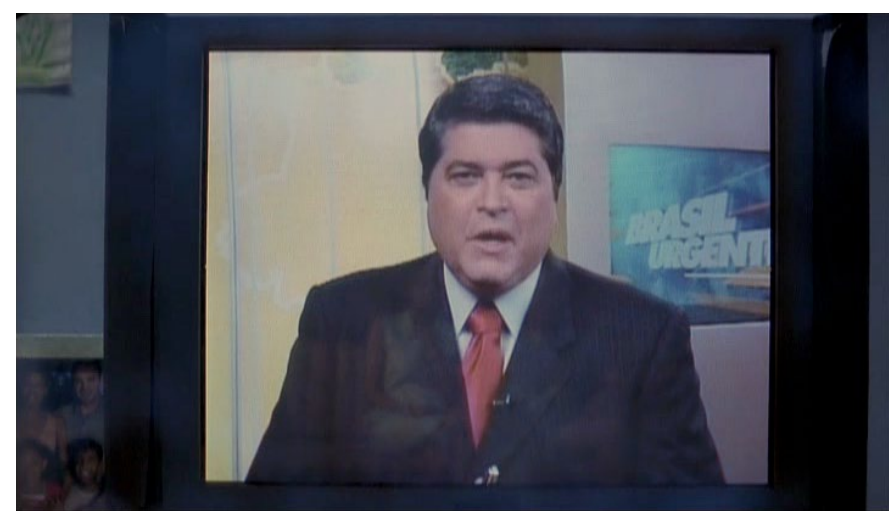

Figura 47
Ao lado do televisor, um discreto retrato exibe a sorridente família. bem, oito anos, foi estuprada por três homens, esfaqueada e estrangulada". No contracampo do casal sentado no sofá, a TV nos mostra Datena, que, endossando o tom sensacionalista da notícia, descreve como o corpo foi encontrado, o nervosismo e desespero da mãe - descrição que redunda no que

é exibido. Conforme o zoom avança rumo à TV, Valter e Iara que, em princípio, são vistos no reflexo da tela, aparecem também na discreta foto de família colocada do lado direito do aparelho, onde, junto aos filhos, sorriem (imagem 47).

A fumaça do cigarro de Iara é lançada sobre o close do rosto da mãe que grita "minha filha" (imagem 48) e Datena continua sua escabrosa narração "a irmã não tem dúvida nenhuma, o corpo encontrado é o da Maria Elisângela. Corpo imaculado, um ser puro, um anjo, conspurcado, roxo, rasgado. Naquele saco ali, pra você ter uma ideia, tem um corpo. O corpo de uma menininha. Não dá pra falar mais nada. Você fica maluco com uma notícia dessas". 
$\mathrm{Na}$ reportagem de

Datena, um close do rosto da mãe que grita.

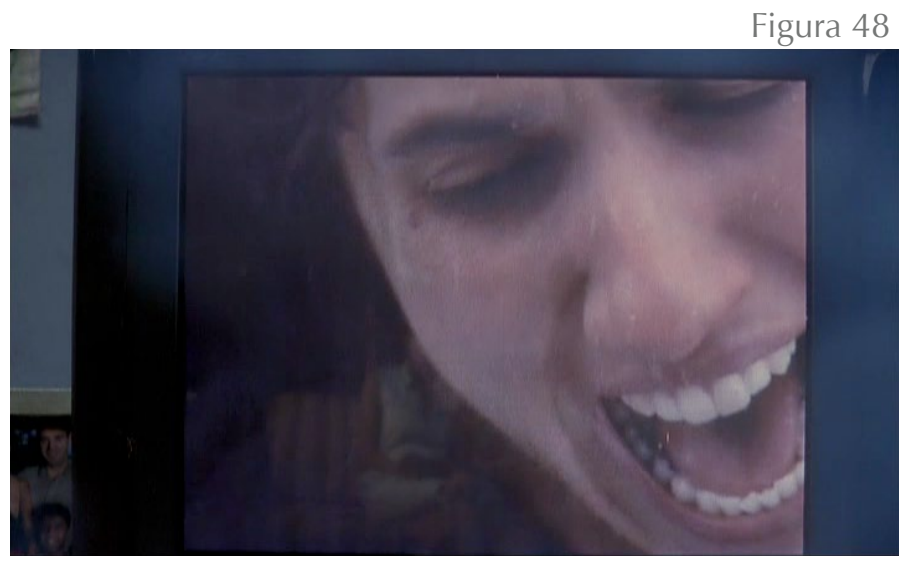

Além do deslocamento produzido pela reportagem inserida dentro do filme que, fora do suporte da TV, produz um forte estranhamento, a foto da sorridente família e o entretido olhar de Iara tencionam com a desgraça da notícia. De modo irônico, sobre o sensacionalismo da matéria (que, com as imagens do sofrimento e com a narração de Datena, busca elevar a dimensão já pavorosa da notícia, produzindo exagero sobre o exagero), é inserido junto aos gritos da mãe o início de Overture-Fantasia (Op. 67a) - composição de Tchaikovsky inspirada na tragédia shakespeariana Hamlet. Além do choque resultante da junção das imagens e sons sensacionalistas do programa da TV com a música clássica, o timbre grave e a melodia dramática da trilha conferem outro significado às imagens, como que devolvendo o sentido dramático à notícia, que fora retirado pelo excesso produzido pelas imagens e pela narração. Os últimos acordes do trecho da ópera fecham a reportagem e soam ainda no quadro seguinte, quando se dissolvem nas graves batidas do rap Tempos difíceis (Racionais $M c$ 's) que os inquilinos ouvem ao chegar e que despertam Valter.

Essa sequência coloca em pauta também o uso da trilha sonora nessa narrativa. Assim como em outros momentos, a trilha clássica - sempre extradiegética - produz comentários sobre a cena (como Un grand sommeil noir e Overture-Fantasia que, respectivamente, comentam sobre a presença indesejada da favela/inquilinos e sobre a tragédia da reportagem). As composições recebem um tratamento que se diferencia do visto em Salve Geral, em que a música tema (Slavonic Dance) é tanto extradiegética quando diegética e que, no plano diegético, surge atrelada a Lúcia - personagem que, assim como 
a melodia, destoa do contexto carcerário. Em oposição à música erudita, a trilha diegética de Inquilinos compreende o crítico rap dos Racionais $M c$ 's que, de modo amorfo, se mistura à Balança bumbum e Muvuca (de Nelson Nascimento, "o rei da pisadinha") e também à Dança da mãozinha (Tchakabum), que aparecem com certo tom pejorativo na narrativa. Se o rap de Inversão soa um tanto artificial pelo deslocamento de sua tradição (ao dar voz à classe média em sua crítica à elite), aqui a contundente canção dos Racionais $M c$ 's não é explorada (sequer ouvimos a letra), mas sim abafada junto aos outros sons da periferia (pagodes, forrós ou "pisadinha" - como as músicas de Nelson Nascimento são classificadas) que surgem de modo incômodo ou cômico.

De volta à reportagem, além do caso do Datena, as demais notícias sobre violência não serão incorporadas às falas e temores dos personagens, que (do sofá ou de outro espaço) dirigem pouca ou nenhuma atenção às reportagens, por mais violentas e impactantes que sejam. Como a novela do início, a narração da notícia sobre perseguição se mistura com os demais sons diegéticos em uma das voltas de Valter da escola (figura 15). Após desviar do carro dos vizinhos, o personagem abre o portão e, na banda sonora, ouvimos "Olha só a situação aqui. Outro tiro, já foi ferido, rapaz já foi ferido e ele continua correndo”. No interior da casa, Iara está sentada no sofá em frente ao televisor, aponta o lápis da filha e sorri quando Valter entra; a narração - que tem gritos ao fundo - continua: "E aí o tiro que matou o rapaz, meu Deus do céu, barbaridade!". Indiferente à reportagem ela desliga a TV e vai à cozinha servir o marido que, após espiar o quintal ao lado, lhe perguntará sobre os inquilinos (figuras 19 a 22). Em outro momento, Diogo dorme no colo da mãe e, ao seu lado, Fernanda brinca no sofá; a narração da reportagem sobre os ataques continua na cena do dia seguinte em que Valter caminha ao lado de um grupo de pessoas para o ponto de ônibus. Os gritos de "Queremos condução" ouvidos no final da reportagem se estende para esta cena e contrastam com as imagens dos trabalhadores andando pacificamente até o ônibus parado no ponto final. 
Como em Salve Geral há aqui uma forte presença da mídia ao longo de toda a narrativa. Mas, diferentemente dos personagens que atuam nos eventos reportados, falam diretamente na TV e são impulsionados à ação pelas notícias, a voz midiática surge em Inquilinos como um ruído que ecoa no cotidiano e que pouco interfere na trajetória dos personagens. Contudo, o recorrente ruído é potente na construção de um dia a dia invadido pela ameaça. Além da reportagem apresentada por Datena (da novela e do futebol), a narração e os sons emanados pelo televisor se dissolvem nos demais sons das diegeses e, como a explosão e os coletivos queimados, não interferem nas ações diárias que vemos se desenvolver na tela. No interior da cena, sem provocar reações, a maioria das notícias aparecem como um som repetitivo que, saturado, se amortece e se banaliza não por serem fúteis em seu conteúdo ou forma, mas pela repetição que não atrai a atenção dos espectadores-personagens mais interessados com a cena ao lado ou com outras ações ${ }^{24}$. "Fora da cena", isto é, aos olhos do espectador, as notícias configuram a atmosfera do filme e produzem um incômodo pela indiferença dos personagens.

Se a maioria das notícias não provoca um impacto dentro da cena e não atraem a atenção dos personagens, através da montagem é construída uma intensa conexão entre notícia e cotidiano que aparecem integrados organicamente. A relação também produz um choque entre conteúdo da notícia e indiferença dos personagens. Além dos sons do televisor que invadem as cenas do dia a dia, o encadeamento das ações faz com que aquilo que a TV exibe, invada e se misture com aquilo que está do outro lado da tela do aparelho, isto é, a rotina da família. A sequência inicial nos apresenta isso com intensidade, passando de uma janela a outra: da briga na novela à briga dos vizinhos narrada por Iara, do olhar pela vidraça da cozinha ao olhar à TV que, após os ataques aos ônibus, exibe a notícia de

\footnotetext{
${ }^{24}$ Sobre o empacotamento e a saturação das imagens televisivas, Jaguaribe diz "a natureza reiterativa desses produtos midiáticos amortece, banaliza e pulveriza a apreciação crítica, porque eles se constituem como discursos pré-ordenados que visam provocar respostas previamente estipuladas." JAGUARIBE, Beatriz. O choque do real: estética, mídia e cultura. Rio de Janeiro: Rocco, 2007, p. 105.
} 
Datena. O estupro narrado por ele é lembrado pelas falas de Iara e se conecta à ameaça pedófila que se insinua e aos inquilinos que, dizem, vieram do local onde o crime aconteceu. Da reportagem aos ataques do PCC, dos tiros da TV às mortes que se concretizam na trajetória de Valter a TV faz parte do ralentar da violência no cotidiano e se mistura às fofocas, as miradas à casa ao lado, aos sonhos e imaginações.

Tencionando com o deleite em assistir ao que se passa na casa ao lado e com as fofocas, as máximas de "não se meter" e de que devidamente em seu lado do muro fica "cada um na sua", são compartilhadas pelos personagens e repetidas em diferentes momentos. Essa lógica é evocada também como razão para o assassinato de Seu Dimas que "foi se meter no que não é dele". O princípio de "não se meter" - que talvez escamoteie a impotência para (re)agir - também se expressa pela não-ação de Valter, personagem que, na narrativa, é quase o avesso do protagonista. Segundo relatos e comentários em blogs e páginas da internet, a não ação de Valter é apontada como aquilo que torna o filme incômodo e desinteressante. O seguinte comentário exemplifica essa opinião: “(...) filme que deixa a desejar em alguns aspectos, não conseguiria falar sobre a fotografia, sobre a edição, direção de atores, pois, assistindo [a] esse filme só consegui perceber falhas do roteiro. Não sei se por eu ter ficado com certa raiva logo no começo do filme do covarde Valter, afetou minha opinião sobre o filme. (...) O roteiro é como Valter, covarde." 25.

Inversamente, considero que a não reação do personagem é um dos elementos que torna o filme extremamente interessante na construção de sua ironia e crítica sobre as narrativas da violência que criam espetáculos no cotidiano. Apesar do desejo de se impor aos vizinhos, motivado por uma razão imaginária (o flerte com a esposa), pelos atritos do convívio ou pela agressão a Seu Dimas, como que em um pragmatismo covarde ${ }^{26}$, Valter

\footnotetext{
${ }^{25}$ Disponível em: <http://cinensaio.blogspot.com.br/2011/03/os-inquilinos-sergio-bianchi.html>. Acesso em: 24 mai. 2014.

${ }^{26}$ XAVIER, Ismail. Corrosão Social, Pragmatismo e Ressentimento. Novos Estudos, São Paulo, v. 76, $2006 a$.
} 
recua e permanece mais como espectador do que como protagonista.

A postura dos personagens remete mais uma vez ao esquema do espetáculo e também às tramas de Hitchcock que lhe fazem referência. Como Scottie (Vertigo) e Jeff (Janela Indiscreta) que ficam paralisados, respectivamente, pela vertigem e pelo gesso, Valter também se encontra relativamente imobilizado por seu pragmatismo. Em Inquilinos, o personagem-espectador que, assim como Jeff e Scottie, mimetiza a teoria do dispositivo do cinema de Jean-Louis Baudry ${ }^{27}$ é divido entre Valter e Iara: a imobilidade dele se soma ao prazer e ao investimento da energia do olhar dela. Assim, juntos, eles completam quase por inteiro o dispositivo descrito por Baudry (que, além da imobilidade, prazer e da energia, compreende também a regressão infantil) ${ }^{28}$.

Após a prisão dos inquilinos veremos a única cena em que Valter ocupa o outro espaço, quebrando a fronteira do espetáculo. Todavia, após o personagem olhar a casa revirada e manchada de sangue de Seu Dimas, a ação de entrar na casa dos inquilinos é interrompida quando Valter percebe que é observado por Iara. Assim, quando tem consciência de estar no espaço da "outra cena", o espetáculo termina e passamos para o habitual café da manhã do dia seguinte.

Essa não-ação que quebra a expectativa que geralmente é depositada no personagem central (e que reaparece em personagens de outros filmes interpretado por Descartes) se junta às demais ironias de Inquilinos. A tentativa do personagem de proteger a família é apresentada com contornos cômicos. Valter faz cara de mal e muque em frente ao espelho enquanto a esposa e o cunhado zombam dele na cozinha. Contra a ameaça e incômodo provocado pelos inquilinos, a grande ação de Valter (além de imitar o cachorro e urinar no quintal) é a pedrada que recebe na cabeça.

\footnotetext{
${ }^{27}$ Jeff e Scottie são colocados "(...) quase como uma ilustração da teoria do dispositivo cinematográfico formulada por Jean-Louis Baudry: imobilidade, investimento da energia do olhar, prazer nessa posição de 'tudo perceber', regressão infantil'. XAVIER, Ismail. O olhar e a cena: melodrama, Hollywood, Cinema Novo, Nelson Rodrigues. São Paulo: Cosac Naify, 2003, p. 73.

${ }^{28}$ Baudry apud XAVIER (2003).
} 


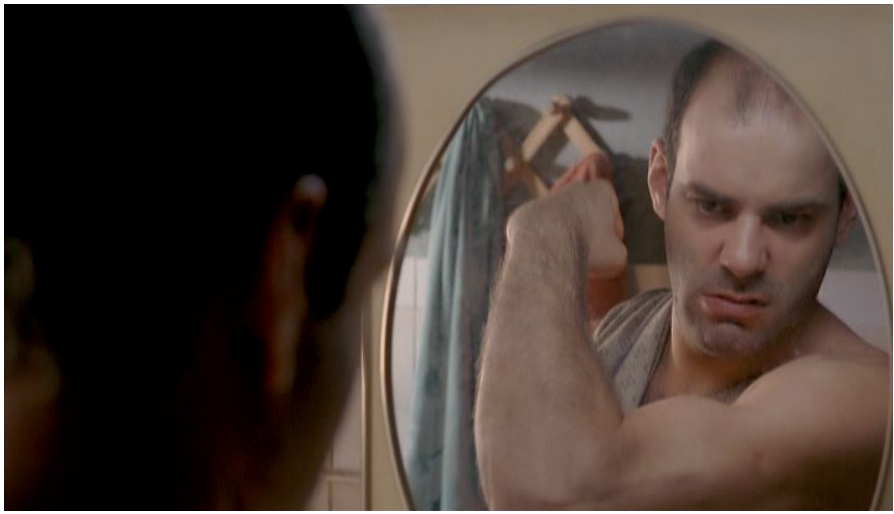

\section{Enquanto lara e 0 irmão the caçoam, Valter faz muque no espelho do banheiro.}

Valter deseja agir "A gente tem que enforcar tudo que 'tá' errado", mas eles são em maior número e a reação só se realiza na imaginação onde ele agride com socos e chutes um inquilino, ação que, com a acidental pedrada, compõe as exclusivas imagens de agressão no filme. Entre a covardia, impotência e preocupação, Valter é pragmático "Eu tenho mulher e filhos", cantarola e, de modo mais enérgico, contém sua reação batendo a própria cabeça contra o guarda-roupa. No filme, as categorias são rígidas e respeitadas por Valter, o que talvez lhe impeça de entrar no circuito do ressentimento. Ser trabalhador e estar no interior da família nuclear (que aparece em Salve Geral, mas que é bastante ausente nos filmes que abordam a violência urbana nas últimas décadas) são os elementos que lhe convidam a não reagir e também a aceitar sua não-ação. Após pedir uma arma ao amigo Francisco, Valter rapidamente se conforma com a resposta: Francisco não tem arma e, como ele, é trabalhador: "A 'cara' deles é ser bandido, a nossa é trabalhar", "ficar quieto, ficar calado", enfim, não devem se meter com criminosos ou com seu mundo.

Como na pesquisa realizada em Cidade de Deus pela antropóloga Alba Zaluar - que pode ser pensada como embrião do livro e do filme que levam o nome da localidade, "pegar em arma de fogo" (ou "revoltar") representa a linha que divide trabalhadores e bandidos. Ao fazer uso da arma de fogo o indivíduo se insere dentro de um ciclo de vingança, ou “condomínio do diabo" que podemos pensar como algo análogo ao ressentimento presente 
nos títulos da Retomada ${ }^{29}$. Valter se esquiva do círculo de vingança ao aceitar permanecer do outro lado, como trabalhador, provedor de sua família, o que também significa não reagir, já que, na narrativa, a arma é a possibilidade de ação do colega que mata o traficante que ameaçara dormir com a esposa e, conforme nos diz Valter, sua ausência configura a impossibilidade do cunhado intervir.

Assim como os demais personagens Valter também é um espectador; um pouco menos interessado e um tanto sufocado pelo fascínio dos outros e também pelo espectro da violência que lhe acompanha. Sua não reação é ratificada com a cena final quando assiste à chegada dos novos inquilinos e segue pela mesma rua, reiterando a circularidade em que não há horizonte para mudanças, recolocando assim o pessimismo e a amargura da filmografia de Bianchi.

A paralisia de Valter remete às produções do pós-guerra e à imagem-tempo deleuziana. Diferente de Salve Geral que, seguindo o esquema da imagem-ação (no qual os personagens reagem às situações), Inquilinos se aproxima das características da imagemtempo. Como nos filmes do pós-guerra, em Inquilinos as situações sensório-motoras (ação/ reação) são “(...) substituídas por personagens que erram sem reagir ao que lhes acontece. O passeio, a perambulação, a errância fazem com que os personagens estejam em um contínuo ir e vir destacado da estrutura de uma ação"30. As situações cotidianas do filme se esquivam das forças da imagem-ação: as situações banais e ordinárias seguem um curso para o qual o personagem não tem resposta ou reação, cuja "(...) ação flutua na situação, mais do que a arremata ou encerra" ${ }^{31}$.

\footnotetext{
${ }^{29}$ ZALUAR, Alba Trabalhadores e bandidos: identidade e discriminação. In: A máquina e a revolta: as organizações populares e o significado da pobreza. São Paulo: Brasiliense, 2000, p. 136-146. A pesquisa pode ser pensada como um embrião de Cidade de Deus - livro (Paulo Lins) e filme (Fernando Meirelles); nesse capítulo, personagens que ficaram internacionalmente conhecidos - como Mané Galinha e Zé Pequeno - são evocados.

${ }^{30}$ MACHADO, Roberto. Deleuze e a crise do cinema clássico. In: PESSOA, Fernando; BARBOSA, Ronaldo. Do abismo às montanhas. Vitória: Fundação Vale, 2010, p. 205.
}

${ }^{31}$ DELEUZE, Gilles. Para além da imagem-movimento. In: Cinema 2: A imagem-tempo. São 
Além da proximidade com o esquema de Hitchcock por incluir o espectador no filme $e^{32}$ (esquema que será levado às últimas consequências no neorrealismo e na nouvelle vague francesa), a contemplação do personagem e seu constante vagar remetem aos personagens do "cinema de vidente":

$\mathrm{Na}$ imagem-ação (...) os personagens reagiam às situações; mesmo quando uma delas se encontrava reduzida à impotência (...). O que o espectador percebia era, pois, uma imagem sensório-motora da qual participava mais ou menos, por identificação com as personagens. Hitchcock inaugurou a reversão deste ponto de vista, incluindo o espectador no filme. (...) a personagem tornou-se uma espécie de espectador. Por mais que se mexa, corra, agite, a situação em que está extravasa, de todos os lados, suas capacidades motoras, e lhe faz ver e ouvir o que não é mais passível, em princípio, de uma resposta ou ação. Ele registra, mais que reage. Está entregue a uma visão, perseguido por ela ou perseguindo-a, mais que engajado numa ação. (DELEUZE, 1990, p. 11).

Essa proximidade com a imagem-tempo pode ser pensada também com relação à ausência de imagens literais da violência que fazem emergir uma situação incômoda, sufocante, que - no paralelo com Deleuze - podemos pensar como o "insuportável" definido pelo autor.

Paulo: Brasiliense, 1990, p. 13.

${ }^{32}$ DELEUZE, Gilles. Cinema 1: a imagem-movimento. São Paulo: Brasiliense, 1985, p. 211. 


\section{Specto}

O verbo latino specto forma dois conceitos chaves de Inquilinos: espectador (spectator) e o espectro (spectrum). Em sua construção do cotidiano, Inquilinos aborda com contundência a violência não apenas através do fenômeno físico, que incide diretamente sobre os corpos, mata e fere, mas em especial por meio das falas, boatos, fofocas e desejos que têm enorme importância no próprio fenômeno. As diversas janelas (do muro, da casa e a TV) e a postura de espectador dos personagens produz ainda uma interessante crítica sobre as narrativas da violência e sobre a forma como nos relacionamos com elas.

Se em Vertigo e em Janela Indiscreta o comentário é acerca do dispositivo cinematográfico, em Inquilinos, o comentário se dirige a um quadro mais amplo, que envolve o cinema e também as diversas outras narrativas sobre a violência - conjunto que, no filme, aparece como o espectro da violência. Como em Salve Geral as narrativas da TV também são parte constitutiva de Inquilinos, mas, diferente de uma relação mimética, aqui as reportagens são retrabalhadas com ironia e compõem esse espectro que (per)segue Valter. Simetricamente aos olhares para o outro lado do muro o telejornal, com sangrentas e nefastas notícias, as fofocas, especulações, sonhos e delírios - que esvanecem e se confirmam -, formam esse espectro, essa massa que traz à tona a violência. Ao abolir as imagens literais da violência, além de colocar em posição central as narrativas da violência, Inquilinos constrói uma crítica que se volta sobre si, filme que está dentro desse conjunto de narrativas.

Aqui, o sensacional não impera sobre, tampouco interrompe o cotidiano, mas faz parte do dia a dia. Sem ritmo frenético, montagem fragmentada ou câmera na mão - que marcam títulos de maior repercussão que abordam a violência nacional e que, de forma menos intensa, constroem também as imagens da São Paulo que não dorme (presente em telejornais, propagandas e em diferentes graus em Inversão e Salve Geral) e, mesmo 
sem trazer a violência de forma gráfica, com imagens literais, Inquilinos constrói sobre as diversas frestas do cotidiano uma poderosa sombra da violência que se insinua, imagina, especula, mas que também se confirma.

Nem a violência revolucionária de Glauber, nem a da guerra ao tráfico; apesar de incomodado, contrariando o que sugere o subtítulo, Valter não muda nem de comportamento nem de residência; assim como a indiferença às notícias, Valter, na tônica do "não se meter", permanece paralisado, relativamente alheio à conjuntura que lhe cerca. Das notícias que não têm sua atenção, ao cenário de coletivos em chamas e ao assassinato na casa ao lado, ele aceita, convive com situações agudas e, quando não aparece indiferente, sua ação se paralisa pelo pragmatismo "Eu tenho mulher e filhos" - para desespero de muitos espectadores do filme. Os sons, falas e práticas violentas, ao se tornarem ruídos cotidianos na diegese, incomodam e produzem estranhamento pela constância e pela não reação do não-protagonista.

De maneira distinta dos dois primeiros longas abordados nesta dissertação, os personagens de Inquilinos não atuam sobre as notícias ou sobre as ações noticiadas (sequestro, ataques). Mesmo sem atuarem sobre as notícias, os personagens de Inquilinos são ativos na produção das narrativas da violência. As constantes falas, olhares, especulações e imaginação de Valter, misturados com as narrações da TV acionadas na montagem, constituem o espectro que, por fim, se volta contra o personagem e lhe sufoca.

Longe das ações violentas construídas em Salve Geral e Inversão, que surgem de modo mais ou menos explícito na tela e afetam a trajetória dos personagens e sobre ela se impõem, em Inquilinos o cotidiano é potente, ou melhor, é conformado, já está moldado pelo espectro que se instaura como parte da rotina que não se altera. Entre ações corriqueiras, a violência sem imagem literal e na forma de espectro se torna sufocante, produz um comentário bastante contundente e traz à tona algo semelhante ao que Deleuze chamou de "intolerável". Como comentado anteriormente, se Salve Geral pode ser pensado na chave 
da imagem-ação e Inversão contém alguns aspectos que lembram a imagem-pulsão (como "mundo originário" e os personagens "bichos-humanos"), Inquilinos flerta com algumas características que estão ligadas ao surgimento da imagem-tempo.

A perambulação, a banalidade cotidiana e a não-ação do personagem em meio a situações que não se prolongam em ações podem ser pensadas como elementos que conectam Inquilinos aos filmes do pós-guerra elogiados por Deleuze. A ausência das imagens literais da violência, em oposição à sua constante presença em outros filmes, remete também ao contexto saturado de imagens no qual se deu (entre diversos outros fatores políticos, sociais e econômicos) a crise da imagem-ação. Em Inquilinos é justamente através da ausência de imagens literais da violência que surge com potência o espectro (ausência que, como vimos, não faz do filme uma narrativa "branda").

Diferente da narrativa de Salve Geral em que o esquema sensório-motor torna suportável e tolerável qualquer situação ao inseri-la em um sistema de ações e reações ${ }^{33}$, Inquilinos parece se aproximar da nova imagem (ótica e sonora pura) que ao não se prolongar em ação:

(...) deve permitir apreender algo intolerável, insuportável. Não uma brutalidade como agressão nervosa, uma violência aumentada que sempre pode ser extraída das relações sensório-motoras na imagem-ação. (...) Trata-se de algo poderoso demais, ou injusto demais, mas às vezes também belo demais, e que portanto excede nossas capacidades sensório-motoras. (DELEUZE, 1990, p. 28-29).

Ao se libertar da ação-reação, indo além dos clichês que impedem o espectador de ver o que há de insuportável e inaceitável, a nova imagem revela “(...) que nossas relações habituais com o mundo são convenções para fazê-lo tolerável, e nos tornar obedientes,

33 DELEUZE, Gilles. Para além da imagem-movimento. São Paulo: Brasiliense, 1990, p. 30. 
conformados, revela o que não se vê, o imperceptível" ${ }^{34}$. Nesse paralelo, Inquilinos rompe com a inércia habitual e com o esquema que tornaria tolerável a violência que rodeia Valter. A não (re)ação de Valter, associada à ausência da imagem-violência, cria um clima sufocante que remete ao intolerável. É justamente a partir da ausência da imagem-violência e do cotidiano onde o esquema sensório-motor é fraco que desponta o dia a dia saturado pelo espectro - contexto que pode parecer exagerado no filme, mas que não é tão estranho ao cotidiano do lado de cá da tela, igualmente invadido por fofocas, reportagens e imaginações nas quais participamos, mais ou menos, ativamente.

Inquilinos tece também um interessante comentário sobre o registro do bem versus mal e do estigma arquitetados pelas narrativas. De modo distinto ao de títulos anteriores dirigidos por Bianchi (como Mato Eles? - 1983 e Cronicamente Inviável - 2010), Inquilinos faznos refletir sobre o espectro e sobre os espectadores, propondo questões que não responde, mas que ensejam reflexões sobre nossos dias.

Com a força das janelas, Inquilinos é irônico com a posição do espectador-produtor das narrativas e do espectro sufocante. Nesse caso, o espectador não é passivo receptor, mas produtor ativo que, além de gerar e reproduzir as narrativas (boatos, relatos etc.), é a sua existência como parte do público que "quer ver o coro comer" que fomenta os massivos discursos sobre violência. Assim, o fascínio nas falas e olhares adquire contornos patológicos ao se tornar excessivas em especial ao final do filme, quando por todos os lados se espalham comentários sobre o assassinato que não poupam detalhes atrozes. As descrições se chocam com a ausência das imagens que exibam o que é narrado e adquirem um sentido peculiar por não estarem no esquema da ação-reação que poderia lhes justificar.

Esse outro (os inquilinos e o espaço da favela) que, apesar de próximo, pouco conhecemos - que se mistura à massa da violência, provoca medo e fascínio - remete também à operação geral da mídia que, não raro, pouco investiga e apenas classifica o

\footnotetext{
${ }^{34}$ MACHADO, Roberto. Deleuze e a crise do cinema clássico. Vitória: Fundação Vale, 2010, p. 207.
} 
mundo dicotomicamente entre bons e maus, seguindo um divisão previamente estabelecida.

Como a fala do crime e os diversos discursos sobre a violência, os filmes também são narrativas que conferem sentido ao universo abalado pela violência. Ao inserir esses outros discursos que também lidam com a violência e ao discutir, com ironia, como os personagens (que remetem aos espectadores) constroem e se relacionam com esses discursos, o filme, além de sugerir uma crítica sobre o espectro, aponta para as implicações de sua própria confecção. Apesar de menos agressivo e direto, Inquilinos mantém a tônica da filmografia de Bianchi: a crítica ao fascínio do voyeur que beira o doentio é dirigida aos espectadores e também aos produtores (categoria do qual Bianchi faz parte) desses discursos e narrativas que, na outra ponta, respondem ao desejo de "ver o coro comer".

Sem a intenção de avaliar "o modo adequado" de como se tratar da violência, a opção de Inquilinos de não inserir a violência em imagens é singular e bastante interessante. Ao inserir uma cena (personagens-espectadores) dentro da cena que assistimos, Inquilinos espelha nossa posição de espectador, produzindo uma crítica à nossa postura que, de maneira similar a das personagens, ao mesmo tempo em que tememos a violência, também a consumimos, produzimos e reproduzimos suas narrativas. 


\section{Considerações finais}

Após a análise dos três filmes, retomo as questões centrais desta pesquisa: como a cidade de São Paulo sob ataques do PCC realizados em maio de 2006 é construída em cada um dos títulos? Como o crime e a violência urbana são esboçados? De que forma os personagens citadinos de cada filme se relacionam com esse quadro? Como vimos, em sintonia com a "tradicional poliformia paulistana", cada um dos longas responde às questões de uma forma específica. $\mathrm{Na}$ análise fica claro que mais do que tramas centradas em diferentes nichos (classe média, poder público, PCC; empresários, capangas e polícia; família de classe popular), as diferenças entre os filmes são intensamente marcadas pelas combinações dos elementos formais articulados em cada longa. Para além dos cenários específicos onde as tramas se desenvolvem, audiovisualmente Salve Geral, Inversão e Inquilinos constroem diferentes cidades na tela. Desse modo, os sons, imagens e suas articulação através da montagem são potentes na construção de cada uma das cidades fílmicas.

Em Salve Geral, fora das cenas de ação, a decupagem clássica mantém enquadramentos estáveis que exibem espaços genéricos, locais emblemáticos e paisagens que se assemelham às características da capital paulista (como as longas malhas viárias, o bairro periférico de classe média baixa e a periferia pobre). A multiplicidade de paisagens forma uma cidade longa e plural. A marcante extensão urbana é construída e reforçada pelos planos aéreos das malhas viárias, pela montagem que salta de um espaço ao outro e pelas constantes cenas de Lúcia e Rafa em trânsito por rodovias, ruas e avenidas. Como foi comentado, o trânsito mimetiza o movimento da narrativa: primeiro para baixo e para os lados (para 
o periférico e ficcional "Jardim Copacabana”). Após os inúmeros deslocamentos entre presídios, delegacias, locais emblemáticos e genéricos, ocorre o deslocamento final, quando se afastam do ambiente consumido pelos ataques e da desmedida reação da polícia que se anuncia.

Apesar do constante deslocamento e da intensa presença da cidade na narrativa, a São Paulo do filme não tem outro papel além de ser o cenário dos ataques e o palco onde as ações se desenvolvem. De modo semelhante à problemática ligada à população carcerária e aos ataques que se encerram no drama familiar e no espetáculo do filme de ação, o contato com a cidade também é relativamente pontual: a narrativa não penetra na cidade, não vai além da superfície das vias percorridas pelos personagens, dos espaços onde se dão os ataques e das celas onde surgem amores e conflitos. Esse posicionamento que permanece na superfície é de certa forma semelhante à cobertura midiática distanciada na qual o filme se poia para reconstruir o evento. Como vimos, o longa coloca de lado o distanciamento quando penetramos com as cenas de ação nos embates entre polícia e PCC. Todavia, em nenhuma das posições a problemática do conflito, do cárcere e da segurança pública vai além das fervilhantes explosões, troca de tiros, perseguições e do drama que toca Lúcia e Rafa.

A banda sonora de Salve Geral reforça também a separação entre trama e meio abordado. A música-tema (Dança Eslava de Antonín Dvorák) aponta para a distância entre o ponto de vista dos realizadores e o dos detentos/membros do PCC (distância que não é problematizada ou destacada na narrativa). A canção se conecta com os movimentos harmônicos da decupagem clássica e com Lúcia - personagem que "justifica" a canção como som diegético, mas se distancia do universo onde a narrativa penetra. Se a escolha da canção (e da personagem) pode apontar a intenção de aproximar universos distantes, o da professora de piano em decadência e o dos encarcerados, a aproximação não é plena, pois o contato é envolto pelos códigos associados ao universo de Lúcia e aos do cinema 
clássico.

A impecável sonoplastia - com ruídos correspondentes aos detalhes sonoros das ações e a trilha original musicalmente associada ao universo cinematográfico dos soundtracks - se sobrepõem aos ruídos e à poluição sonora da cidade. Assim, tanto pela trilha clássica quanto pelas composições elaboradas para o filme, os sons reforçam a conexão com a estrutura do drama e do filme de ação e sua proximidade com o universo dos realizadores que, como declara Rezende (ver capítulo 1), não tiveram contato com criminosos para a produção do filme.

O ponto de vista distanciado do longa também é endossado pela escolha da personagem central. Mesmo com a descoberta de Rezende sobre as personagens femininas no universo do crime, mencionada na introdução, o diretor opta por centrar a narrativa em Lúcia, figura que vem de fora e que opera como uma guia que, próxima da posição do realizador e do público, nos conduz ao universo desse "outro".

De modo distinto, Inversão submerge na cidade oblíqua, soturna e áspera construída em especial pelos enquadramentos, pela iluminação e pelas relações que abriga. Alguns planos de locais emblemáticos também identificam a paisagem paulistana (como o viaduto sobre a Avenida 9 de Julho e Avenida 23 de Maio), mas o que predomina no longa são os enquadramentos recortados que constroem uma cidade distorcida e amarelada. As características da cidade, que se espelha na mata (metáfora nada sutil para a "selvageria" urbana) se estendem para os personagens que, como a paisagem urbana, são feios, sujos e maus.

Através da miscelânea de estilos, ao mesmo tempo que Inversão lança "lugares comuns" de gêneros audiovisuais e bordões sobre a cidade e sobre personagens masculinos e femininos, o filme desenvolve também interessante comentário sobre o urbano e seus habitantes. Inversão parece manter apenas os traços mais agudos da capital paulista. Ao extremar as características da cidade e dos personagens que sem meio tons se apresentam 
apenas agressivos, interesseiros e maus, o longa constrói uma espécie de arquétipo dessa cidade-selva regida pela disputa capitalista onde só há espaço para a competição que é levada pela narrativa às últimas consequências.

Com espaços que parecem se repetir, os deslocamentos constantes dos personagens não criam uma cidade extensa, mas constroem o senso de uma andança febril. $O$ desesperançoso movimento dos personagens e a trama que se fecha sobre si (pois majoritariamente a trajetória de todos e suas lembranças se encerram na duração da narrativa) formam um círculo onde não há saídas para aqueles que não se inserem no jogo da ilegalidade e da traição. Sem se destacarem na narrativa, os ataques surgem apenas através da fala do narrador e das cartelas. Em meio à trama do filme, os ataques ajudam a construir o áspero cenário urbano no qual ações do PCC, corrupção policial e competição extremada da elite se integram.

Como em Salve Geral, a trilha sonora de Inversão foi composta para o filme, mas aqui as canções não se aproximam de uma tradição cinematográfica e se afastam do modelo clássico para dar destaque à gêneros urbanos (como o rap e o trip hop). As músicas se misturam e ajudam a construir os ruídos da cidade (como a sirene de "Feio, Sujo, Mal" composição de Diogo Poças e Zé Nigro - que nos apresenta os policiais). Na sonoplastia, em vez de buscar construir como Salve Geral uma sonoridade "naturalista", isto é, uma paisagem sonora com sons que se assemelhem àquilo que (supostamente) ouviríamos na situação da cena, a manipulação do som em Inversão é muitas vezes assumida (por exemplo o som metálico que acompanha o "efeito destaque" comentado no capítulo 2). Assim, como nas composições que pela letra e pelos ruídos explicitam sua função tributária da narrativa (em especial o rap "Inversão", que carrega também certo "apelo do real" almejado pela narrativa), as sonoridades assumem de modo mais explícito e textual o ponto de vista declarado pelo diretor que, longe da posição de "não julgar", que Salve Geral parece buscar, aqui é explicitada. 
Diferente da pluralidade de cenários e regiões dos dois primeiros longas, a São Paulo de Inquilinos é composta pelo local de trabalho e de estudo de Valter e pelo bairro periférico onde ele reside com a família. O bairro é o espaço onde se dá a maior parte das cenas e o local onde o filme se inicia e termina. Em Inquilinos, a imensidão paulistana não é construída pelo deslocamento dos personagens, mas por sua sugestão através de elipses. Assim, "saltamos" da caminhada ao ponto de ônibus no bairro pela manhã para a noite quando Valter desce no ponto final da linha Pinheiros-Valo Velho; da saída de casa de manhã para seu retorno ao bairro de noite. Sem planos emblemáticos que caracterizem a cidade, o constante ir e vir de Valter pode ser pensado como uma das marcas que confere identidade à cidade de São Paulo de Inquilinos.

O cotidiano que, a despeito dos conflitos, impera no filme é construído tanto pelas ações que estruturam a narrativa quanto pelos enquadramentos que se assemelham e ajudam a criar a repetição do dia a dia. Além disso, os sons que invadem as cenas são fundamentais na construção dessa rotina intensamente ligada ao bairro. Sem composições originais para o longa, a trilha sonora de Inquilinos compreende músicas clássicas extradiegéticas e canções populares que soam na diegese do filme. O pagode, o axé, a "pisadinha", o funk (estadunidense) e o rap, que aqui é abafado, formam as trilhas do dia a dia da vizinhança. As sonoridades populares surgem com contornos cômicos e sentido pejorativo e, na maioria das vezes, perturbam Valter e sua família. No campo sonoro, sem personagem que justifique as músicas eruditas, as composições clássicas assumem a distância do realizador com relação ao universo que aborda. Apesar da discrepância entre os estilos musicais diegético e extradiegético, os comentários produzidos pelas trilhas sugerem a proximidade entre os dramas das cenas e os das canções, como "o longo sono negro" representado pela favela e pelos inquilinos, Piano Quintet que endossa a tristeza com a morte de Dimas e Overture-Fantasia que devolve o aspecto trágico à reportagem sensacionalista apresentada por Datena. Nessa reportagem que aparece no início da narrativa fica claro que as trilhas 
clássica não se impõem sobre, mas se misturam aos sons da localidade: as vozes da notícia se misturam com a composição de Tchaikovsky que por sua vez se conecta com as graves batidas do rap Tempos difíceis (Racionais) que despertam Valter.

Dos três títulos, Inquilinos é o que mais se abre aos sons cotidianos e incorpora nas cenas vozes e ruídos da vizinhança que não estão em quadro e que não se relacionam com as ações dos personagens, como burburinhos de conversas, o vento sobre os arbustos, sons de galinhas, cachorros, batida no prego, o estouro de fogos de artifício e o característico ruído do avião que pelo ar corta a cidade. Os sons do bairro se misturam aos das cenas e com as trilhas extradiegéticas que junto constroem a paisagem sonora do longa. Os diferentes sons que ouvimos nas cenas que se passam nas casas de Salve Geral e Inquilinos - títulos onde os lares dos personagens têm destaque - em parte refletem a escolha de se filmar em estúdio e em locação. Desse modo, a escolha não se encerra no cenário visto em tela, mas se estende às sonoridades que constroem os ambientes (vale lembrar que a casa de Inquilinos foi realmente erguida na Brasilândia pela equipe do filme).

Além da importância na construção do cotidiano da periferia urbana, a banda sonora é fundamental na elaboração do suspense que vem da casa ao lado e também na produção da crítica à espetacularidade presentes em Inquilinos. Como em Salve Geral, as notícias da TV são incorporadas com força na diegese do filme, mas em vez de uma posição mimética, no longa dirigido por Bianchi as reportagens são retrabalhadas com certa dose de ironia. A indiferença dos personagens às escabrosas reportagens que ouvimos e a mixagem que muitas vezes não busca representar a aproximação ou distanciamento em relação a fonte sonora (isto é, a TV) e que lança a narração em situações que contrastam com a notícia, confere um sentido crítico à incorporação das reportagens. Em frente ao televisor ou em outros ambientes, via de regra, os personagens não se abalam com as notícias que, como os ataques que são vistos na paisagem do filme, não interrompem as ações diárias. A despeito da indiferença de Valter e Iara, as notícias se misturam com as fofocas, especulações, 
imaginações e pesadelos formando o espectro da violência que persegue os personagens e se torna sufocante.

Contraposta à constância das reportagens, imaginações e diálogos que abordam a violência, a ausência da imagem literal da agressão junto da não reação dos personagens ajuda a tornar o espectro potente e a construir a crítica sobre as narrativas da violência e sobre o espetáculo que se monta em torno delas. No bairro onde está concentrado o núcleo dramático do filme, os sons, olhares e enquadramentos revelam que, sob a aparente harmonia da vizinhança, há um conflito latente. Ao mesmo tempo em que a tensão com o entorno (a favela e os vizinhos jovens) atemoriza a família de Valter, também a fascina. Através das falas, ruídos, olhares e enquadramentos, Inquilinos constrói uma cena dentro da cena: a cena da casa ao lado que, simetricamente, mas de modo mais potente que a da TV, atrai os personagens.

Ao inserir os personagens assistindo a essa outra cena, Inquilinos coloca em pauta a elaboração das narrativas sobre a violência que além das falas do crime ${ }^{1}$ compreende as produções dos media e também do cinema. Nesse ambiente sufocado pelo espectro da violência, Inquilinos lança assim seu ácido comentário sobre essas narrativas responsáveis pelo nosso contato diário com crime, as quais ajudam a constituir o próprio fenômeno da violência. Inserido no conjunto dessas narrativas, o comentário do filme se dirige tanto aos realizadores quanto a nós espectadores espelhados na posição dos personagens.

Associados às diferentes opções estéticas e narrativas, os três filmes ilustram uma gama de tramas inspiradas pelos ataques de maio de 2006. Os filmes analisados reafirmam alguns aspectos que marcam diferenças entre títulos paulistanos e cariocas das últimas décadas que abordam crime e violência. Além do trânsito por diferentes espaços da cidade, as diversas classes sociais e o protagonismo das personagens femininas aproximam os três

\footnotetext{
${ }^{1}$ Sobre a "fala do crime" ver: CALDEIRA, Teresa Pires do Rio. Cidade de Muros: crime, segregação e cidadania em São Paulo. São Paulo: Editora 34, 2000.
} 
títulos analisados nesta dissertação das características que marcam a filmografia paulistana recente, mencionadas na introdução.

A abordagem do evento que reverberou intensamente na mídia pode sugerir a intenção dos realizadores de embarcar na visibilidade dos ataques, porém, o hipotético desejo não se consuma (as produções pouco repercutiram) e as narrativas apontam para possibilidades que escapam de um apelo sensacional do evento. Com relação ao apelo do evento, o contraste entre a construção e desconstrução do espetáculo é intenso na comparação entre Salve Geral e Inquilinos. No primeiro longa, os personagens atuam sobre as notícias, são protagonistas dos ataques e de outras ações que vemos através da montagem fervilhante e das distanciadas notícias. No último filme, os personagens estão paralisados e observam o que se passa ao lado da casa e na TV, são personagens-espectadores que assistem, entre outras coisas, ao Datena que é re-produzido pelo Delegado Raul em Salve Geral. Dessa forma, ao passo que Salve Geral constrói o espetáculo a partir do embate entre PCC e as forças de segurança pública e carcerária, Inquilinos expõe com ironia o esquema desse espetáculo e aborda também um aspecto que escapa da espetacularidade: a impotência e o desamparo da família que vive ao lado dos criminosos. Já Inversão põe de lado tanto espetáculo quanto ironia: junto aos personagens que se entredevoram, os ataques ajudam a formar as deteriorações urbanas.

No conjunto dos filmes analisados nesta pesquisa se destaca a pluralidade de narrativas que os ataques ensejaram, multiplicidade que passa também pelas formas como os títulos constroem as ações violentas. O primeiro filme reconstrói o evento como espetáculo e os embates com imagens literais; o segundo insere os ataques como pano de fundo na caracterização da cidade turva, onde as agressões expressam tormentos subjetivos ou o grotesco da ação; o terceiro mistura os ataques à massa de ameaças que eclodem e ressoam no cotidiano. As diferentes construções realizadas pelos títulos analisados contribuem com a reflexão sobre as possibilidades de se discutir e abordar temas candentes e também sobre 
as interpretações audiovisuais sobre o polêmico evento.

Os filmes analisados nesta dissertação são reverberações de um evento espetacular, uns mais, outros menos, contribuem para desarticular a lógica que encobre nexos, ou desconexos laços sociais. Com base em uma bem acabada narrativa de ação, Salve Geral oferece um olhar didático sobre as formas de organização da fação criminosa, dos poderes paralelos ligados ao "crime negócio" que se estabelecem em diversos pontos do globo. Inversão passa ao largo, reduzindo os eventos de maio a pano de fundo da trama sua trajetória sufocante, aprisionada, sintomático de uma certa deriva social. Inquilinos se lança sobre as diferenças de posicionamento nos bairros periféricos cindidos em torno de narrativas e expectativas espetaculares e, com isso, chega mais perto de desarticular convenções fílmicas que reproduzem o espetáculo. 


\section{Referência Bibliográfica}

BAZIN, André. A evolução da linguagem cinematográfica. In: O cinema: ensaios.

São Paulo: Brasiliense, 1991.

BENTES, Ivana. Estéticas da Violência no Cinema. Interseções: Revista de Estudos interdisciplinares, Rio de Janeiro, ano 5, 2003. Edição especial.

BERNARDET, Jean Claude. O homem na rua: cinema. Cadernos de História de São Paulo, São Paulo, nº 1, 1993.

BIONDI, Karina. Junto e Misturado: uma etnografia do PCC. São Paulo: Editora Terceiro Nome, 2010.

BIONDI, K.; FELTRAN, G. S.; DIAS, C.C.N.; MANSO, B. P.; MARQUES, A. Um debate sobre o PCC: Entrevista com Camila Dias, Gabriel Feltran, Adalton Marques e Karina Biondi. Revista de Antropologia Social dos Alunos do PPGAS-UFSCAR, São Carlos, 2009.

BORDWELL, David. Aesthetics in Action - Kung-fu, Gunplay, and Cinematic Expression. In: Poetics of Cinema. Nova Iorque: Routledge, 2008.

Narration in the fiction film. Londres: Methuen, 1985.

BURCH, Noel. Práxis do Cinema. Lisboa: Editora Estampa, 1973.

CALDEIRA, Teresa Pires do Rio. Cidade de Muros: crime, segregação e cidadania em São Paulo. São Paulo: Editora 34, 2000. 
City and Disasters, Barcelona, 2004.

CHAUÍ, Marilena. Simulacro e poder: uma análise da mídia. São Paulo: Perseu Abramo, 2006.

CRARY, Jonathan. Técnicas do observador: visão e modernidade no século XIX. Rio de Janeiro: Contraponto, 2012.

DANTAS, Luiz Augusto. Roteiro cinematográfico: narrativa clássica, estudo e aplicação. 2010. Tese (Doutorado em Ciências da Comunicação) - CRT-ECA-USP. Universidade de São Paulo, São Paulo, 2010.

DEBORD, Guy. A sociedade do espetáculo. Rio de Janeiro: Contraponto, 2002.

DELEUZE, Gilles. Para além da imagem-movimento. In: Cinema 2: A imagemtempo. São Paulo: Brasiliense, 1990.

Cinema 1: a imagem-movimento. São Paulo: Brasiliense, 1985.

FELDMAN, Ilana. O apelo realista. FAMECOS, Porto Alegre, nº 36, 2008.

HAMBURGER, Esther. Visibilidade, visualidade e performance em 11 de setembro de 2011. In: BRASIL, André; MORETTIN, Eduardo; LISSOVSKY, Maurício. Visualidades Hoje. Salvador: EDUFBA, 2013.

Políticas de Representação - Ficção e Documentários em Ônibus 174. In: MOURÃO, Dora; LABAKI, Amir. O cinema do real. São Paulo: Cosac Naify, 2005.

HIKIJI, Rose. Imagem-Violência: mímesis e reflexividade em alguns filmes recentes. 1998. Dissertação (Mestrado em Antropologia) - PPGAS-FFLCH. Universidade de São Paulo, São Paulo, 1999. 
JAGUARIBE, Beatriz. O choque do real: estética, mídia e cultura. Rio de Janeiro: Rocco, 2007.

JORGE, Luís Antônio. O desenho da janela. São Paulo: Annablume, 1995.

KANT DE LIMA, Roberto; MISSE, Michel; MIRANDA, Ana Paula. Violência, Criminalidade, Segurança Pública e Justiça no Brasil: uma bibliografia. Revista Brasileira de Informação Bibliográfica em Ciências Sociais, Rio de Janeiro, nº 50, 2007.

KAWAKAMI, Tatiana. Toque de recolher do PCC: do boato na web às telas da tv. 2009. Dissertação (Mestrado em Comunicação) - Faculdade Cásper Líbero, São Paulo, 2009.

KEHL, Maria Rita. Radicais, Raciais, Racionais: a grande fratria do rap na periferia de São Paulo. São Paulo em Perspectiva [online], 1999.

MACHADO, Jr., Rubens L. R. O Pátio e o cinema experimental no Brasil: apontamentos para uma história. In: CASTELO, Branco \& ALENCAR, Edwar. História, cinema e outras imagens juvenis. Teresina: EDUFPI, 2009.

São Paulo, uma imagem que não pára. Revista D'Art, São Paulo, nº 9/10, 2002.

MACHADO, Roberto. Deleuze e a crise do cinema clássico. In: PESSOA, Fernando; BARBOSA, Ronaldo. Do abismo às montanhas. Vitória: Fundação Vale, 2010.

MARICATO, Ermínia. As testemunhas da cidade oculta: Racionais MC. In: Metrópole na periferia do capitalismo - ilegalidade, desigualdade e violência. São Paulo: Hucitec, 1996.

MARQUES, Adalton. 'Liderança', 'proceder' e 'igualdade': uma etnografia das relações políticas no Primeiro Comando da Capital. Etnográfica, Lisboa, v. 14, 2010.

McARTHUR, Colin. O filme policial. Lisboa: Horizonte, 1990. 
MITRY, Jean. Futurismo, expressionismo y cine. In: Historia del cine experimental.

Valencia: Fernando Torres, 1974.

NAGIB, Lúcia A utopia no cinema brasileiro: matrizes, nostalgia, distopias. São Paulo: Cosac Naify, 2006.

A língua da bala - realismo e violência em Cidade de Deus. Novos Estudos, São Paulo, v. 67, 2003.

NICHOLS, Bill. A voz do documentário. In: RAMOS, Fernão. Teoria Contemporânea do Cinema: Documentário e Narratividade Ficcional. São Paulo: Senac, 2005.

Representing Reality: Issues and Concepts in Documentary. Bloomington: Indiana University Press, 1991.

NODARI, Sandra. PCC: espetáculos promovidos nos horários de exibição dos telejornais. Revista AV-Audiovisual, São Leopoldo, v. 5, 2005.

ORICCHIO, Luiz Zanin. Cinema de novo: um balanço crítico da retomada. São Paulo: Estação Liberdade, 2003.

RAMOS, Fernão. Cinema e Realidade: alguns aspectos estruturais da imagem-câmera e sua particular intensidade. In: XAVIER, Ismail. O cinema do Século. Rio de Janeiro: Imago, 1996.

REZENDE, Sérgio \& ANDRADE, Patrícia. Salve Geral. São Paulo: Imprensa Oficial, 2009.

ROLNIK, Raquel. São Paulo. São Paulo: Publifolha, 2001.

RONDELLI, Elizabeth. Imagens da violência - práticas discursivas. Tempo Social - revista 
de sociologia, São Paulo, v. 10, 1998.

Media, representações sociais da violência, da criminalidade e ações políticas.

Comunicação \& Política, Rio de Janeiro, v.1, nº 2, 1995.

SALLES, João Moreira. Imagens em conflito. In: MOURÃO, Dora; LABAKI, Amir. O cinema do real. São Paulo: Cosac Naify, 2005.

STAM, Robert. The Carandiru massacre: across the mediatic spectrum.In:ANDERMANN, Jeans; BRAVO, Álvaro. New Argentine and Brazilian Cinema - reality effects. Nova Iorque: Palgrave Macmillan, 2013.

TAUSSIG, Michael. Xamanismo, colonialismo e o homem selvagem: um estudo sobre o terror e a cura. Rio de Janeiro: Paz e Terra, 1993.

TURIM, Maureen. Flashbacks in Film: memory \& history. Edition. New York: Routledge, 1989.

VEYNE, Paul. Como se escreve a história. Lisboa: Edições 70, 1983.

VIEIRA, João Luiz. O cinema provocação de Sérgio Bianchi. Programadora Brasil, Rio de Janeiro, $\mathrm{n}^{\mathrm{o}}$ 2, 2008

WAISELFISZ, Jacobo. Mapa da Violência II: os jovens do Brasil - juventude, violência e cidadania. Brasília: Unesco, 2000.

WINSTON, Brian. A maldição do 'jornalístico' na era digital. In: MOURÃO, Dora; LABAKI, Amir. O cinema do real. São Paulo: Cosac Naify, 2005.

XAVIER, Ismail. Corrosão Social, Pragmatismo e Ressentimento. Novos Estudos, São Paulo, v. 76, 2006 a. 
São Paulo no cinema: da coesão da cidade-máquina à corrosão da cidadearquipélago. Sinopse: Revista de Cinema, São Paulo, v. 11, 2006b.

O discurso cinematográfico: a opacidade e a transparência. São Paulo: Paz e Terra, 2005.

O olhar e a cena: melodrama, Hollywood, Cinema Novo, Nelson Rodrigues. São Paulo: Cosac Naify, 2003.

ZALUAR, Alba. Paradoxos do crime-negócio global no Brasil. In: FLEURY, Sonia; SUBIRATS, Joan; BLANCO, Ismael. Respostas locais a insegurança globais: inovação e mudança no Brasil e Espanha. Barcelona: CIDOB, 2008.

Trabalhadores e bandidos: identidade e discriminação. In: A máquina $\mathrm{e}$ a revolta: as organizações populares e o significado da pobreza. São Paulo: Brasiliense, 2000 .

. Violência e crime. In: MICELI, Sérgio. O que ler na Ciência Social brasileira (1970 - 1995). São Paulo: Editora Sumaré/ANPOCS, 1999.

\section{Filmes Citados}

5x Pacificação, Wagner Novais, Luciano Vidigal, Cadu Barcellos, 2012.

Alemão, José Eduardo Belmonte, 2014.

Ato dos homens, Kiko Goifman, 2006.

Antônia, Tata Amaral, 2006.

Bróder, Jeferson De, 2012. 
Carandirú, Hector Babenco, 2003.

Cidade de Deus, Fernando Meirelles , 2002.

Cidade Oculta, Chico Botelho, 1986.

Como Nascem os Anjos, Murilo Salles, 1997.

Contra Todos, Roberto Moreira, 2004.

Cronicamente Inviável, Sérgio Bianchi, 2010.

De Passagem, Ricardo Elias, 2003.

Dois Coelhos, Afonso Poyart, 2012.

Eles não usam black tie, Leon Hirszman, 1981.

Janela Indiscreta, Alfred Hitchcock, 1954.

Linha de Passe, Walter Salles e Daniela Thomas, 2008.

Máquina Mortifera, Richard Donner, 1987.

Mato Eles?, Sérgio Bianchi, 1983.

Notícias de uma guerra particular, João Moreira Salles, 1999.

O Bandido da Luz Vermelha, Rogério Sganzerla, 1968.

O gabinete do Doutor Caligari, Robert Wiene, 1920.

O Grande Momento, Roberto Santos, 1957.

O Invasor, Beto Branti, 2001.

O som ao redor, Kleber Mendonça Filho, 2012. 
Onde São Paulo Acaba, Andréa Seligmann, 1995.

Onibus 174, José Padilha, 2002.

Os 12 trabalhos, Ricardo Elias, 2007.

Os Fuzis, Rui Guerra, 1964.

Pierrot le fou, Jean-Luc Godard, 1965.

Psicose, Alfred Hitchcock, 1960.

São Paulo S.A., Luís Sérgio Person, 1965.

São Paulo Sinfonia da Metrópole, Kemeny \& Lustig, 1929.

Se Deus vier que venha armado, Luís Augusto Dantas, 2013.

Tropa de Elite 2: o inimigo agora é outro, José Padilha, 2010.

Tropa de Elite, José Padilha, 2007.

Última Parada 174, Bruno Barreto, 2008.

Um corpo que cai [Vertigo], Alfred Hitchcock, 1958. 


\title{
Referência completa dos filmes analisados
}

\author{
OS INQUILINOS - os incomodados que se mudem
}

Ano: 2009

Direção: Sérgio Bianchi

Roteiro: Sérgio Bianchi e Beatriz Bracher

Fotografia: Marcelo Corpanni

Direção de Arte: Bia Pessoa

Montagem: André Finotti

Técnico de Som: Paulo Ricardo

Montagem de Som: Ricardo Reis e Miriam Bidermam

Produção executiva: Sérgio Bianchi

Produtora: Agravo Produções Cinematográficas

Distribuição: Pandora Filmes

INVERSÃO

Ano: 2010

Direção: Edu Felistoque

Roteiro: Edu Felistoque e Maurício Fernandes

Fotografia: Caco Souza

Direção de Arte: Renata Rugai

Montagem: Conrado Pera, George Queiróz, Dirk Boll

Direção Musical: Diogo Poças

Som Direto: Jorge Vaz

Sonografia: Emerson Bueno 
Montagem de Som: Espósito, Mauricio e Gaspar, Francisco

Música Original: Túlio Dek, Nuggs, Diogo Poças, Aldo Paranga e Samuel

Direção de Produção: Zeca Paixão

Produção: Edu Felistoque e Adone Fragano

Produção executiva: Adone Fragano

Produtoras: Olympus Filme Ltda e Felistoque Filmes Ltda.

Distribuição: California Filmes

\section{SALVE GERAL}

Ano: 2009

Direção: Sérgio Rezende

Roteiro: Sérgio Rezende e Patricia Andrade

Fotografia: Uli Burtin

Direção de Arte: Vera Hamburger

Montagem: Marcelo Moraes

Direção musical e trilha original: Miguel Briamonte

Som direto: Márcio Câmara

Mixagem: Rodrigo Noronha

Efeitos especiais de som: Felipe Burger Marques

Montagem de Som: Waldir Xavier

Direção de produção: Montenegro, André

Produção: Joaquim Vaz de Carvalho e Laís Chamma

Produção executiva: Heloisa Rezende

Produtora: Toscana Audiovisual

Co-Produtora: Globo Filmes

Distribuição: Downtown Filmes; Sony Pictures 


\section{Anexo}

Representação da locação

central de Inquilinos (sem escala)
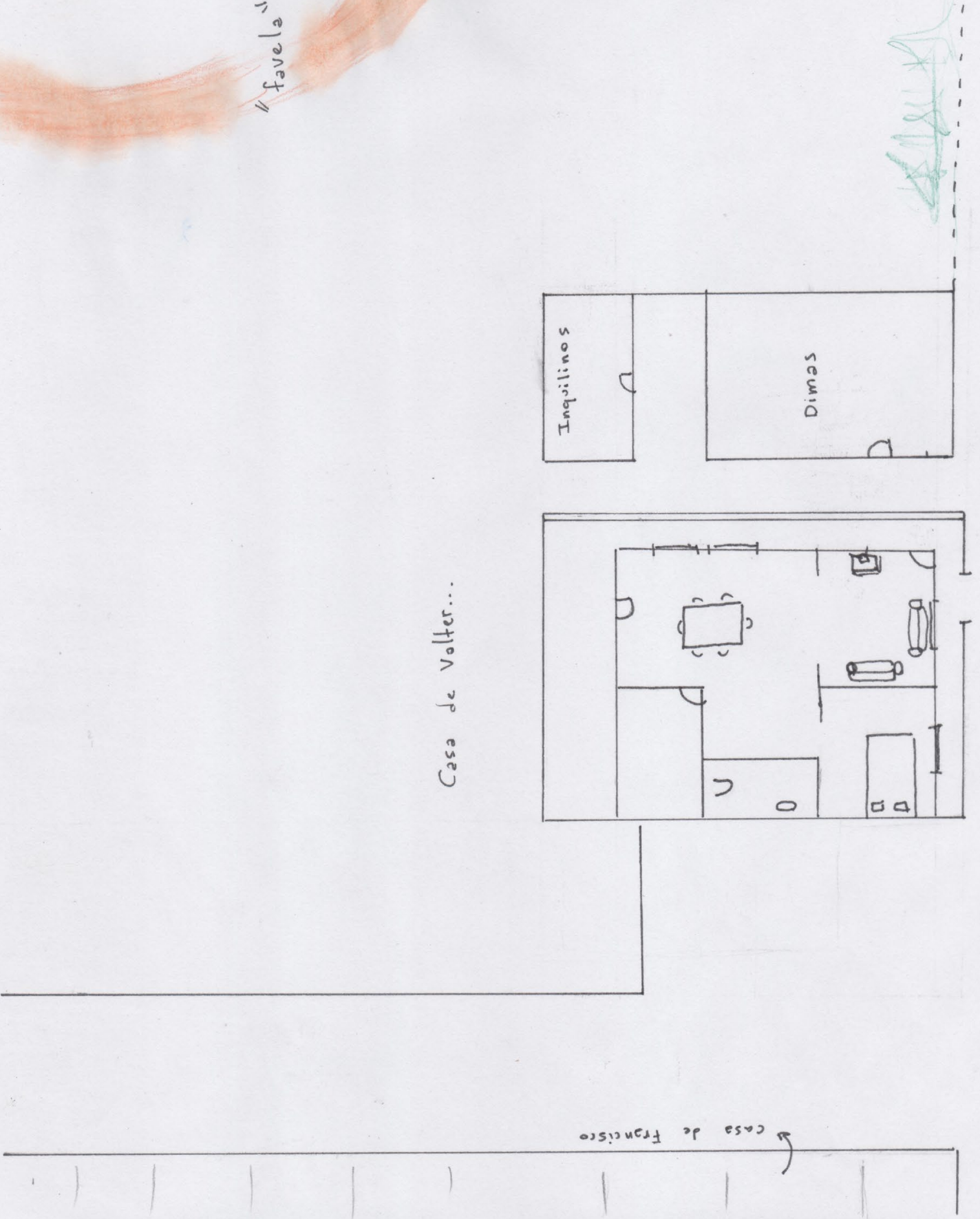